\title{
Preparation of mono- and diisocyanates in flow from renewable carboxylic acids
}

\section{Supporting Information}

Thien An Phung Hai ${ }^{\mathrm{a}}$, Laurent J. S. De Backer ${ }^{\mathrm{b}}$, Nicholas D. P. Cosford ${ }^{\mathrm{b}}$ and Michael D. Burkart ${ }^{\mathrm{ac} *}$

${ }^{a}$ Department of Chemistry and Biochemistry, University of California, San Diego, 9500 Gilman Drive, La Jolla, CA 92093-0358, USA.

${ }^{\mathrm{b}}$ Cancer Metabolism \& Signaling Networks Program, NCI-Designated Cancer Center, Sanford-BurnhamPrebys Medical Discovery Institute, 10901 North Torrey Pines Road, La Jolla, CA 92037, USA.

${ }^{\mathrm{c}}$ The California Center for Algae Biotechnology, University of California San Diego, 9500 Gilman Drive MC 0368, La Jolla, CA 92093, USA.

\section{Table of Contents}

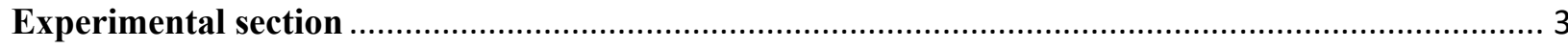

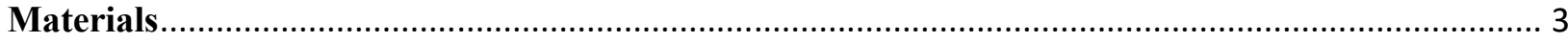

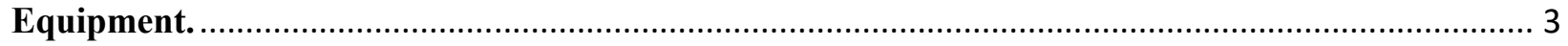

Synthesis of Azelaic acid and Heptanoic acid from algae oil ....................................................... 3

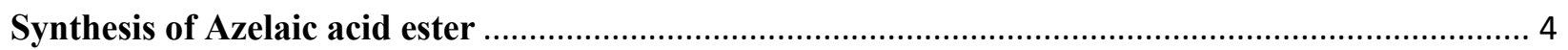

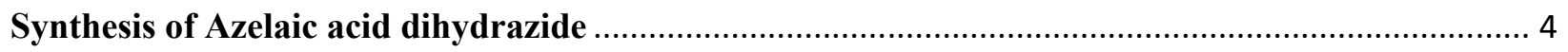

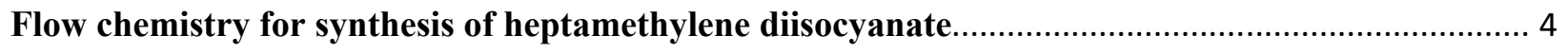

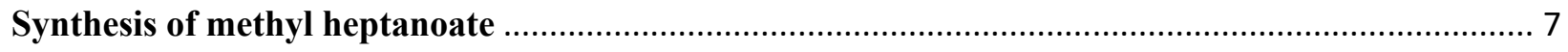

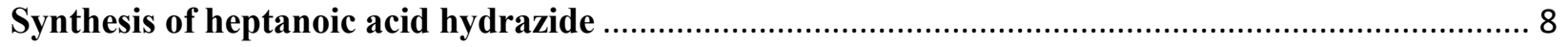

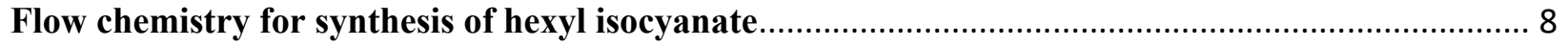

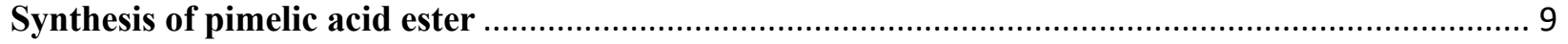

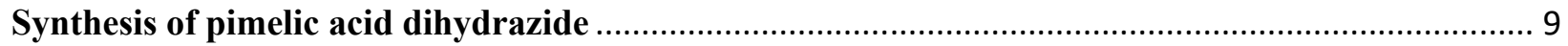

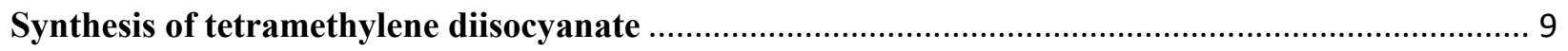

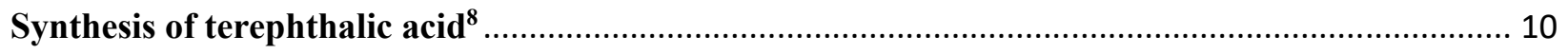

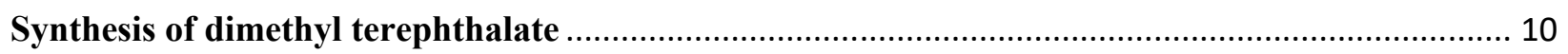

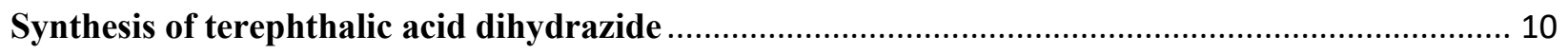

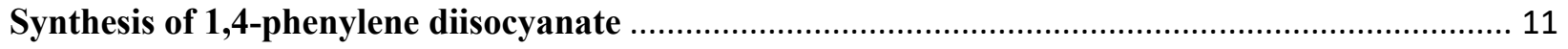

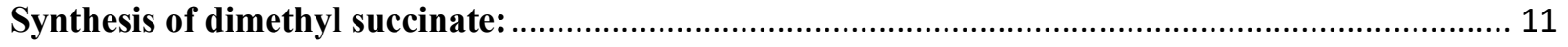

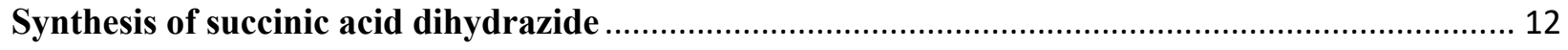

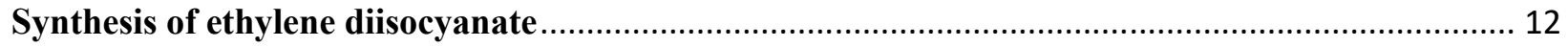

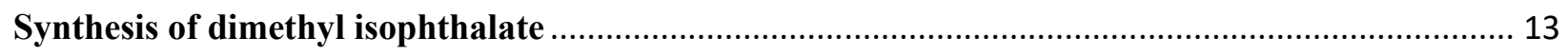

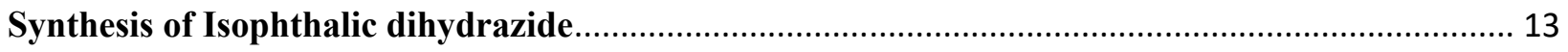




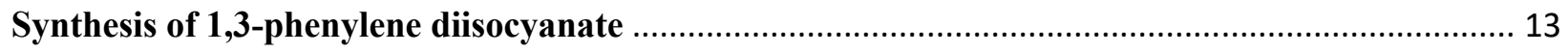

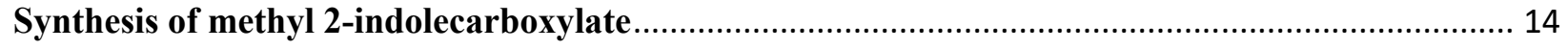

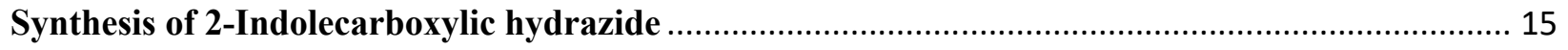

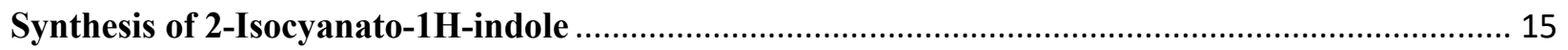

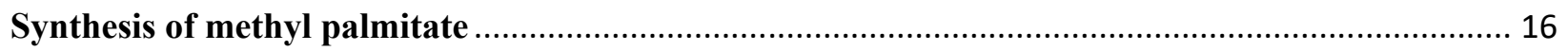

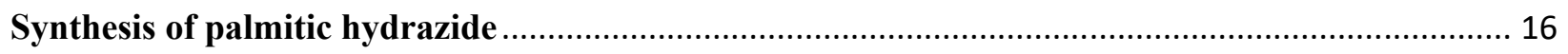

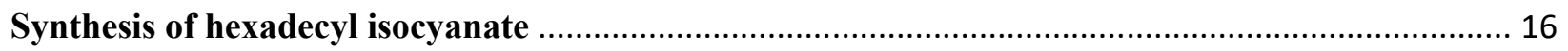

Synthesis of 2-ethylhexanoic acid methyl ester: ..................................................................... 17

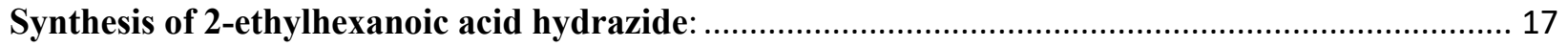

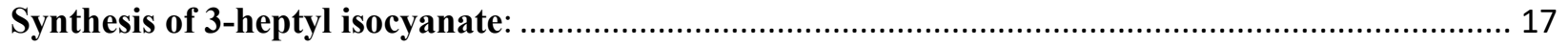

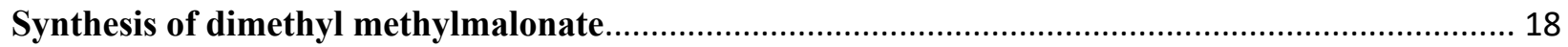

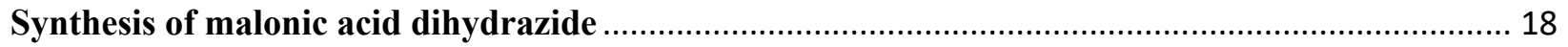

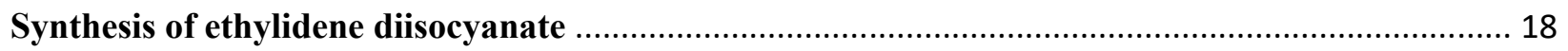

Synthesis of 5-methylisophthalic acid dimethyl ester ................................................................ 19

Synthesis of 1,3-Benzenedicarboxylic acid, 5-methyl-,1,3-dihydrazide .......................................... 19

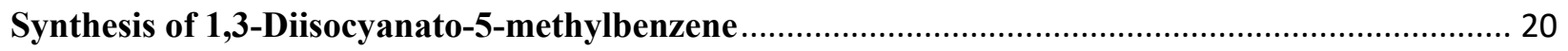

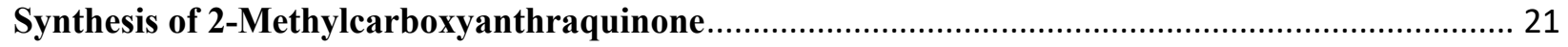

Synthesis of 2-Anthraquinonecarboxylic acid hydrazide ............................................................ 21

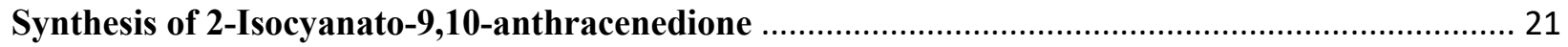

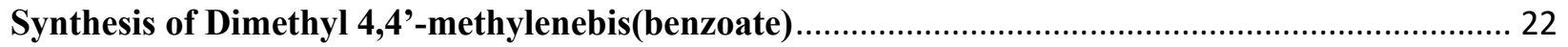

Synthesis of Benzoic acid 4,4'-methylenedi-dihydrazide ............................................................... 22

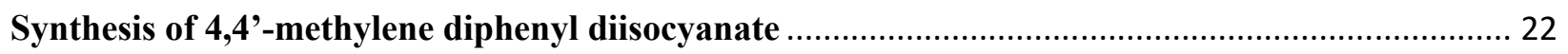

Synthesis of 3,3-dimethyl-1,2-cyclopropanedicarboxylic acid: .................................................. 23

Synthesis of 3,3-dimethyl-1,2-cyclopropanedicarboxylic acid-1,2-dimethyl ester: ........................ 24

Synthesis of 1,2-cyclopropanedicarboxylic acid-3,3-dimethyl-1,2-dihydrazide ............................. 24

Synthesis of cyclopropane-2,3-diisocyanato-1,1-dimethyl:........................................................... 24

Synthesis of 2,5-furandicarboxylic acid, 2,5-dimethyl ester....................................................... 25

Synthesis of 2,5-furandicarboxylic acid, 2,5-dihydrazide............................................................ 25

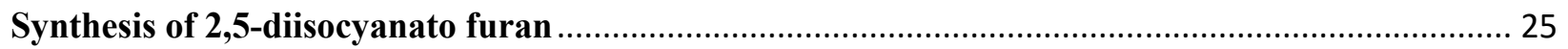

Synthesis of methyl adamantine-1-carboxylate: ....................................................................... 26

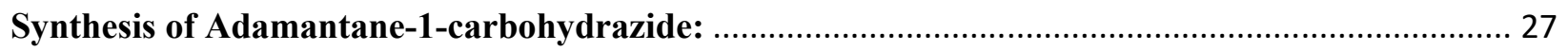

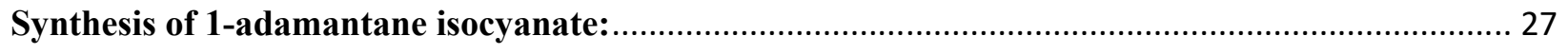

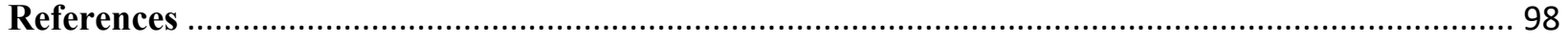




\title{
Experimental section
}

\begin{abstract}
Materials
Chemical reagents were purchased from Fisher Chemical, Macron Fine Chemicals, Sigma Aldrich, Acros, Fluka, Alfa Aesar Chemicals or TCI. All chemicals were regent grade and used without further purification. Analytical grade solvents such as acetone, hexane, acetonitrile, dichloromethane, ethanol and methanol were purchased from Fisher Chemical and used as received. Deuterated NMR solvents such as chloroformd, DMSO-d6 were purchased from Cambridge Isotope Laboratories.
\end{abstract}

\section{Equipment.}

Gas chromatography mass spectrometry (GC-MS) was measured using an Agilent 7890A GC system connected to a 5975C VL MSD quadrupole MS (EI). Samples were separated on a 60m DB23 Agilent GCMS column using helium as carrier gas and a gradient of $110^{\circ} \mathrm{C}$ to $200{ }^{\circ} \mathrm{C}$ at $15^{\circ} \mathrm{Cmin}^{-1}$, followed by 20 minutes at $200{ }^{\circ} \mathrm{C} .{ }^{1} \mathrm{H}$ NMR and ${ }^{13} \mathrm{C}$ NMR spectra were recorded on a JOEL ECA 500 or a Varian VX500 spectrometer equipped with an Xsens Cold probe. ThermoFinnigan LCQ Deca spectrometer was used for Electrospray (ESI) mass spectrometric analyses while ThermoFinnigan MAT900XL mass spectrometer with electron impact (EI) ionization was used for high resolution analyses. High resolution electrospray ionization mass spectrometry analyses (HR-ESI-MS) were performed using a Thermo Scientific LTQ Orbitrap XL mass spectrometer. FT-IR was recorded on PerkinElmer FTIR. Ozonolysis is conducted in batch mode with the Triogen LAB2B Ozone generator. Flow chemistry system is constructed and assembled from four different parts: building syringe pumps, connecting the electronics, designing and connecting the tubing and Arduino code options. This system is set up followed the instruction and reference from Croatt Research group (University of North Carolina at Greensboro). All information can be accessed following this link: chem.uncg.edu/croatt/flow-chemistry/. To perform the studies described herein we constructed a flow system analogous to those from the Croatt Research group. For this set up system, it is possible to modify variable power supplies for stepper motors with a higher torque rating, a necessity for varying syringe volumes. Moreover, the instruction for installing Zaiput separator and drying unit can be referenced from followed paper. ${ }^{1}$ Continuous flow experiments were carried out using a Vapourtec R Series Flow Chemistry system ${ }^{2,3}$ for scaling up products.

\section{Synthesis of Azelaic acid and Heptanoic acid from algae oil}

Preparing according to methods previously reported by our lab ${ }^{4}$ including purification of fatty acids from biomass, pigment removal, isolation of mono-unsaturated fatty acid C16-1, and oxidative cleavage of C161 to synthesize azelaic acid and heptanoic acid.

Azelaic acid: ${ }^{1} \mathrm{H}$ NMR (500 MHz, DMSO- $\left.d_{6}\right) \delta=11.95(\mathrm{~s}, 1 \mathrm{H}), 2.15(\mathrm{t}, J=7.3,2 \mathrm{H}), 1.44(\mathrm{p}, J=7.1,2 \mathrm{H})$, $1.21(\mathrm{~d}, J=6.5,3 \mathrm{H}) ;{ }^{13} \mathrm{C}$ NMR $\left(126 \mathrm{MHz}, \mathrm{DMSO}-d_{6}\right) \delta=175.10,34.16,28.95,24.97$; HR-ESI-MS calcd. for $\mathrm{C}_{9} \mathrm{H}_{16} \mathrm{O}_{4}[\mathrm{M}-\mathrm{H}]:$ : 187.22 , found 187.25

Heptanoic acid: ${ }^{1} \mathrm{H}$ NMR $\left(500 \mathrm{MHz}, \mathrm{DMSO}-d_{6}\right) \delta=11.92(\mathrm{~s}, 1 \mathrm{H}), 2.14(\mathrm{t}, J=7.3,2 \mathrm{H}), 1.44(\mathrm{q}, J=7.1,2 \mathrm{H})$, $1.27-1.18(\mathrm{~m}, 7 \mathrm{H}), 0.85-0.79(\mathrm{~m}, 2 \mathrm{H}) ;{ }^{13} \mathrm{C}$ NMR $\left(126 \mathrm{MHz}, \mathrm{DMSO}-d_{6}\right) \delta=175.17,34.18,31.48,29.53$, 28.72, 24.97, 22.49, 14.38; HR-ESI-MS calcd. for $\mathrm{C}_{7} \mathrm{H}_{14} \mathrm{O}_{2}[\mathrm{M}-\mathrm{H}]=:$ : 29.18 , found 129.23 


\section{Synthesis of Azelaic acid ester}

Azelaic acid $(20 \mathrm{~g}, 0.1 \mathrm{~mol})$ was added to a $250 \mathrm{~mL}$ one-neck round-bottom flask, then $86 \mathrm{~mL}$ methanolic $\mathrm{HCl} 1 \mathrm{M}$ was poured into this flask ${ }^{5}$. The reaction was reflux for $2 \mathrm{~h}$ at temperature of $80^{\circ} \mathrm{C}$. Once finishing reaction, $100 \mathrm{~mL}$ hexane was added to the flask. Two layers were divided by separating funnel. The hexane layer on top was collected, dried over anhydrous $\mathrm{Na}_{2} \mathrm{SO}_{4}$, and removed solvent to obtain azelaic acid ester as a colorless oil with the yield of $82 \%$.

Dimethyl azelate: ${ }^{1} \mathrm{H}$ NMR (500 MHz, Chloroform- $d$ ) $\delta=3.64(\mathrm{~s}, 3 \mathrm{H}), 2.28(\mathrm{t}, J=7.5,2 \mathrm{H}), 1.59(\mathrm{t}, J=7.2$, $2 \mathrm{H}), 1.29(\mathrm{~s}, 2 \mathrm{H}), 1.33-1.22(\mathrm{~m}, 1 \mathrm{H})$.

\section{Synthesis of Azelaic acid dihydrazide}

$14.5 \mathrm{~mL} \mathrm{~N}_{2} \mathrm{H}_{4}(0.5 \mathrm{~mol})$ was added slowly to $80 \mathrm{~mL}$ methanol containing $10 \mathrm{~g}$ azelaic acid ester $(0.05 \mathrm{~mol})$ in $150 \mathrm{~mL}$ one-neck round-bottom flask ${ }^{5-7}$. A white slurry was observed after refluxing the mixture for $6 \mathrm{~h}$ at a temperature of $90^{\circ} \mathrm{C}$. Azelaic acid dihydrazide ( $88 \%$ in yield) appeared as a white powder was collected after filtration and washing with methanol.

Azelaic acid dihydrazide: ${ }^{1} \mathrm{H}$ NMR $\left(500 \mathrm{MHz}, \mathrm{DMSO}-d_{6}\right) \delta=8.88(\mathrm{~s}, 1 \mathrm{H}), 4.13(\mathrm{~s}, 2 \mathrm{H}), 1.95(\mathrm{t}, J=7.4,2 \mathrm{H})$, 1.42 (p, $J=7.2,6.7,2 \mathrm{H}), 1.18(\mathrm{~s}, 3 \mathrm{H}), 1.15(\mathrm{~d}, J=7.5,1 \mathrm{H}) ;{ }^{13} \mathrm{C}$ NMR $\left(126 \mathrm{MHz}, \mathrm{DMSO}-d_{6}\right) \delta=25.73,31.24$, 33.93, 172.15; HR-ESI-MS calcd. for $\mathrm{C}_{9} \mathrm{H}_{20} \mathrm{~N}_{4} \mathrm{O}_{2}[\mathrm{M}+\mathrm{H}]^{+}: 217.28$, found 217.16

\section{Flow chemistry for synthesis of heptamethylene diisocyanate}

The flow system in our work was set up as described in Figure S1.

Solution 1: sodium nitrite $(1.37 \mathrm{~g}, 0.02 \mathrm{~mol})$ was distilled into $100 \mathrm{~mL}$ deionized water. The concentration was $0.2 \mathrm{M}$

Solution 2: pure toluene

Solution 3: azelaic dihydrazide $(2.16 \mathrm{~g}, 0.01 \mathrm{~mol})$ was dissolved in $100 \mathrm{~mL}$ deionized water and $0.8 \mathrm{~mL}$ conc. $\mathrm{HCl}$. The concentration was $0.1 \mathrm{M}$.

All solutions were pumped with a flow rate of $1 \mathrm{~mL} \mathrm{~min}^{-1}$. The $1.62 \mathrm{~mL}$ coiled reactor was cooled down to $5-10^{\circ} \mathrm{C}$ in a cold bath, resulting in a residence time of $97 \mathrm{~s}$. The outlet then entered the Zaiput separator, which provides continuous separation of the two immiscible liquids, toluene and water. After complete separation, water exited on one side and was collected in a waste Erlenmeyer flask while the organic phase exited on the other side. The organic phase containing the azide product was directly sent to the drying unit with anhydrous sodium sulfate to remove trace water. Finally, the outlet was injected into a second 5 $\mathrm{mL}$ coiled reactor, which was heated to $85^{\circ} \mathrm{C}$ in a sand bath. The outlet containing heptamethylene diisocyanate product was placed in an Erlenmeyer flask. After removing solvent, heptamethylene diisocyanate was collected as a pale-yellow liquid and stored at a temperature of $4{ }^{\circ} \mathrm{C}$. This system provides heptamethylene diisocyanate at a rate of $500 \mathrm{mg} \mathrm{h}^{-1}$.

Heptamethylene diisocyanate: ${ }^{1} \mathrm{H}$ NMR $(500 \mathrm{MHz}$, Chloroform- $d$ ) $\delta=3.29(\mathrm{t}, J=6.6,5 \mathrm{H}), 2.21(\mathrm{t}, J=7.5$, $0 \mathrm{H}), 1.60(\mathrm{~h}, J=6.1,6 \mathrm{H}), 1.44-1.27(\mathrm{~m}, 7 \mathrm{H}) ;{ }^{13} \mathrm{C}$ NMR $(126 \mathrm{MHz}$, Chloroform- $d) \delta=138.02,129.21$, $128.40,125.47,122.13,43.05,31.33,31.29,28.49$, 26.55, 21.60; HR-ESI-MS calcd. for $\mathrm{C}_{9} \mathrm{H}_{14} \mathrm{~N}_{2} \mathrm{O}_{2}$ $[\mathrm{M}+\mathrm{H}]^{+}: 183.23$, found 183.07 


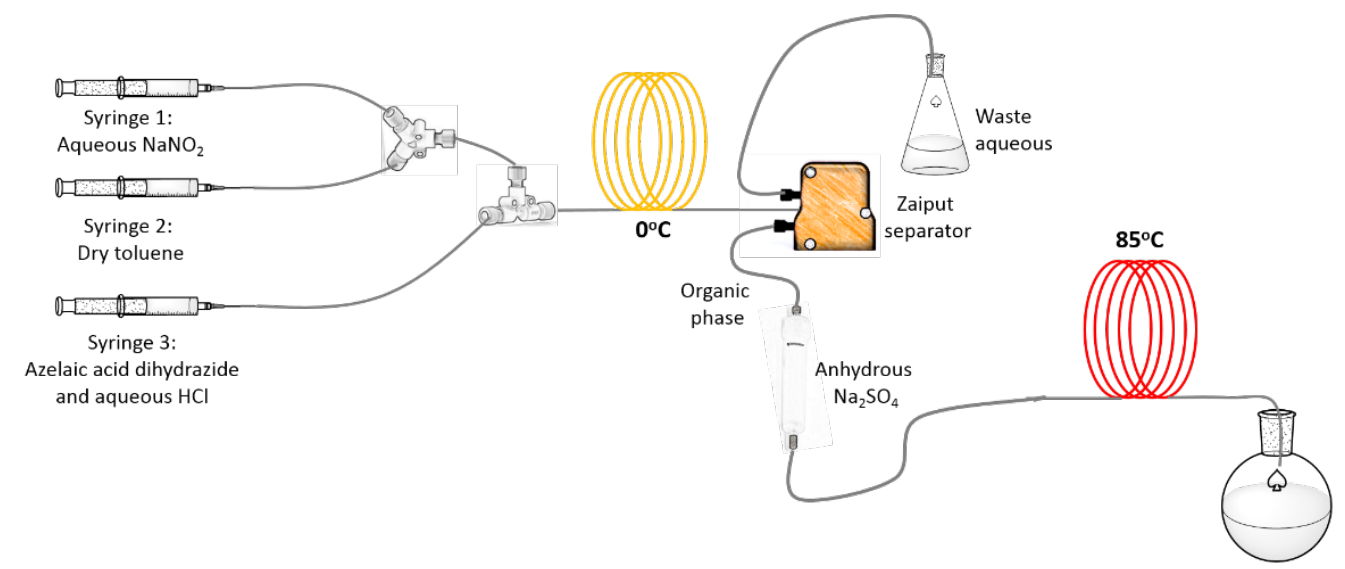

Figure S1. The chart of flow synthesis of heptamethylene diisocyanate

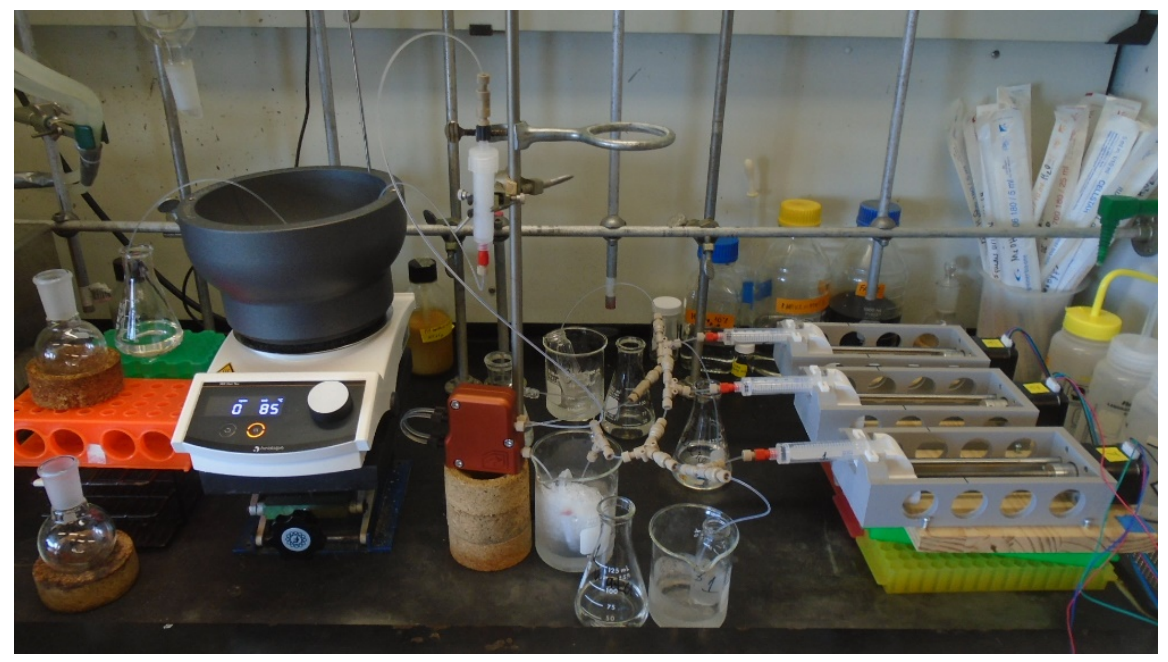

(2A) Setup for the flow system

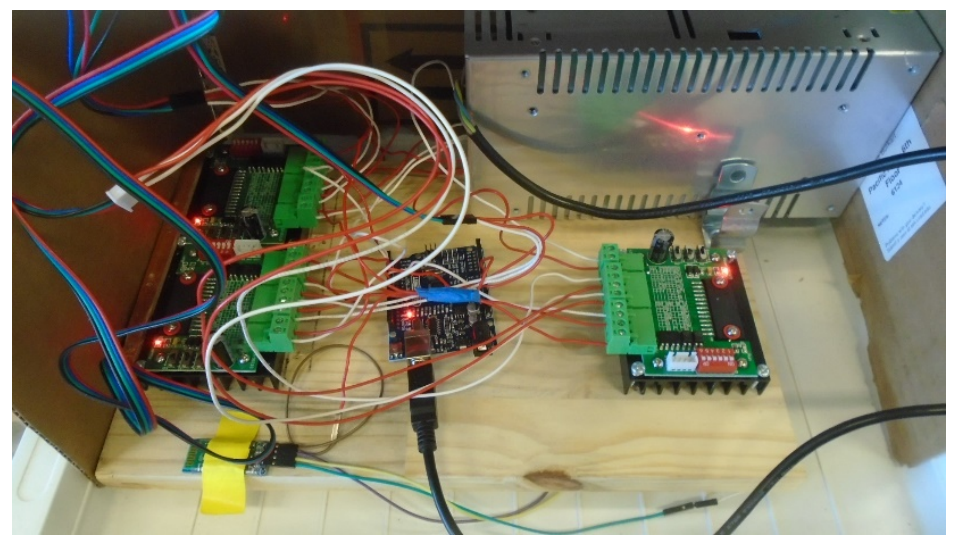

(2B) Electronic connection including stepper motor, power supply unit, Arduino, and motor controller

Figure S2. Flow chemistry system with 3 syringe pumps controlled by Arduino 


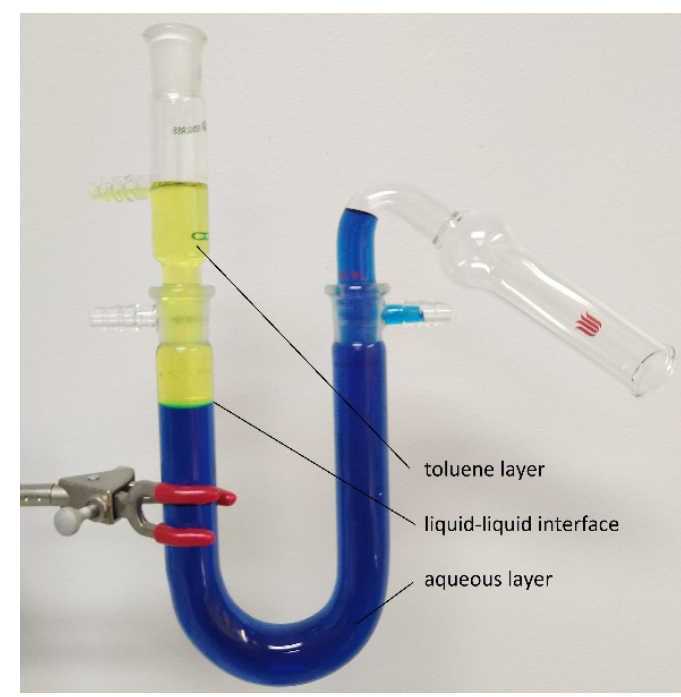

Figure S3. Liquid-liquid separator in scaleup (Vapourtec) flow system

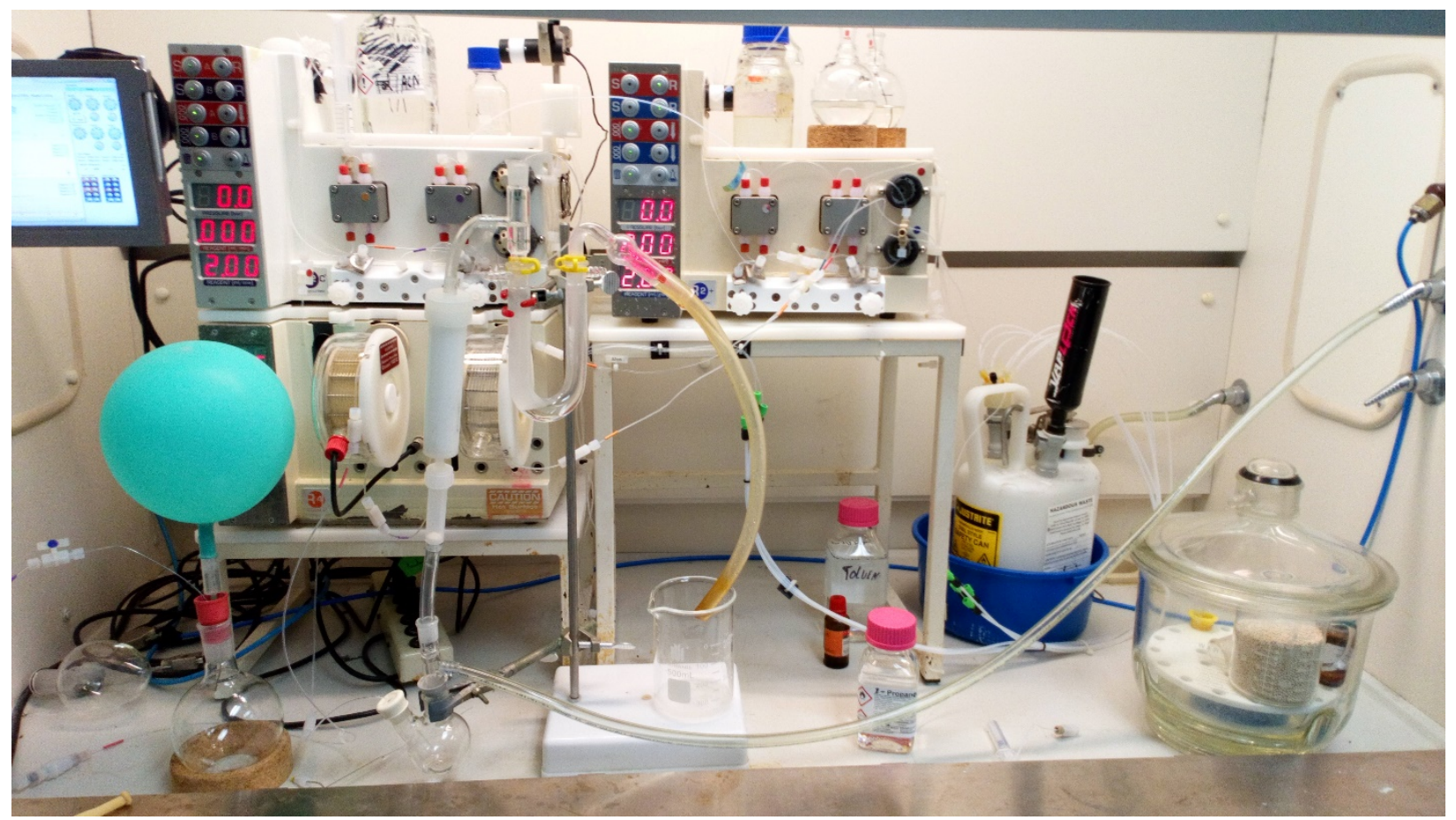

Figure S4. Vapourtec R-series flow apparatus for large-scale production 


\section{Mono-carboxylic acid}
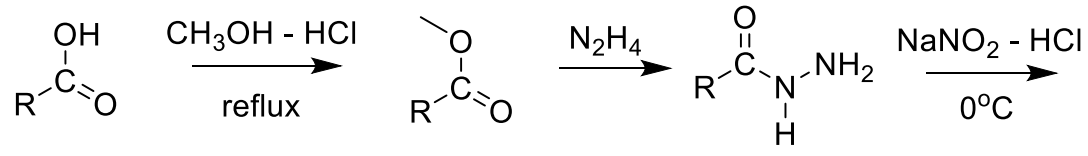

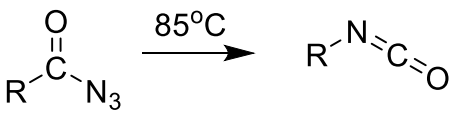

Di-carboxylic acid

not isolated

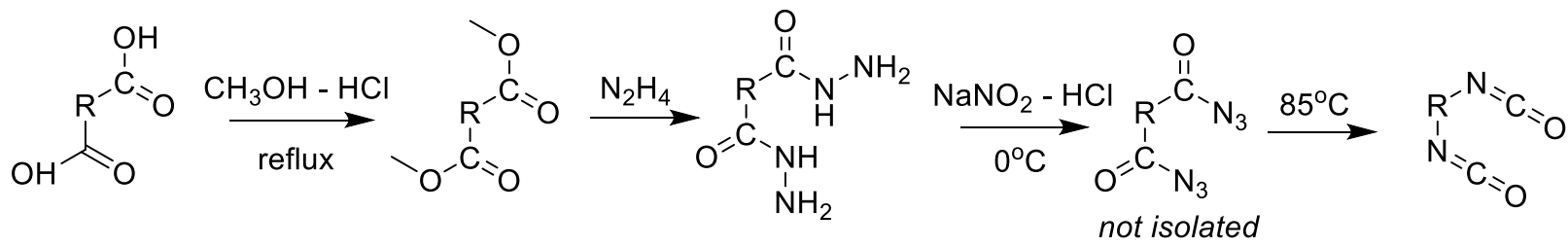

Figure S5. The pathway for isocyanate derivatives synthesis from mono/di carboxylic acid
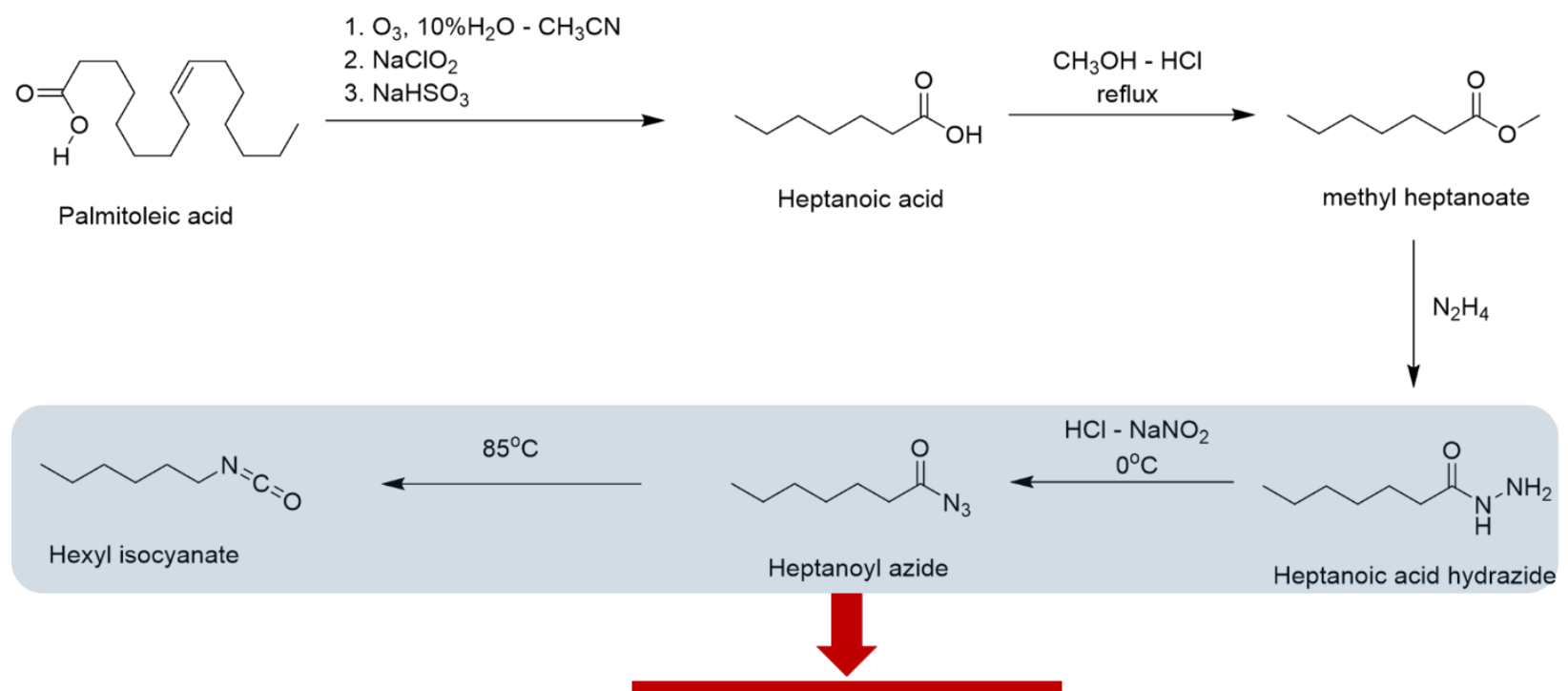

\section{process in continuous flow system}

Figure S6: Pathway to synthesize hexyl isocyanate from heptanoic acid originating from algae oil (Table 1 , entry 4)

\section{Synthesis of methyl heptanoate}

Heptanoic acid $(20 \mathrm{~g}, 0.15 \mathrm{~mol})$ was added to a $250 \mathrm{~mL}$ one-neck round-bottom flask, then $125 \mathrm{~mL}$ methanolic $\mathrm{HCl} 1 \mathrm{M}$ was poured into this flask. The reaction was reflux for $2 \mathrm{~h}$. Once finishing reaction, 100 $\mathrm{mL}$ hexane was added to the flask. After separation by funnel, the organic layer was dried over anhydrous $\mathrm{Na}_{2} \mathrm{SO}_{4}$, and evaporated to afford azelaic acid ester as a colorless liquid with the yield of $85 \%$.

Methyl heptanoate: ${ }^{1} \mathrm{H}$ NMR $(500 \mathrm{MHz}$, Chloroform- $d$ ) $\delta=3.64(\mathrm{~s}, 3 \mathrm{H}), 2.31-2.25(\mathrm{~m}, 2 \mathrm{H}), 1.59(\mathrm{t}, J=7.3$, $2 \mathrm{H}), 1.34-1.21(\mathrm{~m}, 12 \mathrm{H}), 0.90-0.81(\mathrm{~m}, 4 \mathrm{H})$. 


\section{Synthesis of heptanoic acid hydrazide}

The methyl heptanoate $(10 \mathrm{~g}, 0.06 \mathrm{~mol})$ was dispersed in a mixture of methanol $(140 \mathrm{~mL})$ and hydrazine monohydrate $(21 \mathrm{~mL}, 0.6 \mathrm{~mol})^{5-7}$. The reaction was refluxed for $6 \mathrm{~h}$. After cooling down, the product was precipitated and filtered off. The product was dried in vacuum after washing with water, as a white solid $(80 \%)$.

Heptanoic acid hydrazide: ${ }^{1} \mathrm{H}$ NMR $\left(500 \mathrm{MHz}, \mathrm{DMSO}-d_{6}\right) \delta=8.88(\mathrm{~s}, 1 \mathrm{H}), 4.03(\mathrm{~s}, 1 \mathrm{H}), 1.96(\mathrm{t}, J=7.4$, $2 \mathrm{H}), 1.43$ (p, $J=7.2,2 \mathrm{H}), 1.20(\mathrm{dtd}, J=12.6,8.6,8.0,4.6,6 \mathrm{H}), 0.82(\mathrm{t}, J=6.9,3 \mathrm{H}) ;{ }^{13} \mathrm{C}$ NMR $(126 \mathrm{MHz}$, DMSO- $\left.d_{6}\right) \delta=172.20,33.95,31.54,28.86,25.72,22.54,14.46$; HR-ESI-MS calcd. for $\mathrm{C}_{7} \mathrm{H}_{16} \mathrm{~N}_{2} \mathrm{O}[\mathrm{M}+\mathrm{H}]^{+}$: 145.21, found 145.18.

\section{Flow chemistry for synthesis of hexyl isocyanate}

The flow system in our work was set up as described in Figure S1.

Solution 1: sodium nitrite $(1.37 \mathrm{~g}, 0.02 \mathrm{~mol})$ was distilled into $100 \mathrm{~mL}$ deionized water. The concentration was $0.2 \mathrm{M}$

Solution 2: pure toluene

Solution 3: heptanoic acid hydrazide $(1.44 \mathrm{~g}, 0.01 \mathrm{~mol})$ was dissolved in $100 \mathrm{~mL}$ deionized water and 0.8 $\mathrm{mL}$ conc. $\mathrm{HCl}$. The concentration was $0.1 \mathrm{M}$.

All solutions were pumped with a flow rate of $1 \mathrm{~mL} \mathrm{~min}^{-1}$. The $1.62 \mathrm{~mL}$ coiled reactor was cooled down to $5-10^{\circ} \mathrm{C}$ in a cold bath, resulting in a residence time of $97 \mathrm{~s}$. The outlet then entered the Zaiput separator, which provides continuous separation of the two immiscible liquids, toluene and water. After complete separation, water exited on one side and was collected in a waste Erlenmeyer flask while the organic phase exited on the other side. The organic phase containing the azide product was directly sent to the drying unit with anhydrous sodium sulfate to remove trace water. Finally, the outlet was injected into a second 5 $\mathrm{mL}$ coiled reactor, which was heated to $85^{\circ} \mathrm{C}$ in a sand bath. The outlet containing hexyl isocyanate product was placed in an Erlenmeyer flask. After removing solvent, hexyl isocyanate was collected as a colorless liquid and stored at a temperature of $4{ }^{\circ} \mathrm{C}$. This system provides hexyl isocyanate at a rate of $500 \mathrm{mg} \mathrm{h}^{-1}$.

Hexyl isocyanate: ${ }^{1} \mathrm{H}$ NMR $(500 \mathrm{MHz}$, Chloroform- $d$ ) $\delta=7.29(\mathrm{t}, J=7.6,2 \mathrm{H}), 7.20(\mathrm{dd}, J=13.1,7.1,3 \mathrm{H})$, $3.30(\mathrm{t}, J=6.8,2 \mathrm{H}), 2.39(\mathrm{~s}, 3 \mathrm{H}), 1.64(\mathrm{~d}, J=14.8,1 \mathrm{H}), 1.46-1.28(\mathrm{~m}, 9 \mathrm{H}), 0.94(\mathrm{q}, J=6.3,5.9,4 \mathrm{H}) ;{ }^{13} \mathrm{C}$ NMR (126 MHz, Chloroform-d) $\delta=137.98,129.17,128.36,125.44,122.10,43.10,31.67,31.53,31.41$, $31.28,29.04,26.35,25.64,22.81,22.66,21.54,14.24,14.14,14.08$. HR-ESI-MS calcd. for $\mathrm{C}_{7} \mathrm{H}_{13} \mathrm{NO}$ $[\mathrm{M}+\mathrm{H}]^{+}: 128.18$, found 128.14

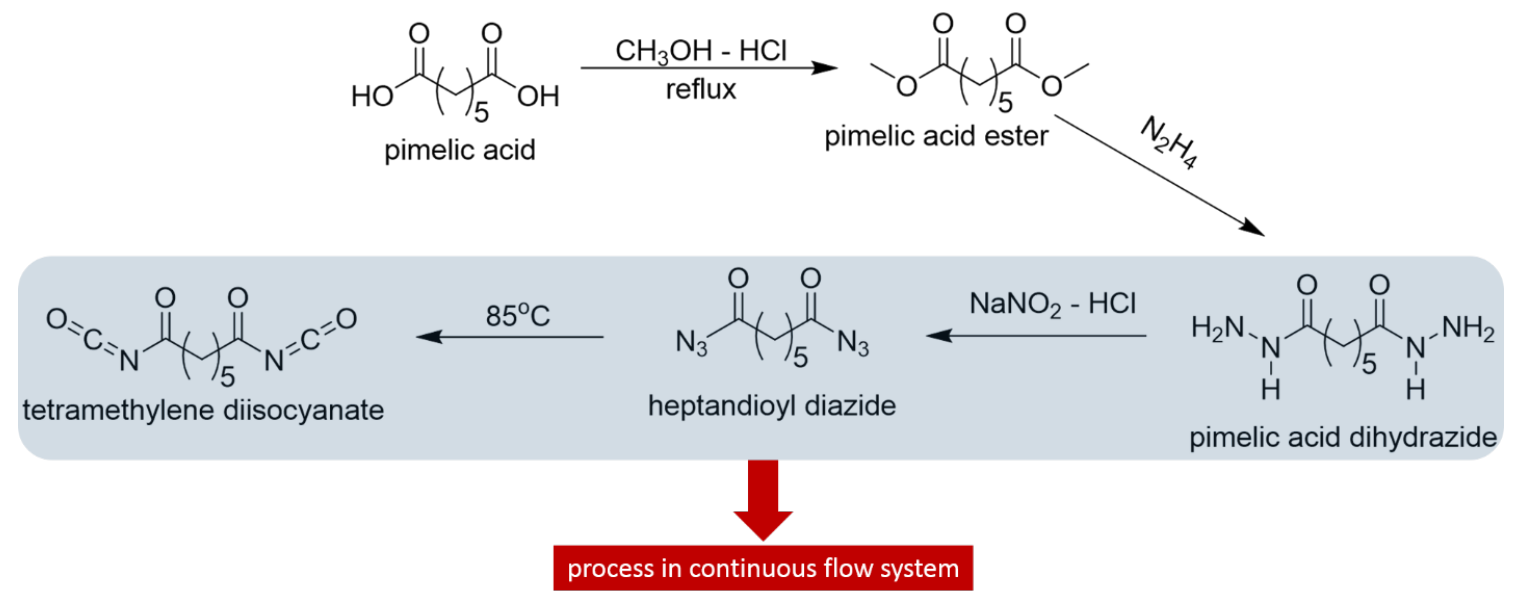

Figure S7: Pathway to synthesize tetramethylene diisocyante from pimelic acid (Table 1, entry 2) 


\section{Synthesis of pimelic acid ester}

Pimelic acid $(20 \mathrm{~g}, 0.13 \mathrm{~mol})$ was added to a $250 \mathrm{~mL}$ one-neck round-bottom flask, then $100 \mathrm{~mL}$ methanolic $\mathrm{HCl} 1 \mathrm{M}$ was poured into this flask. The reaction was reflux for $2 \mathrm{~h}^{5}$. Once finishing reaction, $100 \mathrm{~mL}$ hexane was added to the flask. Two layers were divided by separating funnel. The organic layer was dried over anhydrous $\mathrm{Na}_{2} \mathrm{SO}_{4}$, and evaporated to afford pimelic acid ester as a colorless oil with the yield of $82 \%$.

Pimelic acid ester: ${ }^{1} \mathrm{H}$ NMR (500 MHz, Chloroform- $d$ ) $\delta=3.62(\mathrm{~s}, 3 \mathrm{H}), 2.27$ (t, $\left.J=7.6,2 \mathrm{H}\right), 1.60$ (p, $J=7.4$, $2 \mathrm{H}), 1.36-1.26(\mathrm{~m}, 1 \mathrm{H})$.

\section{Synthesis of pimelic acid dihydrazide}

$16.5 \mathrm{~mL} \mathrm{~N}_{2} \mathrm{H}_{4}(0.5 \mathrm{~mol})$ was added slowly to $80 \mathrm{~mL}$ methanol contain $10 \mathrm{~g}$ pimelic acid ester $(0.05 \mathrm{~mol})$ in $150 \mathrm{~mL}$ one-neck round-bottom flask ${ }^{5-7}$. The reaction was refluxed for $6 \mathrm{~h}$. After cooling down, pimelic acid dihydrazide ( $88 \%$ in yield) is collected as a white powder after filtration and washing with methanol.

Pimelic acid dihydrazide: ${ }^{1} \mathrm{H}$ NMR $\left(500 \mathrm{MHz}, \mathrm{DMSO}-d_{6}\right) \delta=8.93(\mathrm{~s}, 1 \mathrm{H}), 4.12(\mathrm{~s}, 2 \mathrm{H}), 1.95(\mathrm{t}, J=7.5$, $2 \mathrm{H}), 1.42$ (p, $J=7.5,2 \mathrm{H}), 1.14$ (p, $J=7.9,1 \mathrm{H}) ;{ }^{13} \mathrm{C}$ NMR $\left(126 \mathrm{MHz}, \mathrm{DMSO}-d_{6}\right) \delta=172.08,33.84,28.83$, 25.54; HR-ESI-MS calcd. for $\mathrm{C}_{7} \mathrm{H}_{16} \mathrm{~N}_{4} \mathrm{O}_{2}[\mathrm{M}+\mathrm{H}]^{+}$: 189.23 , found 189.13

\section{Synthesis of tetramethylene diisocyanate}

The flow system in our work was set up as described in Figure S1.

Solution 1: sodium nitrite $(1.37 \mathrm{~g}, 0.02 \mathrm{~mol})$ was distilled into $100 \mathrm{~mL}$ deionized water. The concentration was $0.2 \mathrm{M}$

Solution 2: pure toluene

Solution 3: pimelic acid dihydrazide $(1.88 \mathrm{~g}, 0.01 \mathrm{~mol})$ was dissolved in $100 \mathrm{~mL}$ deionized water and 0.8 $\mathrm{mL}$ conc. $\mathrm{HCl}$. The concentration was $0.1 \mathrm{M}$.

All solutions were pumped with a flow rate of $1 \mathrm{~mL} \mathrm{~min}^{-1}$. The $1.62 \mathrm{~mL}$ coiled reactor was cooled down to $5-10^{\circ} \mathrm{C}$ in a cold bath, resulting in a residence time of $97 \mathrm{~s}$. The outlet then entered the Zaiput separator, which provides continuous separation of the two immiscible liquids, toluene and water. After complete separation, water exited on one side and was collected in a waste Erlenmeyer flask while the organic phase exited on the other side. The organic phase containing the azide product was directly sent to the drying unit with anhydrous sodium sulfate to remove trace water. Finally, the outlet was injected into a second 5 $\mathrm{mL}$ coiled reactor, which was heated to $85^{\circ} \mathrm{C}$ in a sand bath. The outlet containing tetramethylene diisocyanate product was placed in an Erlenmeyer flask. After removing solvent, tetramethylene diisocyanate was collected as a colorless liquid and stored at a temperature of $4{ }^{\circ} \mathrm{C}$. This system provides tetramethylene diisocyanate at a rate of $500 \mathrm{mg} \mathrm{h}^{-1}$.

Tetramethylene diisocyanate: ${ }^{1} \mathrm{H}$ NMR $(500 \mathrm{MHz}$, Chloroform- $d$ ) $\delta=3.33(\mathrm{t}, J=6.6,2 \mathrm{H}), 1.68-1.61$ (m, $1 \mathrm{H}), 1.48(\mathrm{tt}, J=10.4,6.0,1 \mathrm{H}) ;{ }^{13} \mathrm{C}$ NMR $(126 \mathrm{MHz}$, Chloroform- $d$ ) $\delta=138.00,129.16,128.35,125.42$, 42.87, 30.70, 23.75, 21.56; HR-ESI-MS calcd. for $\mathrm{C}_{7} \mathrm{H}_{10} \mathrm{~N}_{2} \mathrm{O}_{2}[\mathrm{M}+\mathrm{H}]^{+}:$155.17, found 155.05 


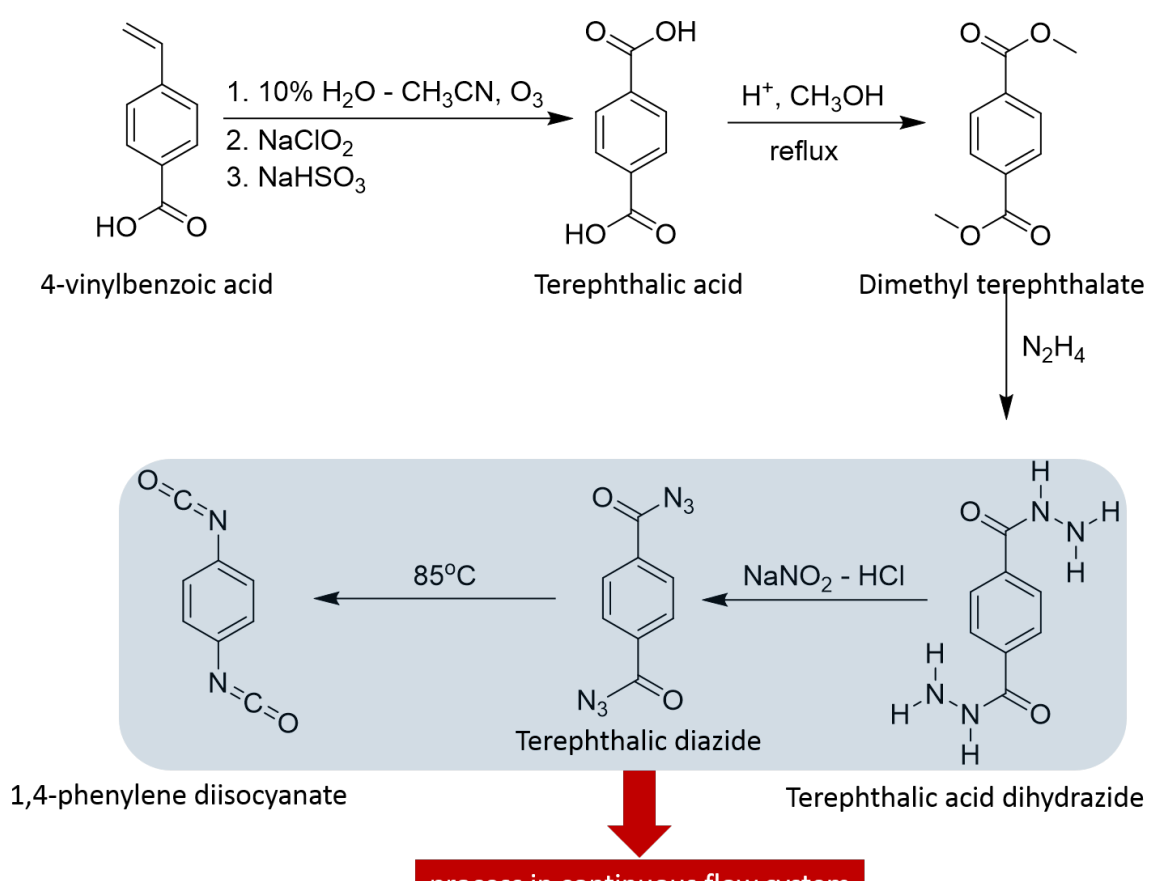

process in continuous flow system

Figure S8: Pathway to synthesize 1,4-phenylene diisocyanate from 4-vinylbenzoic acid

\section{Synthesis of terephthalic acid $^{8}$}

A solution of 4-vinylbenzoic acid (10 g, $0.06 \mathrm{~mol}, 1$ equiv) dissolved in $160 \mathrm{~mL}$ acetonitrile and $16 \mathrm{~mL}$ $\mathrm{H}_{2} \mathrm{O}$ was added to a $500 \mathrm{~mL}$ round-bottom flask. The solution was cooled to $0{ }^{\circ} \mathrm{C}$ in an ice bath and exposed to ozone. Complete reaction can be verified by thin-layer chromatography (TLC). Once the ozonolysis completed, a $135 \mathrm{~mL}$ aqueous solution of sodium chlorite $2 \mathrm{M}(24.41 \mathrm{~g}, 0.26 \mathrm{~mol}, 4$ equiv $)$ was slowly added to the cold reaction. The internal reaction temperature should be under $15^{\circ} \mathrm{C}$ during the portion-wise adding of $\mathrm{NaClO}_{2}$. The reaction mixture turned yellow after adding sodium chlorite solution. The mixture was then stirred overnight. Next, $135 \mathrm{~mL}$ aqueous solution of sodium bisulfite $2 \mathrm{M}(28.09 \mathrm{~g}, 0.26 \mathrm{~mol}, 4$ equiv) was dropped wise to the reaction mixture maintaining the temperature under $15^{\circ} \mathrm{C}$ The solution turned clear after the solution of sodium bisulfite was completely added. The mixture was stirred for 10 minutes. A white precipitate was filtered and washed with water $(100 \mathrm{~mL})$ to afford a white solid $(85 \%)$.

\section{Synthesis of dimethyl terephthalate}

Terephthalic acid $(10 \mathrm{~g}, 0.06 \mathrm{~mol})$, methanol $(110 \mathrm{~mL})$ and conc $\mathrm{H}_{2} \mathrm{SO}_{4}(2.7 \mathrm{~mL})$ were heated under reflux for $4 \mathrm{~h}^{9}$. Once the reaction complete, dichloromethane $(100 \mathrm{~mL})$ and water $(100 \mathrm{~mL})$ were added to the mixture. After separation, the organic phase was dried over anhydrous $\mathrm{Na}_{2} \mathrm{SO}_{4}$ and evaporated to afford a white solid (85\%).

Dimethyl terephthalate: ${ }^{1} \mathrm{H}$ NMR $\left(500 \mathrm{MHz}\right.$, Chloroform- $d$ ) $\delta=8.10(\mathrm{~s}, 3 \mathrm{H}), 3.95(\mathrm{~s}, 0 \mathrm{H}), 3.94(\mathrm{~s}, 6 \mathrm{H}) ;{ }^{13} \mathrm{C}$ NMR (126 MHz, Chloroform- $d$ ) $\delta=166.43,133.99,129.66,52.56$.

\section{Synthesis of terephthalic acid dihydrazide}

Dimethyl terephthalate $(6 \mathrm{~g}, 0.03 \mathrm{~mol})$, methanol $(60 \mathrm{~mL})$ and hydrazine $(9.6 \mathrm{~mL}, 0.3 \mathrm{~mol})$ were heated under reflux for $6 \mathrm{~h}^{9}$. The precipitated terephthalic acid dihydrazide was filtered and washed with methanol to afford a yellowish-white solid (85\%). 
Terephthalic acid dihydrazide: ${ }^{1} \mathrm{H}$ NMR $\left(500 \mathrm{MHz}, \mathrm{DMSO}-d_{6}\right) \delta=9.86(\mathrm{~s}, 3 \mathrm{H}), 7.98(\mathrm{~d}, J=8.1,1 \mathrm{H}), 7.89$ $(\mathrm{d}, J=8.2,1 \mathrm{H}), 7.82(\mathrm{~s}, 3 \mathrm{H}), 3.83(\mathrm{~s}, 1 \mathrm{H}) ;{ }^{13} \mathrm{C}$ NMR $\left(126 \mathrm{MHz}, \mathrm{DMSO}-d_{6}\right) \delta=165.74,135.98,129.72$, 127.91, 127.51; HR-ESI-MS calcd. for $\mathrm{C}_{8} \mathrm{H}_{10} \mathrm{~N}_{4} \mathrm{O}_{2}[\mathrm{M}+\mathrm{H}]^{+}: 195.19$, found 195.23

\section{Synthesis of 1,4-phenylene diisocyanate}

The flow system in our work was set up as described in Figure S3.

Solution 1: sodium nitrite $(1.37 \mathrm{~g}, 0.02 \mathrm{~mol})$ was distilled into $100 \mathrm{~mL}$ deionized water. The concentration was $0.2 \mathrm{M}$

Solution 2: a mixture of toluene and acetonitrile $(50 / 50 \mathrm{v} / \mathrm{v})$

Solution 3: terephthalic acid dihydrazide $(1.88 \mathrm{~g}, 0.01 \mathrm{~mol})$ was dissolved in $100 \mathrm{~mL}$ deionized water and $0.8 \mathrm{~mL}$ conc. $\mathrm{HCl}$. The concentration was $0.1 \mathrm{M}$.

All solutions were pumped with a flow rate of $1 \mathrm{~mL} \mathrm{~min}^{-1}$. The $1.62 \mathrm{~mL}$ coiled reactor was cooled down to $5-10^{\circ} \mathrm{C}$ in a cold bath, resulting in a residence time of $97 \mathrm{~s}$. The outlet then entered the Zaiput separator, which provides continuous separation of the two immiscible liquids, toluene and water. After complete separation, water exited on one side and was collected in a waste Erlenmeyer flask while the organic phase exited on the other side. The organic phase containing the azide product was directly sent to the drying unit with anhydrous sodium sulfate to remove trace water. Finally, the outlet was injected into a second 5 $\mathrm{mL}$ coiled reactor, which was heated to $85^{\circ} \mathrm{C}$ in a sand bath. The outlet containing 1,4-phenylene diisocyanate product was placed in an Erlenmeyer flask. After removing solvent, 1,4-phenylene diisocyanate was collected as an orange solid and stored at a temperature of $4{ }^{\circ} \mathrm{C}$. This system provides $1,4-$ phenylene diisocyanate at a rate of $500 \mathrm{mg} \mathrm{h}^{-1}$.

1,4-phenylene diisocyanate: ${ }^{1} \mathrm{H}$ NMR $(500 \mathrm{MHz}$, Chloroform- $d$ ) $\delta=8.15-8.06(\mathrm{~m}, 2 \mathrm{H}), 8.10(\mathrm{~s}, 6 \mathrm{H}), 8.00$ $(\mathrm{t}, J=7.7,1 \mathrm{H}), 7.26(\mathrm{t}, J=7.4,5 \mathrm{H}), 7.21-7.11(\mathrm{~m}, 9 \mathrm{H}), 3.96(\mathrm{~s}, 2 \mathrm{H}), 2.94(\mathrm{~s}, 1 \mathrm{H}), 2.36(\mathrm{~s}, 8 \mathrm{H}), 1.98(\mathrm{~s}, 0 \mathrm{H})$, 1.28 (q, $J=9.1,7.3,1 \mathrm{H}), 0.90$ (q, $J=6.6,1 \mathrm{H}) ;{ }^{13} \mathrm{C}$ NMR $(126 \mathrm{MHz}$, Chloroform- $d$ ) $\delta=171.76,137.98$, $135.37,134.30,131.19,129.91,129.72,129.52$, 129.16, 128.35, 127.86, 125.43, 125.13, 124.82, 52.67, 21.56; HR-ESI-MS calcd. for $\mathrm{C}_{8} \mathrm{H}_{4} \mathrm{~N}_{2} \mathrm{O}_{2}[\mathrm{M}+\mathrm{H}]^{+}: 161.13$, found 161.02

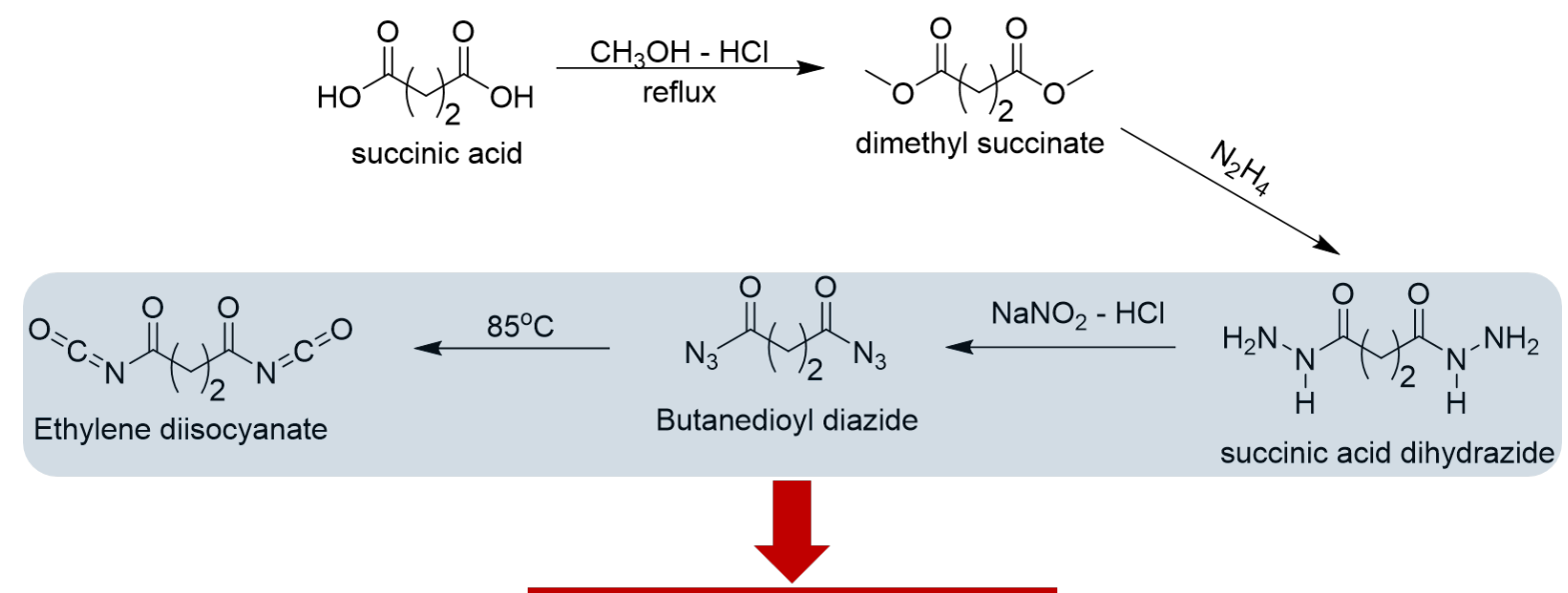

process in continuous flow system

Figure S9: Pathway to synthesize ethylene diisocyante from succinic acid

\section{Synthesis of dimethyl succinate:}

Succinic acid (5 g, $0.04 \mathrm{~mol})$ was added to a $100 \mathrm{~mL}$ one-neck round-bottom flask, then $50 \mathrm{~mL}$ methanolic $\mathrm{HCl} 1 \mathrm{M}$ was poured into this flask. The reaction was reflux for $2 \mathrm{~h}$. Once finishing reaction, $50 \mathrm{~mL}$ hexane 
was added to the flask. Two layers were divided by separating funnel. The organic layer was dried over anhydrous $\mathrm{Na}_{2} \mathrm{SO}_{4}$, and evaporated to afford dimethyl succinate as a colorless oil with the yield of $78 \%$.

Dimethyl succinate: ${ }^{1} \mathrm{H}$ NMR $(500 \mathrm{MHz}$, Chloroform- $d$ ) $\delta=3.64(\mathrm{~s}, 2 \mathrm{H}), 2.58(\mathrm{~s}, 1 \mathrm{H})$.

\section{Synthesis of succinic acid dihydrazide}

$6.5 \mathrm{~mL} \mathrm{~N}_{2} \mathrm{H}_{4}(0.2 \mathrm{~mol})$ was added slowly to $30 \mathrm{~mL}$ methanol contain $3 \mathrm{~g}$ dimethyl succinate $(0.02 \mathrm{~mol})$ in $100 \mathrm{~mL}$ one-neck round-bottom flask. The reaction was refluxed for $6 \mathrm{~h}$. After cooling down, succinic acid dihydrazide ( $79 \%$ in yield) is collected as a white powder after filtration and washing with methanol.

${ }^{1} \mathrm{H}$ NMR $\left(500 \mathrm{MHz}, \mathrm{DMSO}-d_{6}\right) \delta=8.95(\mathrm{~s}, 2 \mathrm{H}), 4.10(\mathrm{~s}, 4 \mathrm{H}), 2.21(\mathrm{~s}, 3 \mathrm{H}) ;{ }^{13} \mathrm{C}$ NMR $(126 \mathrm{MHz}, \mathrm{DMSO}-$ $\left.d_{6}\right) \delta=171.32$, 29.46; HR-ESI-MS calcd. for $\mathrm{C}_{4} \mathrm{H}_{10} \mathrm{~N}_{4} \mathrm{O}_{2}[\mathrm{M}+\mathrm{H}]^{+}:$147.15, found 147.06.

\section{Synthesis of ethylene diisocyanate}

The flow system in our work was set up as described in Figure S1.

Solution 1: sodium nitrite $(0.55 \mathrm{~g}, 0.008 \mathrm{~mol})$ was distilled into $100 \mathrm{~mL}$ deionized water. The concentration was $0.2 \mathrm{M}$

Solution 2: pure toluene

Solution 3: succinic acid hydrazide $(0.58 \mathrm{~g}, 0.004 \mathrm{~mol})$ was dissolved in $40 \mathrm{~mL}$ deionized water and $1.3 \mathrm{~mL}$ aqueous $\mathrm{HCl} 6 \mathrm{~N}$.

All solutions were pumped with a flow rate of $1 \mathrm{~mL} \mathrm{~min}^{-1}$. The $1.62 \mathrm{~mL}$ coiled reactor was cooled down to $5-10^{\circ} \mathrm{C}$ in a cold bath, resulting in a residence time of $97 \mathrm{~s}$. The outlet then entered the Zaiput separator, which provides continuous separation of the two immiscible liquids, toluene and water. After complete separation, water exited on one side and was collected in a waste Erlenmeyer flask while the organic phase exited on the other side. The organic phase containing the azide product was directly sent to the drying unit with anhydrous sodium sulfate to remove trace water. Finally, the outlet was injected into a second 5 $\mathrm{mL}$ coiled reactor, which was heated to $85{ }^{\circ} \mathrm{C}$ in a sand bath. The outlet containing desired product was placed in an Erlenmeyer flask. After removing solvent, ethylene diisocyanate was collected as a colorless liquid (70\%) and stored at a temperature of $4{ }^{\circ} \mathrm{C}$.

${ }^{1} \mathrm{H}$ NMR (500 MHz, Chloroform- $d$ ) $\delta=7.31(\mathrm{t}, J=7.5,2 \mathrm{H}), 7.22(\mathrm{~d}, J=6.8,2 \mathrm{H}), 3.47(\mathrm{~s}, 6 \mathrm{H}), 2.41(\mathrm{~s}, 3 \mathrm{H})$; ${ }^{13} \mathrm{C}$ NMR (126 MHz, Chloroform- $d$ ) $\delta=138.06,129.22,129.17,128.40,125.47,125.42,123.99,44.01$, 21.60, 21.55, 21.50, 21.45; HR-ESI-MS calcd. for $\mathrm{C}_{4} \mathrm{H}_{4} \mathrm{~N}_{2} \mathrm{O}_{2}[\mathrm{M}+\mathrm{MeOH}+\mathrm{H}]^{+}: 145.04$, found 145.13 
<smiles>O=C(O)c1cccc(C(=O)O)c1</smiles>

Isophthalic acid

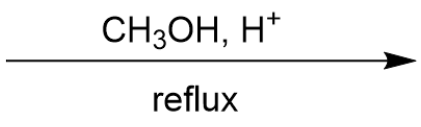

reflux<smiles>COC(=O)c1cccc(C(=O)OC)c1</smiles>

Dimethyl isophthalate

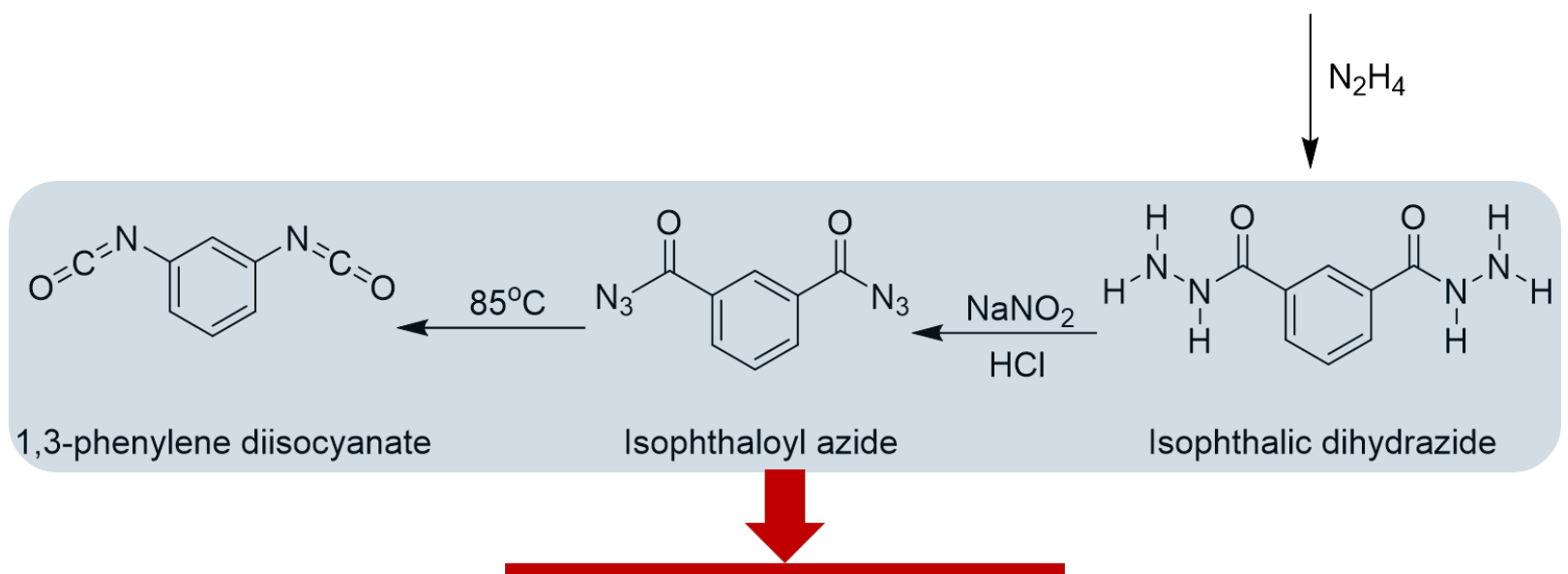

process in continuous flow system

Figure S10: Pathway to synthesize 1,3-phenylene diisocyanate from isophthalic acid

\section{Synthesis of dimethyl isophthalate}

Isophthalic acid $(5.89 \mathrm{~g}, 0.035 \mathrm{~mol})$ was added to a $100 \mathrm{~mL}$ one-neck round-bottom flask, then $40 \mathrm{~mL}$ methanolic $\mathrm{HCl} 1 \mathrm{M}$ was poured into this flask. The reaction was reflux for $2 \mathrm{~h}$. Once finishing reaction, 100 $\mathrm{mL}$ hexane was added to the flask. Two layers were divided by separating funnel. The organic layer was dried over anhydrous $\mathrm{Na}_{2} \mathrm{SO}_{4}$, and evaporated to afford desired product as a white powder with the yield of $80 \%$.

Dimethyl isophthalate: ${ }^{1} \mathrm{H}$ NMR $(500 \mathrm{MHz}$, Chloroform- $d$ ) $\delta=8.68(\mathrm{~s}, 1 \mathrm{H}), 8.25(\mathrm{~s}, 1 \mathrm{H}), 8.23(\mathrm{dd}, J=8.0$, $1.7,2 \mathrm{H}), 7.59-7.50(\mathrm{~m}, 1 \mathrm{H}), 3.95(\mathrm{~s}, 8 \mathrm{H}) ;{ }^{13} \mathrm{C}$ NMR $(126 \mathrm{MHz}$, Chloroform- $d) \delta=166.38,133.92,130.83$, $130.69,128.75,52.49$.

\section{Synthesis of Isophthalic dihydrazide}

$8.0 \mathrm{~mL} \mathrm{~N}_{2} \mathrm{H}_{4}(0.25 \mathrm{~mol})$ was added slowly to $50 \mathrm{~mL}$ methanol contain $5 \mathrm{~g}$ dimethyl isophthalate $(0.025$ mol) in $150 \mathrm{~mL}$ one-neck round-bottom flask. The reaction was refluxed for $6 \mathrm{~h}$. After cooling down, isophthalic dihydrazide ( $83 \%$ in yield) is collected as a white powder after filtration and washing with methanol.

Isophthalic dihydrazide: ${ }^{1} \mathrm{H}$ NMR $\left(500 \mathrm{MHz}, \mathrm{DMSO}-d_{6}\right) \delta=9.80(\mathrm{~s}, 2 \mathrm{H}), 8.22(\mathrm{~s}, 1 \mathrm{H}), 7.88(\mathrm{~d}, J=7.5,2 \mathrm{H})$, $7.49(\mathrm{t}, J=7.7,1 \mathrm{H}), 4.51(\mathrm{~s}, 4 \mathrm{H}) ;{ }^{13} \mathrm{C}$ NMR $\left(126 \mathrm{MHz}, \mathrm{DMSO}-d_{6}\right) \delta=166.01,134.06,129.85,128.99$, 126.57; HR-ESI-MS calcd. for $\mathrm{C}_{8} \mathrm{H}_{10} \mathrm{~N}_{4} \mathrm{O}_{2}[\mathrm{M}+\mathrm{H}]^{+}: 195.19$, found 195.18

\section{Synthesis of 1,3-phenylene diisocyanate}

The flow system in our work was set up as described in Figure S1.

Solution 1: sodium nitrite $(0.34 \mathrm{~g}, 0.005 \mathrm{~mol})$ was distilled into $50 \mathrm{~mL}$ deionized water.

Solution 2: pure toluene 
Solution 3: isophthalic dihydrazide $(0.48 \mathrm{~g}, 0.0025 \mathrm{~mol})$ was dissolved in $50 \mathrm{~mL}$ deionized water and 0.8 $\mathrm{mL}$ aqueous $\mathrm{HCl} 6 \mathrm{~N}$.

All solutions were pumped with a flow rate of $1 \mathrm{~mL} \mathrm{~min}^{-1}$. The $1.62 \mathrm{~mL}$ coiled reactor was cooled down to $5-10^{\circ} \mathrm{C}$ in a cold bath, resulting in a residence time of $97 \mathrm{~s}$. The outlet then entered the Zaiput separator, which provides continuous separation of the two immiscible liquids, toluene and water. After complete separation, water exited on one side and was collected in a waste Erlenmeyer flask while the organic phase exited on the other side. The organic phase containing the azide product was directly sent to the drying unit with anhydrous sodium sulfate to remove trace water. Finally, the outlet was injected into a second 5 $\mathrm{mL}$ coiled reactor, which was heated to $85^{\circ} \mathrm{C}$ in a sand bath. The outlet containing desired product was placed in an Erlenmeyer flask. After removing solvent, 1,3-phenylene diisocyanate was collected as a pale yellow powder $(65 \%)$ and stored at a temperature of $4{ }^{\circ} \mathrm{C}$.

1,3-phenylene diisocyanate: ${ }^{1} \mathrm{H}$ NMR $(500 \mathrm{MHz}$, Chloroform- $d) \delta=7.55-7.46(\mathrm{~m}, 3 \mathrm{H}), 7.41(\mathrm{~d}, J=7.6$, 4H), 2.59 (s, 5H); ${ }^{13} \mathrm{C}$ NMR (126 MHz, Chloroform- $d$ ) $\delta=138.13,134.93,130.67,130.54,130.18,129.39$, $128.59,126.88,125.74,125.68,122.49,21.73$; HR-ESI-MS calcd. for $\mathrm{C}_{8} \mathrm{H}_{4} \mathrm{~N}_{2} \mathrm{O}_{2}[\mathrm{M}+\mathrm{H}]^{+}: 161.13$, found 161.23

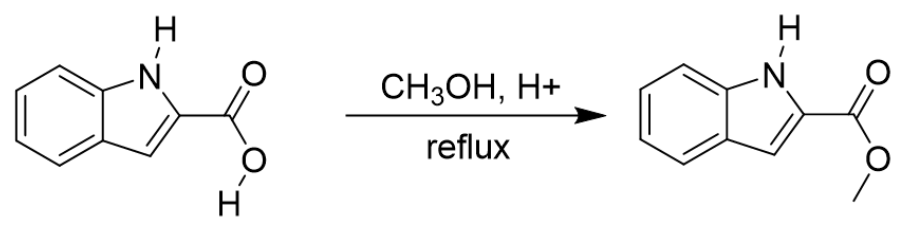

indole-2-carboxylic acid

Methyl 2-indolecarboxylate
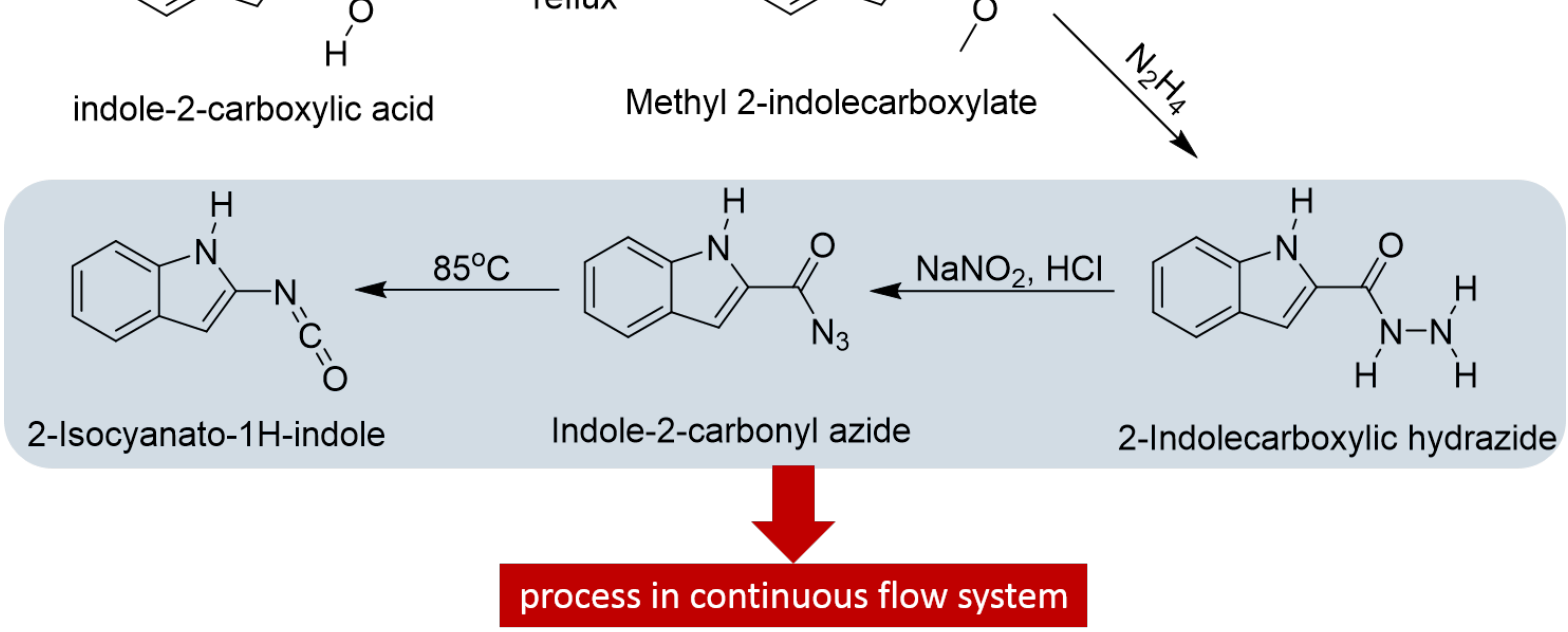

Figure S11: Pathway to synthesize 2-isocyanato-1H-indole

\section{Synthesis of methyl 2-indolecarboxylate}

Indole-2-carboxylic acid (3g, $0.018 \mathrm{~mol})$ was added to a $100 \mathrm{~mL}$ one-neck round-bottom flask, then $50 \mathrm{~mL}$ methanolic $\mathrm{HCl} 1 \mathrm{M}$ was poured into this flask. The reaction was reflux for $2 \mathrm{~h}$. Once finishing reaction, 100 $\mathrm{mL}$ hexane was added to the flask. Two layers were divided by separating funnel. The organic layer was dried over anhydrous $\mathrm{Na}_{2} \mathrm{SO}_{4}$, and evaporated to afford desired product as a light brown powder oil with the yield of $80 \%$.

Methyl 2-indolecarboxylate: ${ }^{1} \mathrm{H}$ NMR $(500 \mathrm{MHz}$, Chloroform- $d$ ) $\delta=8.91(\mathrm{~s}, 1 \mathrm{H}), 7.70(\mathrm{~d}, J=8.0,1 \mathrm{H}), 7.42$ $(\mathrm{d}, J=8.3,1 \mathrm{H}), 7.33(\mathrm{t}, J=7.7,1 \mathrm{H}), 7.23(\mathrm{~d}, J=2.1,1 \mathrm{H}), 7.19-7.12(\mathrm{~m}, 1 \mathrm{H}), 3.95(\mathrm{~s}, 3 \mathrm{H}) ;{ }^{13} \mathrm{C}$ NMR $(126$ MHz, Chloroform- $d$ ) $\delta=125.56,122.76,120.96,111.96,108.91,52.14$. 


\section{Synthesis of 2-Indolecarboxylic hydrazide}

$4 \mathrm{~mL} \mathrm{~N}_{2} \mathrm{H}_{4}(0.125 \mathrm{~mol})$ was added slowly to $25 \mathrm{~mL}$ methanol contain $2.2 \mathrm{~g}$ methyl-2-indolecarboxylate $(0.0125 \mathrm{~mol})$ in $100 \mathrm{~mL}$ one-neck round-bottom flask. The reaction was refluxed for $6 \mathrm{~h}$. After cooling down, 2-indolecarboxylic hydrazide ( $75 \%$ in yield) is collected as a white powder after filtration and washing with methanol.

2-Indolecarboxylic hydrazide: ${ }^{1} \mathrm{H}$ NMR $\left(500 \mathrm{MHz}, \mathrm{DMSO}-d_{6}\right) \delta=11.53(\mathrm{~s}, 1 \mathrm{H}), 9.77(\mathrm{~s}, 1 \mathrm{H}), 7.55(\mathrm{~d}$, $J=7.9,1 \mathrm{H}), 7.40(\mathrm{~d}, J=8.2,1 \mathrm{H}), 7.13(\mathrm{t}, J=7.6,1 \mathrm{H}), 7.04(\mathrm{~s}, 1 \mathrm{H}), 6.99(\mathrm{t}, J=7.4,1 \mathrm{H}) ;{ }^{13} \mathrm{C}$ NMR $(126 \mathrm{MHz}$, DMSO- $\left.d_{6}\right) \delta=161.79,136.85,130.88,127.62,123.79,121.97,120.34,112.81,102.55$; HR-ESI-MS calcd. for $\mathrm{C}_{9} \mathrm{H}_{9} \mathrm{~N}_{3} \mathrm{O}[\mathrm{M}+\mathrm{H}]^{+}:$176.19, found 176.15 .

\section{Synthesis of 2-Isocyanato-1H-indole}

The flow system in our work was set up as described in Figure S1.

Solution 1: sodium nitrite $(0.37 \mathrm{~g}, 0.005 \mathrm{~mol})$ was distilled into $100 \mathrm{~mL}$ deionized water.

Solution 2: pure toluene

Solution 3: 2-indolecarboxylic hydrazide $(0.44 \mathrm{~g}, 0.0025 \mathrm{~mol})$ was dissolved in $50 \mathrm{~mL}$ deionized water and $0.8 \mathrm{~mL}$ aqueous $\mathrm{HCl} 6 \mathrm{~N}$.

All solutions were pumped with a flow rate of $1 \mathrm{~mL} \mathrm{~min}^{-1}$. The $1.62 \mathrm{~mL}$ coiled reactor was cooled down to $5-10^{\circ} \mathrm{C}$ in a cold bath, resulting in a residence time of $97 \mathrm{~s}$. The outlet then entered the Zaiput separator, which provides continuous separation of the two immiscible liquids, toluene and water. After complete separation, water exited on one side and was collected in a waste Erlenmeyer flask while the organic phase exited on the other side. The organic phase containing the azide product was directly sent to the drying unit with anhydrous sodium sulfate to remove trace water. Finally, the outlet was injected into a second 5 $\mathrm{mL}$ coiled reactor, which was heated to $85{ }^{\circ} \mathrm{C}$ in a sand bath. The outlet containing desired product was placed in an Erlenmeyer flask. After removing solvent, desired product was collected as a dark brown liquid $(76 \%)$ and stored at a temperature of $4{ }^{\circ} \mathrm{C}$.

2-Isocyanato-1H-indole: ${ }^{1} \mathrm{H}$ NMR $(500 \mathrm{MHz}$, Chloroform- $d$ ) $\delta=7.24(\mathrm{t}, J=7.4,1 \mathrm{H}), 7.15$ (dd, $J=13.7,7.2$, 2H), $2.34(\mathrm{~s}, 2 \mathrm{H}), 1.92(\mathrm{~s}, 6 \mathrm{H}), 1.34-1.24(\mathrm{~m}, 1 \mathrm{H}), 0.92-0.83(\mathrm{~m}, 1 \mathrm{H}) ;{ }^{13} \mathrm{C}$ NMR $(126 \mathrm{MHz}$, Chloroformd) $\delta=137.95,129.14,128.35,126.58,125.42,123.04,121.28,116.75,112.46,110.83,53.75,31.70,22.76$, 21.46, 14.19, 1.74; HR-ESI-MS calcd. for $\mathrm{C}_{9} \mathrm{H}_{6} \mathrm{~N}_{2} \mathrm{O}[\mathrm{M}+\mathrm{H}]^{+}: 159.16$, found 159.22

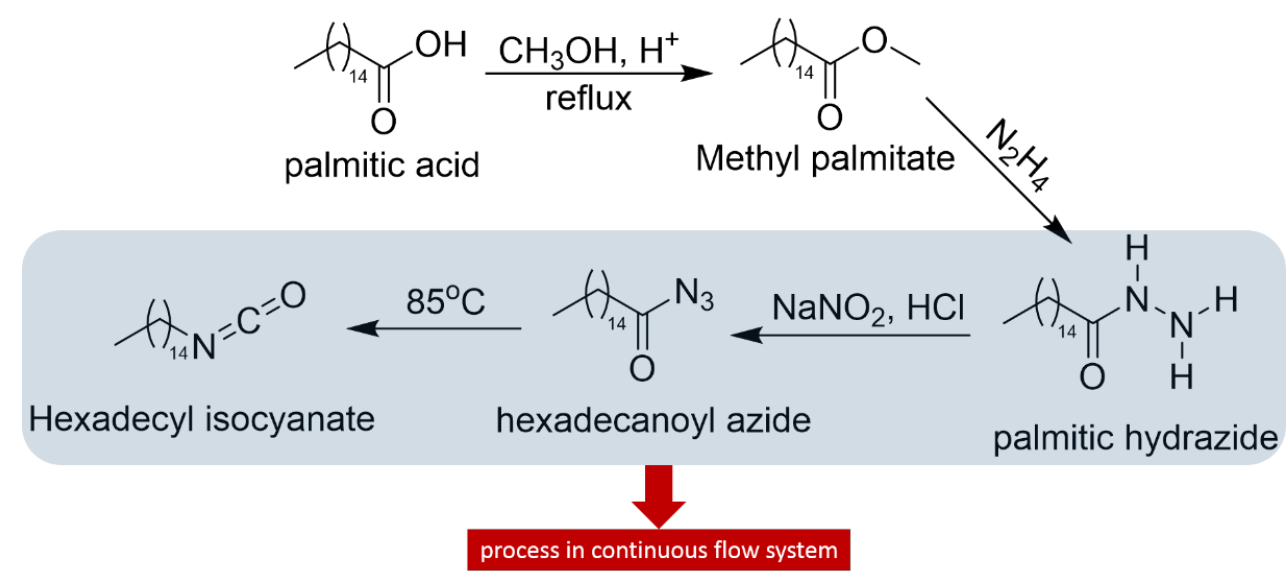

Figure S12: Pathway to synthesize hexadecyl isocyanate 


\section{Synthesis of methyl palmitate}

Palmitic acid $(6.36 \mathrm{~g}, 0.025 \mathrm{~mol})$ was added to a $250 \mathrm{~mL}$ one-neck round-bottom flask, then $50 \mathrm{~mL}$ methanolic $\mathrm{HCl} 1 \mathrm{M}$ was poured into this flask. The reaction was reflux for $2 \mathrm{~h}$. Once finishing reaction, 100 $\mathrm{mL}$ hexane was added to the flask. Two layers were divided by separating funnel. The organic layer was dried over anhydrous $\mathrm{Na}_{2} \mathrm{SO}_{4}$, and evaporated to afford desired product as a pale yellow oil with the yield of $80 \%$.

Methyl palmitate: ${ }^{1} \mathrm{H}$ NMR $(500 \mathrm{MHz}$, Chloroform- $d$ ) $\delta=3.65(\mathrm{~s}, 1 \mathrm{H}), 2.29(\mathrm{t}, J=7.6,1 \mathrm{H}), 1.64-1.57$ (m, $1 \mathrm{H}), 1.28(\mathrm{dt}, J=13.9,6.4,5 \mathrm{H}), 1.24(\mathrm{~s}, 7 \mathrm{H}), 0.90-0.82(\mathrm{~m}, 2 \mathrm{H}) ;{ }^{13} \mathrm{C}$ NMR $(126 \mathrm{MHz}$, Chloroform- $d) \delta=$ $174.44,51.51,34.20,32.02,31.69,29.78,29.74,29.69,29.55,29.46,29.36,29.25,27.31,25.05,22.79$, $22.75,14.20$

\section{Synthesis of palmitic hydrazide}

$2.5 \mathrm{~mL} \mathrm{~N}_{2} \mathrm{H}_{4}(0.073 \mathrm{~mol})$ was added slowly to $40 \mathrm{~mL}$ methanol contain $2 \mathrm{~g}$ methyl palmitate $(0.0073 \mathrm{~mol})$ in $100 \mathrm{~mL}$ one-neck round-bottom flask. The reaction was refluxed for $6 \mathrm{~h}$. After cooling down, desired product (68\% in yield) is collected as a white powder after filtration and washing with methanol.

Palmitic hydrazide: ${ }^{1} \mathrm{H}$ NMR $\left(500 \mathrm{MHz}, \mathrm{DMSO}-d_{6}\right) \delta=8.89(\mathrm{~s}, 1 \mathrm{H}), 2.68(\mathrm{~s}, 1 \mathrm{H}), 1.95(\mathrm{t}, J=7.4,2 \mathrm{H}), 1.42$ $(\mathrm{s}, 3 \mathrm{H}), 1.19(\mathrm{~s}, 22 \mathrm{H}), 1.18(\mathrm{~s}, 2 \mathrm{H}), 0.81(\mathrm{t}, J=6.7,3 \mathrm{H})$; HR-ESI-MS calcd. for $\mathrm{C}_{16} \mathrm{H}_{34} \mathrm{~N}_{2} \mathrm{O}[\mathrm{M}+\mathrm{H}]^{+}: 271.45$, found 271.40 .

\section{Synthesis of hexadecyl isocyanate}

The flow system in our work was set up as described in Figure S1.

Solution 1: sodium nitrite $(0.35 \mathrm{~g}, 0.005 \mathrm{~mol})$ was distilled into $50 \mathrm{~mL}$ deionized water.

Solution 2: pure toluene

Solution 3: palmitic hydrazide $(0.68 \mathrm{~g}, 0.0025 \mathrm{~mol})$ was dissolved in $50 \mathrm{~mL}$ deionized water and $0.8 \mathrm{~mL}$ aqueous $\mathrm{HCl} 6 \mathrm{~N}$.

All solutions were pumped with a flow rate of $1 \mathrm{~mL} \mathrm{~min}^{-1}$. The $1.62 \mathrm{~mL}$ coiled reactor was cooled down to $5-10^{\circ} \mathrm{C}$ in a cold bath, resulting in a residence time of $97 \mathrm{~s}$. The outlet then entered the Zaiput separator, which provides continuous separation of the two immiscible liquids, toluene and water. After complete separation, water exited on one side and was collected in a waste Erlenmeyer flask while the organic phase exited on the other side. The organic phase containing the azide product was directly sent to the drying unit with anhydrous sodium sulfate to remove trace water. Finally, the outlet was injected into a second 5 $\mathrm{mL}$ coiled reactor, which was heated to $85^{\circ} \mathrm{C}$ in a sand bath. The outlet containing desired product was

placed in an Erlenmeyer flask. After removing solvent, desired product was collected as a pale yellow liquid $(72 \%)$ and stored at a temperature of $4{ }^{\circ} \mathrm{C}$.

Hexadecyl isocyanate: ${ }^{1} \mathrm{H}$ NMR $(500 \mathrm{MHz}$, Chloroform- $d$ ) $\delta=7.45(\mathrm{t}, J=7.5,5 \mathrm{H}), 7.37$ (dd, $J=7.9,3.0$, $8 \mathrm{H}), 2.55(\mathrm{~s}, 9 \mathrm{H}), 1.96(\mathrm{~s}, 2 \mathrm{H}), 1.13(\mathrm{t}, J=6.8,1 \mathrm{H}) .{ }^{13} \mathrm{C}$ NMR $(126 \mathrm{MHz}$, Chloroform- $d) \delta=138.11,129.35$, 128.54, 125.63, 116.61, 31.96, 30.08, 30.04, 29.75, 23.02, 21.69, 14.44, 1.70. HR-ESI-MS calcd. for $\mathrm{C}_{16} \mathrm{H}_{31} \mathrm{NO}[\mathrm{M}+\mathrm{MeOH}+\mathrm{H}]^{+}: 286.49$, found 286.26 


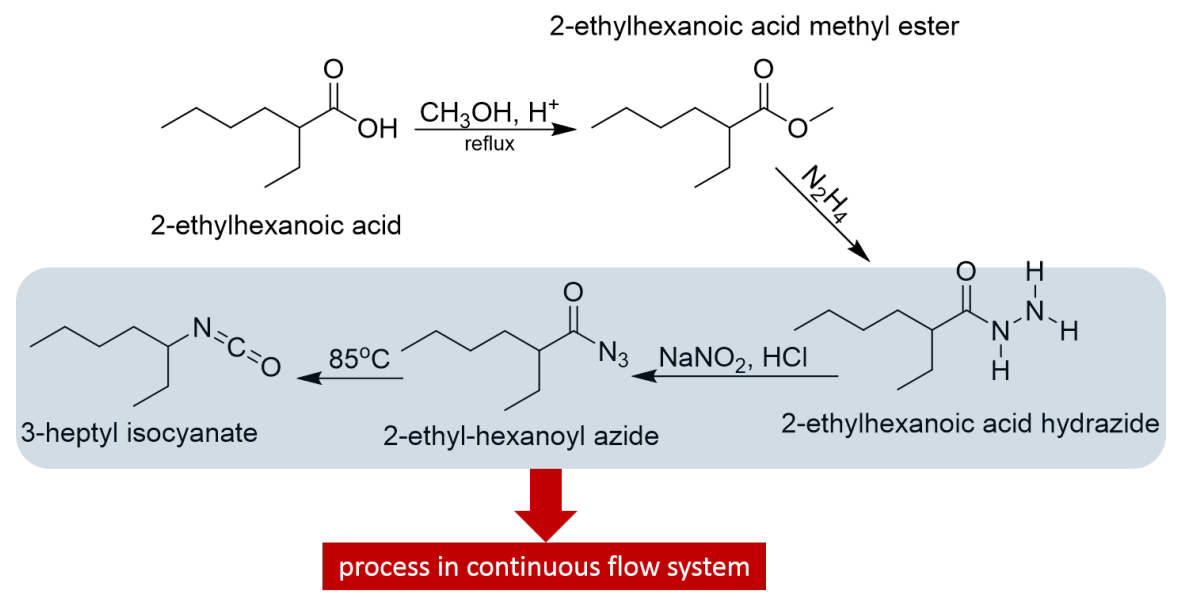

Figure S13. Pathway to synthesize 3-heptyl isocyanate

\section{Synthesis of 2-ethylhexanoic acid methyl ester:}

2-ethylhexanoic acid $(5.85 \mathrm{~g}, 0.04 \mathrm{~mol})$ was added to a $100 \mathrm{~mL}$ one-neck round-bottom flask, then $50 \mathrm{~mL}$ methanolic $\mathrm{HCl} 1 \mathrm{M}$ was poured into this flask. The reaction was reflux for $2 \mathrm{~h}$. Once finishing reaction, 100 $\mathrm{mL}$ hexane was added to the flask. Two layers were divided by separating funnel. The organic layer was dried over anhydrous $\mathrm{Na}_{2} \mathrm{SO}_{4}$, and evaporated to afford desired product as a colorless oil with the yield of $85 \%$.

2-Ethylhexanoic acid methyl ester: ${ }^{1} \mathrm{H}$ NMR $(500 \mathrm{MHz}$, Chloroform- $d$ ) $\delta=3.66(\mathrm{~s}, 2 \mathrm{H}), 2.25$ (tt, $J=8.7$, $5.3,1 \mathrm{H}), 1.66-1.38(\mathrm{~m}, 3 \mathrm{H}), 1.35-1.15(\mathrm{~m}, 4 \mathrm{H}), 0.86(\mathrm{t}, J=7.3,5 \mathrm{H}) .{ }^{13} \mathrm{C}$ NMR $(126 \mathrm{MHz}$, Chloroformd) $\delta=177.05,51.35,47.36,31.90,31.68,29.74,25.57,25.35,22.71,14.18,14.01,11.92$.

\section{Synthesis of 2-ethylhexanoic acid hydrazide:}

$4 \mathrm{~mL} \mathrm{~N}_{2} \mathrm{H}_{4}(0.5 \mathrm{~mol})$ was added slowly to $40 \mathrm{~mL}$ methanol contain $2 \mathrm{~g}$ 2-ethylhexanoic acid methyl ester $(0.012 \mathrm{~mol})$ in $150 \mathrm{~mL}$ one-neck round-bottom flask. The reaction was refluxed for $6 \mathrm{~h}$. After cooling down, a desired product ( $68 \%$ in yield) is collected as a white powder after filtration and washing with methanol. 2-ethylhexanoic acid hydrazide: ${ }^{1} \mathrm{H}$ NMR $\left(500 \mathrm{MHz}, \mathrm{DMSO}-d_{6}\right) \delta=3.55(\mathrm{~s}, 3 \mathrm{H}), 2.20(\mathrm{tt}, J=8.6,5.5,1 \mathrm{H})$, $1.52-1.42(\mathrm{~m}, 2 \mathrm{H}), 1.45-1.37(\mathrm{~m}, 2 \mathrm{H}), 1.40-1.31(\mathrm{~m}, 1 \mathrm{H}), 1.29-1.04(\mathrm{~m}, 4 \mathrm{H}), 0.83-0.69(\mathrm{~m}, 8 \mathrm{H})$. ${ }^{13} \mathrm{C}$ NMR $\left(126 \mathrm{MHz}, \mathrm{DMSO}-d_{6}\right) \delta=176.37,51.62,46.93,46.10,32.41,31.78,29.78,29.59,26.03,25.50$, $22.69,22.57,14.38,14.26,12.36,12.09$. HR-ESI-MS calcd. for $\mathrm{C}_{8} \mathrm{H}_{18} \mathrm{~N}_{2} \mathrm{O}[\mathrm{M}+\mathrm{H}]^{+}: 159.24$, found 159.23

\section{Synthesis of 3-heptyl isocyanate:}

The flow system in our work was set up as described in Figure S1.

Solution 1: sodium nitrite $(0.34 \mathrm{~g}, 0.005 \mathrm{~mol})$ was distilled into $50 \mathrm{~mL}$ deionized water.

Solution 2: pure toluene

Solution 3: 2-ethylhexanoic acid hydrazide $(0.39 \mathrm{~g}, 0.0025 \mathrm{~mol})$ was dissolved in $50 \mathrm{~mL}$ deionized water and $0.8 \mathrm{~mL}$ aqueous $\mathrm{HCl} 6 \mathrm{~N}$.

All solutions were pumped with a flow rate of $1 \mathrm{~mL} \mathrm{~min}^{-1}$. The $1.62 \mathrm{~mL}$ coiled reactor was cooled down to $5-10^{\circ} \mathrm{C}$ in a cold bath, resulting in a residence time of $97 \mathrm{~s}$. The outlet then entered the Zaiput separator, which provides continuous separation of the two immiscible liquids, toluene and water. After complete separation, water exited on one side and was collected in a waste Erlenmeyer flask while the organic phase exited on the other side. The organic phase containing the azide product was directly sent to the drying unit with anhydrous sodium sulfate to remove trace water. Finally, the outlet was injected into a second 5 
$\mathrm{mL}$ coiled reactor, which was heated to $85{ }^{\circ} \mathrm{C}$ in a sand bath. The outlet containing desired product was placed in an Erlenmeyer flask. After removing solvent, desired product was collected as a colorless liquid $(71 \%)$ and stored at a temperature of $4{ }^{\circ} \mathrm{C}$.

3-Heptyl isocyanate: ${ }^{1} \mathrm{H}$ NMR (500 MHz, Chloroform- $d$ ) $\delta=7.31(\mathrm{t}, J=7.5,6 \mathrm{H}), 7.27-7.18(\mathrm{~m}, 5 \mathrm{H}), 3.40$ (ddd, $J=12.9,8.1,4.7,1 \mathrm{H}), 2.41$ (s, 9H), $1.70-1.45(\mathrm{~m}, 5 \mathrm{H}), 1.45-1.29(\mathrm{~m}, 4 \mathrm{H}), 1.07-0.93(\mathrm{~m}, 7 \mathrm{H}) .{ }^{13} \mathrm{C}$ NMR (126 MHz, Chloroform- $d$ ) $\delta=138.02,129.21,128.40,125.47,57.99,36.32,30.03,28.48,22.52$, 21.60, 14.14, 10.65. HR-ESI-MS calcd. for $\mathrm{C}_{8} \mathrm{H}_{15} \mathrm{NO}[\mathrm{M}+3 \mathrm{H}]^{+}: 144.21$, found 144.20

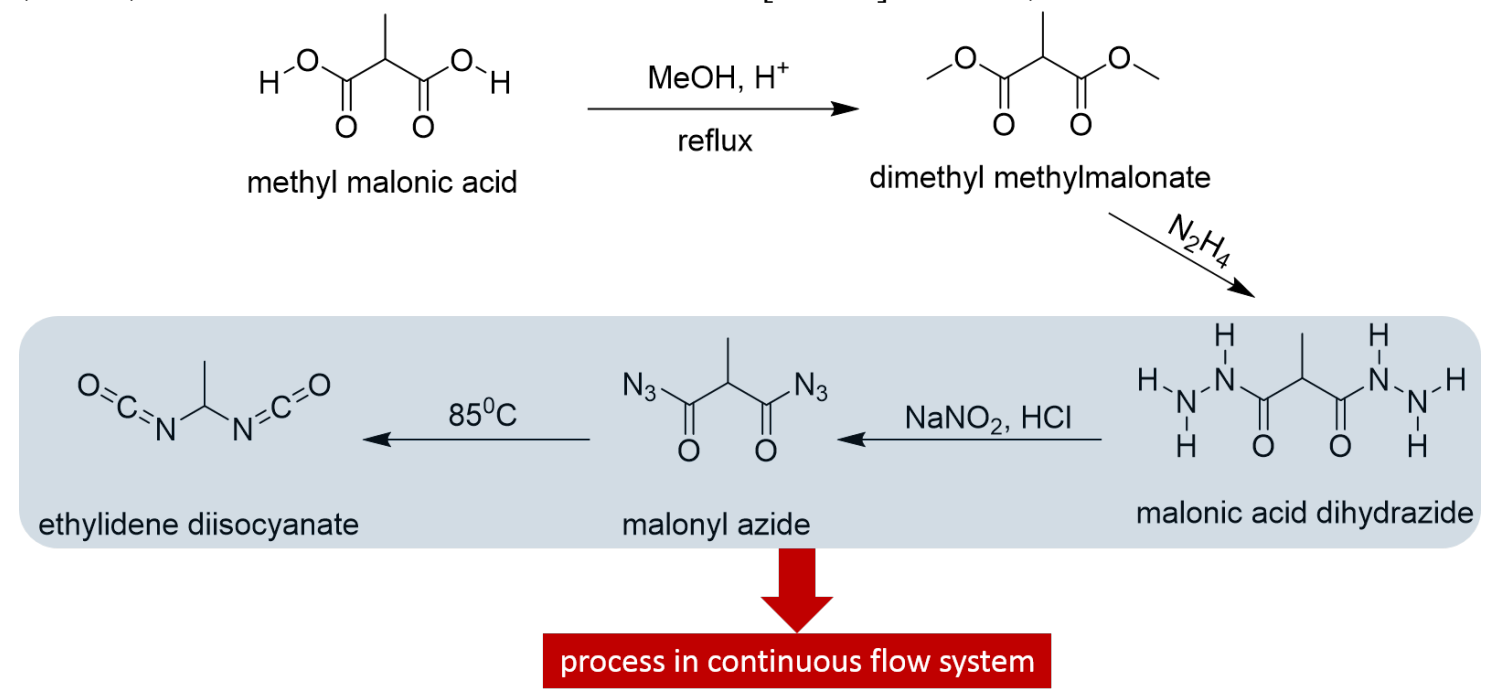

Figure S14. Pathway to synthesize ethylidene diisocyanate from methylmalonate

\section{Synthesis of dimethyl methylmalonate}

Methyl malonic acid $(0.5 \mathrm{~g}, 0.0042 \mathrm{~mol})$ was added to a $50 \mathrm{~mL}$ one-neck round-bottom flask, then $10 \mathrm{~mL}$ methanolic $\mathrm{HCl} 1 \mathrm{M}$ was poured into this flask. The reaction was reflux for $2 \mathrm{~h}$. Once finishing reaction, 20 $\mathrm{mL}$ hexane was added to the flask. Two layers were divided by separating funnel. The organic layer was dried over anhydrous $\mathrm{Na}_{2} \mathrm{SO}_{4}$, and evaporated to afford desired product as a colorless oil with the yield of $85 \%$.

Dimethyl methylmalonate: ${ }^{1} \mathrm{H}$ NMR (500 MHz, DMSO- $\left.d_{6}\right) \delta=3.62(\mathrm{~s}, 7 \mathrm{H}), 3.58(\mathrm{q}, J=7.3,1 \mathrm{H}), 1.24(\mathrm{~d}, J=7.1,4 \mathrm{H})$. ${ }^{13} \mathrm{C}$ NMR (126 MHz, DMSO-d6) $\delta=170.76,52.85,45.56,14.01$.

\section{Synthesis of malonic acid dihydrazide}

$0.8 \mathrm{~mL} \mathrm{~N}_{2} \mathrm{H}_{4}(0.023 \mathrm{~mol})$ was added slowly to $5 \mathrm{~mL}$ methanol contain $0.35 \mathrm{~g}$ dimethyl methylmalonate $(0.0023 \mathrm{~mol})$ in $20 \mathrm{~mL}$ one-neck round-bottom flask. The reaction was refluxed for $6 \mathrm{~h}$. After cooling down, desired product (57\% in yield) is collected as a white powder after filtration and washing with methanol.

Malonic acid dihydrazide: ${ }^{1} \mathrm{H}$ NMR $\left(500 \mathrm{MHz}, \mathrm{DMSO}-d_{6}\right) \delta=8.84(\mathrm{~s}, 2 \mathrm{H}), 4.18(\mathrm{~s}, 4 \mathrm{H}), 3.00(\mathrm{q}, J=7.1$, $1 \mathrm{H}), 1.13(\mathrm{~d}, J=7.3,3 \mathrm{H}) .{ }^{13} \mathrm{C}$ NMR $\left(126 \mathrm{MHz}, \mathrm{DMSO}-d_{6}\right) \delta=170.04,44.19,14.89$. HR-ESI-MS calcd. for $\mathrm{C}_{4} \mathrm{H}_{10} \mathrm{~N}_{4} \mathrm{O}_{2}[\mathrm{M}+\mathrm{H}]^{+}:$147.15, found 147.17.

\section{Synthesis of ethylidene diisocyanate}

The flow system in our work was set up as described in Figure S1.

Solution 1: sodium nitrite $(0.34 \mathrm{~g}, 0.005 \mathrm{~mol})$ was distilled into $50 \mathrm{~mL}$ deionized water.

Solution 2: pure toluene

Solution 3: malonic acid dihydrazide $(0.37 \mathrm{~g}, 0.0025 \mathrm{~mol})$ was dissolved in $50 \mathrm{~mL}$ deionized water and 0.8 $\mathrm{mL}$ aqueous $\mathrm{HCl} 6 \mathrm{~N}$. 
All solutions were pumped with a flow rate of $1 \mathrm{~mL} \mathrm{~min}^{-1}$. The $1.62 \mathrm{~mL}$ coiled reactor was cooled down to $5-10^{\circ} \mathrm{C}$ in a cold bath, resulting in a residence time of $97 \mathrm{~s}$. The outlet then entered the Zaiput separator, which provides continuous separation of the two immiscible liquids, toluene and water. After complete separation, water exited on one side and was collected in a waste Erlenmeyer flask while the organic phase exited on the other side. The organic phase containing the azide product was directly sent to the drying unit with anhydrous sodium sulfate to remove trace water. Finally, the outlet was injected into a second 5 $\mathrm{mL}$ coiled reactor, which was heated to $85{ }^{\circ} \mathrm{C}$ in a sand bath. The outlet containing desired product was placed in an Erlenmeyer flask. After removing solvent, desired product was collected as a pale yellow liquid (71\%) and stored at a temperature of $4{ }^{\circ} \mathrm{C}$.

Ethylidene diisocyanate: ${ }^{1} \mathrm{H}$ NMR $(500 \mathrm{MHz}$, Chloroform- $d$ ) $\delta=7.29(\mathrm{t}, J=7.6,34 \mathrm{H}), 7.20$ (dd, $J=12.1$, 7.3, 49H), $3.51(\mathrm{~s}, 1 \mathrm{H}), 2.39(\mathrm{~s}, 52 \mathrm{H}), 2.04(\mathrm{~d}, J=38.5,2 \mathrm{H}), 1.42-1.18(\mathrm{~m}, 1 \mathrm{H}) .{ }^{13} \mathrm{C}$ NMR $(126 \mathrm{MHz}$, Chloroform- $d$ ) $\delta=138.02,129.19,128.38,125.45,21.60$. HR-ESI-MS calcd. for $\mathrm{C}_{4} \mathrm{H}_{4} \mathrm{~N}_{2} \mathrm{O}_{2}[\mathrm{M}+\mathrm{H}]^{+}$: 113.09, found 113.03

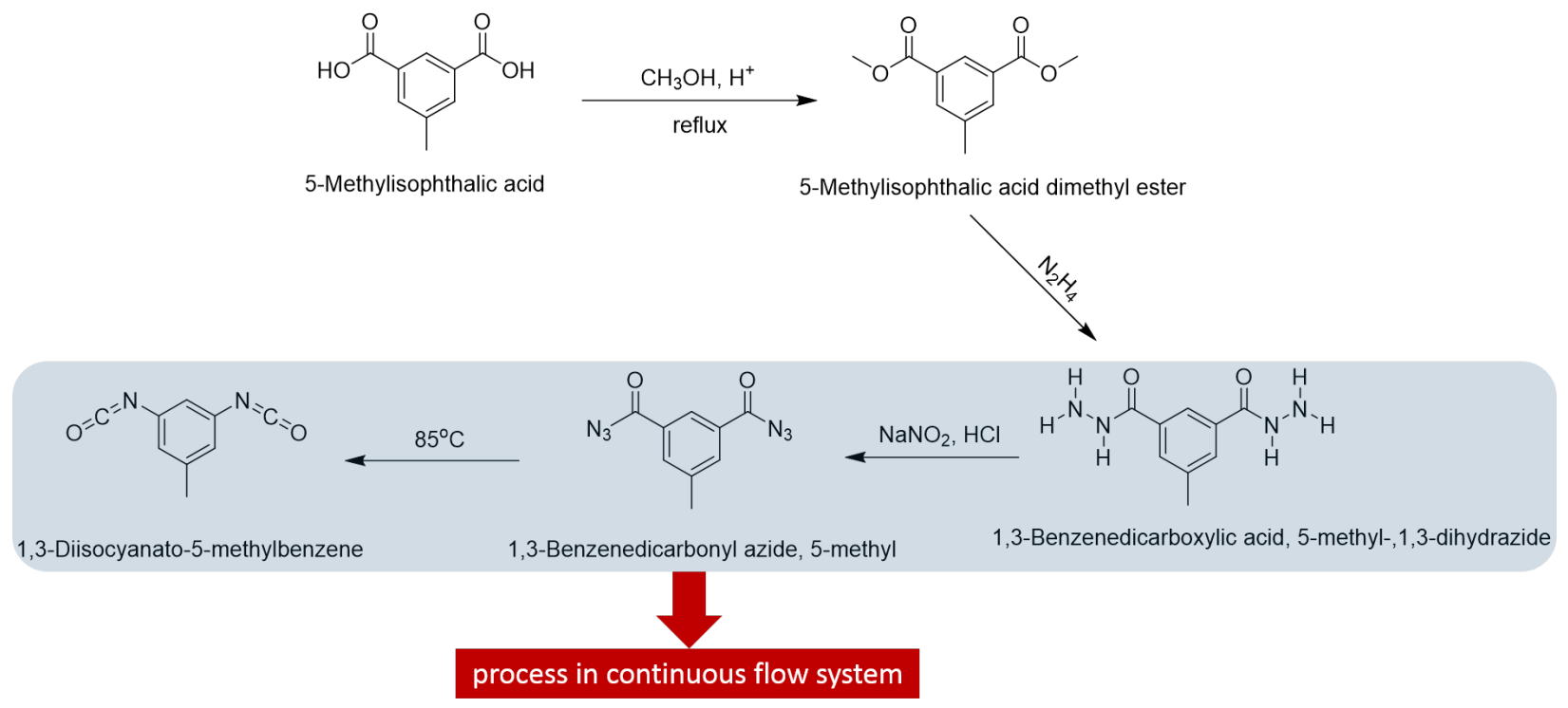

Figure S15: Pathway to synthesize 1,3-diisocyanato-5-methylbenzene

\section{Synthesis of 5-methylisophthalic acid dimethyl ester}

5-Methylisophthalic acid $(0.4 \mathrm{~g}, 0.0022 \mathrm{~mol})$ was added to a $50 \mathrm{~mL}$ one-neck round-bottom flask, then 5 $\mathrm{mL}$ methanolic $\mathrm{HCl} 1 \mathrm{M}$ was poured into this flask. The reaction was reflux for $2 \mathrm{~h}$. Once finishing reaction, $20 \mathrm{~mL}$ hexane was added to the flask. Two layers were divided by separating funnel. The organic layer was dried over anhydrous $\mathrm{Na}_{2} \mathrm{SO}_{4}$, and evaporated to afford desired product as a white powder with the yield of $68 \%$.

5-methylisophthalic acid dimethyl ester: ${ }^{1} \mathrm{H}$ NMR $\left(500 \mathrm{MHz}, \mathrm{DMSO}-d_{6}\right) \delta=8.21(\mathrm{~s}, 1 \mathrm{H}), 7.96(\mathrm{~s}, 2 \mathrm{H})$, $3.83(\mathrm{~s}, 9 \mathrm{H}), 2.38(\mathrm{~s}, 4 \mathrm{H}) .{ }^{13} \mathrm{C}$ NMR $\left(126 \mathrm{MHz}, \mathrm{DMSO}-d_{6}\right) \delta=166.04,139.87,134.53,130.61,127.39$, 52.94, 21.06.

\section{Synthesis of 1,3-Benzenedicarboxylic acid, 5-methyl-,1,3-dihydrazide}

$0.6 \mathrm{~mL} \mathrm{~N}_{2} \mathrm{H}_{4}(0.015 \mathrm{~mol})$ was added slowly to $5 \mathrm{~mL}$ methanol contain $0.3 \mathrm{~g} \mathrm{5}$-methylisophthalic acid dimethyl ester $(0.0014 \mathrm{~mol})$ in $20 \mathrm{~mL}$ one-neck round-bottom flask. The reaction was refluxed for $6 \mathrm{~h}$. After 
cooling down, 1,3-Benzenedicarboxylic acid, 5-methyl-,1,3-dihydrazide (74\% in yield) is collected as a white powder after filtration and washing with methanol.

1,3-Benzenedicarboxylic acid, 5-methyl-,1,3-dihydrazide: ${ }^{1} \mathrm{H}$ NMR (500 MHz, DMSO- $\left.d_{6}\right) \delta=9.71(\mathrm{~s}, 2 \mathrm{H}), 8.01$ $(\mathrm{s}, 1 \mathrm{H}), 7.71(\mathrm{~s}, 2 \mathrm{H}), 4.48(\mathrm{~s}, 4 \mathrm{H}), 3.84(\mathrm{~s}, 0 \mathrm{H}), 2.34(\mathrm{~s}, 3 \mathrm{H}) .{ }^{13} \mathrm{C}$ NMR $\left(126 \mathrm{MHz}, \mathrm{DMSO}-d_{6}\right) \delta=166.13,138.37$, 134.06, 130.48, 123.72, 21.44. HR-ESI-MS calcd. for $\mathrm{C}_{9} \mathrm{H}_{12} \mathrm{~N}_{4} \mathrm{O}_{2}[\mathrm{M}+\mathrm{H}]^{+}:$209.22, found 209.11

\section{Synthesis of 1,3-Diisocyanato-5-methylbenzene}

The flow system in our work was set up as described in Figure S1.

Solution 1: sodium nitrite $(0.34 \mathrm{~g}, 0.005 \mathrm{~mol})$ was distilled into $50 \mathrm{~mL}$ deionized water.

Solution 2: pure toluene

Solution 3: 1,3-Benzenedicarboxylic acid, 5-methyl-,1,3-dihydrazide $(0.52 \mathrm{~g}, 0.0025 \mathrm{~mol})$ was dissolved in $50 \mathrm{~mL}$ deionized water and $0.8 \mathrm{~mL}$ aqueous $\mathrm{HCl} 6 \mathrm{~N}$.

All solutions were pumped with a flow rate of $1 \mathrm{~mL} \mathrm{~min}^{-1}$. The $1.62 \mathrm{~mL}$ coiled reactor was cooled down to $5-10^{\circ} \mathrm{C}$ in a cold bath, resulting in a residence time of $97 \mathrm{~s}$. The outlet then entered the Zaiput separator, which provides continuous separation of the two immiscible liquids, toluene and water. After complete separation, water exited on one side and was collected in a waste Erlenmeyer flask while the organic phase exited on the other side. The organic phase containing the azide product was directly sent to the drying unit with anhydrous sodium sulfate to remove trace water. Finally, the outlet was injected into a second 5 $\mathrm{mL}$ coiled reactor, which was heated to $85{ }^{\circ} \mathrm{C}$ in a sand bath. The outlet containing desired product was placed in an Erlenmeyer flask. After removing solvent, desired product was collected as a colorless liquid $(60 \%)$ and stored at a temperature of $4{ }^{\circ} \mathrm{C}$.

1,3-Diisocyanato-5-methylbenzene: ${ }^{1} \mathrm{H}$ NMR $(500 \mathrm{MHz}$, Chloroform- $d) \delta=8.48(\mathrm{~s}, 1 \mathrm{H}), 8.11(\mathrm{~s}, 3 \mathrm{H}), 7.70$ $(\mathrm{s}, 2 \mathrm{H}), 7.58(\mathrm{~d}, J=8.1,0 \mathrm{H}), 7.57(\mathrm{~s}, 2 \mathrm{H}), 7.29(\mathrm{t}, J=7.5,19 \mathrm{H}), 7.22(\mathrm{~s}, 12 \mathrm{H}), 7.23-7.14(\mathrm{~m}, 19 \mathrm{H}), 6.76(\mathrm{~d}$, $J=1.9,2 \mathrm{H}), 6.64$ (q, $J=2.6,1 \mathrm{H}), 3.96(\mathrm{~d}, J=14.9,1 \mathrm{H}), 3.81(\mathrm{~d}, J=9.1,1 \mathrm{H}), 2.49(\mathrm{~d}, J=8.8,1 \mathrm{H}), 2.49(\mathrm{~s}, 6 \mathrm{H})$, $2.40(\mathrm{~d}, J=7.4,40 \mathrm{H}), 2.32(\mathrm{~d}, J=3.5,4 \mathrm{H}), 1.30(\mathrm{~s}, 1 \mathrm{H}) .{ }^{13} \mathrm{C}$ NMR $(126 \mathrm{MHz}$, Chloroform- $d) \delta=171.78$, 140.52 , 138.00, 135.44, 134.16, 131.43, 131.10, 129.18, 128.37, 127.87, 127.49, 125.45, 125.26, 123.17, 122.80, 118.09, 21.58, 21.22, 21.17. HR-ESI-MS calcd. for $\mathrm{C}_{9} \mathrm{H}_{6} \mathrm{~N}_{2} \mathrm{O}_{2}[\mathrm{M}+\mathrm{H}]^{+}: 175.16$, found 175.15

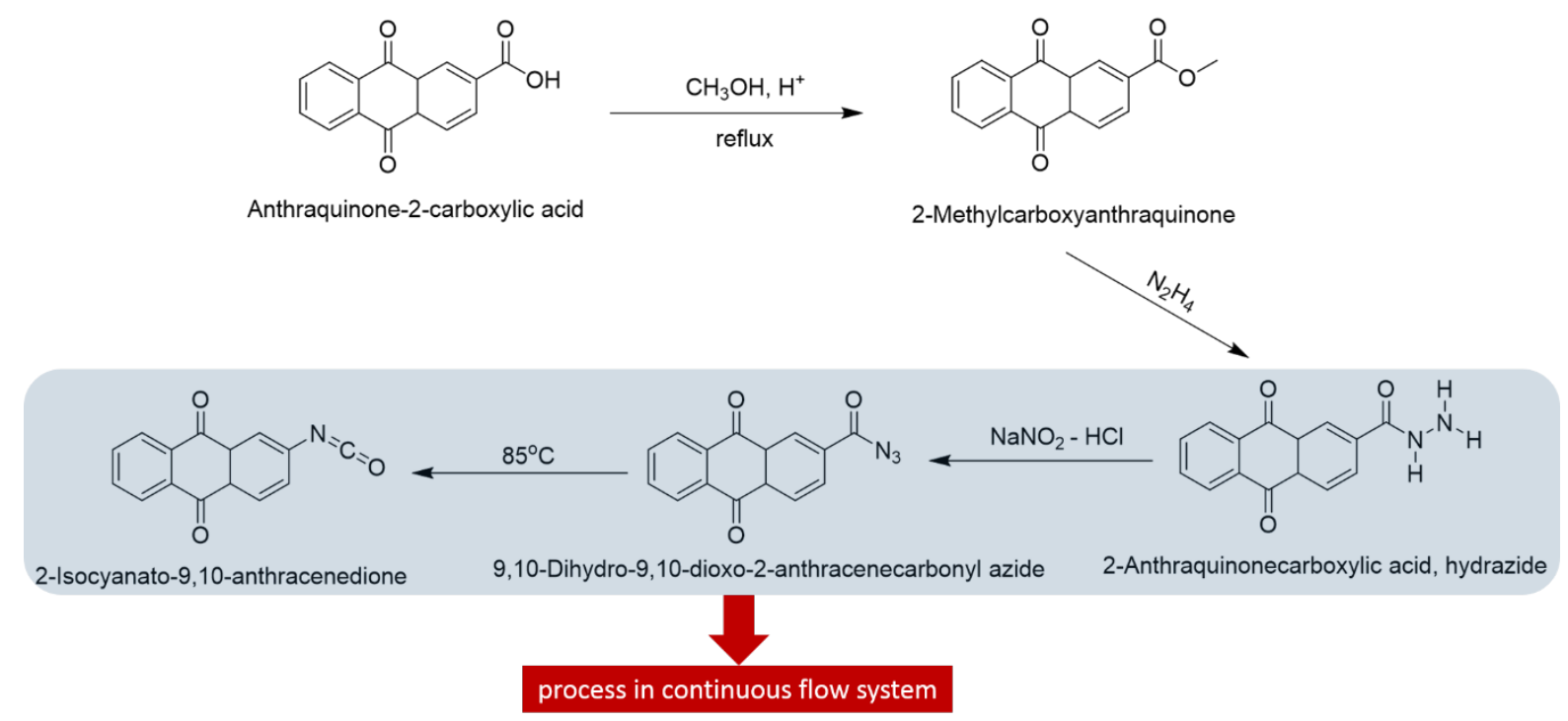

Figure S16. Pathway to synthesize 2-Isocyanato-9,10-anthracenedione 


\section{Synthesis of 2-Methylcarboxyanthraquinone}

Anthraquinone-2-carboxylic acid $(0.3 \mathrm{~g}, 0.0012 \mathrm{~mol})$ was added to a $250 \mathrm{~mL}$ one-neck round-bottom flask, then $4 \mathrm{~mL}$ methanolic $\mathrm{HCl} 1 \mathrm{M}$ was poured into this flask. The reaction was reflux for $2 \mathrm{~h}$. Once finishing reaction, $10 \mathrm{~mL}$ hexane was added to the flask. Two layers were divided by separating funnel. The organic layer was dried over anhydrous $\mathrm{Na}_{2} \mathrm{SO}_{4}$, and evaporated to afford desired product as a white powder with the yield of $80 \%$.

2-Methylcarboxyanthraquinone: ${ }^{1} \mathrm{H}$ NMR $(500 \mathrm{MHz}$, Chloroform- $d$ ) $\delta=8.96(\mathrm{~s}, 1 \mathrm{H}), 8.45(\mathrm{~d}, J=9.2,1 \mathrm{H})$, $8.40(\mathrm{~d}, J=7.8,1 \mathrm{H}), 8.35(\mathrm{~s}, 2 \mathrm{H}), 7.84(\mathrm{~s}, 2 \mathrm{H}), 4.01(\mathrm{~d}, J=6.9,3 \mathrm{H}) .{ }^{13} \mathrm{C}$ NMR $\left(126 \mathrm{MHz}, \mathrm{DMSO}-d_{6}\right) \delta=$ $182.58,182.42$, 166.49, 136.19, 136.06, 135.29, 134.95, 133.65, 133.48, 127.88, 127.68, 127.39.

\section{Synthesis of 2-Anthraquinonecarboxylic acid hydrazide}

$0.28 \mathrm{~mL} \mathrm{~N} \mathrm{~N}_{2} \mathrm{H}_{4}(0.0091 \mathrm{~mol})$ was added slowly to $10 \mathrm{~mL}$ methanol contain $0.242 \mathrm{~g}$ 2methylcarboxyanthraquinone $(0.0009 \mathrm{~mol})$ in $20 \mathrm{~mL}$ one-neck round-bottom flask. The reaction was refluxed for $6 \mathrm{~h}$. After cooling down, desired product ( $77 \%$ in yield) is collected as a yellow powder after filtration and washing with methanol.

2-Anthraquinonecarboxylic acid hydrazide: ${ }^{1} \mathrm{H}$ NMR (500 MHz, DMSO- $\left.d_{6}\right) \delta=10.23(\mathrm{~s}, 1 \mathrm{H}), 8.62(\mathrm{~s}, 2 \mathrm{H})$, $8.27(\mathrm{dd}, J=23.0,6.7,3 \mathrm{H}), 8.23-8.13(\mathrm{~m}, 8 \mathrm{H}), 7.91(\mathrm{~d}, J=7.1,6 \mathrm{H}) .{ }^{13} \mathrm{C}$ NMR $\left(126 \mathrm{MHz}, \mathrm{DMSO}-d_{6}\right) \delta=$ $61.63,127.35,127.99,135.19,153.94,154.26$. HR-ESI-MS calcd. for $\mathrm{C}_{15} \mathrm{H}_{10} \mathrm{~N}_{2} \mathrm{O}_{3}[\mathrm{M}+\mathrm{H}]^{+}: 267.25$, found 267.25

\section{Synthesis of 2-Isocyanato-9,10-anthracenedione}

The flow system in our work was set up as described in Figure S1.

Solution 1: sodium nitrite $(0.34 \mathrm{~g}, 0.005 \mathrm{~mol})$ was distilled into $50 \mathrm{~mL}$ deionized water.

Solution 2: pure toluene

Solution 3: 2-Anthraquinonecarboxylic acid hydrazide $(0.67 \mathrm{~g}, 0.0025 \mathrm{~mol})$ was dissolved in $50 \mathrm{~mL}$ deionized water and $0.8 \mathrm{~mL}$ aqueous $\mathrm{HCl} 6 \mathrm{~N}$.

All solutions were pumped with a flow rate of $1 \mathrm{~mL} \mathrm{~min}^{-1}$. The $1.62 \mathrm{~mL}$ coiled reactor was cooled down to $5-10^{\circ} \mathrm{C}$ in a cold bath, resulting in a residence time of $97 \mathrm{~s}$. The outlet then entered the Zaiput separator, which provides continuous separation of the two immiscible liquids, toluene and water. After complete separation, water exited on one side and was collected in a waste Erlenmeyer flask while the organic phase exited on the other side. The organic phase containing the azide product was directly sent to the drying unit with anhydrous sodium sulfate to remove trace water. Finally, the outlet was injected into a second 5 $\mathrm{mL}$ coiled reactor, which was heated to $85{ }^{\circ} \mathrm{C}$ in a sand bath. The outlet containing desired product was placed in an Erlenmeyer flask. After removing solvent, desired product was collected as a colorless liquid $(61 \%)$ and stored at a temperature of $4{ }^{\circ} \mathrm{C}$.

2-Isocyanato-9,10-anthracenedione: ${ }^{1} \mathrm{H}$ NMR $(500 \mathrm{MHz}$, Chloroform- $d$ ) $\delta=7.31-7.25(\mathrm{~m}, 4 \mathrm{H}), 7.19$ (dd, $J=12.4,7.2,6 \mathrm{H}), 3.50(\mathrm{~s}, 0 \mathrm{H}), 2.38(\mathrm{~s}, 5 \mathrm{H}), 1.62(\mathrm{~s}, 1 \mathrm{H}) .{ }^{13} \mathrm{C}$ NMR $(126 \mathrm{MHz}$, Chloroform- $d$ ) $\delta=138.01$, 129.18, 128.37, 125.44, 21.59. HR-ESI-MS calcd. for $\mathrm{C}_{15} \mathrm{H}_{7} \mathrm{NO}_{3}[\mathrm{M}+\mathrm{H}]^{+}: 250.22$, found 250.20 


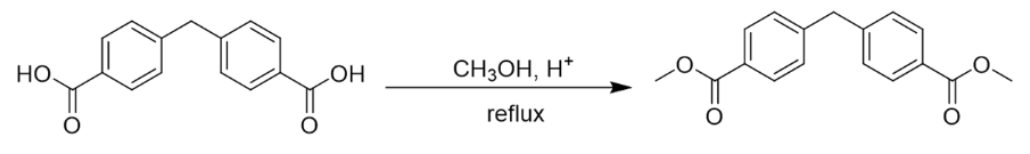

diphenylmethane-4,4'-dicarboxylic acid dimethyl 4,4'-methylenebis(benzoate)

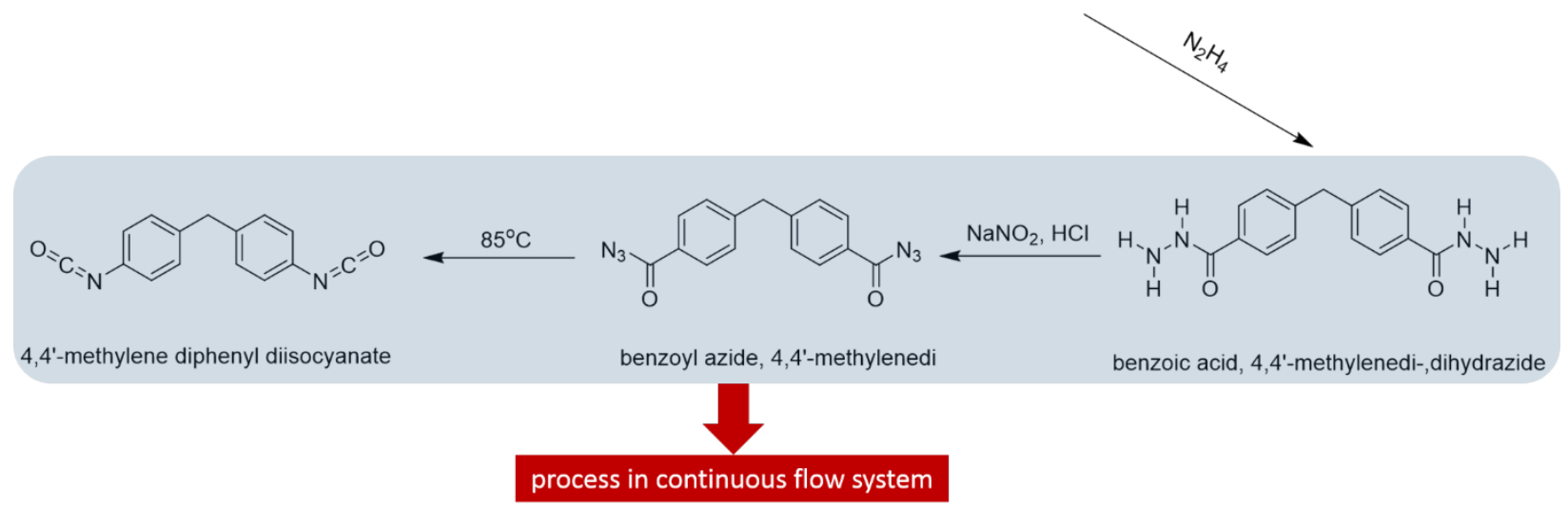

Figure S17: Pathway to synthesize 4,4'-methylene diphenyl diisocyanate

\section{Synthesis of Dimethyl 4,4'-methylenebis(benzoate)}

Diphenylmethane-4,4'-dicarboxylic acid $(0.41 \mathrm{~g}, 0.0016 \mathrm{~mol})$ was added to a $20 \mathrm{~mL}$ one-neck round-bottom flask, then $5 \mathrm{~mL}$ methanolic $\mathrm{HCl} 1 \mathrm{M}$ was poured into this flask. The reaction was reflux for $2 \mathrm{~h}$. Once finishing reaction, $10 \mathrm{~mL}$ hexane was added to the flask. Two layers were divided by separating funnel. The organic layer was dried over anhydrous $\mathrm{Na}_{2} \mathrm{SO}_{4}$, and evaporated to afford desired product as a white product with the yield of $78 \%$.

Dimethyl 4,4'-methylenebis(benzoate): ${ }^{1} \mathrm{H}$ NMR (500 MHz, DMSO- $\left.d_{6}\right) \delta=7.86(\mathrm{~d}, J=8.0,2 \mathrm{H}), 7.36(\mathrm{~d}$, $J=8.0,2 \mathrm{H}), 4.08(\mathrm{~s}, 1 \mathrm{H}), 3.79(\mathrm{~s}, 3 \mathrm{H}) .{ }^{13} \mathrm{C}$ NMR $\left(126 \mathrm{MHz}, \mathrm{DMSO}-d_{6}\right) \delta=166.64,146.69,130.03,129.74$, $128.21,52.60,41.23$.

\section{Synthesis of Benzoic acid 4,4'-methylenedi-dihydrazide}

$0.5 \mathrm{~mL} \mathrm{~N} \mathrm{H}_{4}(0.008 \mathrm{~mol})$ was added slowly to $8 \mathrm{~mL}$ methanol contain $0.21 \mathrm{~g}$ dimethyl 4,4'methylenebis(benzoate) $(0.05 \mathrm{~mol})$ in $20 \mathrm{~mL}$ one-neck round-bottom flask. The reaction was refluxed for $6 \mathrm{~h}$. After cooling down, desired product ( $88 \%$ in yield) is collected as a light yellow powder after filtration and washing with methanol.

Benzoic acid 4,4'-methylenedi-dihydrazide: ${ }^{1} \mathrm{H}$ NMR $\left(500 \mathrm{MHz}, \mathrm{DMSO}-d_{6}\right) \delta=9.67(\mathrm{~s}, 1 \mathrm{H}), 7.86(\mathrm{~d}$, $J=7.8,8 \mathrm{H}), 7.77(\mathrm{~d}, J=7.7,1 \mathrm{H}), 7.71(\mathrm{~d}, J=7.7,2 \mathrm{H}), 7.36(\mathrm{~d}, J=7.9,7 \mathrm{H}), 7.28(\mathrm{~d}, J=7.6,4 \mathrm{H}), 4.08(\mathrm{~s}, 2 \mathrm{H})$, $4.04(\mathrm{~d}, J=3.8,2 \mathrm{H}), 3.79(\mathrm{~s}, 10 \mathrm{H}) .{ }^{13} \mathrm{C}$ NMR $\left(126 \mathrm{MHz}, \mathrm{DMSO}-d_{6}\right) \delta=166.65,146.70,130.04,128.20$, 52.60, 41.22. HR-ESI-MS calcd. for $\mathrm{C}_{15} \mathrm{H}_{16} \mathrm{~N}_{4} \mathrm{O}_{2}[\mathrm{M}+\mathrm{H}]^{+}: 285.31$, found 285.22

\section{Synthesis of 4,4'-methylene diphenyl diisocyanate}

The flow system in our work was set up as described in Figure S1.

Solution 1: sodium nitrite $(0.34 \mathrm{~g}, 0.005 \mathrm{~mol})$ was distilled into $50 \mathrm{~mL}$ deionized water.

Solution 2: pure toluene

Solution 3: Benzoic acid 4,4'-methylenedi-dihydrazide $(0.71 \mathrm{~g}, 0.0025 \mathrm{~mol})$ was dissolved in $50 \mathrm{~mL}$ deionized water and $0.8 \mathrm{~mL}$ aqueous $\mathrm{HCl} 6 \mathrm{~N}$.

All solutions were pumped with a flow rate of $1 \mathrm{~mL} \mathrm{~min}^{-1}$. The $1.62 \mathrm{~mL}$ coiled reactor was cooled down to $5-10^{\circ} \mathrm{C}$ in a cold bath, resulting in a residence time of $97 \mathrm{~s}$. The outlet then entered the Zaiput separator, which provides continuous separation of the two immiscible liquids, toluene and water. After complete 
separation, water exited on one side and was collected in a waste Erlenmeyer flask while the organic phase exited on the other side. The organic phase containing the azide product was directly sent to the drying unit with anhydrous sodium sulfate to remove trace water. Finally, the outlet was injected into a second 5 $\mathrm{mL}$ coiled reactor, which was heated to $85{ }^{\circ} \mathrm{C}$ in a sand bath. The outlet containing desired product was placed in an Erlenmeyer flask. After removing solvent, desired product was collected as a white powder (58\%) and stored at a temperature of $4{ }^{\circ} \mathrm{C}$.

4,4'-methylene diphenyl diisocyanate: ${ }^{1} \mathrm{H}$ NMR $(500 \mathrm{MHz}$, Chloroform- $d$ ) $\delta=7.10(\mathrm{~d}, J=8.3,2 \mathrm{H}), 7.01(\mathrm{~d}$, $J=7.9,2 \mathrm{H}), 3.92(\mathrm{~s}, 1 \mathrm{H}) .{ }^{13} \mathrm{C}$ NMR $(126 \mathrm{MHz}$, Chloroform- $d$ ) $\delta=138.43,131.65,130.04,124.94,124.74$, 40.79. HR-ESI-MS calcd. for $\mathrm{C}_{15} \mathrm{H}_{10} \mathrm{~N}_{2} \mathrm{O}_{2}[\mathrm{M}+2 \mathrm{MeOH}+\mathrm{Na}]^{+}: 337.33$, found 337.19

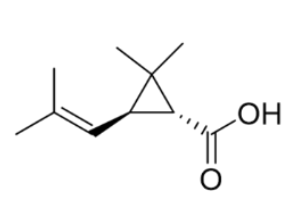

Chrysanthemic acid

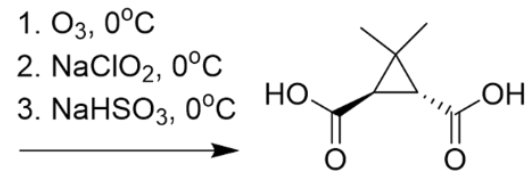

3,3-dimethyl-

1,2-cyclopropanedicarboxylic acid 3,3-dimethyl-1,2-cyclopropanedicarboxylic acid -1,2-dimethyl ester
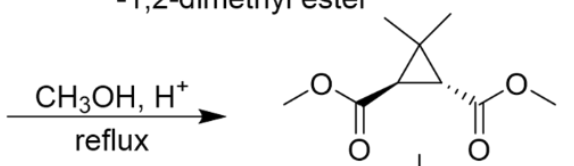

$\mathrm{N}_{2} \mathrm{H}_{4}$

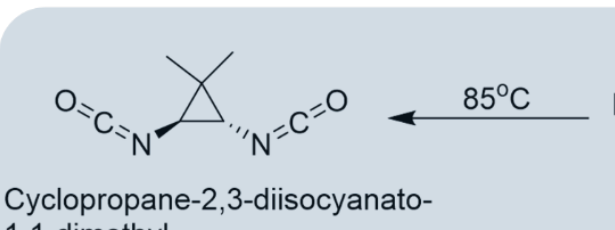

1,1-dimethyl

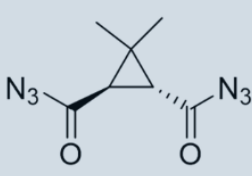

not isolated

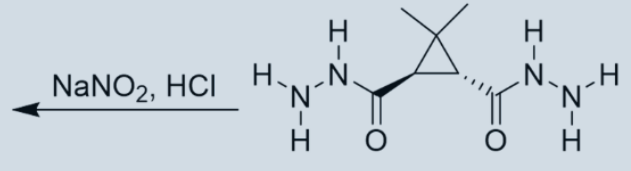

1,2-cyclopropanedicarboxylic acid3,3-dimethyl-1,2-dihydrazide

\section{process in continuous flow system}

Figure S18: Pathway to synthesize 1,1-dimethyl-2,3-diisocyanato cyclopropane from chrysanthemic acid

\section{Synthesis of 3,3-dimethyl-1,2-cyclopropanedicarboxylic acid:}

The system for ozonolysis in batch mode is described in Figure S4. A solution of chrysanthemic acid ( 0.3 $\mathrm{g}, 0.0017 \mathrm{~mol}, 1$ equiv) dissolved in $6 \mathrm{~mL}$ acetonitrile and $0.6 \mathrm{~mL} \mathrm{H}_{2} \mathrm{O}$ was added to a $20 \mathrm{~mL}$ round-bottom flask. The solution was cooled to $0{ }^{\circ} \mathrm{C}$ in an ice bath and exposed to ozone. Complete reaction can be verified by thin-layer chromatography (TLC). Once the ozonolysis was completed, a $3.6 \mathrm{~mL} 2 \mathrm{M}$ aqueous solution of $\mathrm{NaClO}_{2}(0.8 \mathrm{~g}, 0.0071 \mathrm{~mol}, 4$ equiv $)$ was slowly added to the cold reaction. The internal reaction temperature should be under $15{ }^{\circ} \mathrm{C}$ during the portion-wise adding of $\mathrm{NaClO}_{2}$. The reaction mixture turned yellow after adding $\mathrm{NaClO}_{2}$ solution. The mixture was then stirred overnight. Next, $3.9 \mathrm{~mL} 2 \mathrm{M}$ aqueous solution of sodium bisulfite ( $0.81 \mathrm{~g}, 0.0078 \mathrm{~mol}, 4$ equiv) was added dropwise to the reaction mixture maintaining the temperature under $15{ }^{\circ} \mathrm{C}$. The solution turned clear after the solution of sodium bisulfite was completely added. The mixture was stirred for $10 \mathrm{~min}$. Ethyl acetate $(15 \mathrm{~mL})$ was poured into the mixture, and the two layers were separated. The organic phase was collected, and solvent removed to provide a white slurry, which was a mixture of 3,3-dimethyl-1,2-cyclopropanedicarboxylic acid and isobutyric acid. Hot water and hexane were used to separate 3,3-dimethyl-1,2-cyclopropanedicarboxylic acid and isobutyric acid. On cooling the aqueous phase, 3,3-dimethyl-1,2-cyclopropanedicarboxylic acid was formed as a white crystal after being filtered, cleaned several times with cold water and dried. The 
hexane layer containing isobutyric acid was then dried over $\mathrm{Na}_{2} \mathrm{SO}_{4}$, filtered, and concentrated to obtain an colorless liquid. The yields of 3,3-dimethyl-1,2-cyclopropanedicarboxylic acid and isobutyric acid were $80 \%$ and $78 \%$, respectively.

3,3-dimethyl-1,2-cyclopropanedicarboxylic acid: ${ }^{1} \mathrm{H}$ NMR $\left(500 \mathrm{MHz}, \mathrm{DMSO}-d_{6}\right) \delta=12.41(\mathrm{~s}, 1 \mathrm{H}), 1.89$ $(\mathrm{s}, 1 \mathrm{H}), 1.19(\mathrm{~s}, 3 \mathrm{H}) .{ }^{13} \mathrm{C}$ NMR $\left(126 \mathrm{MHz}, \mathrm{DMSO}-d_{6}\right) \delta=171.77,33.63,29.55,20.74,20.65$. HR-ESI-MS calcd. for $\mathrm{C}_{7} \mathrm{H}_{10} \mathrm{O}_{4}[\mathrm{M}-\mathrm{H}]-:$ : 157.15 , found 157.17

Synthesis of 3,3-dimethyl-1,2-cyclopropanedicarboxylic acid-1,2-dimethyl ester:

3,3-dimethyl-1,2-cyclopropanedicarboxylic acid $(0.26 \mathrm{~g}, 0.0016 \mathrm{~mol})$ was added to a $20 \mathrm{~mL}$ one-neck round-bottom flask, then $5 \mathrm{~mL}$ methanolic $\mathrm{HCl} 1 \mathrm{M}$ was poured into this flask. The reaction was reflux for $2 \mathrm{~h}$. Once finishing reaction, $10 \mathrm{~mL}$ hexane was added to the flask. Two layers were divided by separating funnel. The organic layer was dried over anhydrous $\mathrm{Na}_{2} \mathrm{SO}_{4}$, and evaporated to afford desired product as a colorless oil with the yield of $79 \%$.

3,3-dimethyl-1,2-cyclopropanedicarboxylic acid-1,2-dimethyl ester: ${ }^{1} \mathrm{H}$ NMR $(500 \mathrm{MHz}$, Chloroform- $d) \delta=$ $3.89(\mathrm{~d}, J=15.6,1 \mathrm{H}), 3.70(\mathrm{~d}, J=15.9,2 \mathrm{H}), 3.65(\mathrm{~s}, 80 \mathrm{H}), 1.40(\mathrm{~s}, 1 \mathrm{H}), 1.25(\mathrm{~s}, 86 \mathrm{H}), 1.21(\mathrm{~s}, 2 \mathrm{H}), 0.80(\mathrm{~s}, 1 \mathrm{H}) .{ }^{13} \mathrm{C}$ NMR (126 MHz, Chloroform- $d$ ) $\delta=170.93,51.94,33.58,30.47,20.44$.

\section{Synthesis of 1,2-cyclopropanedicarboxylic acid-3,3-dimethyl-1,2-dihydrazide}

$0.6 \mathrm{~mL} \mathrm{~N} \mathrm{~N}_{2} \mathrm{H}_{4}(0.017 \mathrm{~mol})$ was added slowly to $15 \mathrm{~mL}$ methanol contain $0.33 \mathrm{~g} \mathrm{3,3-dimethyl-1,2-}$ cyclopropanedicarboxylic acid-1,2-dimethyl ester $(0.0017 \mathrm{~mol})$ in $150 \mathrm{~mL}$ one-neck round-bottom flask. The reaction was refluxed for $6 \mathrm{~h}$. After cooling down, desired product ( $88 \%$ in yield) is collected as a white powder after filtration and washing with methanol.

1,2-cyclopropanedicarboxylic acid-3,3-dimethyl-1,2-dihydrazide: ${ }^{1} \mathrm{H}$ NMR (500 MHz, DMSO- $\left.d_{6}\right) \delta=9.13$ $(\mathrm{s}, 1 \mathrm{H}), 4.14(\mathrm{~s}, 2 \mathrm{H}), 1.92(\mathrm{~s}, 1 \mathrm{H}), 1.11(\mathrm{~s}, 3 \mathrm{H}) .{ }^{13} \mathrm{C}$ NMR $\left(126 \mathrm{MHz}, \mathrm{DMSO}-d_{6}\right) \delta=169.48,31.62,27.64$, 20.61. HR-ESI-MS calcd. for $\mathrm{C}_{7} \mathrm{H}_{14} \mathrm{~N}_{4} \mathrm{O}_{2}[\mathrm{M}+\mathrm{Na}]^{+}: 209.19$, found 209.22

\section{Synthesis of cyclopropane-2,3-diisocyanato-1,1-dimethyl:}

The flow system in our work was set up as described in Figure S1.

Solution 1: sodium nitrite $(0.34 \mathrm{~g}, 0.005 \mathrm{~mol})$ was distilled into $50 \mathrm{~mL}$ deionized water.

Solution 2: pure toluene

Solution 3: 1,2-cyclopropanedicarboxylic acid-3,3-dimethyl-1,2-dihydrazide $(0.46 \mathrm{~g}, 0.0025 \mathrm{~mol})$ was dissolved in $50 \mathrm{~mL}$ deionized water and $0.8 \mathrm{~mL}$ aqueous $\mathrm{HCl} 6 \mathrm{~N}$.

All solutions were pumped with a flow rate of $1 \mathrm{~mL} \mathrm{~min}^{-1}$. The $1.62 \mathrm{~mL}$ coiled reactor was cooled down to $5-10^{\circ} \mathrm{C}$ in a cold bath, resulting in a residence time of $97 \mathrm{~s}$. The outlet then entered the Zaiput separator, which provides continuous separation of the two immiscible liquids, toluene and water. After complete separation, water exited on one side and was collected in a waste Erlenmeyer flask while the organic phase exited on the other side. The organic phase containing the azide product was directly sent to the drying unit with anhydrous sodium sulfate to remove trace water. Finally, the outlet was injected into a second 5 $\mathrm{mL}$ coiled reactor, which was heated to $85{ }^{\circ} \mathrm{C}$ in a sand bath. The outlet containing desired product was placed in an Erlenmeyer flask. After removing solvent, desired product was collected as a colorless liquid $(57 \%)$ and stored at a temperature of $4{ }^{\circ} \mathrm{C}$.

Cyclopropane-2,3-diisocyanato-1,1-dimethyl: ${ }^{1} \mathrm{H}$ NMR $(500 \mathrm{MHz}$, Chloroform- $d$ ) $\delta=7.30(\mathrm{t}, J=7.6,2 \mathrm{H}), 7.23-$ $7.17(\mathrm{~m}, 2 \mathrm{H}), 2.64(\mathrm{~s}, 1 \mathrm{H}), 2.40(\mathrm{~s}, 3 \mathrm{H}), 1.41-1.21(\mathrm{~m}, 1 \mathrm{H}), 1.20(\mathrm{~s}, 3 \mathrm{H}) .{ }^{13} \mathrm{C}$ NMR $(126 \mathrm{MHz}, \mathrm{Chloroform}-d) \delta=$ $138.01,129.19,128.43,128.38,125.46,125.42,122.00,42.09$, 42.02, 41.98, 24.89, 21.60, 21.56, 19.11, 19.06. HRESI-MS calcd. for $\mathrm{C}_{7} \mathrm{H}_{8} \mathrm{~N}_{2} \mathrm{O}_{2}[\mathrm{M}+\mathrm{MeOH}+\mathrm{Na}]^{+}: 239.23$, found 239.24 

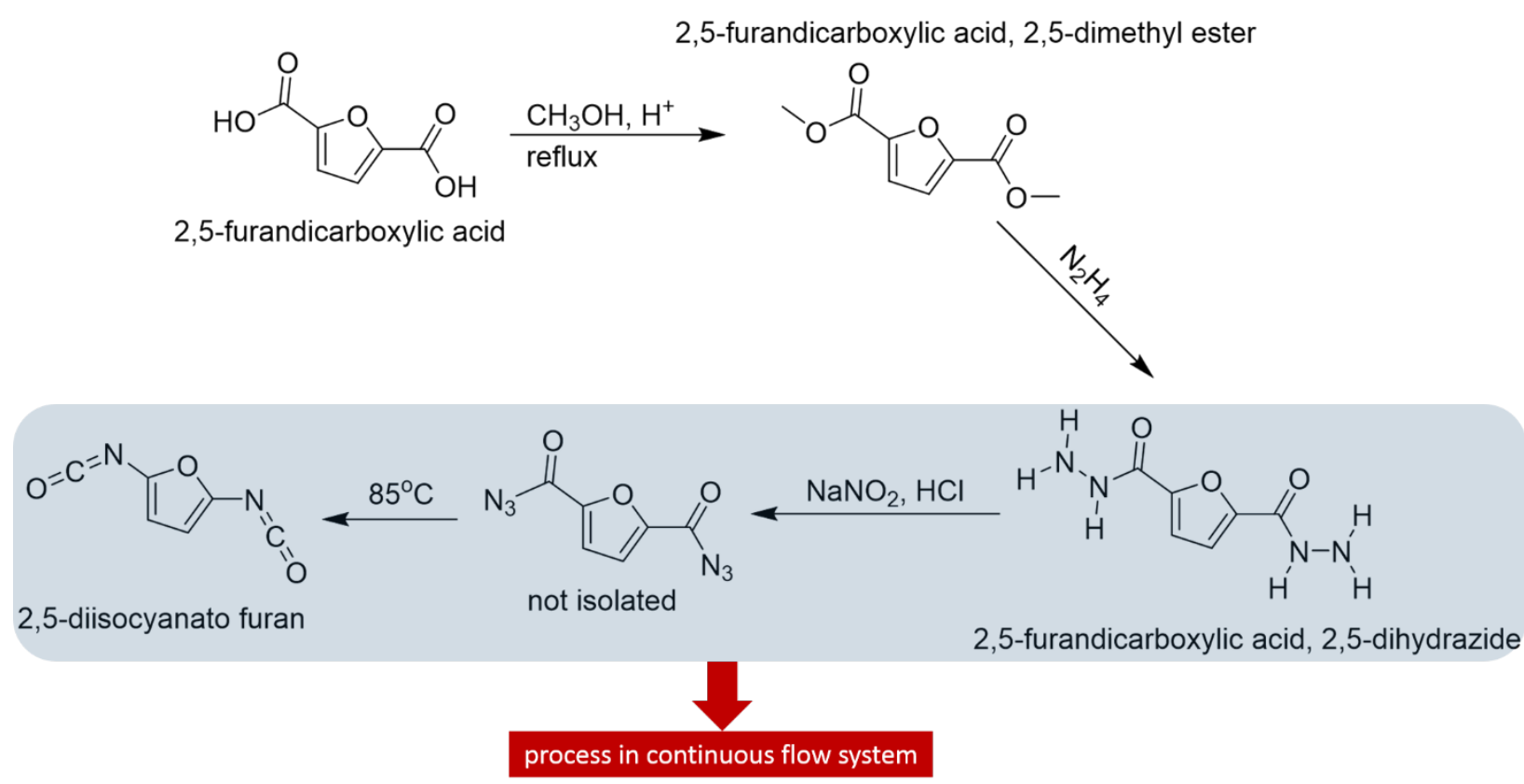

Figure S19: Pathway to synthesize 2,5-diisocyanato furan from 2,5-furandicarboxylic acid

\section{Synthesis of 2,5-furandicarboxylic acid, 2,5-dimethyl ester}

2,5-furandicarboxylic acid $(1.67 \mathrm{~g}, 0.011 \mathrm{~mol})$ was added to a $50 \mathrm{~mL}$ one-neck round-bottom flask, then 20 $\mathrm{mL}$ methanolic $\mathrm{HCl} 1 \mathrm{M}$ was poured into this flask. The reaction was reflux for $2 \mathrm{~h}$. Once finishing reaction, $100 \mathrm{~mL}$ hexane was added to the flask. Two layers were divided by separating funnel. The organic layer was dried over anhydrous $\mathrm{Na}_{2} \mathrm{SO}_{4}$, and evaporated to afford desired product as a white powder with the yield of $59 \%$.

2,5-furandicarboxylic acid, 2,5-dimethyl ester: ${ }^{1} \mathrm{H}$ NMR (500 MHz, DMSO- $\left.d_{6}\right) \delta=7.42-7.34(\mathrm{~m}, 4 \mathrm{H})$, $7.31-7.24(\mathrm{~m}, 2 \mathrm{H}), 3.82(\mathrm{~d}, J=4.0,12 \mathrm{H}), 3.34(\mathrm{~s}, 2 \mathrm{H}), 2.47(\mathrm{~d}, J=5.2,1 \mathrm{H}) .{ }^{13} \mathrm{C}$ NMR $(126 \mathrm{MHz}, \mathrm{DMSO}-$ $\left.d_{6}\right) \delta=159.34,158.39,147.94,146.57,146.21,119.64,52.94$.

\section{Synthesis of 2,5-furandicarboxylic acid, 2,5-dihydrazide}

$2.5 \mathrm{~mL} \mathrm{~N}_{2} \mathrm{H}_{4}(0.08 \mathrm{~mol})$ was added slowly to $25 \mathrm{~mL}$ methanol contain $1.49 \mathrm{~g} \mathrm{2,5-furandicarboxylic} \mathrm{acid,}$ 2,5-dimethyl ester $(0.008 \mathrm{~mol})$ in $150 \mathrm{~mL}$ one-neck round-bottom flask. The reaction was refluxed for $6 \mathrm{~h}$. After cooling down, desired product ( $74 \%$ in yield) is collected as a light pink powder after filtration and washing with methanol.

2,5-furandicarboxylic acid, 2,5-dihydrazide: ${ }^{1} \mathrm{H}$ NMR $\left(500 \mathrm{MHz}, \mathrm{DMSO}-d_{6}\right) \delta=7.07(\mathrm{~s}, 1 \mathrm{H}), 6.98(\mathrm{~d}$, $J=3.4,1 \mathrm{H}), 6.68(\mathrm{~d}, J=3.4,1 \mathrm{H}), 3.34(\mathrm{~s}, 1 \mathrm{H}) .{ }^{13} \mathrm{C}$ NMR $\left(126 \mathrm{MHz}, \mathrm{DMSO}-d_{6}\right) \delta=157.44,147.74,115.13$, 114.06, 113.86. HR-ESI-MS calcd. for $\mathrm{C}_{6} \mathrm{H}_{8} \mathrm{~N}_{4} \mathrm{O}_{3}[\mathrm{M}+\mathrm{H}]^{+}$: 185.15, found 185.16

\section{Synthesis of 2,5-diisocyanato furan}

The flow system in our work was set up as described in Figure S1.

Solution 1: sodium nitrite $(0.34 \mathrm{~g}, 0.005 \mathrm{~mol})$ was distilled into $50 \mathrm{~mL}$ deionized water.

Solution 2: pure toluene

Solution 3: 2,5-furandicarboxylic acid, 2,5-dihydrazide $(0.46 \mathrm{~g}, 0.0025 \mathrm{~mol})$ was dissolved in $50 \mathrm{~mL}$ deionized water and $0.8 \mathrm{~mL}$ aqueous $\mathrm{HCl} 6 \mathrm{~N}$.

All solutions were pumped with a flow rate of $1 \mathrm{~mL} \mathrm{~min}^{-1}$. The $1.62 \mathrm{~mL}$ coiled reactor was cooled down to $5-10^{\circ} \mathrm{C}$ in a cold bath, resulting in a residence time of $97 \mathrm{~s}$. The outlet then entered the Zaiput separator, 
which provides continuous separation of the two immiscible liquids, toluene and water. After complete separation, water exited on one side and was collected in a waste Erlenmeyer flask while the organic phase exited on the other side. The organic phase containing the azide product was directly sent to the drying unit with anhydrous sodium sulfate to remove trace water. Finally, the outlet was injected into a second 5 $\mathrm{mL}$ coiled reactor, which was heated to $85{ }^{\circ} \mathrm{C}$ in a sand bath. The outlet containing desired product was placed in an Erlenmeyer flask. After removing solvent, desired product was collected as a colorless liquid (71\%) and stored at a temperature of $4{ }^{\circ} \mathrm{C}$.

2,5-diisocyanato furan: ${ }^{1} \mathrm{H}$ NMR $(500 \mathrm{MHz}$, Chloroform- $d) \delta=7.41-7.35(\mathrm{~m}, 1 \mathrm{H}), 7.31-7.20(\mathrm{~m}, 4 \mathrm{H})$, $7.20-7.12(\mathrm{~m}, 3 \mathrm{H}), 5.32(\mathrm{~d}, J=3.9,1 \mathrm{H}), 5.11(\mathrm{~s}, 4 \mathrm{H}), 4.12(\mathrm{q}, J=7.0,1 \mathrm{H}), 2.36(\mathrm{~s}, 2 \mathrm{H}), 2.05(\mathrm{~s}, 2 \mathrm{H}), 2.00$ $(\mathrm{s}, 2 \mathrm{H}), 1.37-1.23(\mathrm{~m}, 6 \mathrm{H}), 0.92-0.82(\mathrm{~m}, 1 \mathrm{H}) .{ }^{13} \mathrm{C}$ NMR $(126 \mathrm{MHz}$, Chloroform- $d$ ) $\delta=162.39,148.46$, $137.99,129.15,128.34,126.71,125.41,120.19,119.35,31.71,22.77,21.56,14.24$. HR-ESI-MS calcd. for $\mathrm{C}_{6} \mathrm{H}_{2} \mathrm{~N}_{2} \mathrm{O}_{3}[\mathrm{M}+\mathrm{MeOH}+\mathrm{H}]^{+}$: 183.13 , found 183.04

1-adamantanecarboxylic acid Methyl adamantane-1-carboxylate

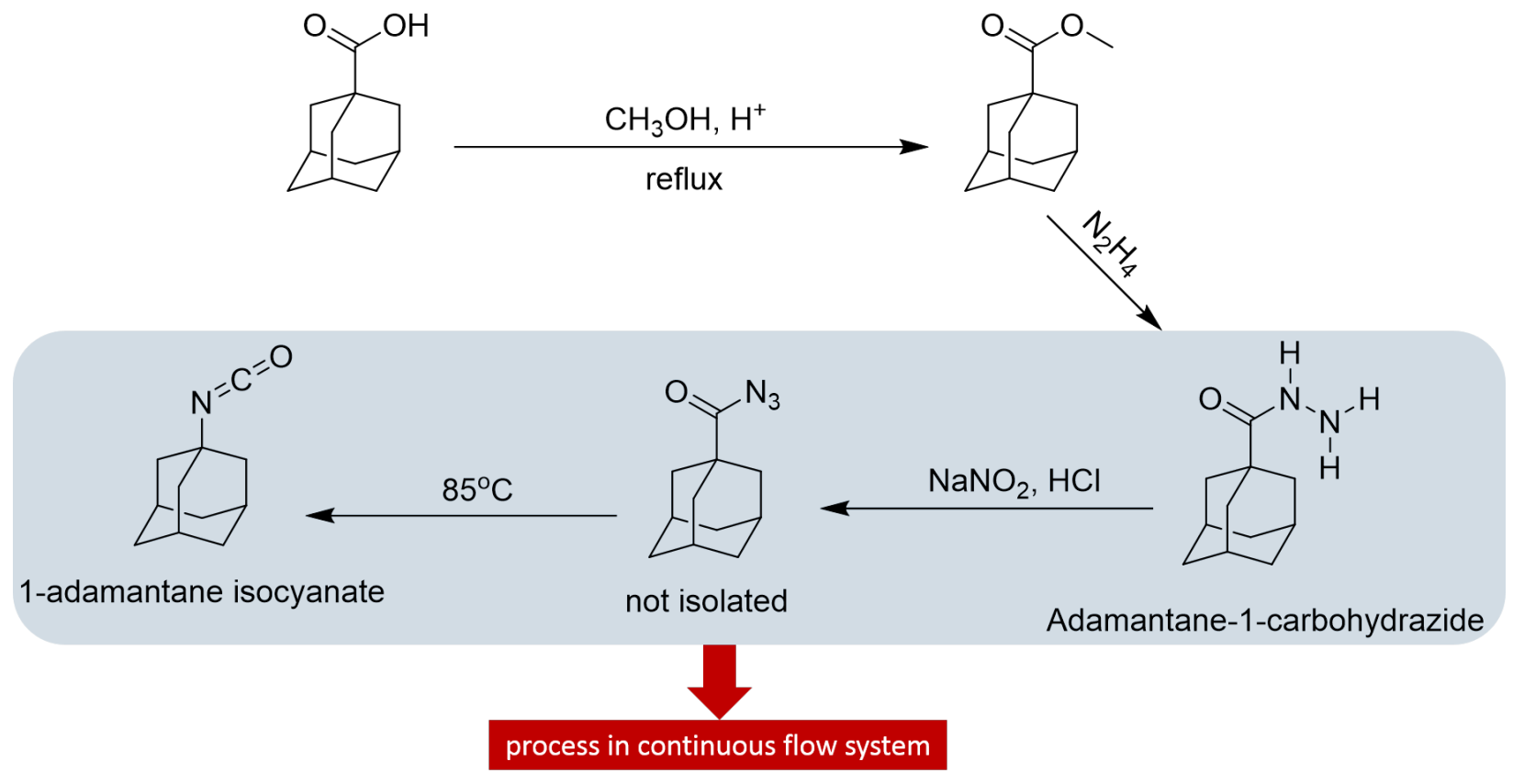

Figure S20: Pathway to synthesize 1-adamantane isocyanate from 1-adamantanecarboxylic acid

\section{Synthesis of methyl adamantine-1-carboxylate:}

1-adamantanecarboxylic acid $(3.00 \mathrm{~g}, 0.016 \mathrm{~mol})$ was added to a $50 \mathrm{~mL}$ one-neck round-bottom flask, then $20 \mathrm{~mL}$ methanolic $\mathrm{HCl} 1 \mathrm{M}$ was poured into this flask. The reaction was reflux for $2 \mathrm{~h}$. Once finishing reaction, $100 \mathrm{~mL}$ hexane was added to the flask. Two layers were divided by separating funnel. The organic layer was dried over anhydrous $\mathrm{Na}_{2} \mathrm{SO}_{4}$, and evaporated to afford desired product as a colorless crystal with the yield of $75 \%$.

Methyl adamantine-1-carboxylate: ${ }^{1} \mathrm{H}$ NMR $(500 \mathrm{MHz}$, Chloroform- $d$ ) $\delta=3.63(\mathrm{~s}, 1 \mathrm{H}), 1.99$ (q, $J=3.3$, $1 \mathrm{H}), 1.87(\mathrm{~d}, J=3.1,2 \mathrm{H}), 1.75-1.65(\mathrm{~m}, 2 \mathrm{H}) .{ }^{13} \mathrm{C}$ NMR $(126 \mathrm{MHz}$, Chloroform- $d$ ) $\delta=178.34,51.64$, $38.94,36.58,28.02$. 


\section{Synthesis of Adamantane-1-carbohydrazide:}

$3.6 \mathrm{~mL} \mathrm{~N} \mathrm{H}_{4}(0.12 \mathrm{~mol})$ was added slowly to $25 \mathrm{~mL}$ methanol contain $2.26 \mathrm{~g}$ methyl adamantine-1carboxylate $(0.012 \mathrm{~mol})$ in $50 \mathrm{~mL}$ one-neck round-bottom flask. The reaction was refluxed for $6 \mathrm{~h}$. After cooling down, desired product ( $75 \%$ in yield) is collected as a white powder after filtration and washing with methanol.

Adamantane-1-carbohydrazide: ${ }^{1} \mathrm{H}$ NMR $\left(500 \mathrm{MHz}, \mathrm{DMSO}-d_{6}\right) \delta=8.65$ (s, 0H), $3.54(\mathrm{~s}, 1 \mathrm{H}), 1.93(\mathrm{p}$, $J=3.1,1 \mathrm{H}), 1.77(\mathrm{~d}, J=3.0,2 \mathrm{H}), 1.69-1.57(\mathrm{~m}, 2 \mathrm{H}) .{ }^{13} \mathrm{C}$ NMR $\left(126 \mathrm{MHz}, \mathrm{DMSO}-d_{6}\right) \delta=177.50,51.91$, 38.93, 36.43, 27.83. HR-ESI-MS calcd. for $\mathrm{C}_{11} \mathrm{H}_{18} \mathrm{~N}_{2} \mathrm{O}[\mathrm{M}+\mathrm{H}]^{+}: 195.27$, found 195.26

\section{Synthesis of 1-adamantane isocyanate:}

The flow system in our work was set up as described in Figure S1.

Solution 1: sodium nitrite $(0.34 \mathrm{~g}, 0.005 \mathrm{~mol})$ was distilled into $50 \mathrm{~mL}$ deionized water.

Solution 2: pure toluene

Solution 3: Adamantane-1-carbohydrazide $(0.48 \mathrm{~g}, 0.0025 \mathrm{~mol})$ was dissolved in $50 \mathrm{~mL}$ deionized water and $0.8 \mathrm{~mL}$ aqueous $\mathrm{HCl} 6 \mathrm{~N}$.

All solutions were pumped with a flow rate of $1 \mathrm{~mL} \mathrm{~min}^{-1}$. The $1.62 \mathrm{~mL}$ coiled reactor was cooled down to $5-10^{\circ} \mathrm{C}$ in a cold bath, resulting in a residence time of $97 \mathrm{~s}$. The outlet then entered the Zaiput separator, which provides continuous separation of the two immiscible liquids, toluene and water. After complete separation, water exited on one side and was collected in a waste Erlenmeyer flask while the organic phase exited on the other side. The organic phase containing the azide product was directly sent to the drying unit with anhydrous sodium sulfate to remove trace water. Finally, the outlet was injected into a second 5 $\mathrm{mL}$ coiled reactor, which was heated to $85^{\circ} \mathrm{C}$ in a sand bath. The outlet containing desired product was placed in an Erlenmeyer flask. After removing solvent, desired product was collected as a brown powder (61\%) and stored at a temperature of $4{ }^{\circ} \mathrm{C}$.

1-adamantane isocyanate: ${ }^{1} \mathrm{H}$ NMR $(500 \mathrm{MHz}$, Chloroform- $d$ ) $\delta=7.59-7.52(\mathrm{~m}, 4 \mathrm{H}), 7.48(\mathrm{~s}, 4 \mathrm{H}), 3.92$ $(\mathrm{s}, 1 \mathrm{H}), 2.65(\mathrm{~s}, 7 \mathrm{H}), 2.33(\mathrm{q}, J=3.2,1 \mathrm{H}), 2.25(\mathrm{~d}, J=3.0,2 \mathrm{H}), 2.09-1.98(\mathrm{~m}, 2 \mathrm{H}) .{ }^{13} \mathrm{C}$ NMR $(126 \mathrm{MHz}$, Chloroform- $d$ ) $\delta=178.43,138.15,129.45,128.65,125.75,51.77,39.30,36.93,28.43,21.78$. HR-ESI-MS calcd. for $\mathrm{C}_{11} \mathrm{H}_{15} \mathrm{NO}[\mathrm{M}+\mathrm{MeOH}]^{+}: 209.31$, found 209.90 


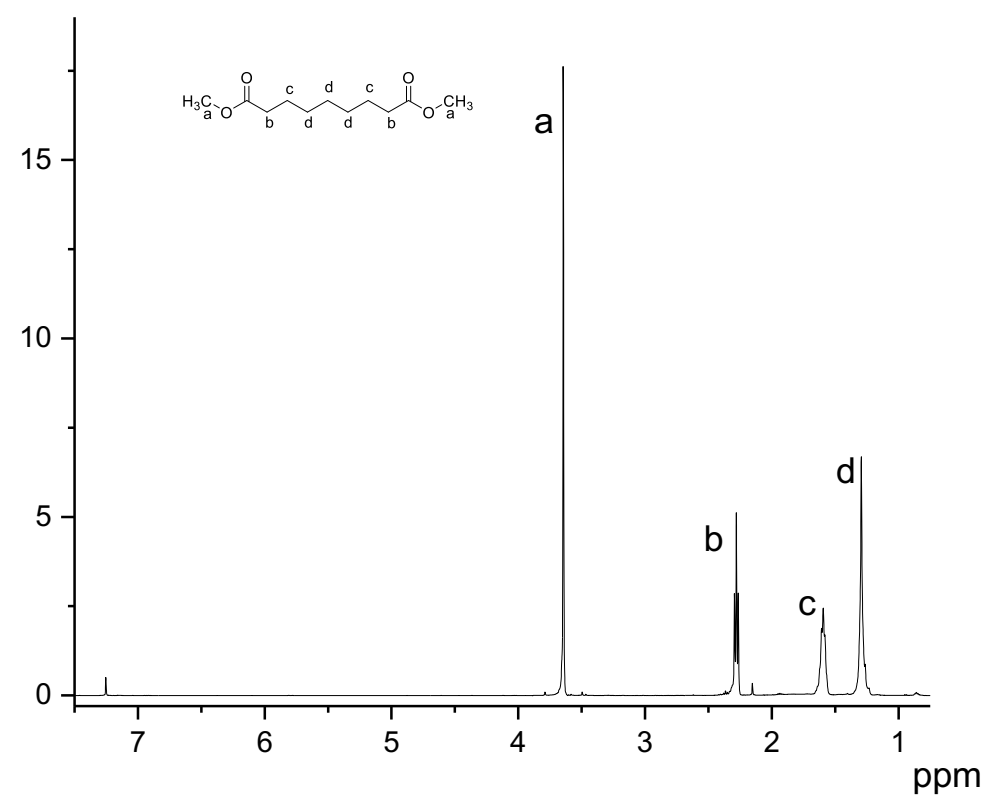

Figure S21: ${ }^{1} \mathrm{H}$ NMR of synthesized azelaic acid ester

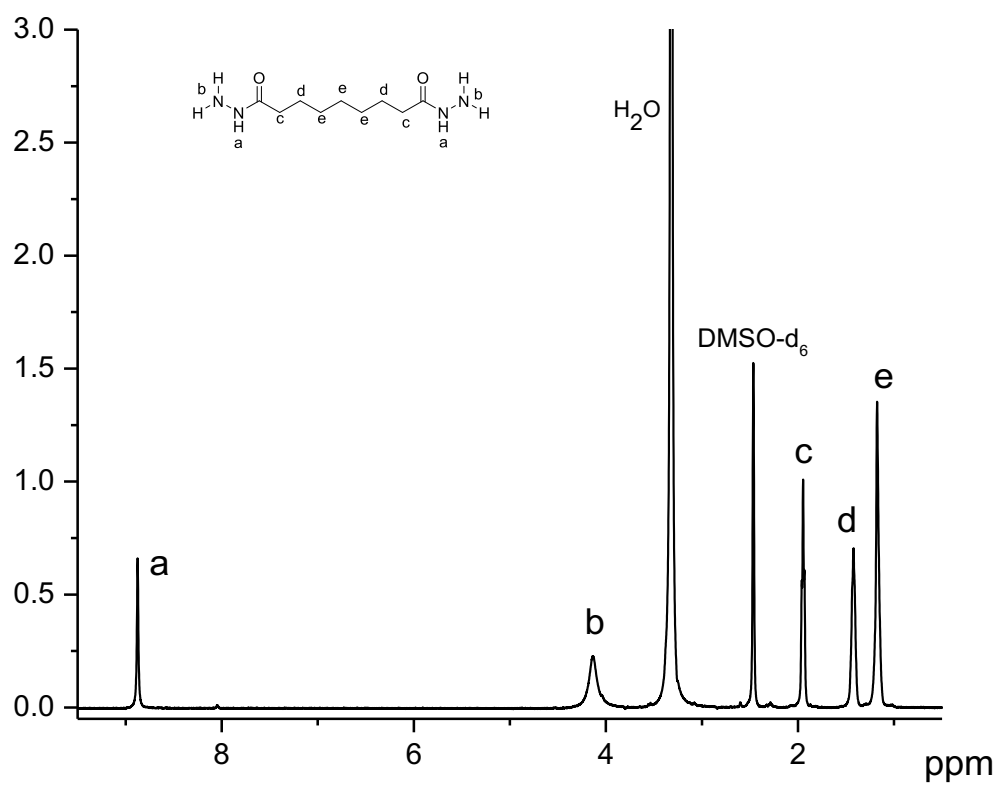

Figure S22: ${ }^{1} \mathrm{H}$ NMR of synthesized azelaic acid dihydrazide 


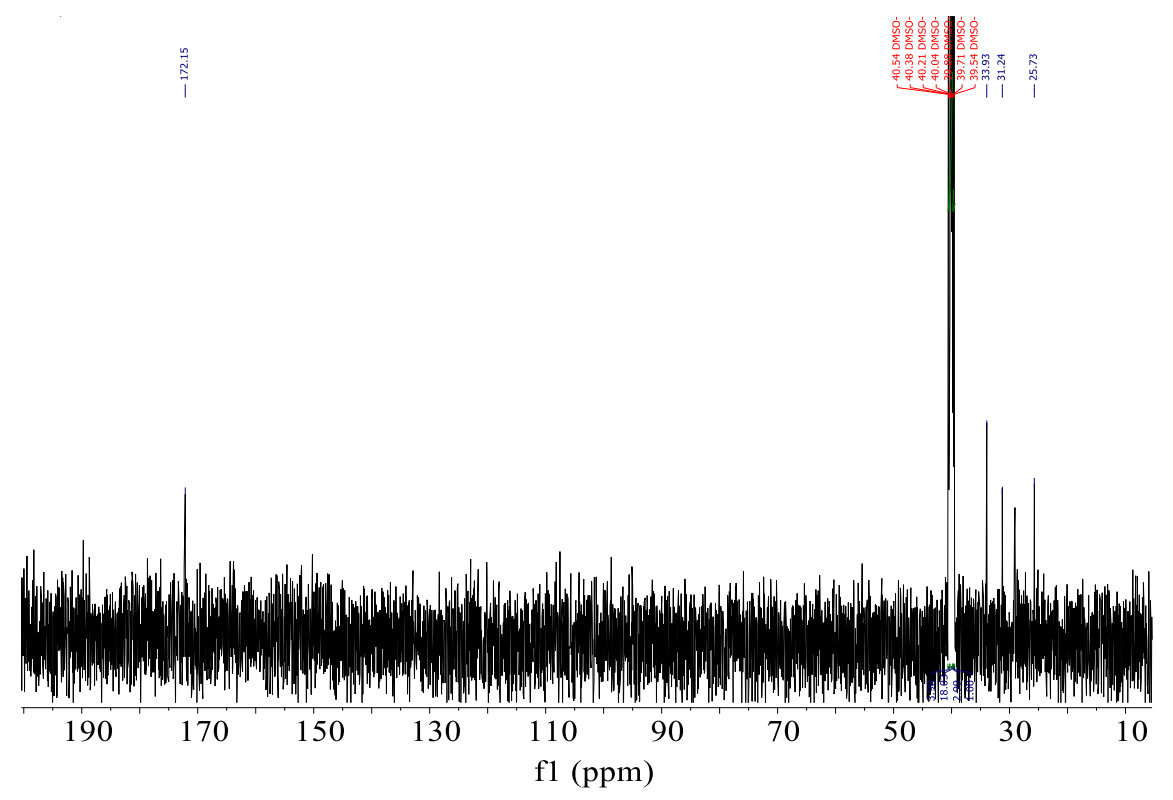

Figure S23: ${ }^{13} \mathrm{C}$ NMR of synthesized azelaic acid dihydrazide

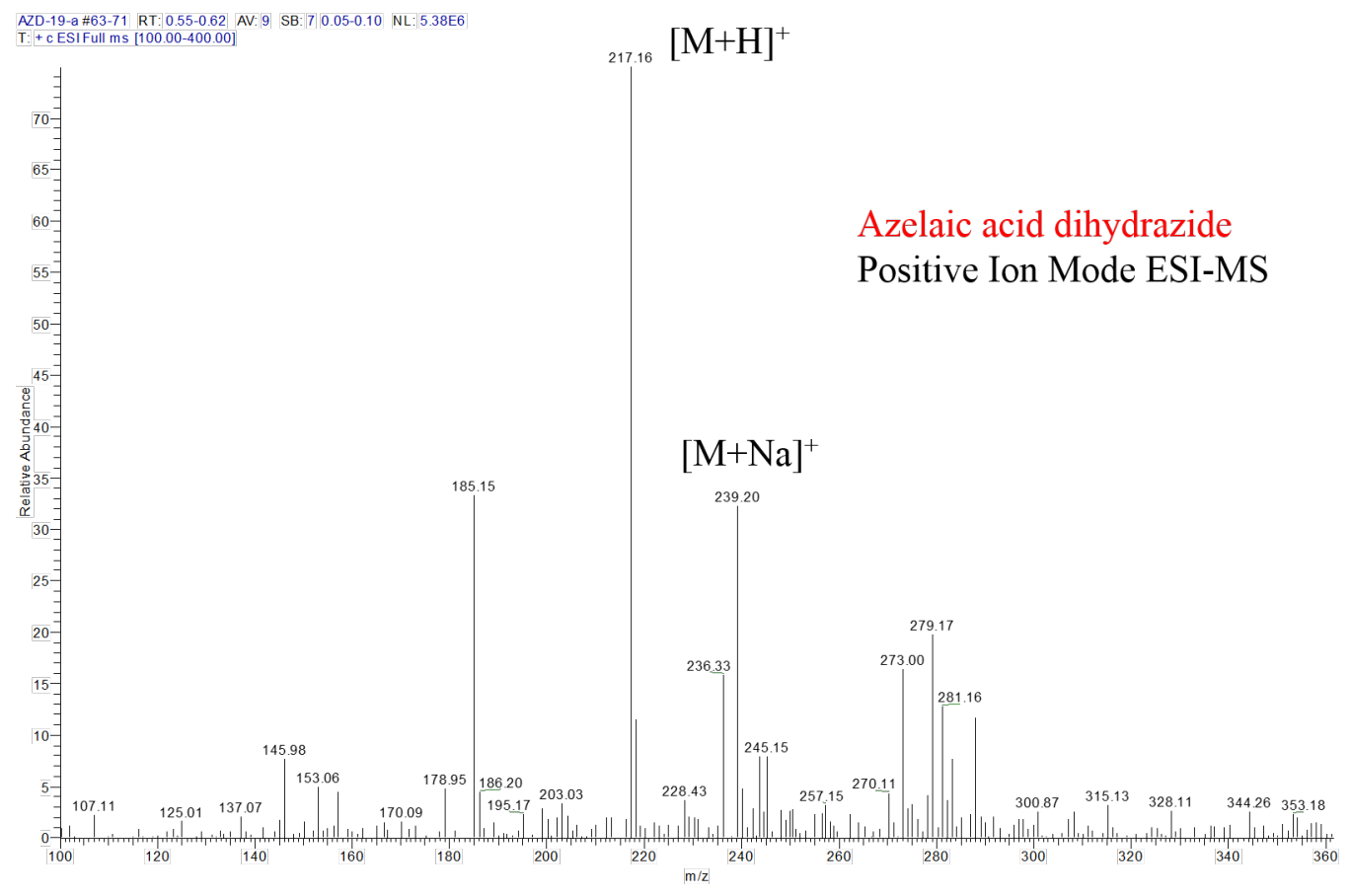

Figure S24: ESI-MS of synthesized Azelaic acid dihydrazide 


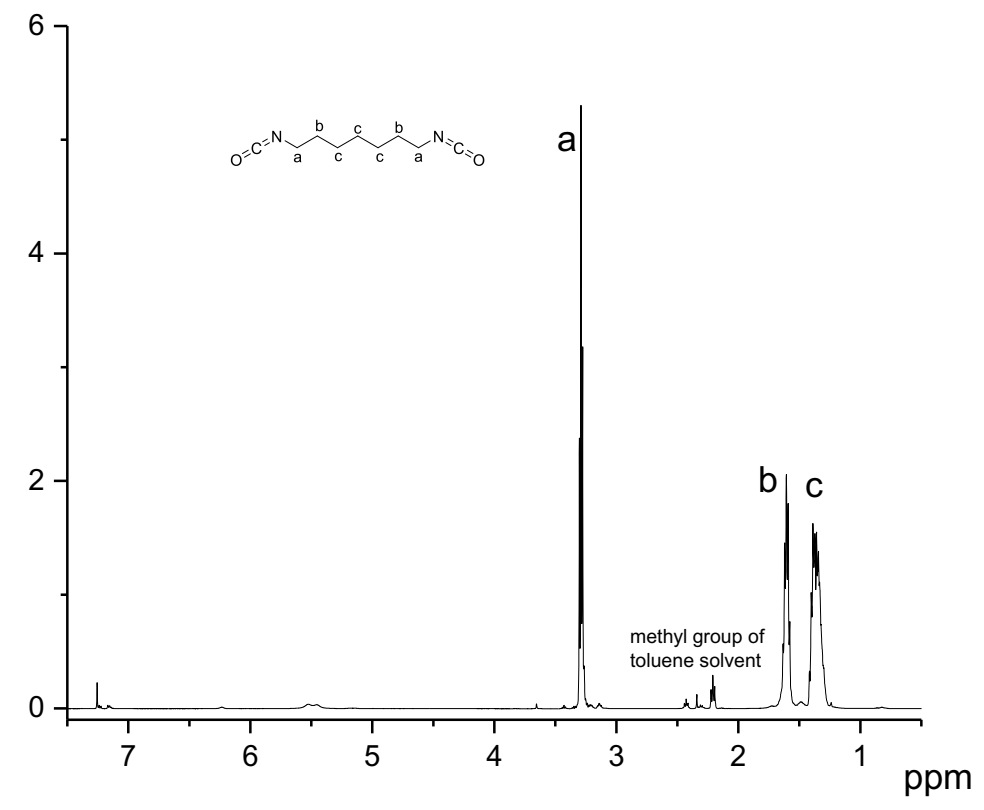

Figure S25: ${ }^{1} \mathrm{H}$ NMR of synthesized 1,7-heptamethylene diisocyanate

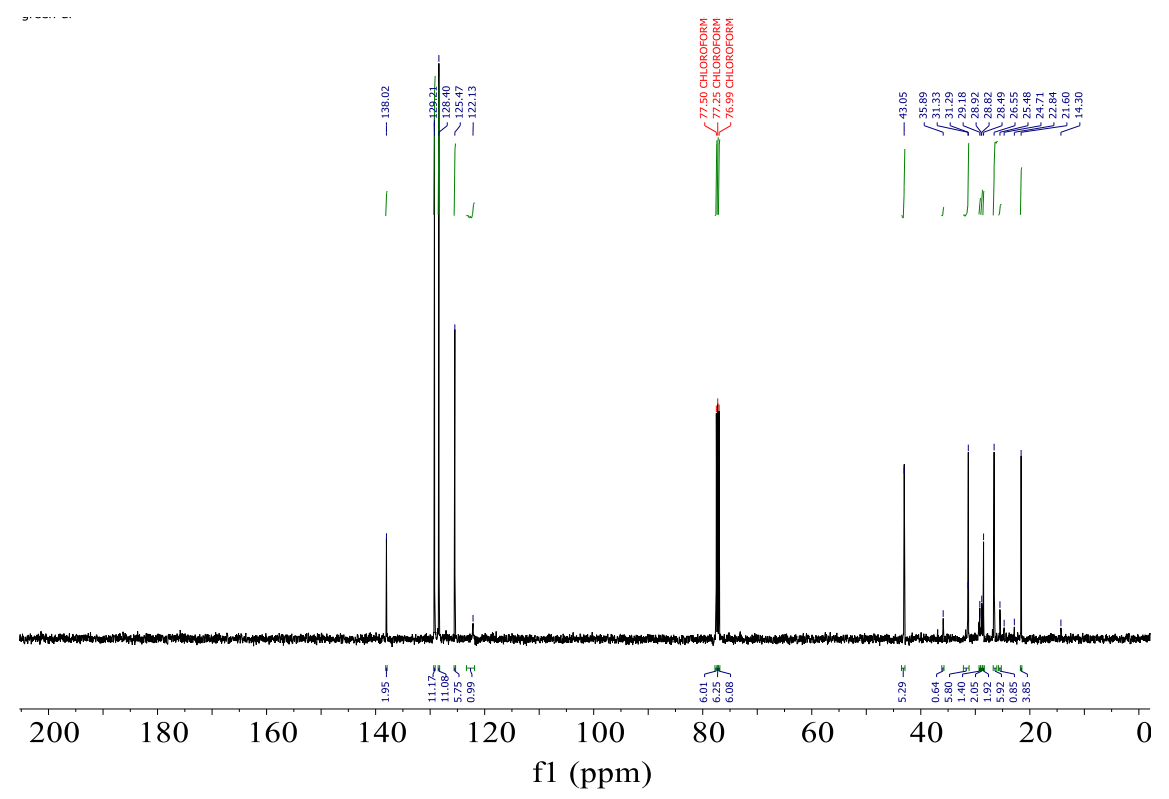

Figure S26: ${ }^{13} \mathrm{C}$ NMR of synthesized 1,7-heptamethylene diisocyanate 


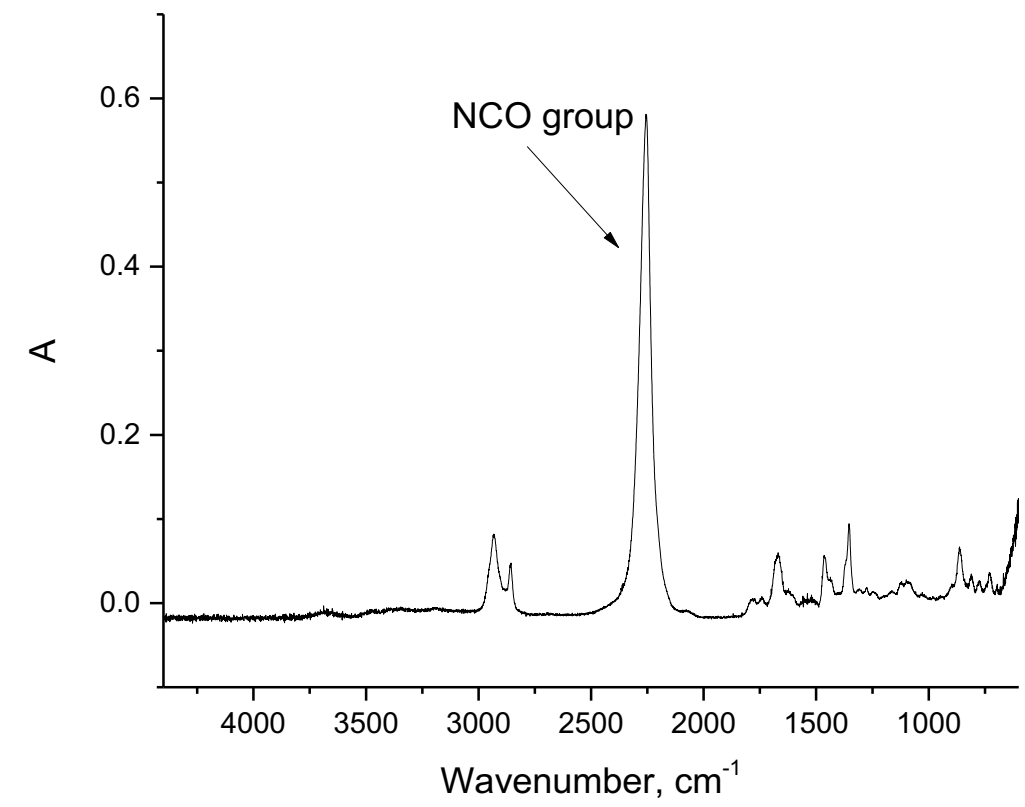

Figure S27: FT-IR of synthesized 1,7-heptamethylene diisocyanate

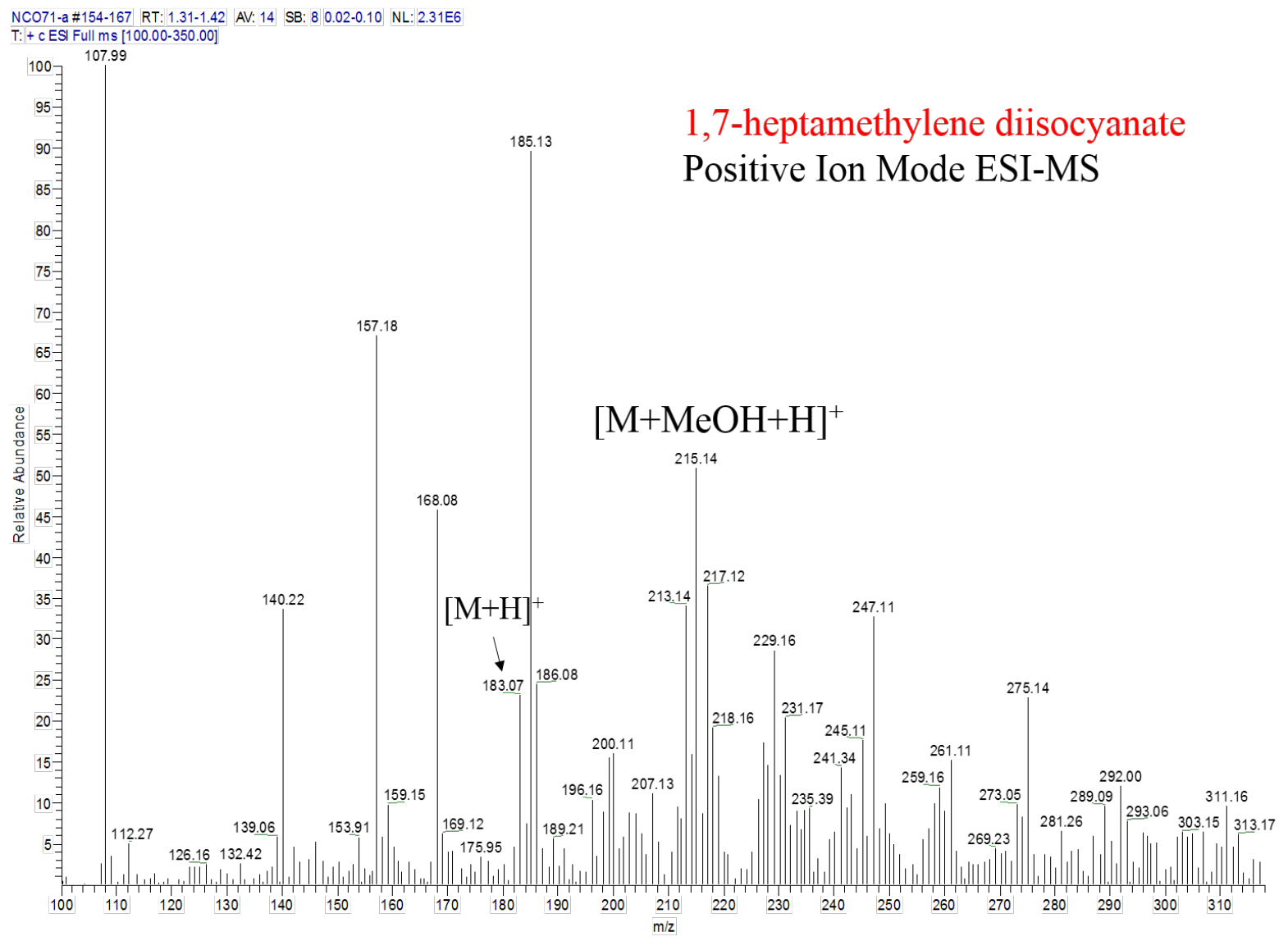

Figure S28: ESI-MS of synthesized 1,7-heptamethylene diisocyanate 


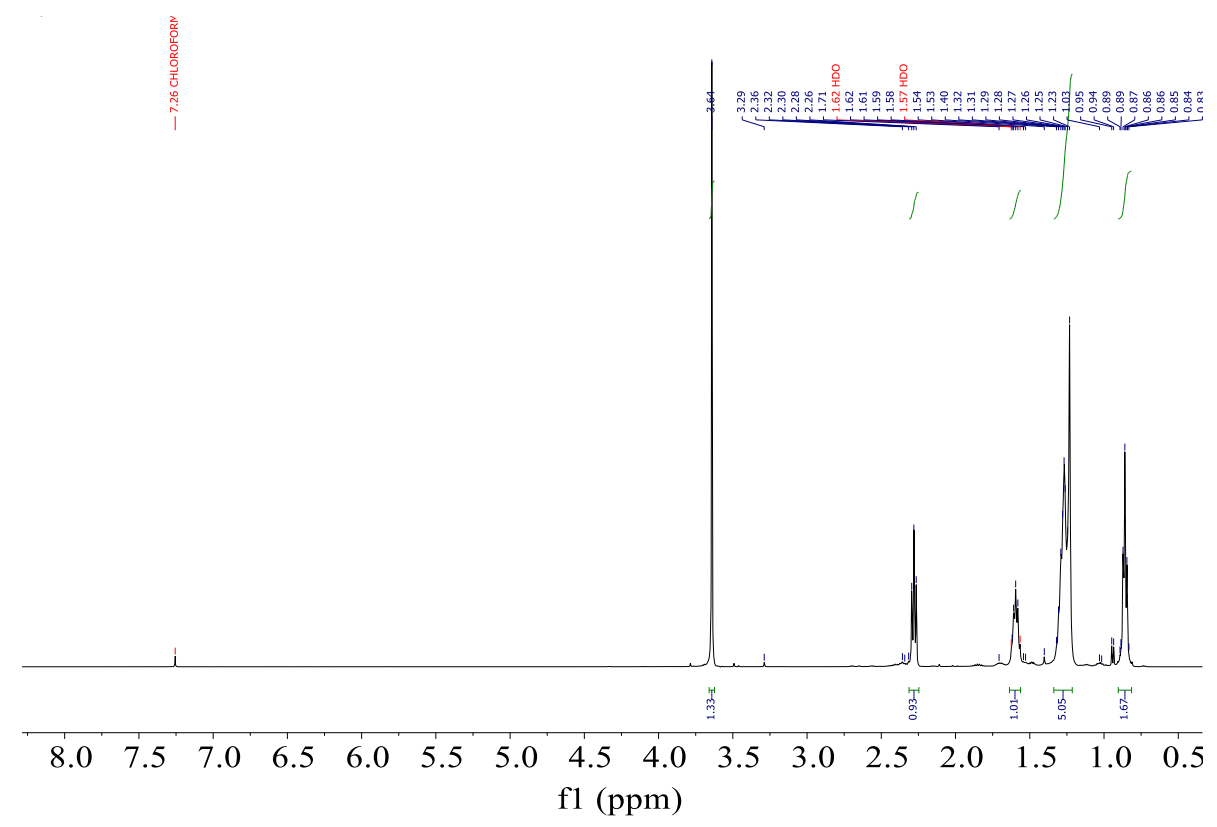

Figure S29: ${ }^{1} \mathrm{H}$ NMR of synthesized methyl heptanoate

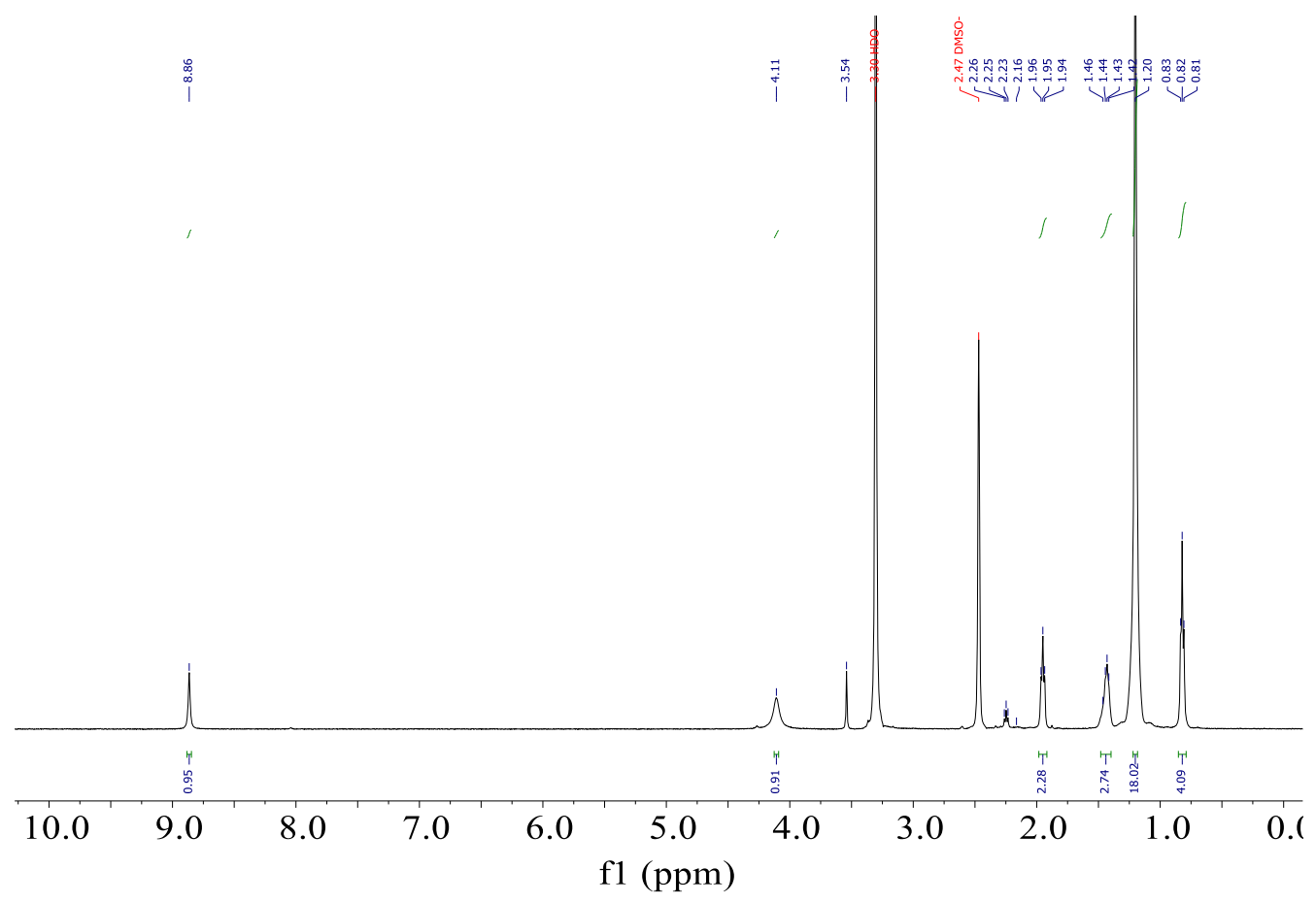

Figure S30: ${ }^{1} \mathrm{H}$ NMR of synthesized heptanoic acid hydrazide 


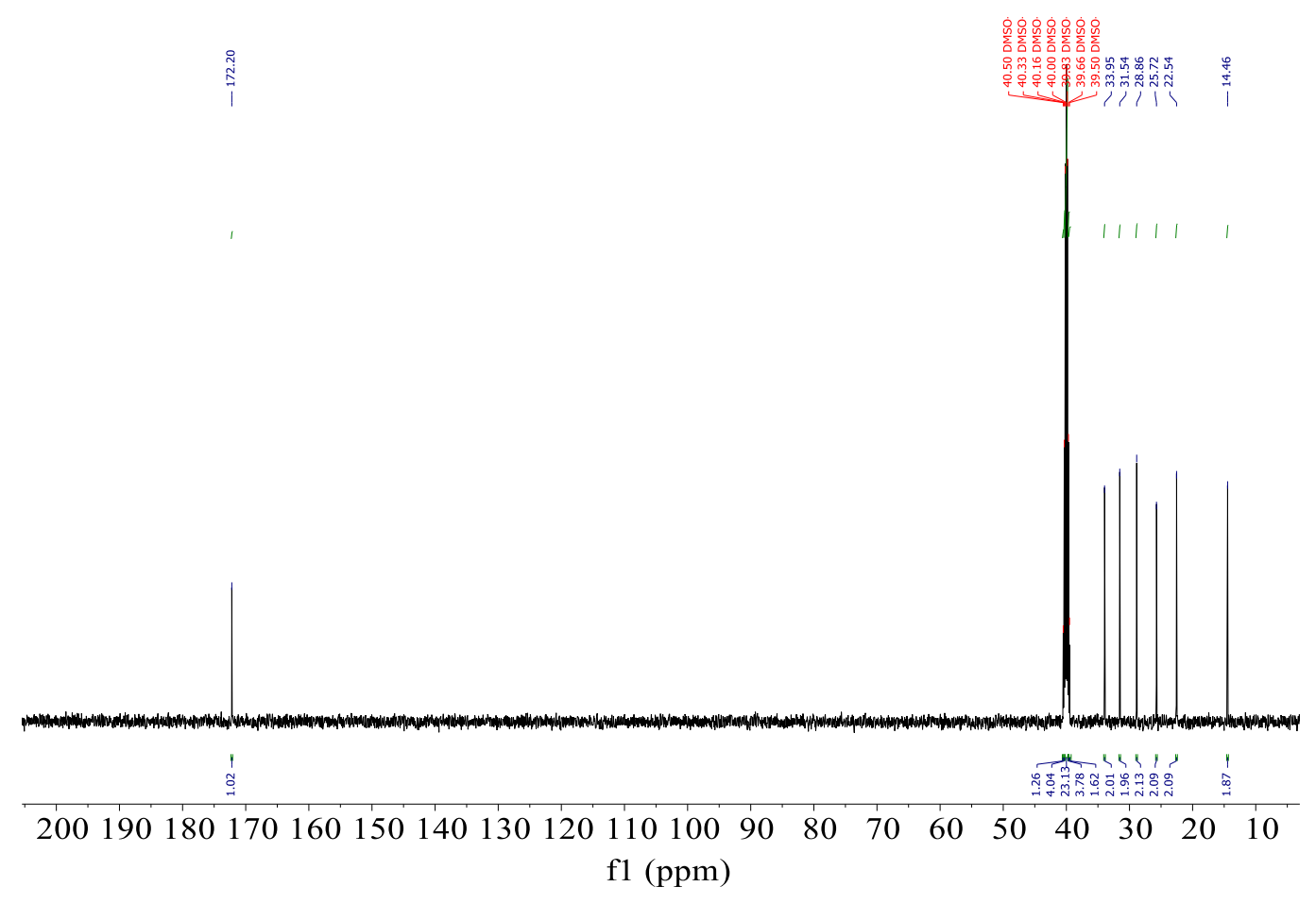

Figure S31: ${ }^{13} \mathrm{C}$ NMR of synthesized heptanoic acid hydrazide

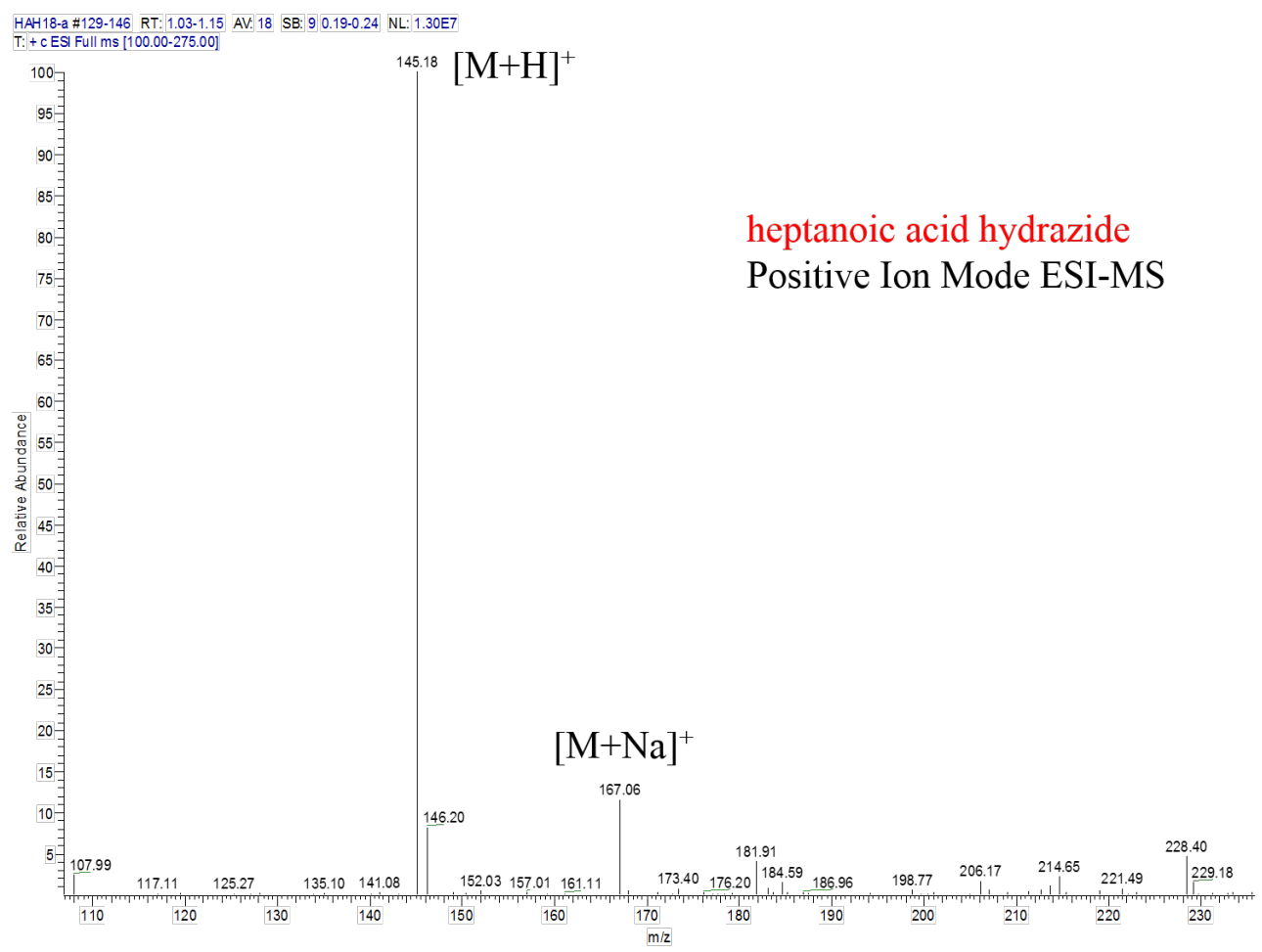

Figure S32: ESI MS of synthesized heptanoic acid hydrazide 


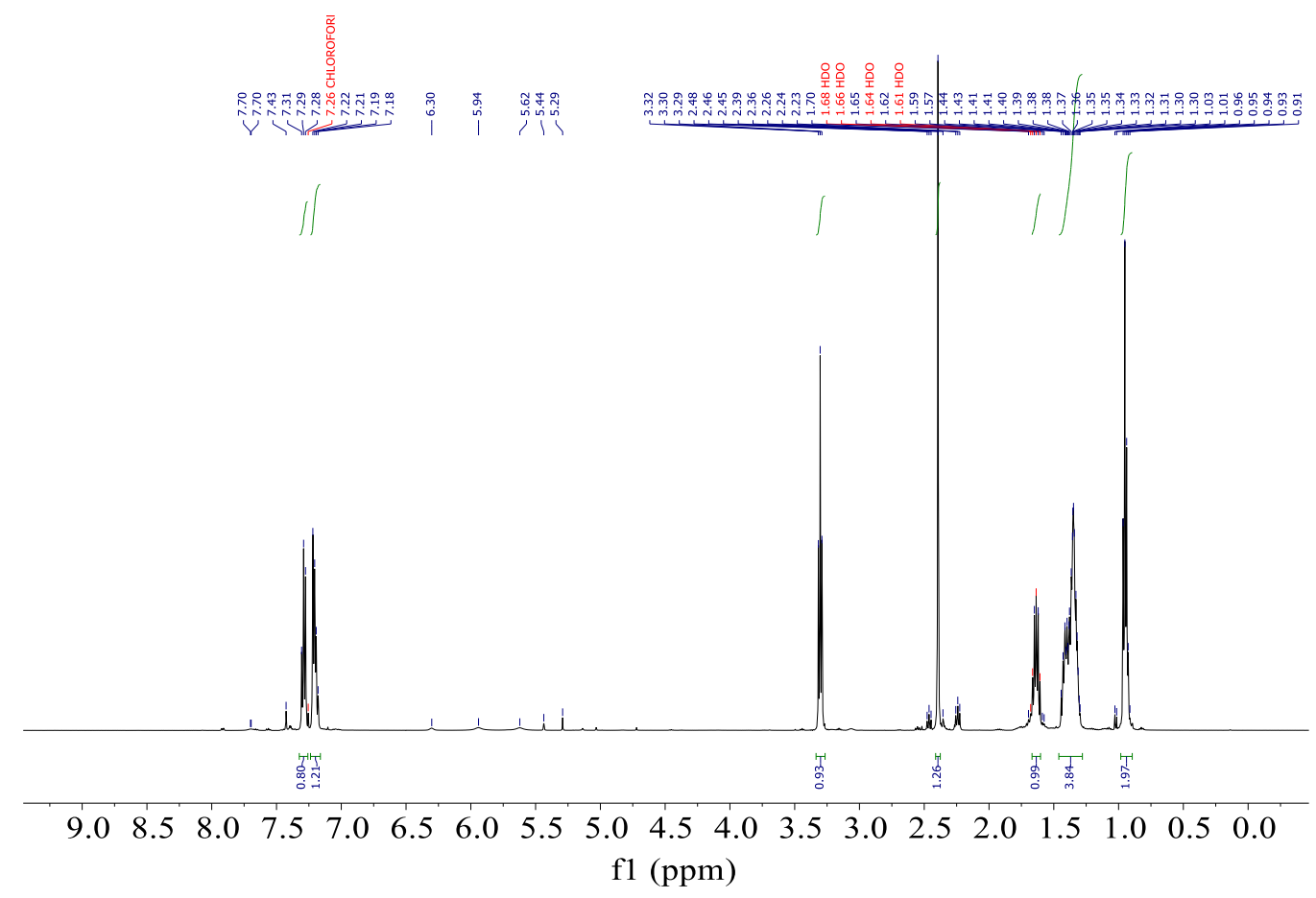

Figure S33: ${ }^{1} \mathrm{H}$ NMR of synthesized hexyl isocyanate

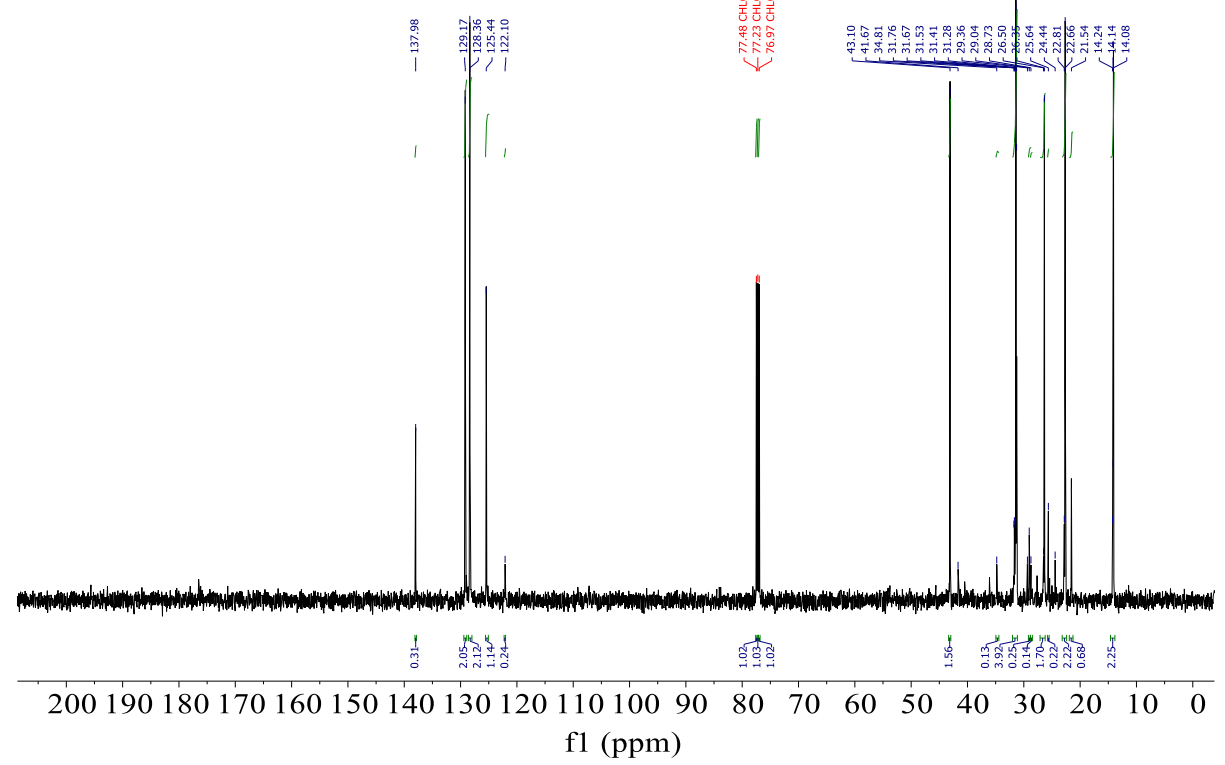

Figure S34: ${ }^{13} \mathrm{C}$ NMR of synthesized hexyl isocyanate 


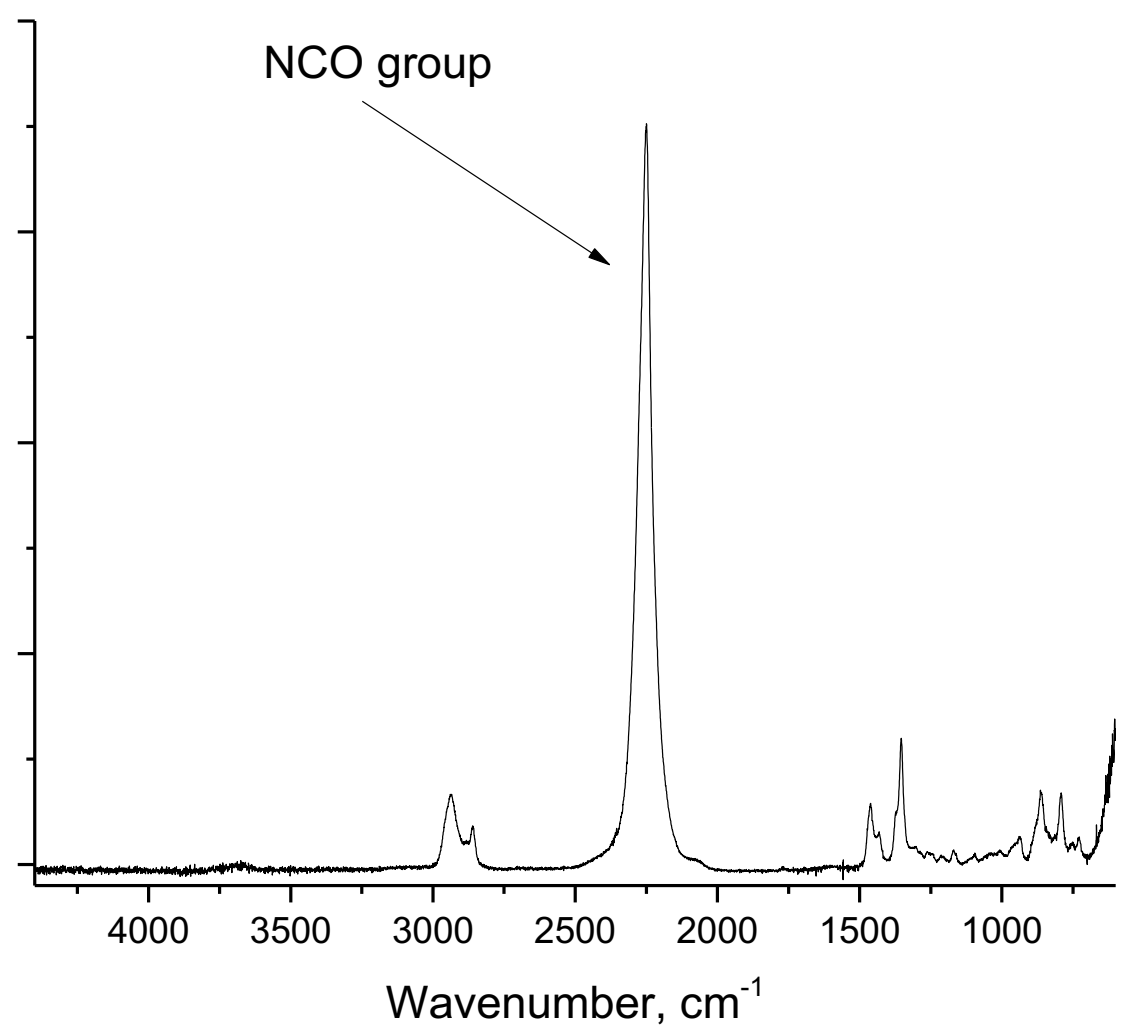

Figure S35: FT-IR of synthesized hexyl isocyanate

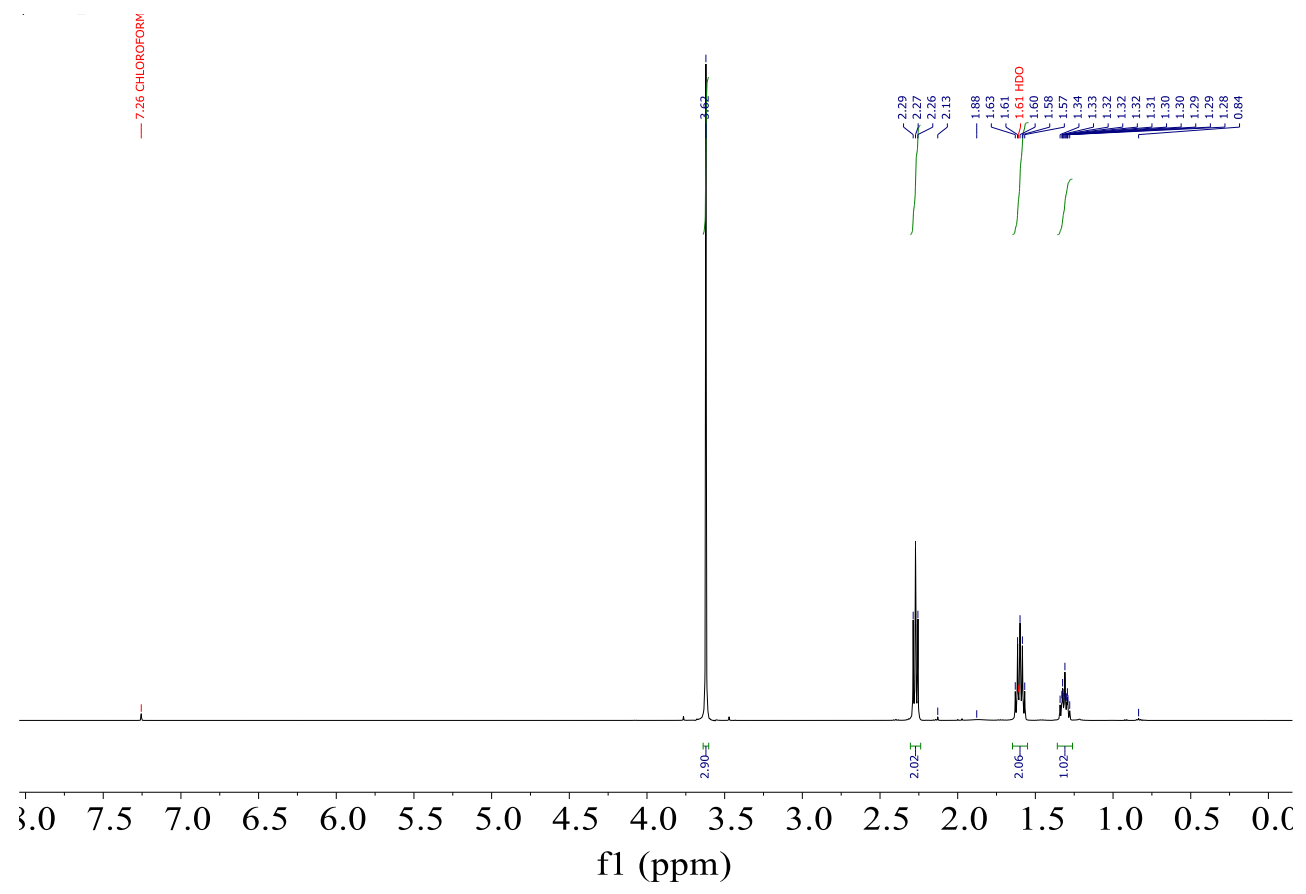

Figure S36: ${ }^{1} \mathrm{H}$ NMR of synthesized pimelic acid ester 


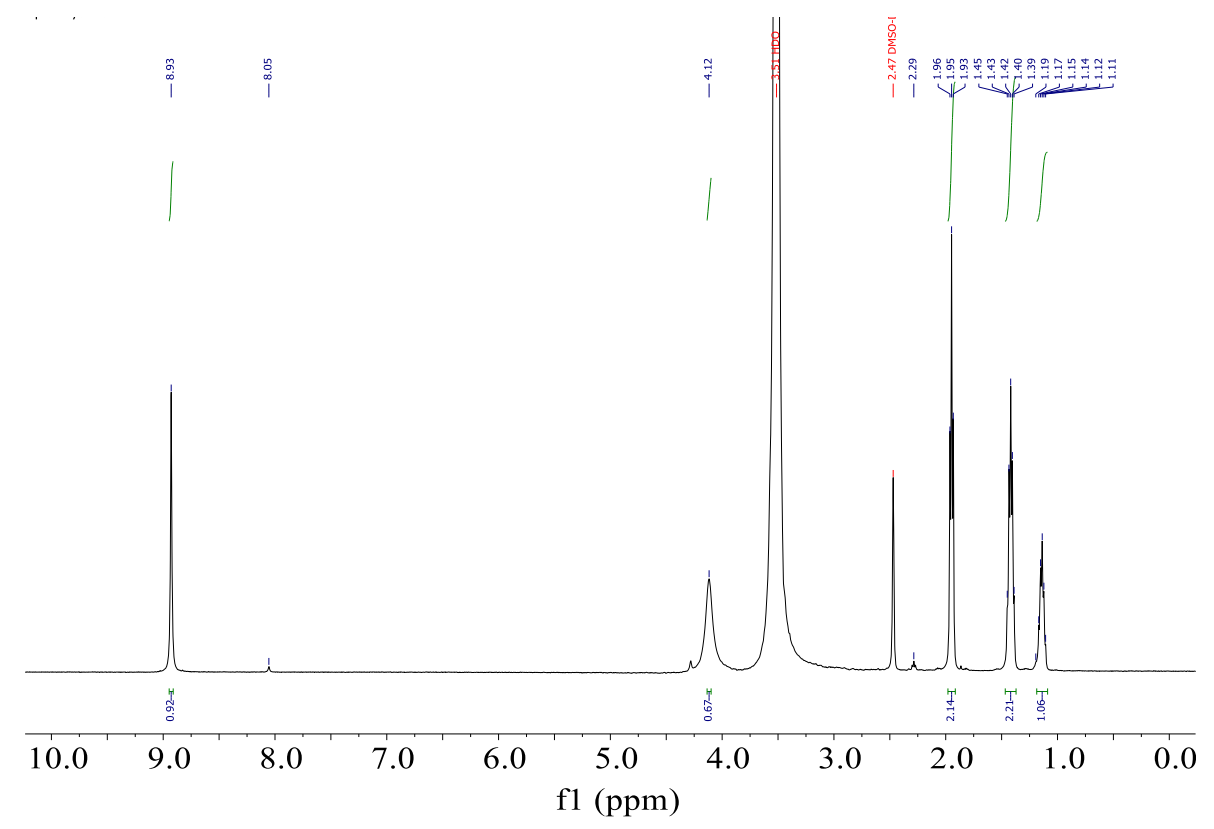

Figure S37: ${ }^{1} \mathrm{H}$ NMR of synthesized pimelic acid dihydrazide

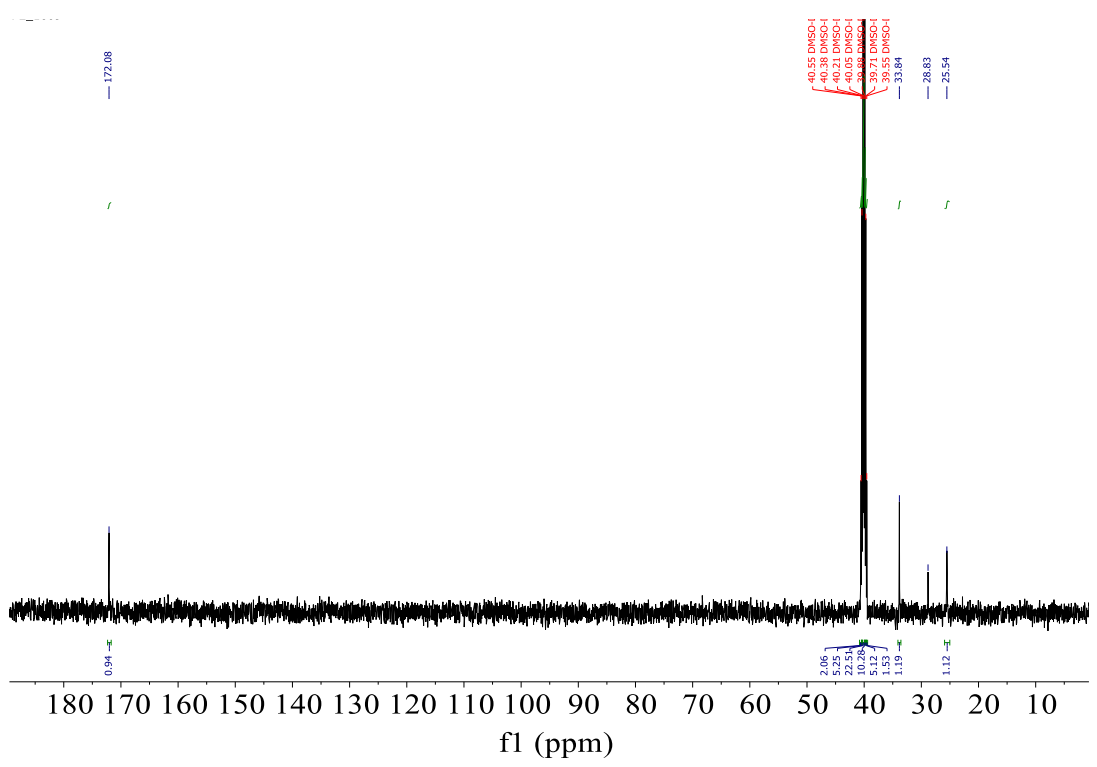

Figure S38: ${ }^{13} \mathrm{C}$ NMR of synthesized pimelic acid dihydrazide 


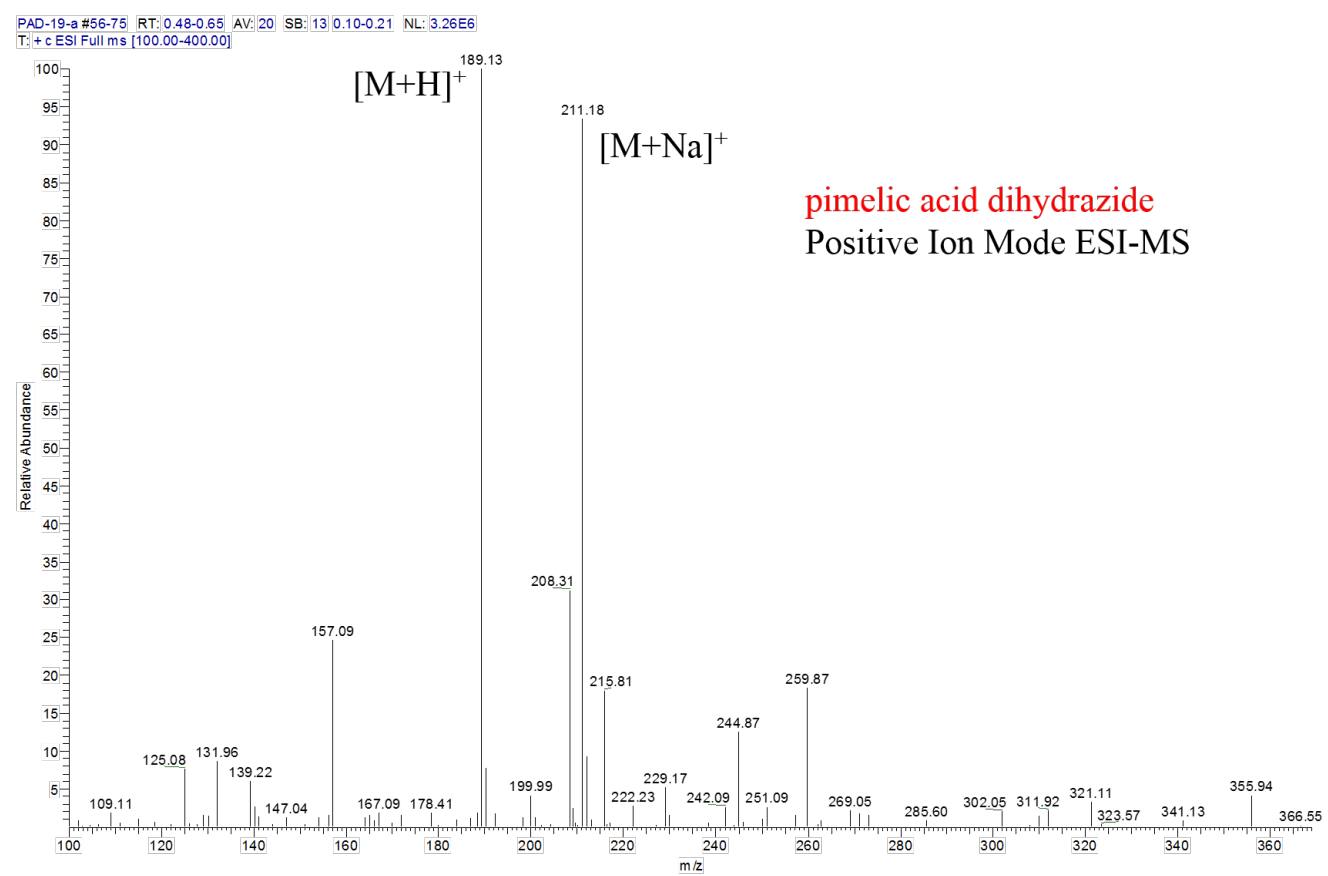

Figure S39: ESI MS of synthesized pimelic acid dihydrazide

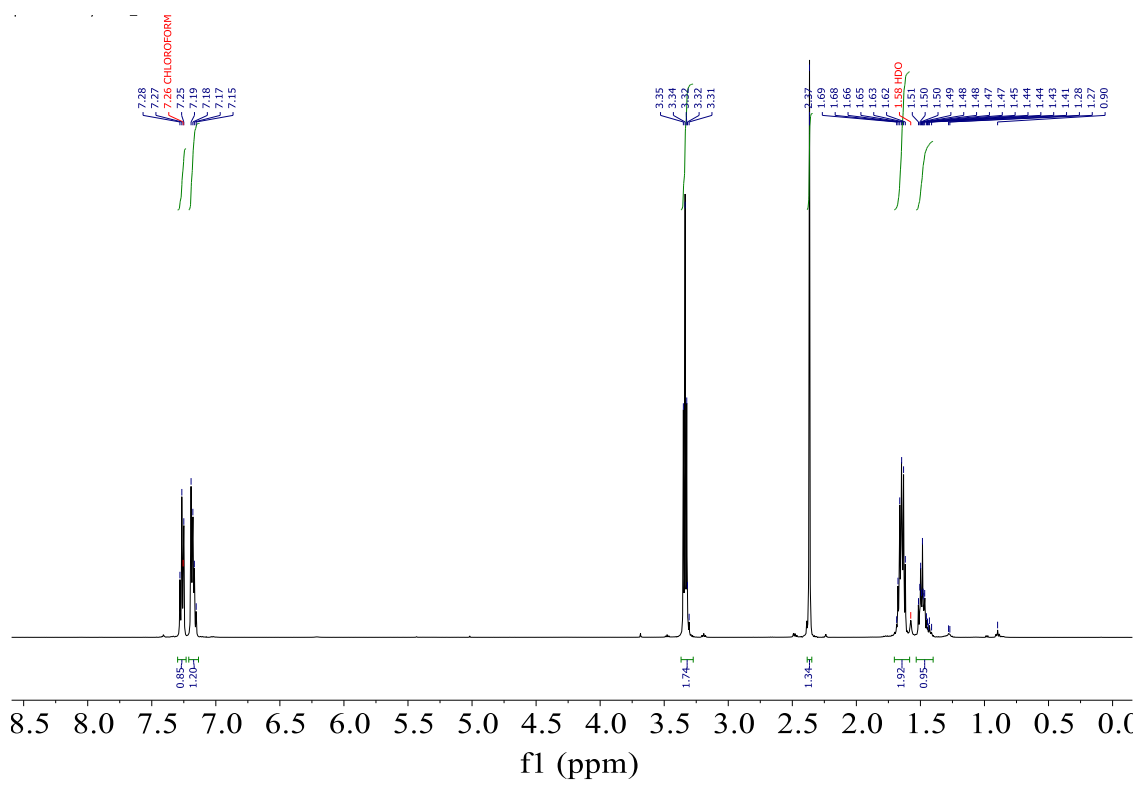

Figure S40: ${ }^{1} \mathrm{H}$ NMR of synthesized tetramethylene diisocyanate 


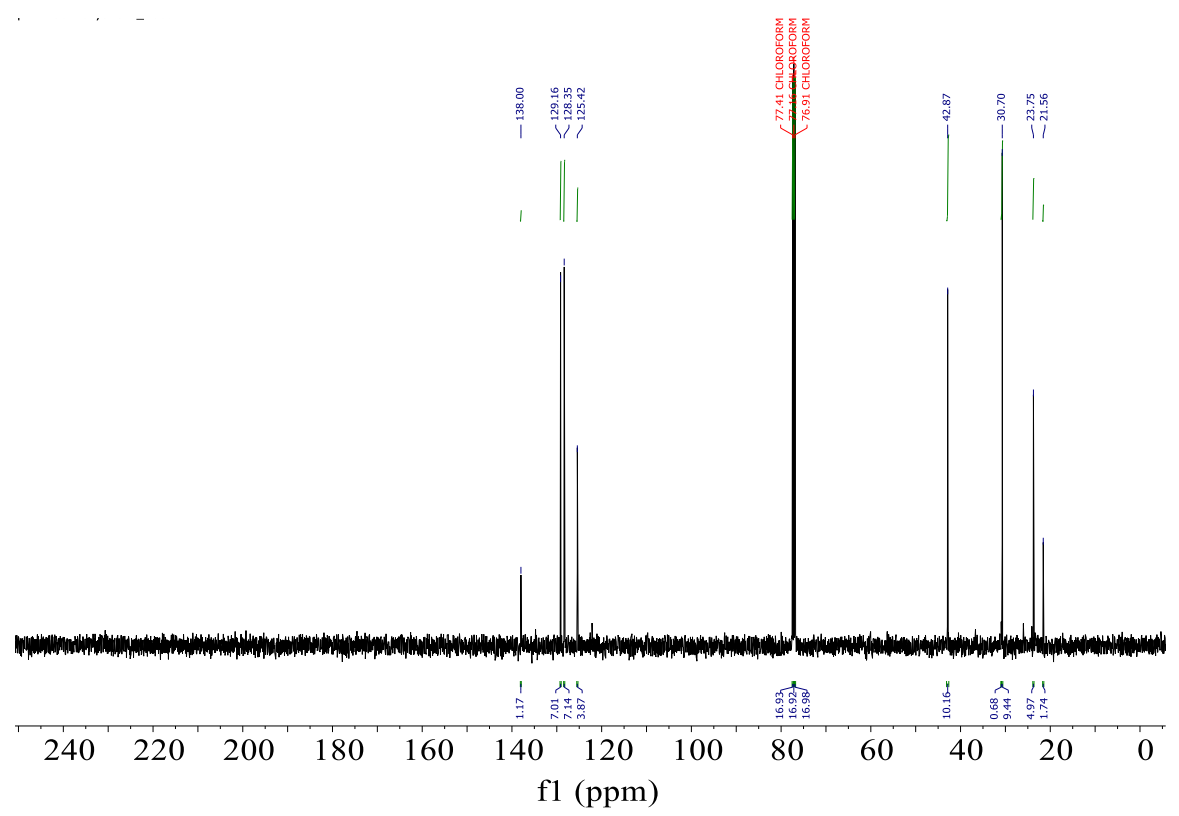

Figure S41: ${ }^{13} \mathrm{C}$ NMR of synthesized tetramethylene diisocyanate

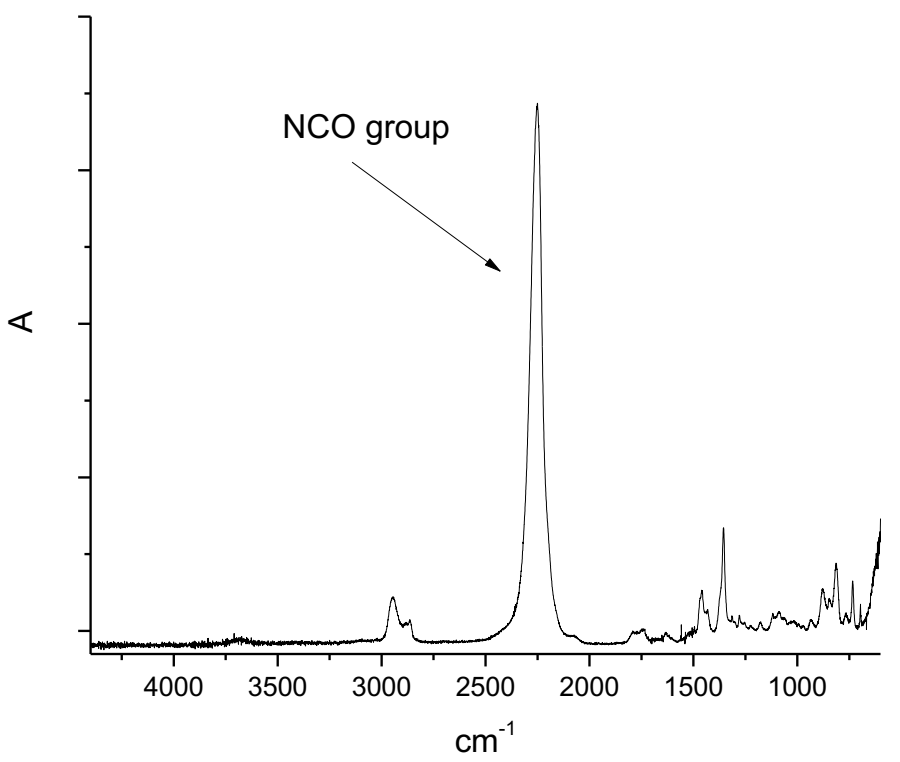

Figure S42: FT-IR of synthesized tetramethylene diisocyanate 


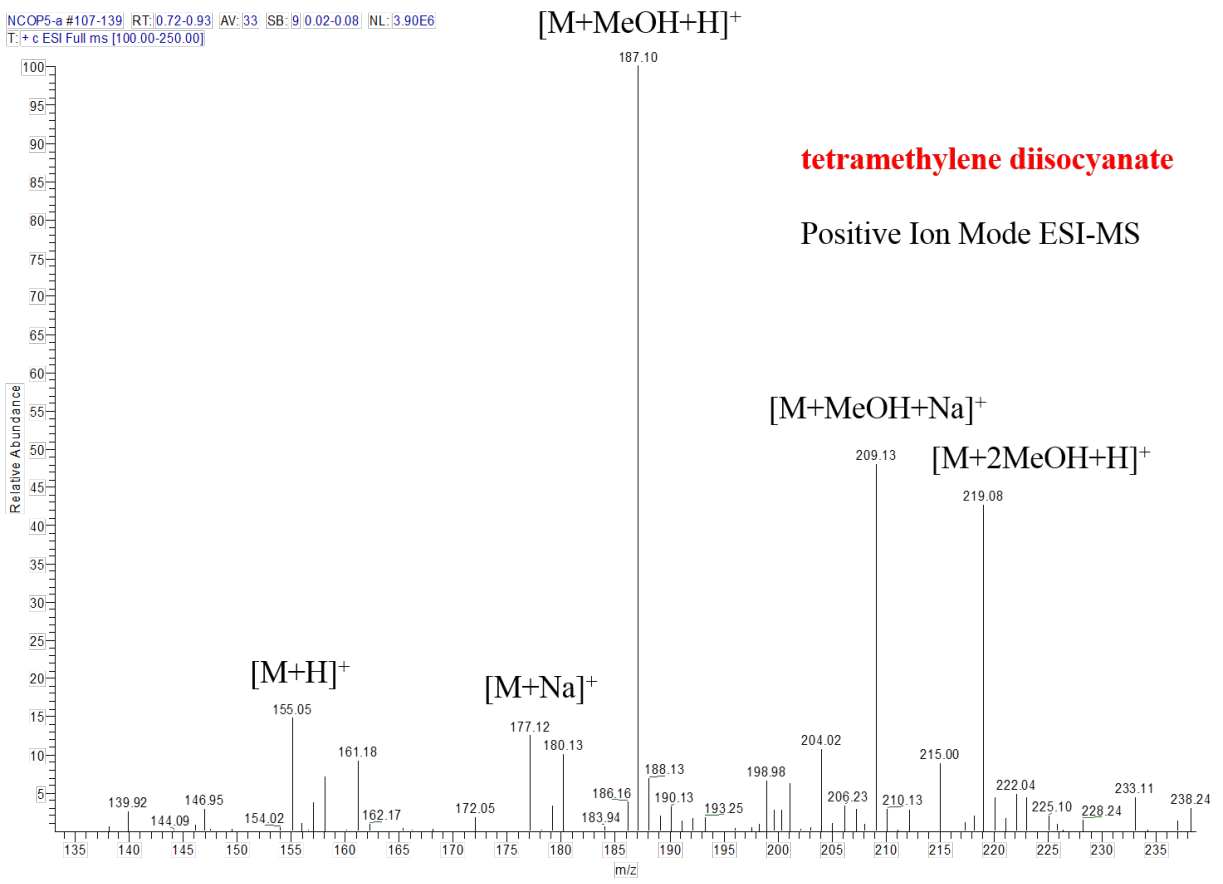

Figure S43: ESI MS of synthesized tetramethylene diisocyanate

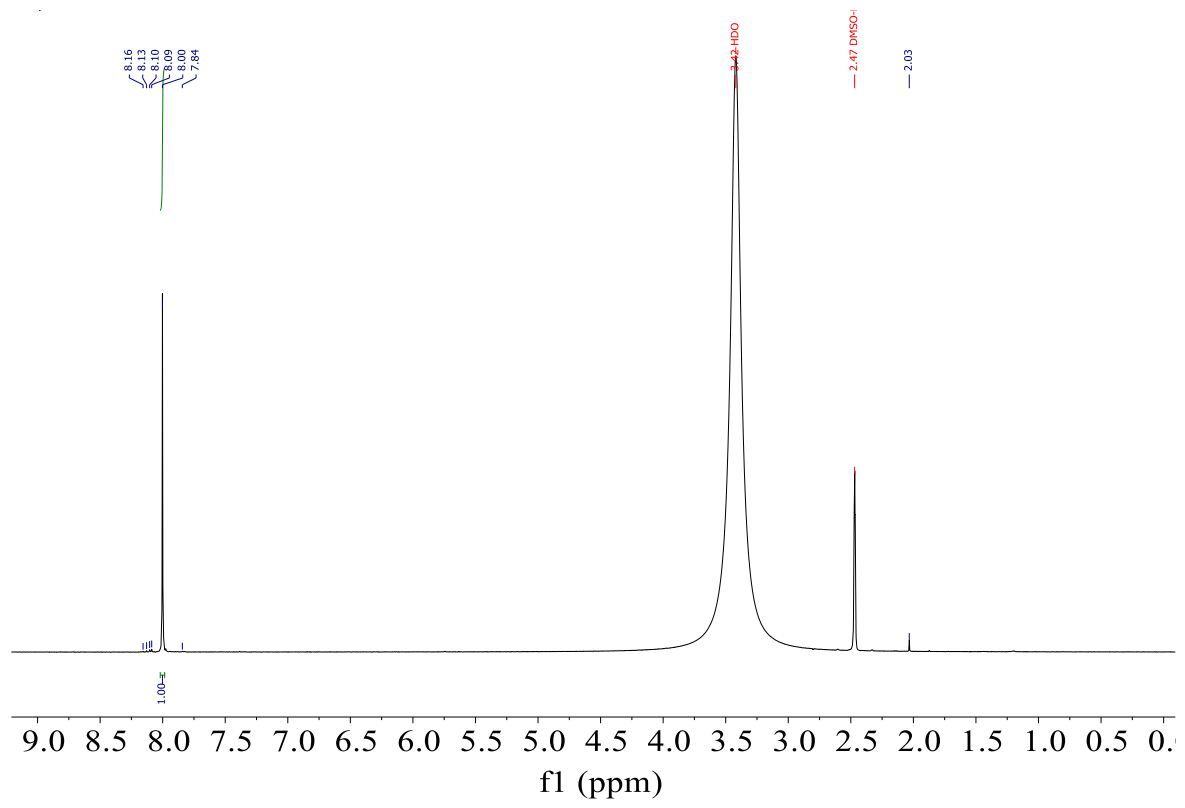

Figure S44: ${ }^{1} \mathrm{H}$ NMR of synthesized terephthalic acid 


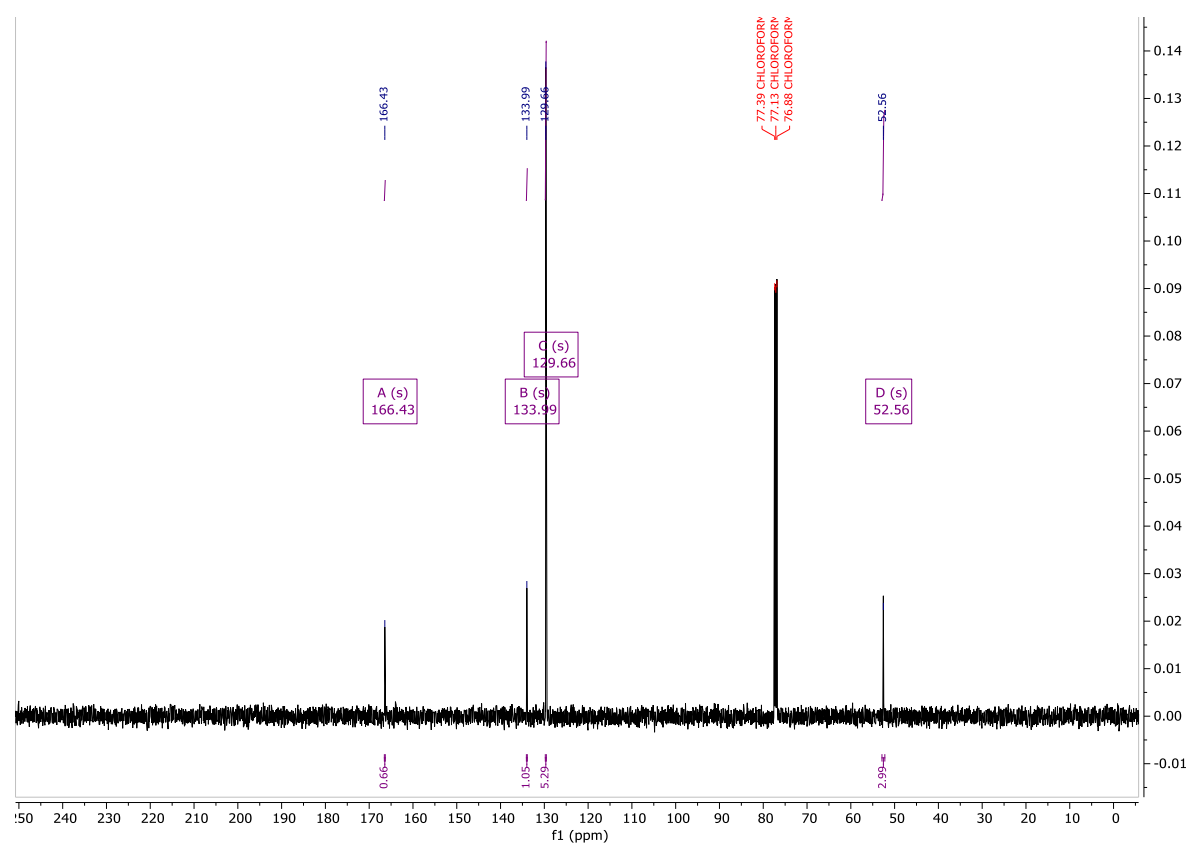

Figure $\mathrm{S} 45:{ }^{1} \mathrm{H} \&{ }^{13} \mathrm{C}$ NMR of synthesized dimethylterephthalate

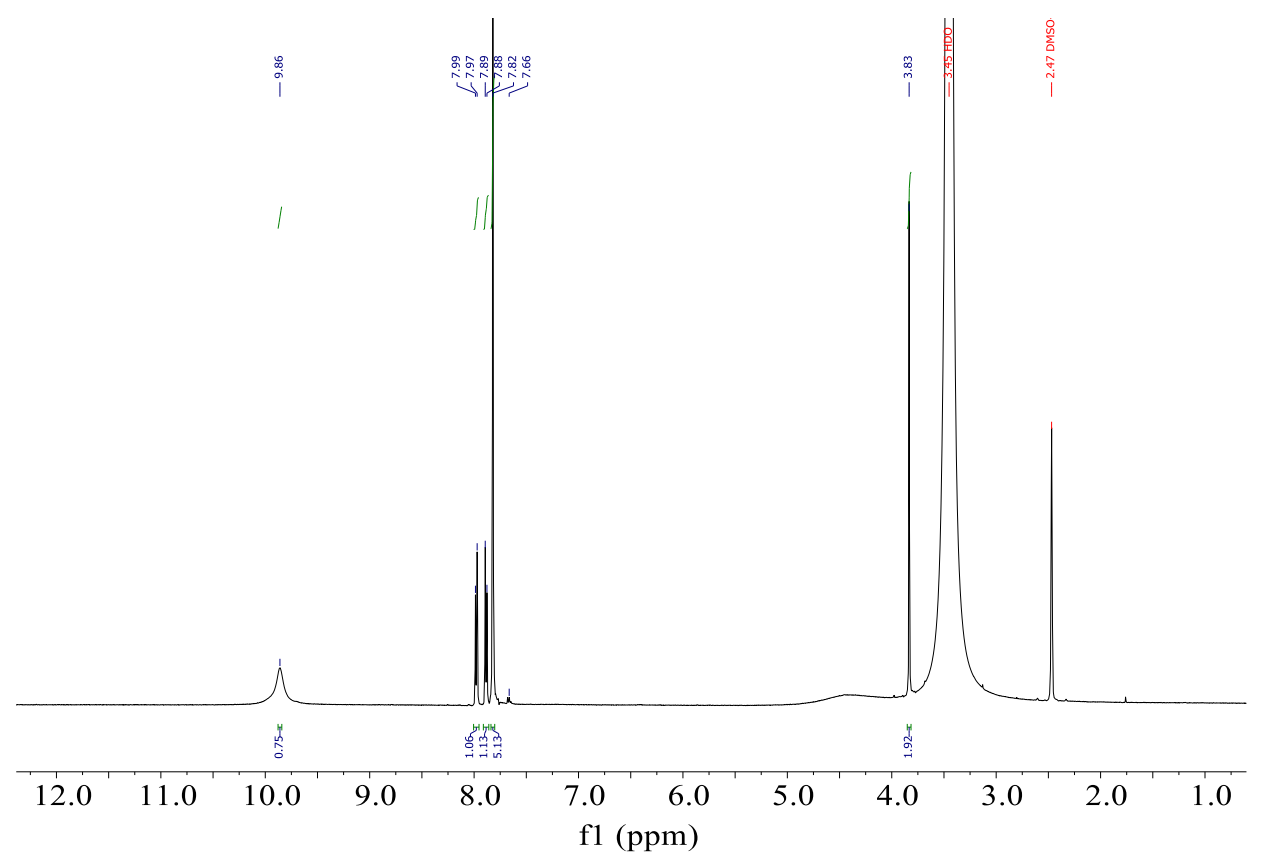

Figure S46: ${ }^{1} \mathrm{H}$ NMR of synthesized terephthalic acid dihydrazide 


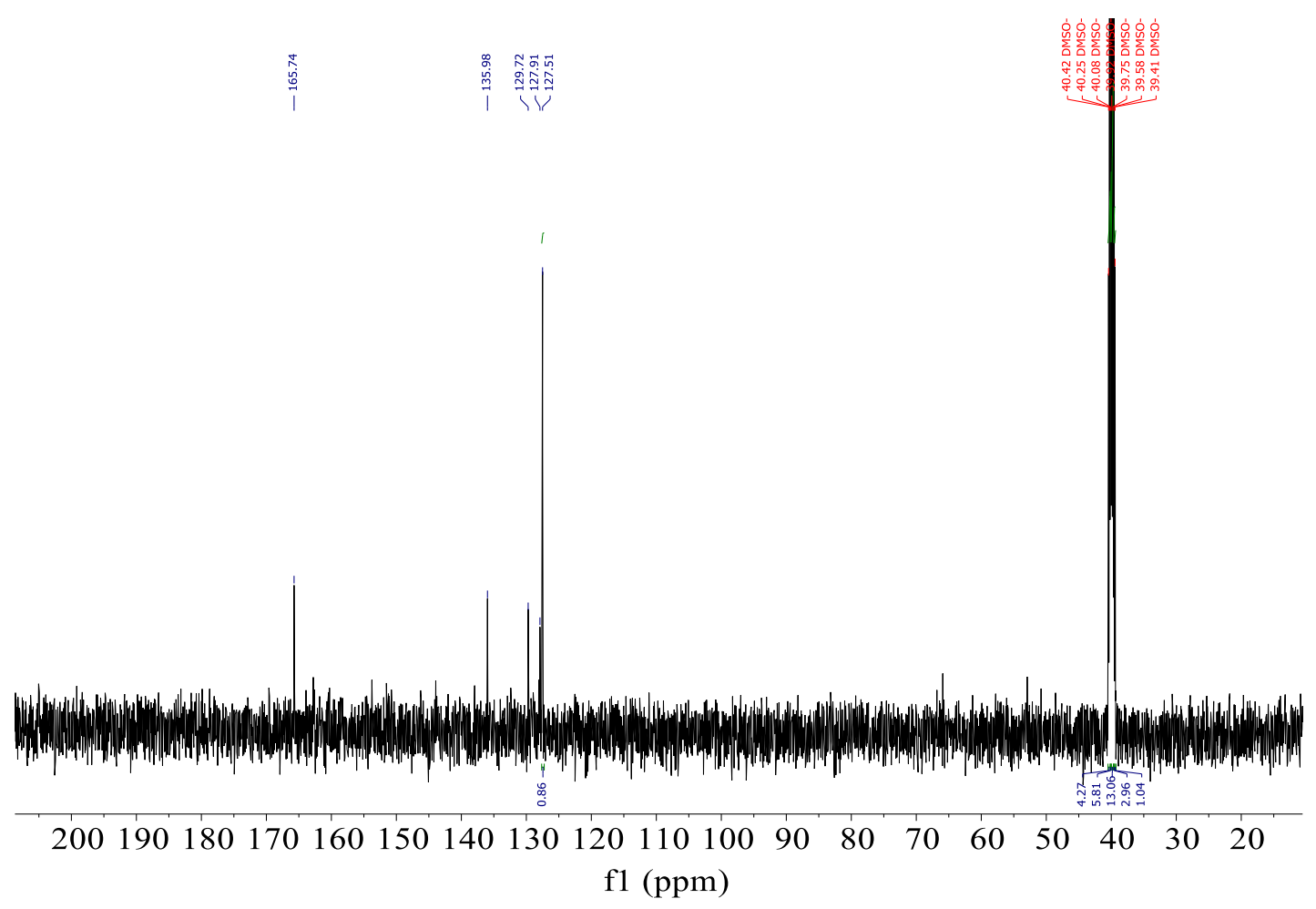

Figure S47: ${ }^{13} \mathrm{C}$ NMR of synthesized terephthalic acid dihydrazide

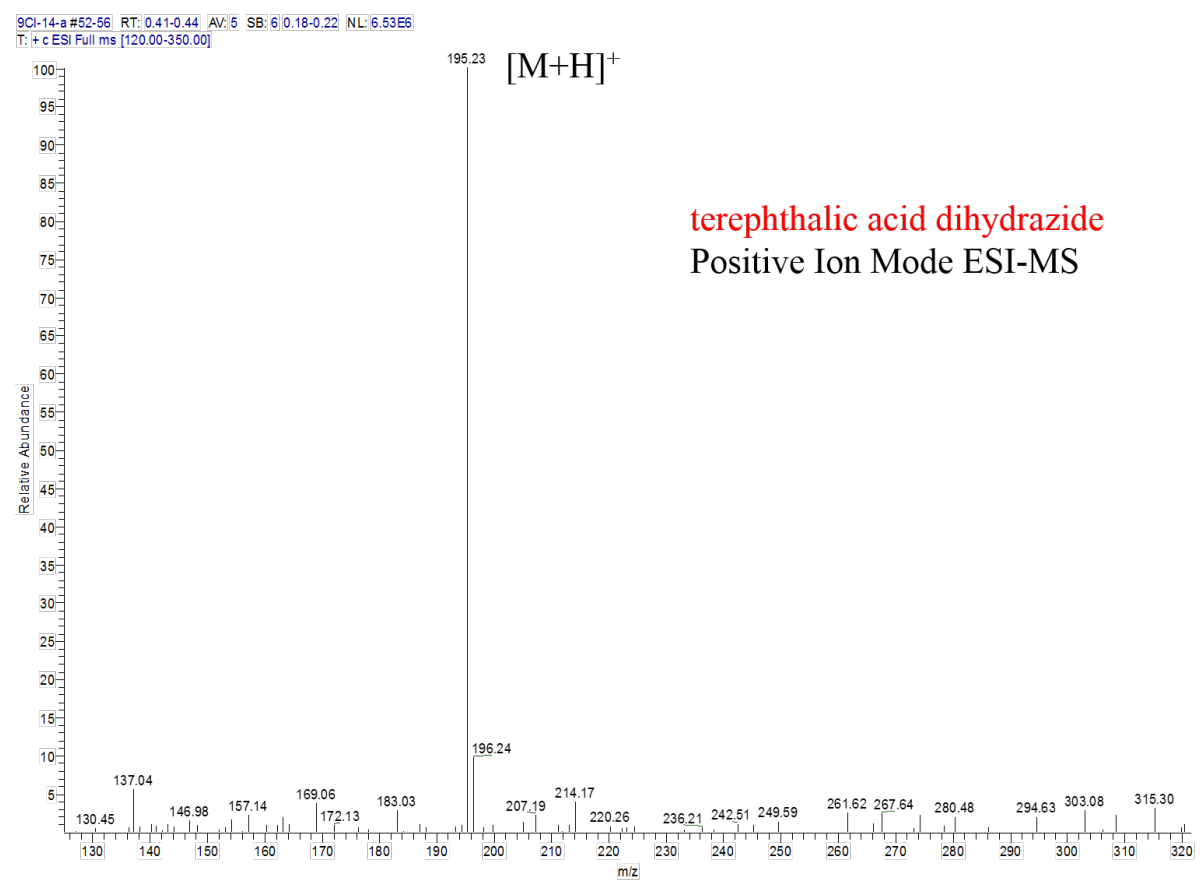

Figure S48: ESI MS of synthesized terephthalic acid dihydrazide 


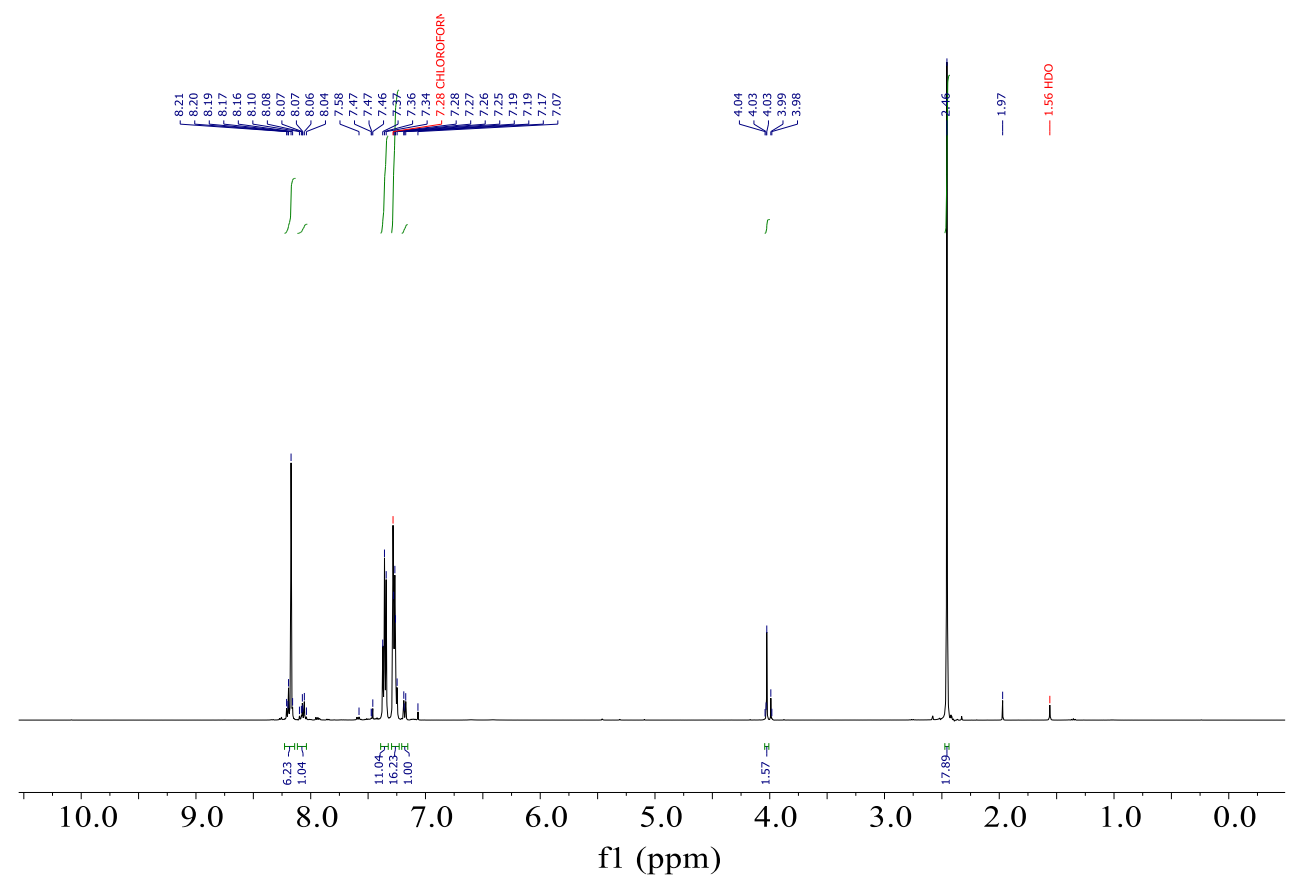

Figure S49: ${ }^{1} \mathrm{H}$ NMR of synthesized 1,4-phenylene diisocyanate

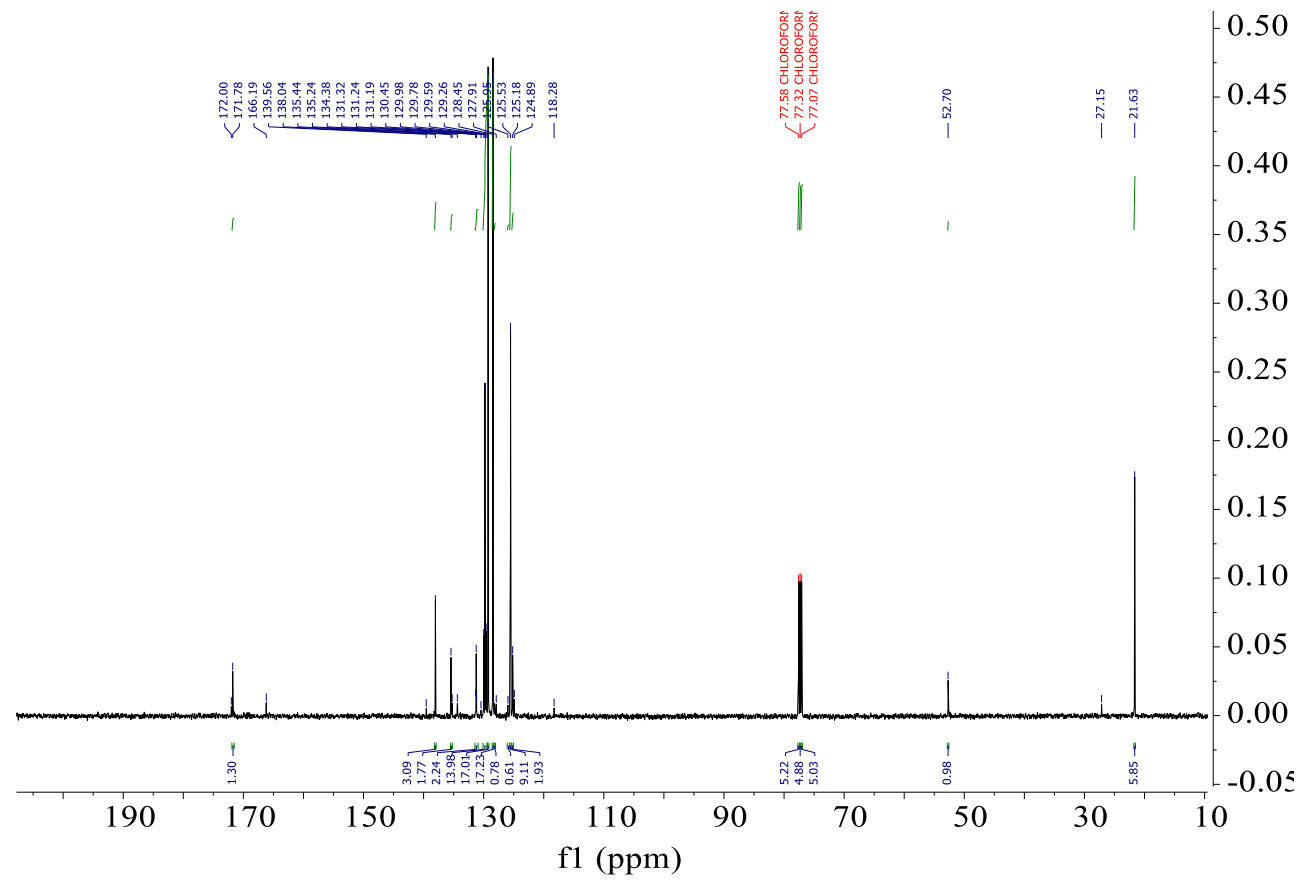

Figure S50: ${ }^{13} \mathrm{C}$ NMR of synthesized 1,4-phenylene diisocyanate 


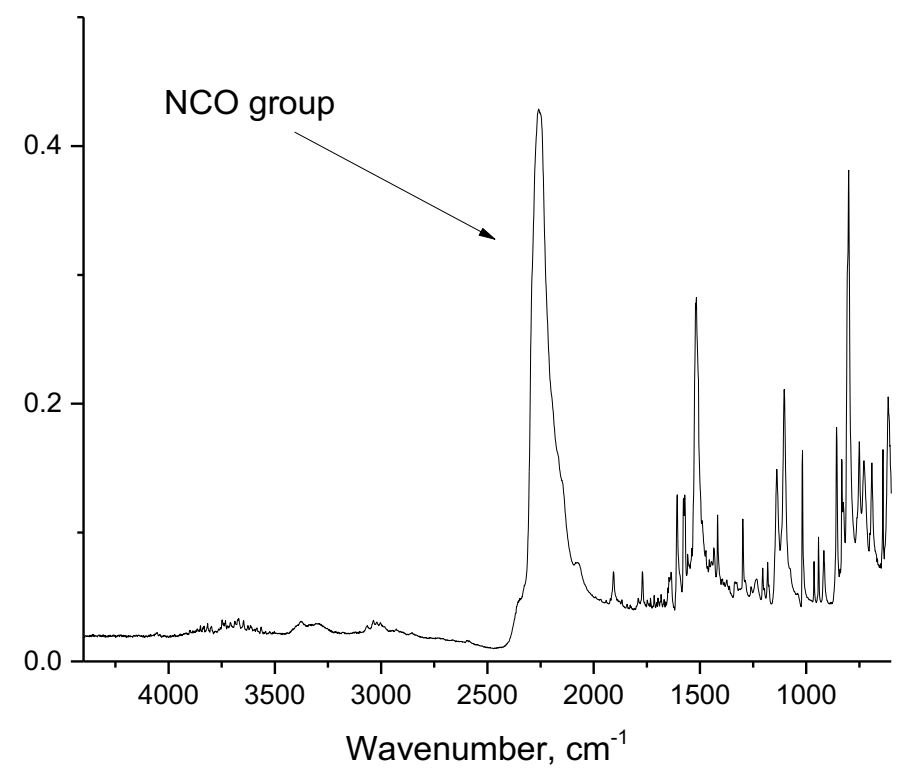

Figure S51: FT-IR of synthesized 1,4-phenylene diisocyanate

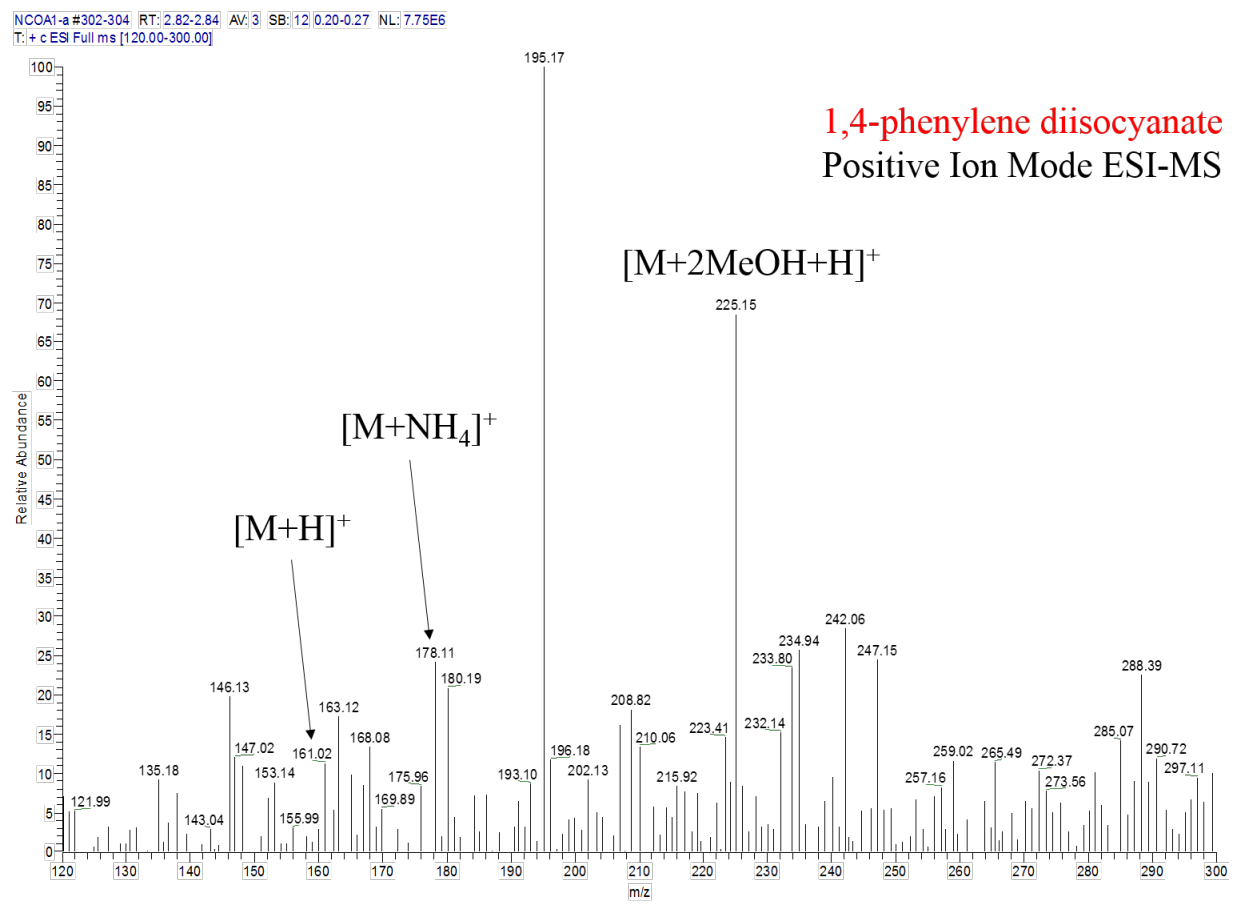

Figure S52: ESI MS of synthesized 1,4-phenylene diisocyanate 


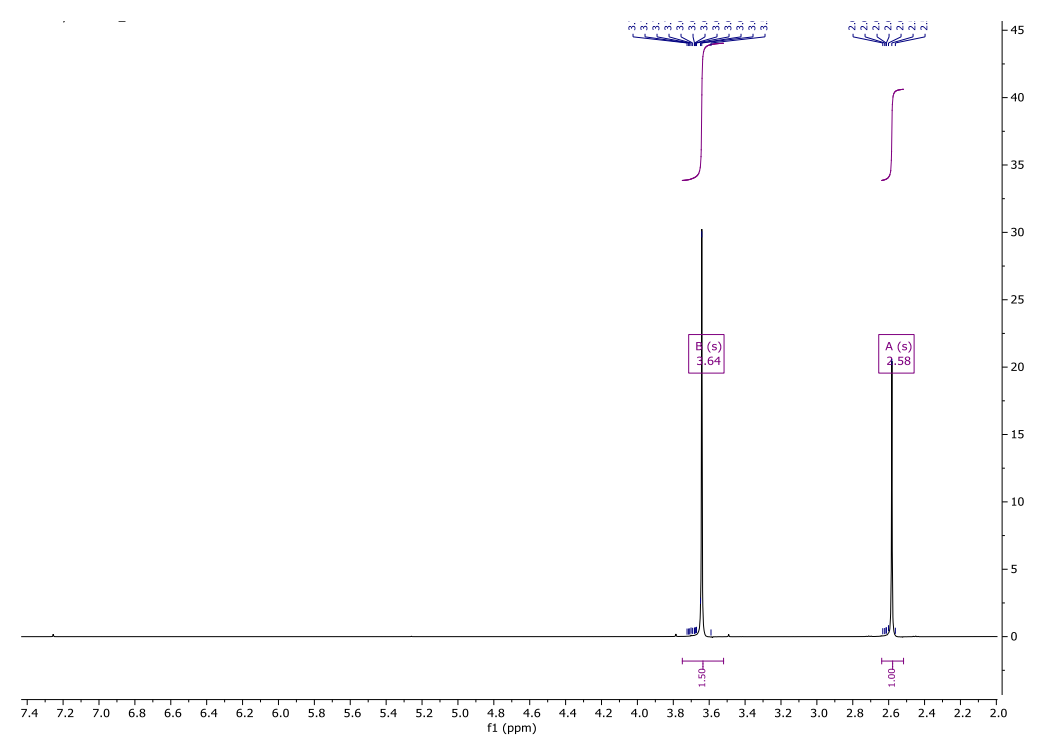

Figure S53: ${ }^{1} \mathrm{H}$ NMR of dimethyl succinate

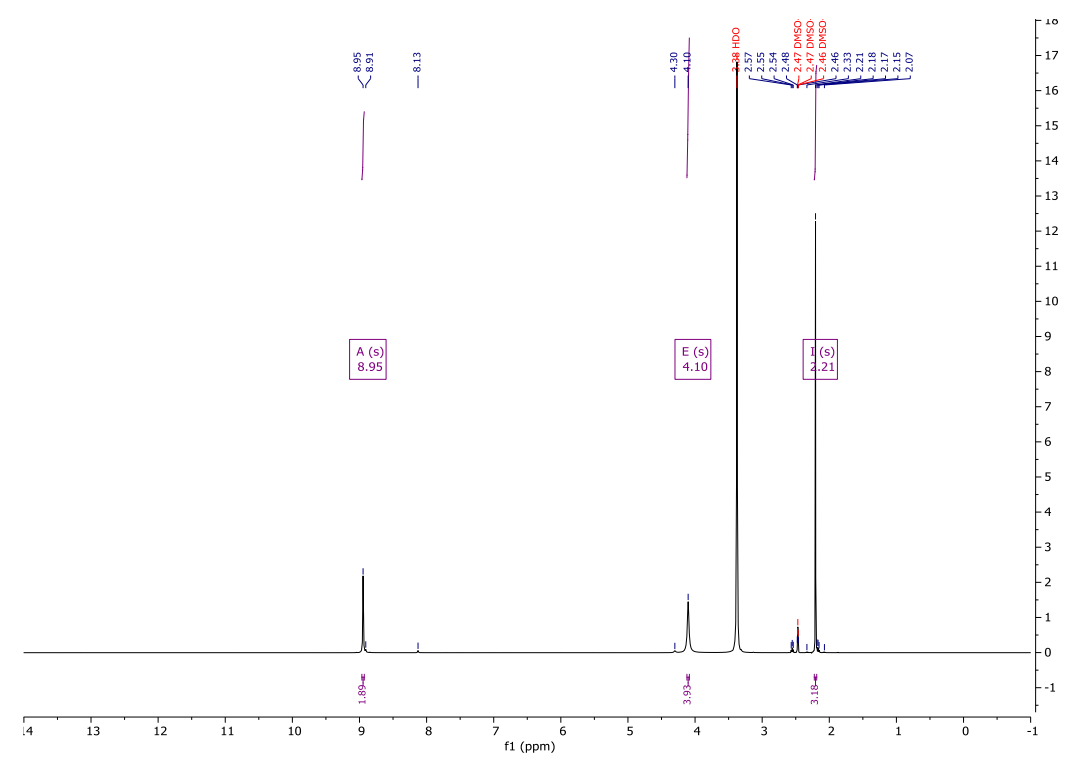

Figure S54: ${ }^{1} \mathrm{H}$ NMR of succinic acid dihydrazide 


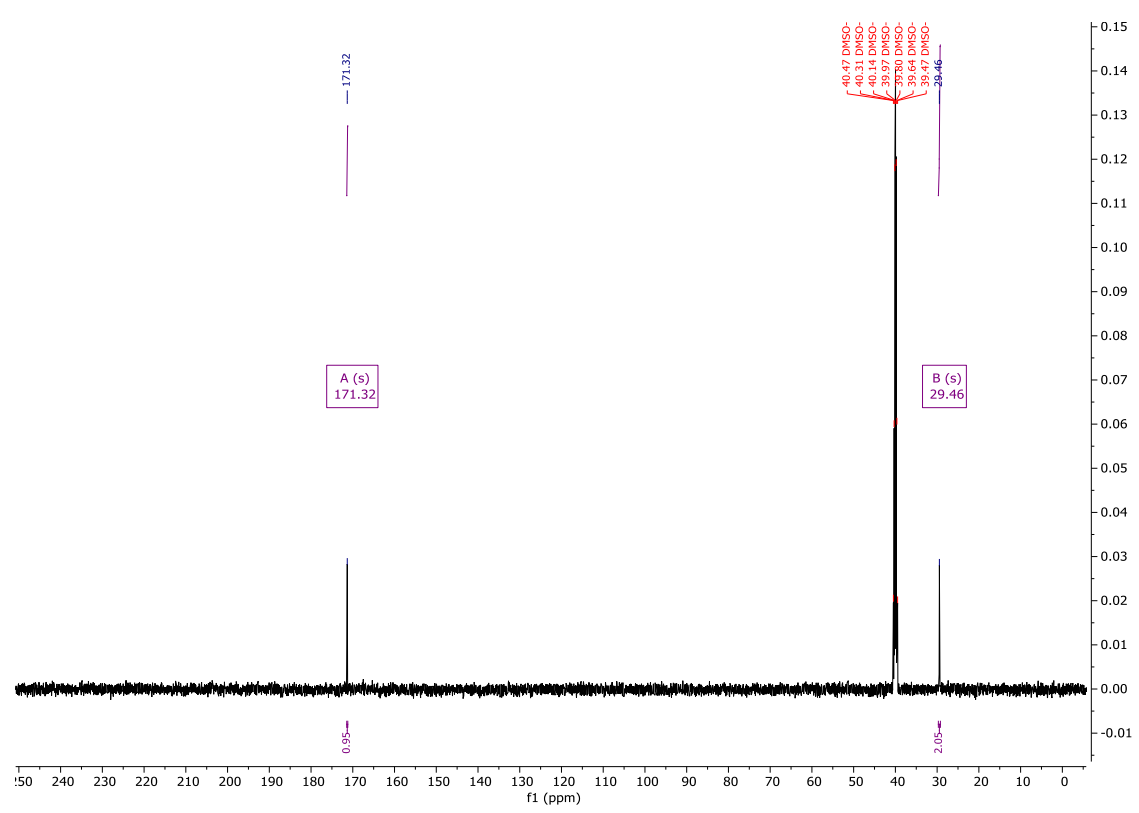

Figure S55: ${ }^{13} \mathrm{C}$ NMR of succinic acid dihydrazide

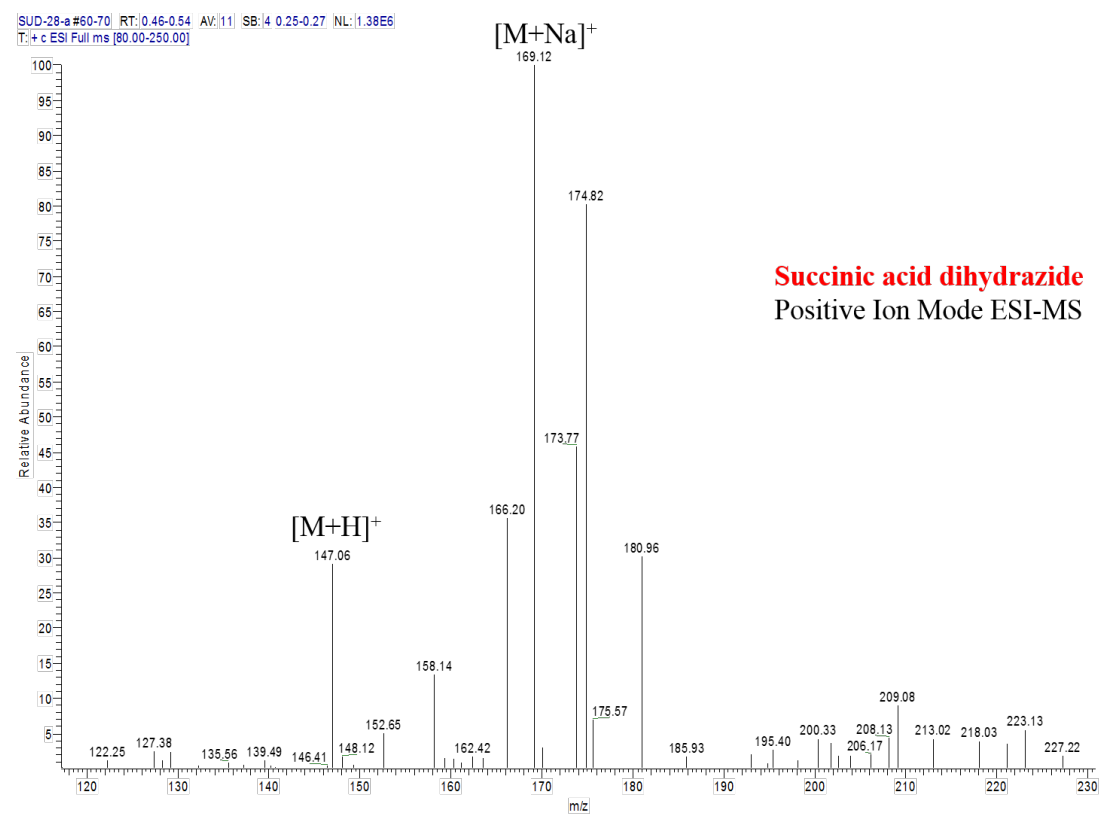

Figure S56: ESI MS of succinic acid dihydrazide 


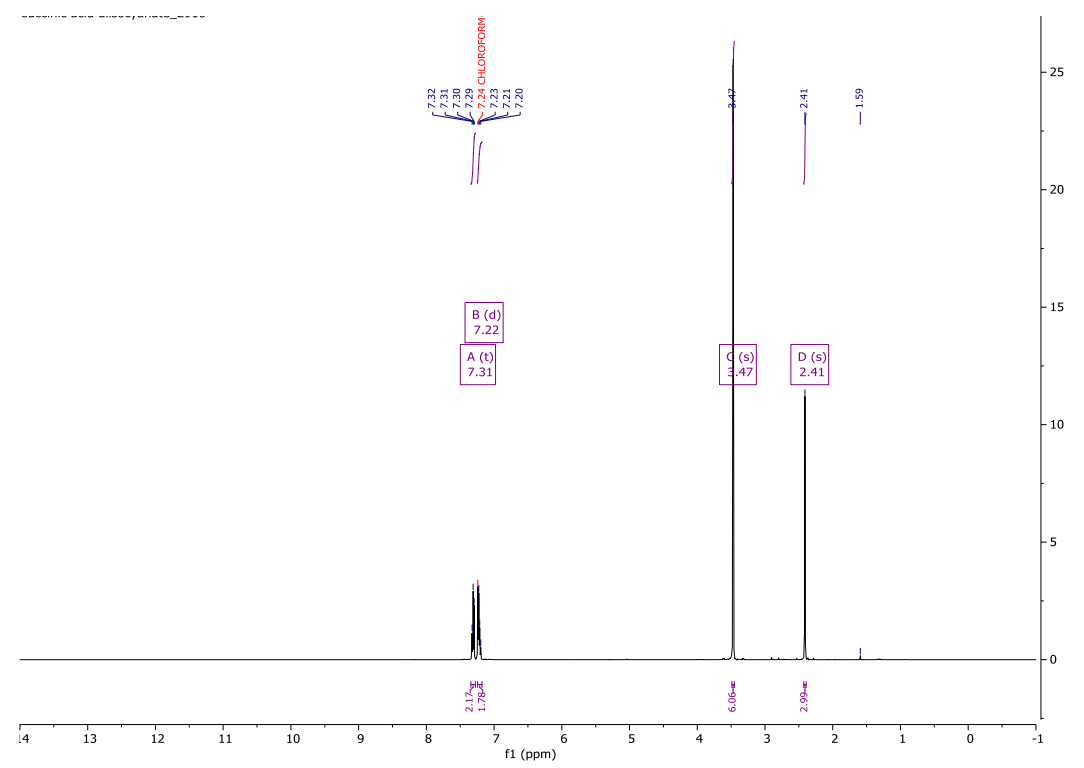

Figure S57: ${ }^{1} \mathrm{H}$ NMR of ethylene diisocyanate

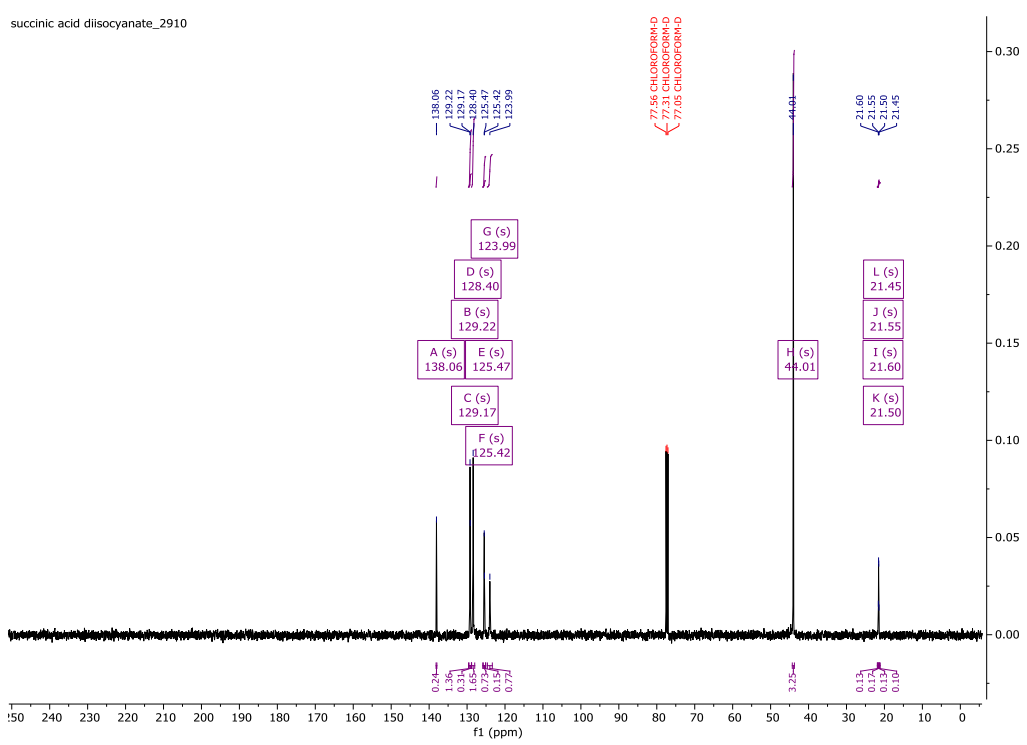

Figure S58: ${ }^{13} \mathrm{C}$ NMR of ethylene diisocyanate 


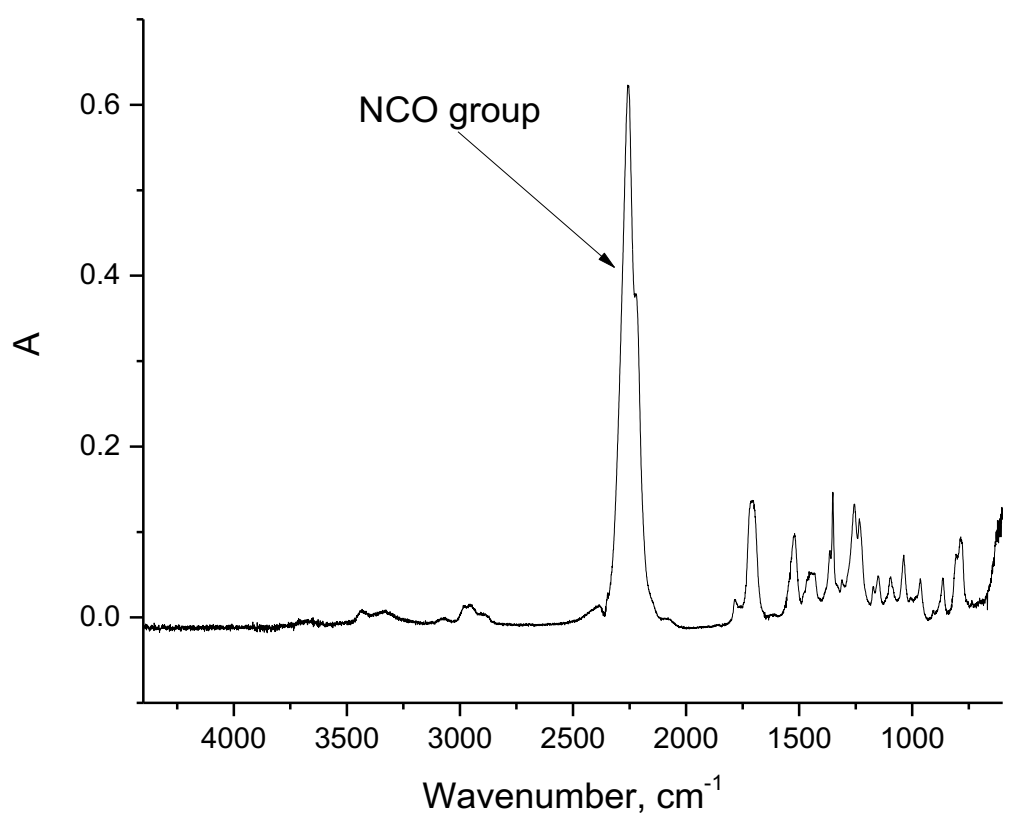

Figure S59: FT-IR of ethylene diisocyanate

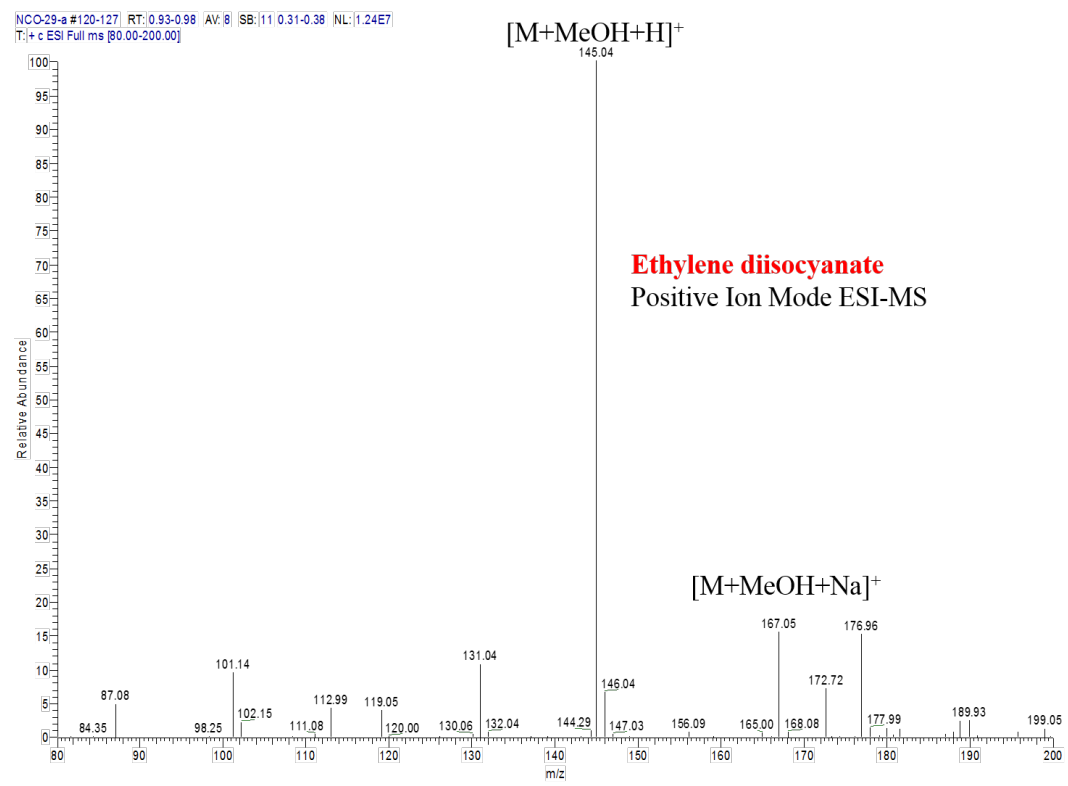

Figure S60: ESI MS of ethylene diisocyanate 


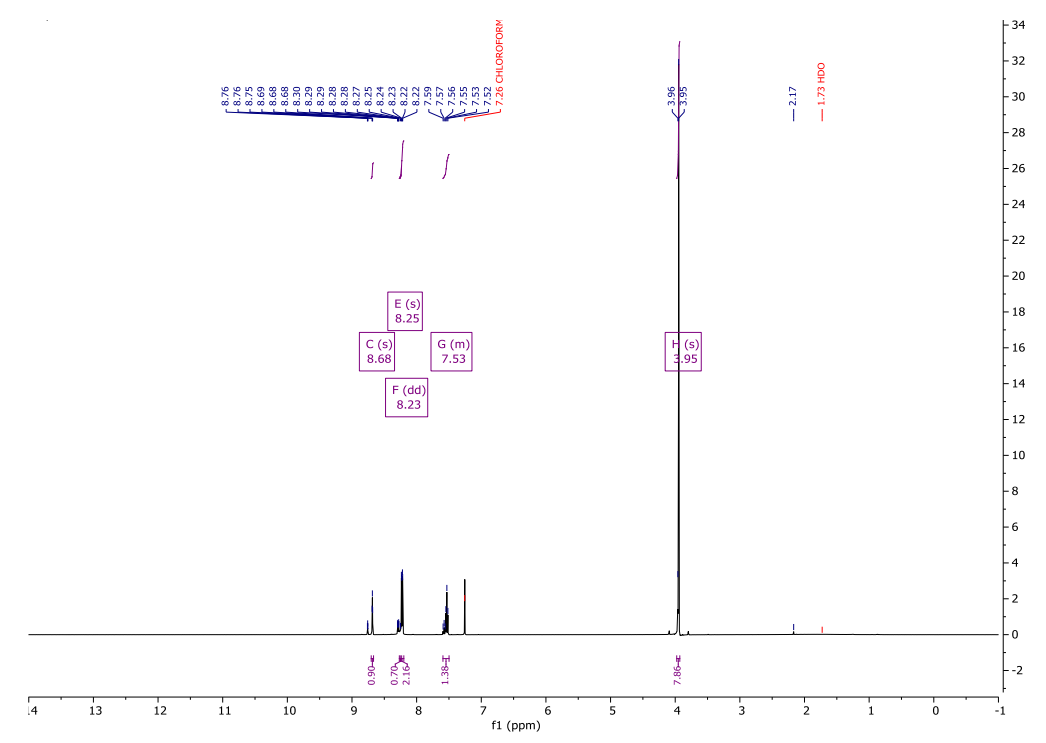

Figure S61: ${ }^{1} \mathrm{H}$ NMR of dimethyl isophthalate

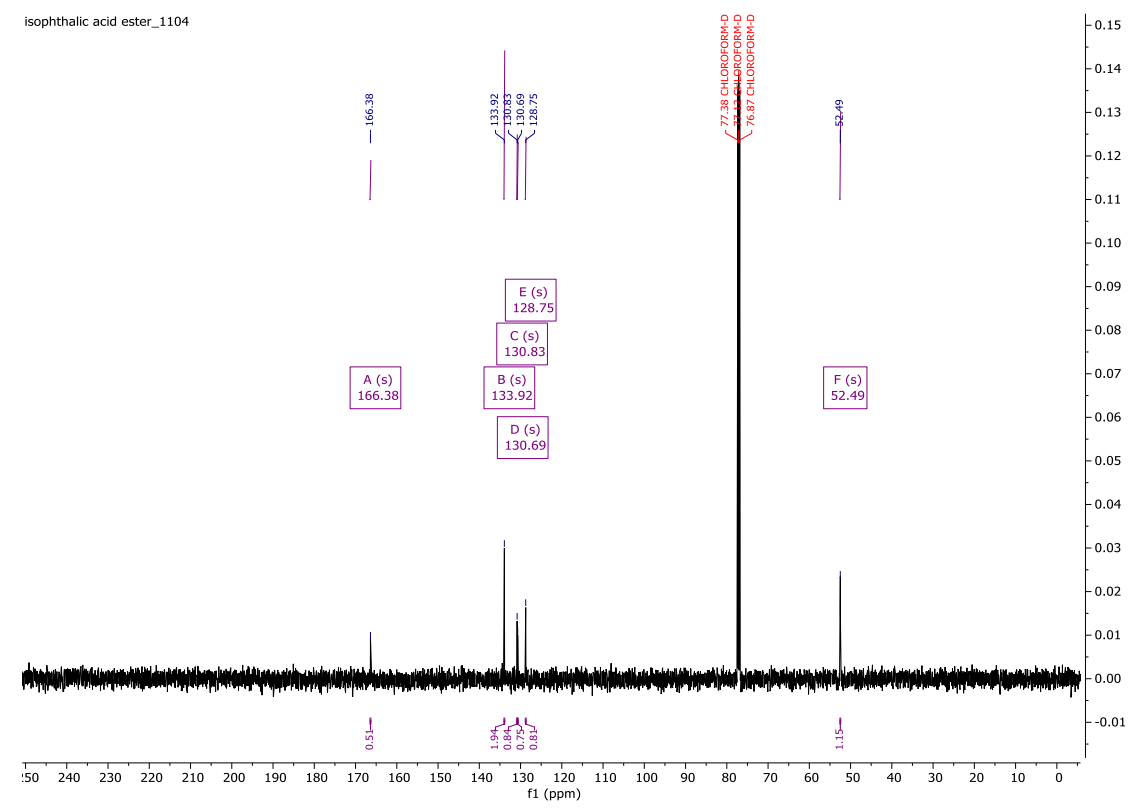

Figure S62: ${ }^{13} \mathrm{C}$ NMR of dimethyl isophthalate 


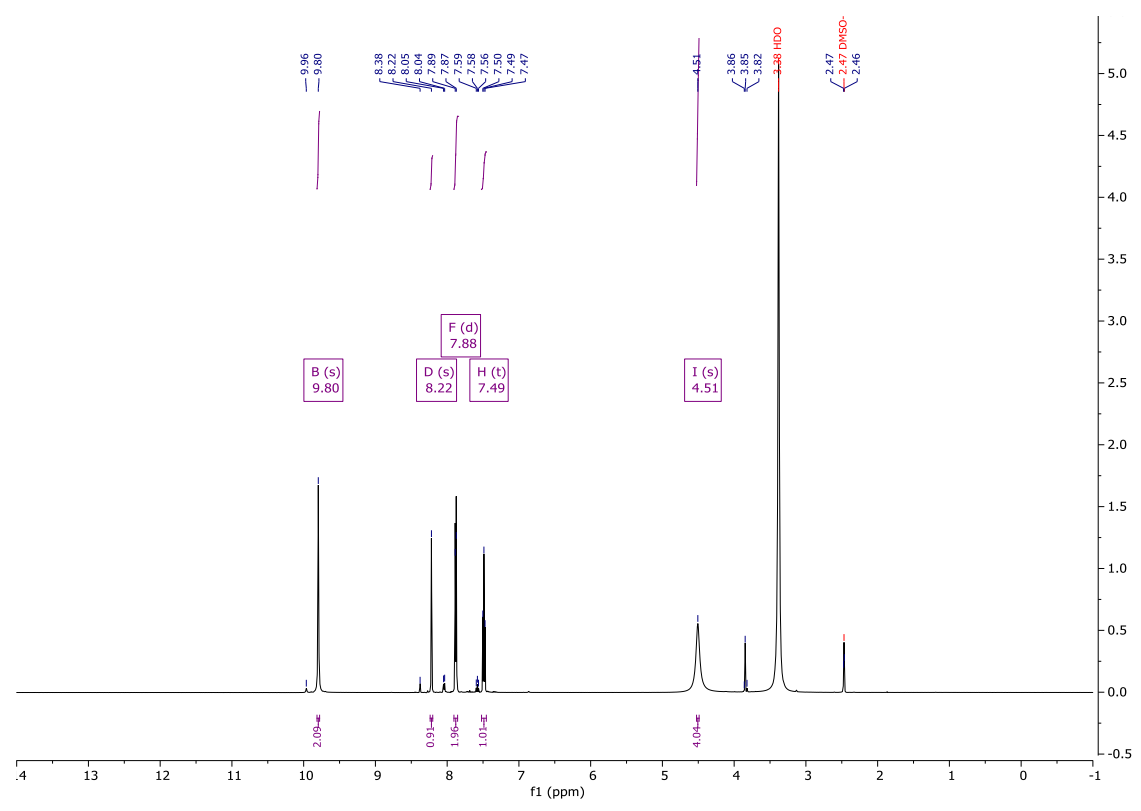

Figure S63: ${ }^{1} \mathrm{H}$ NMR of isophthalic dihydrazide

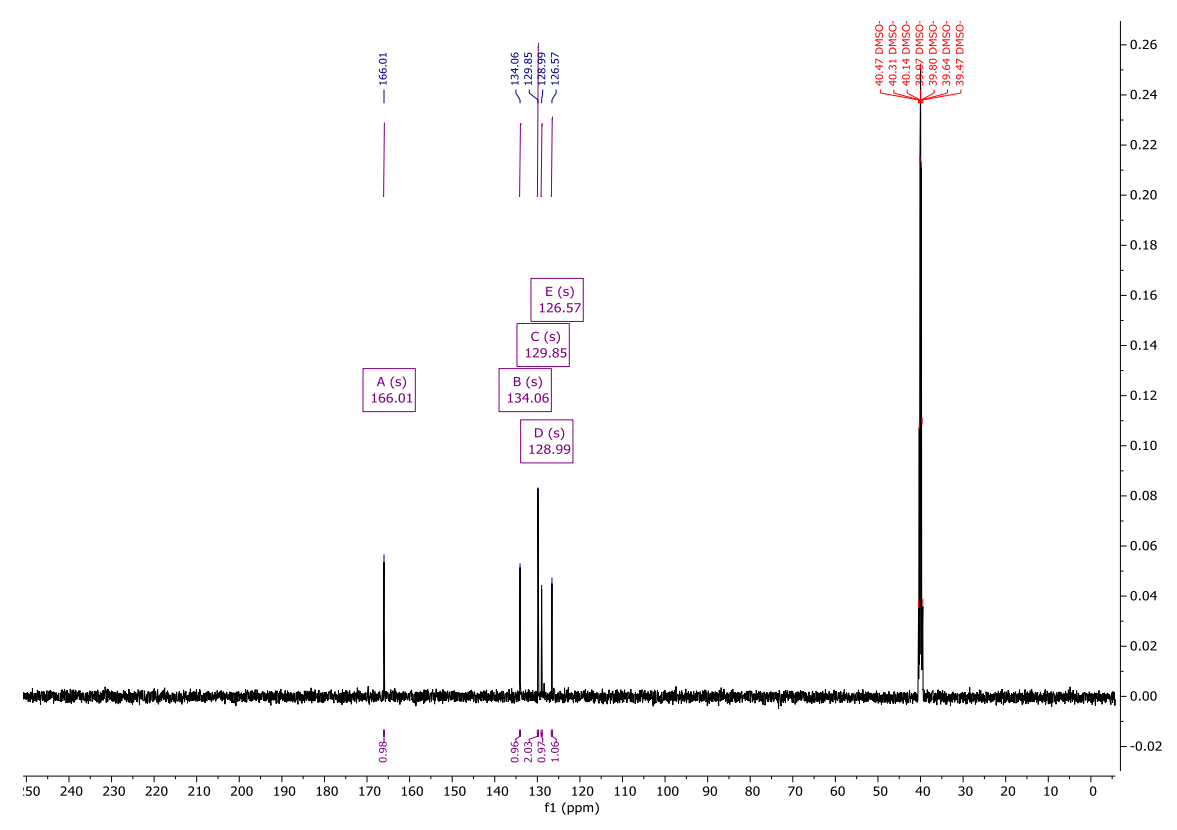

Figure S64: ${ }^{13} \mathrm{C}$ NMR of isophthalic dihydrazide 


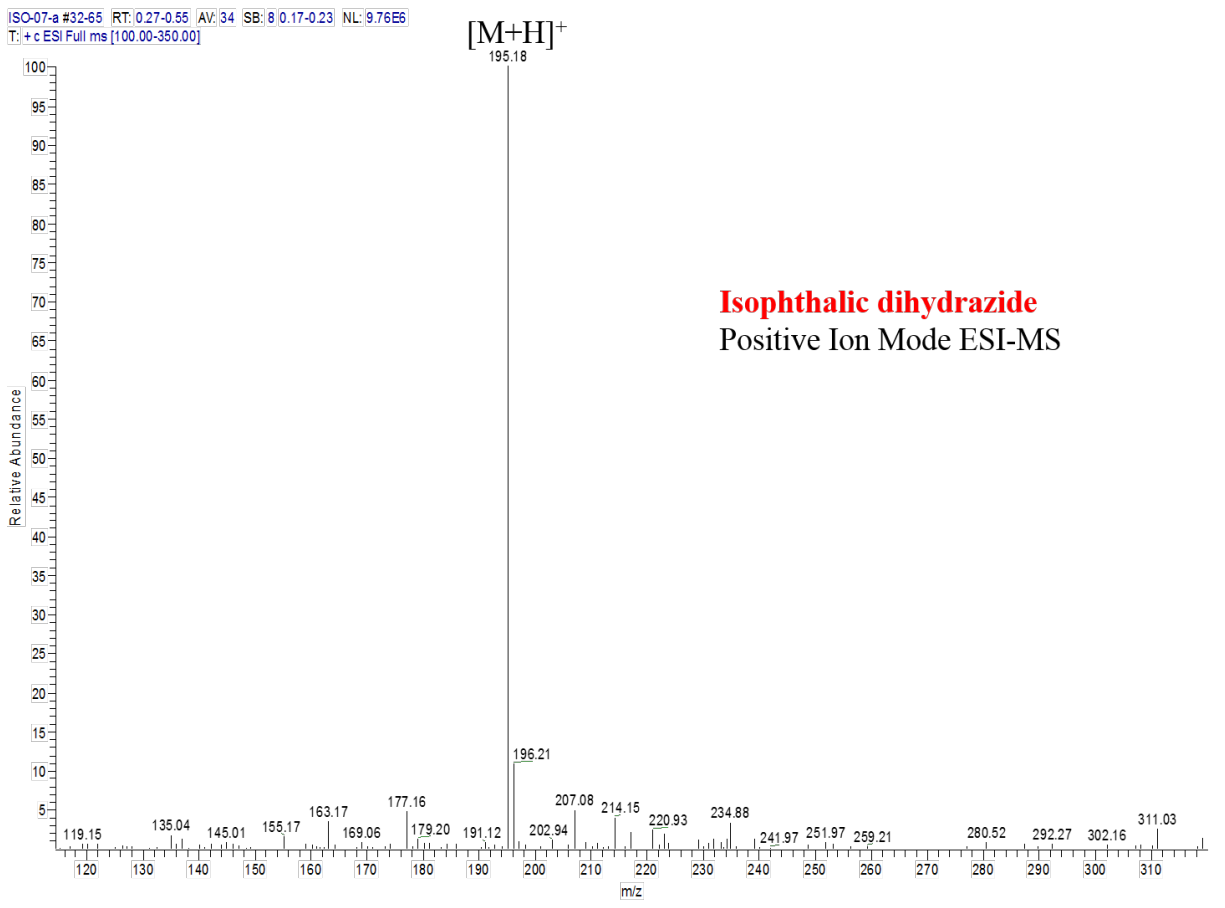

Figure S65: ESI MS of isophthalic dihydrazide

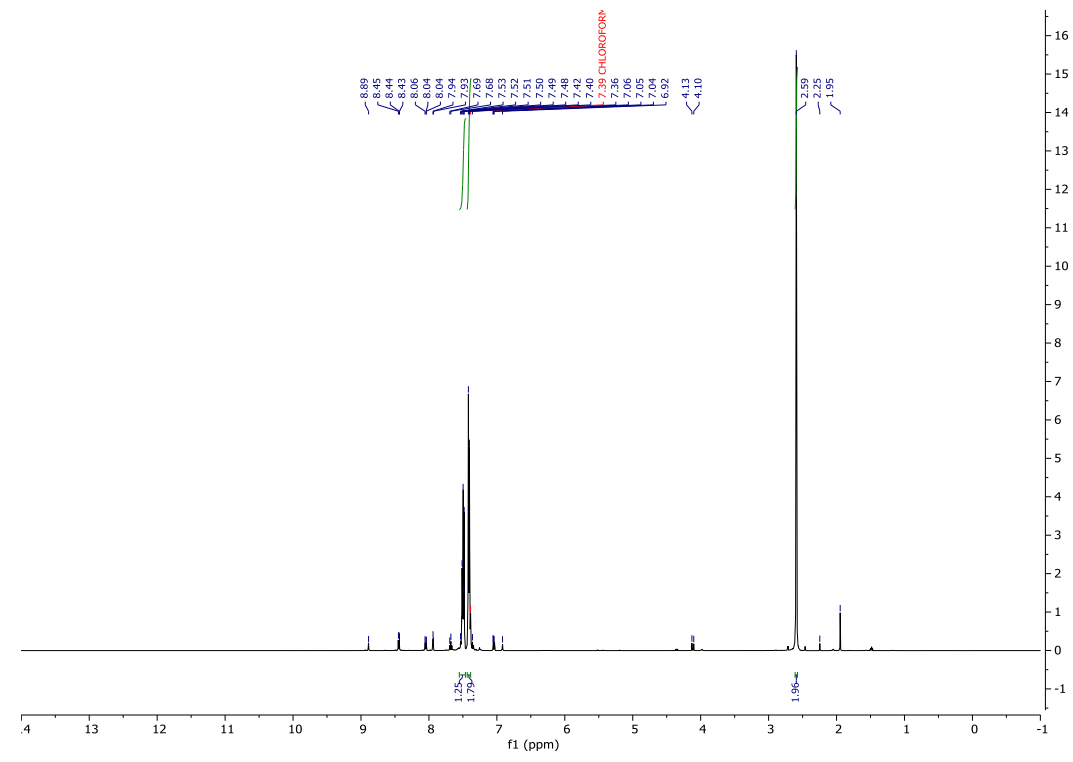

Figure S66: ${ }^{1} \mathrm{H}$ NMR of 1,3-phenylene diisocyanate 


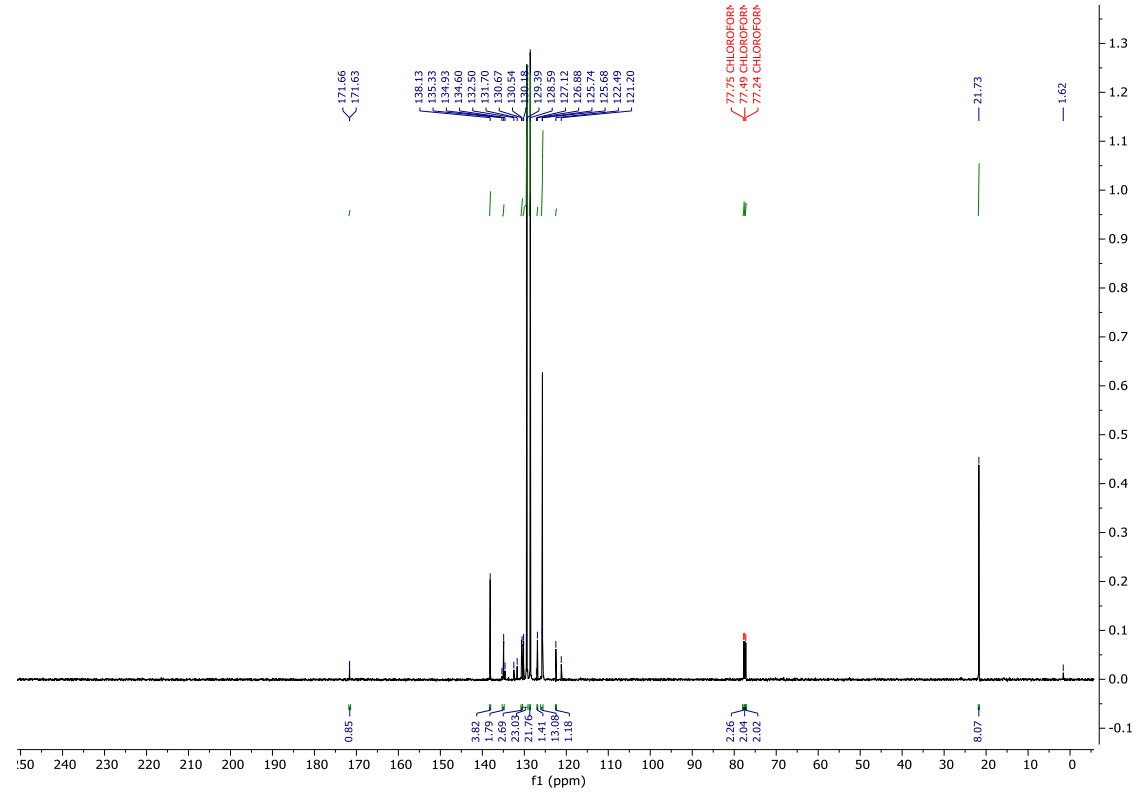

Figure S67: ${ }^{13} \mathrm{C}$ NMR of 1,3-phenylene diisocyanate

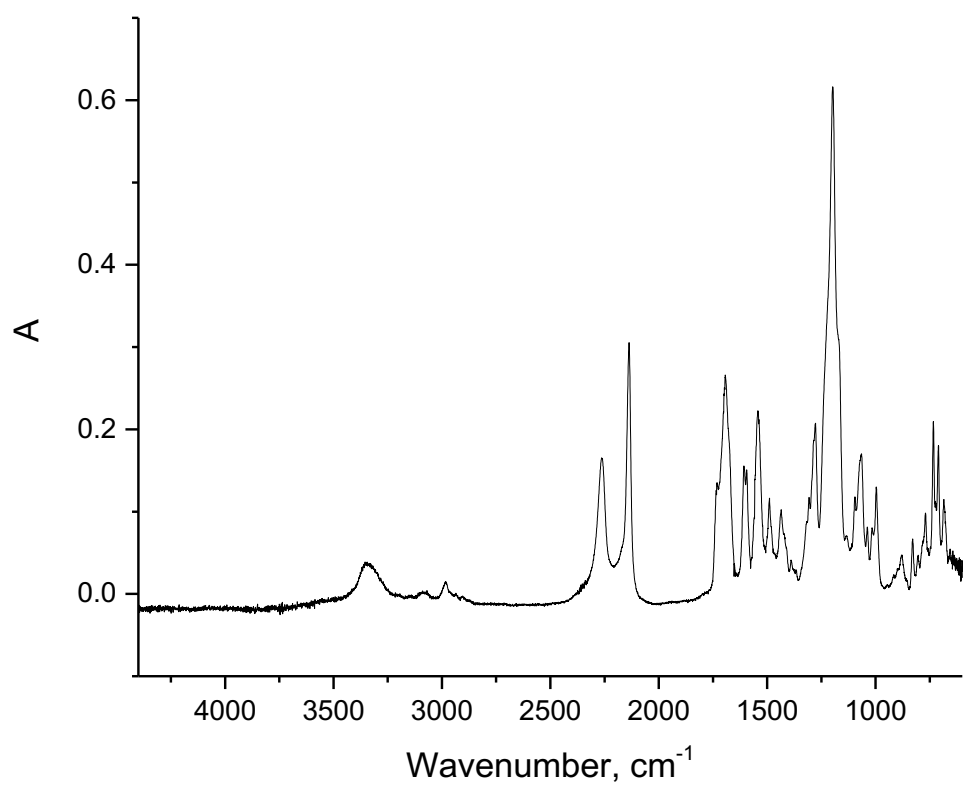

Figure S68: FT-IR of 1,3-phenylene diisocyanate 


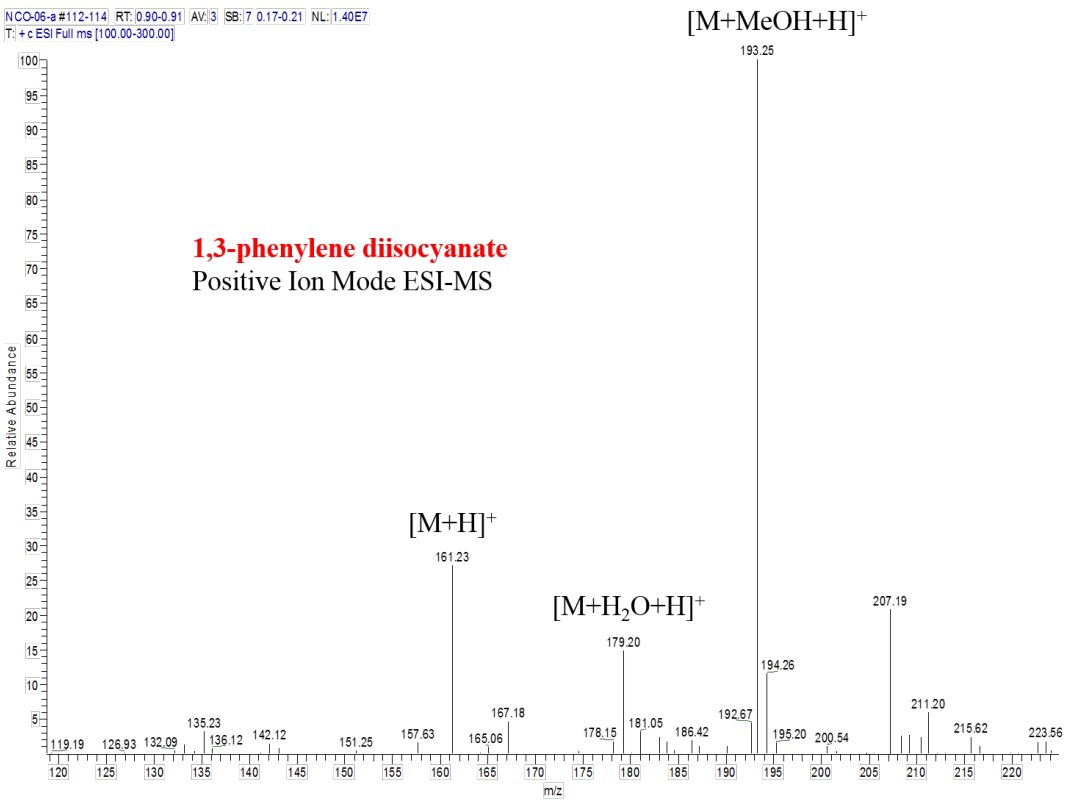

Figure S69: ESI MS of 1,3-phenylene diisocyanate

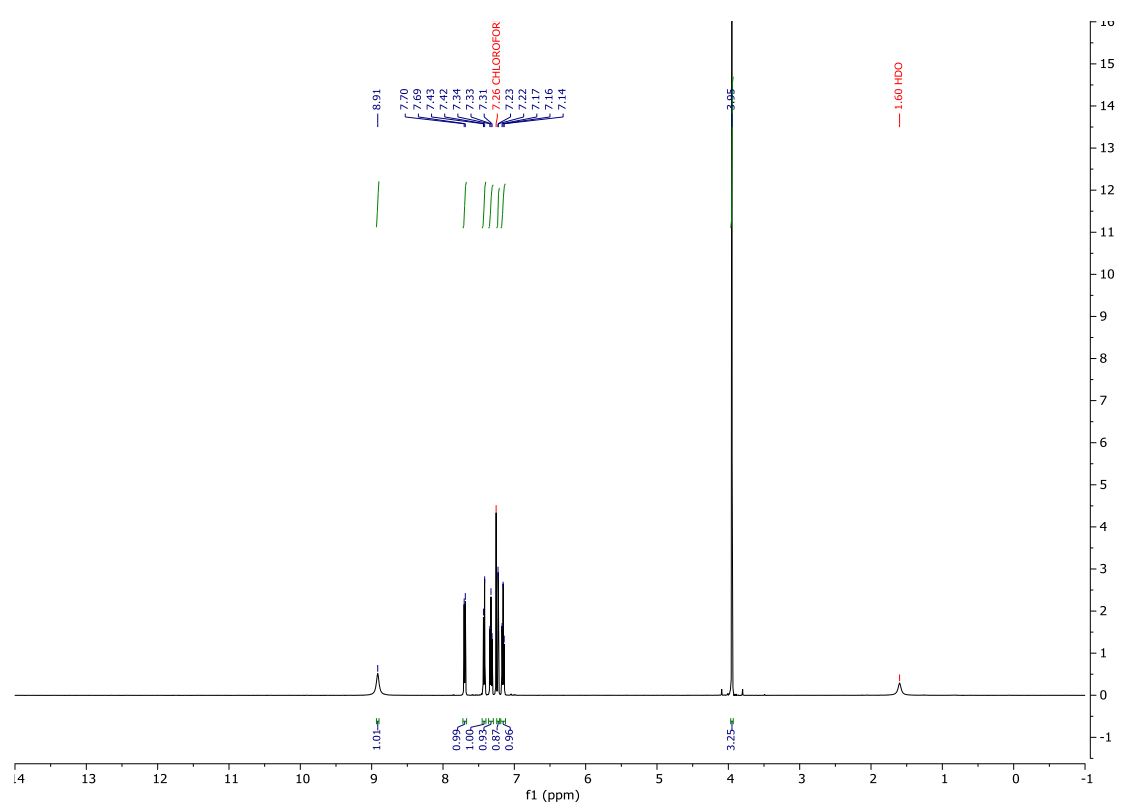

Figure S70: ${ }^{1} \mathrm{H}$ NMR of methyl 2-indolecarboxylate 


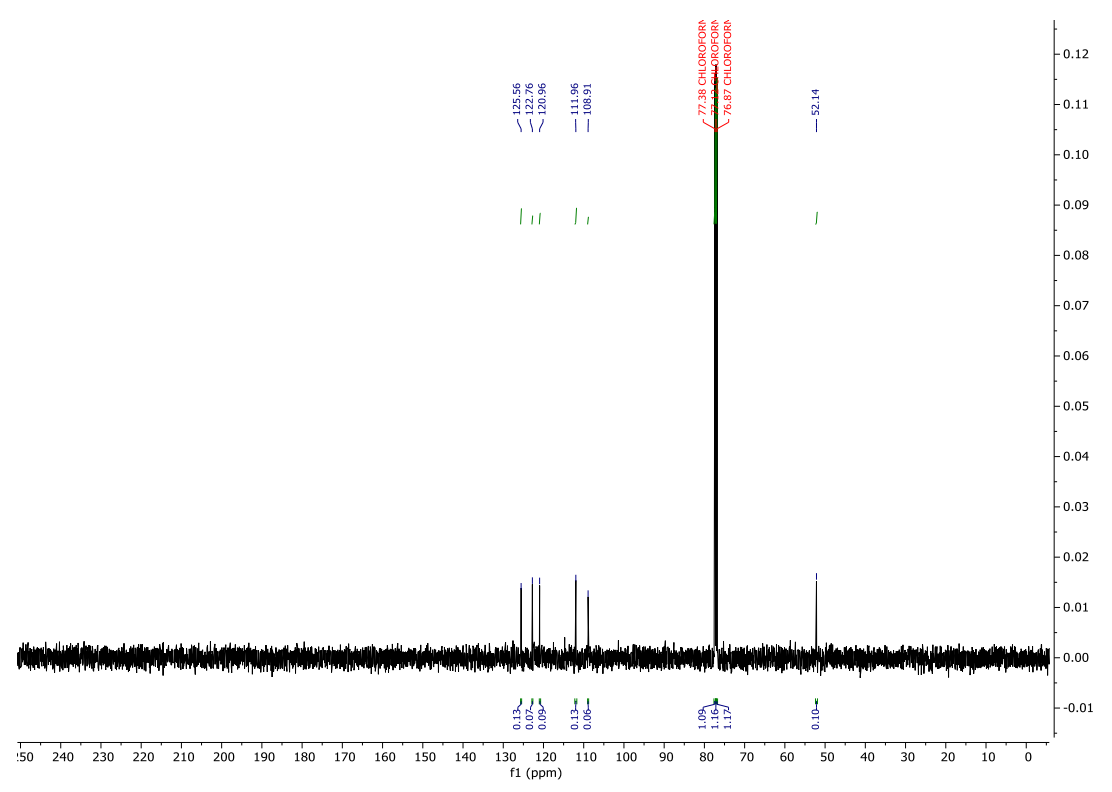

Figure S71: ${ }^{13} \mathrm{C}$ NMR of methyl 2-indolecarboxylate

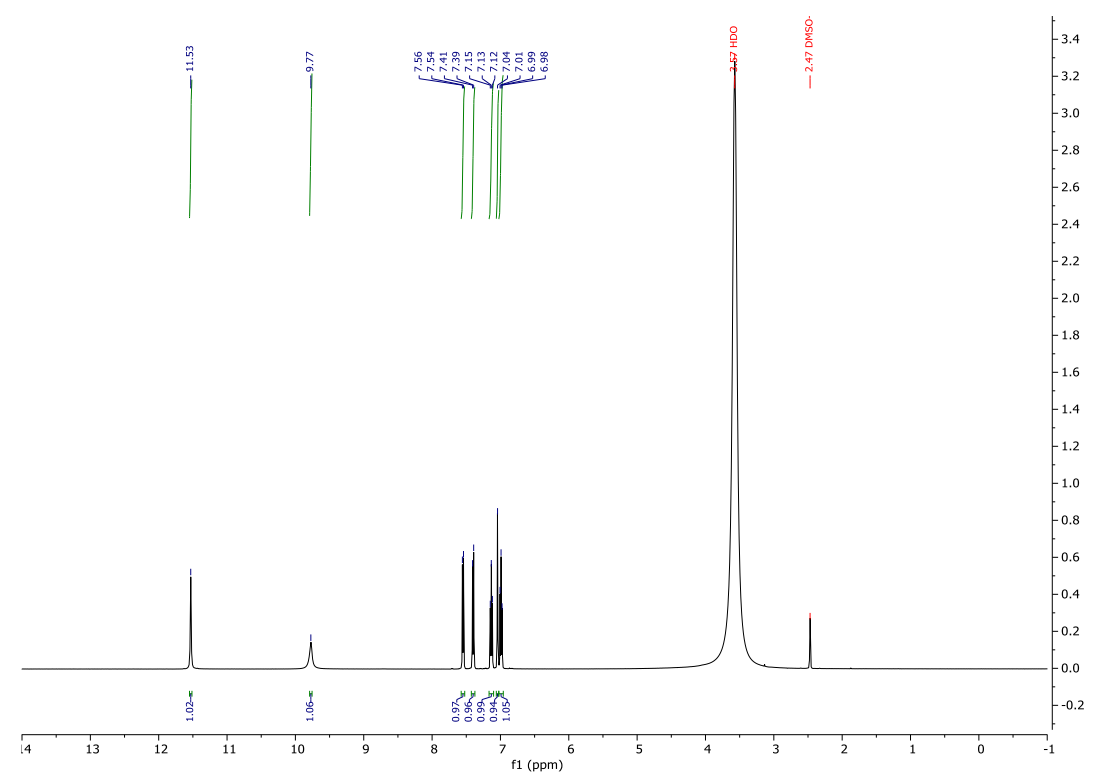

Figure S72: ${ }^{1} \mathrm{H}$ NMR of 2-Indolecarboxylic hydrazide 


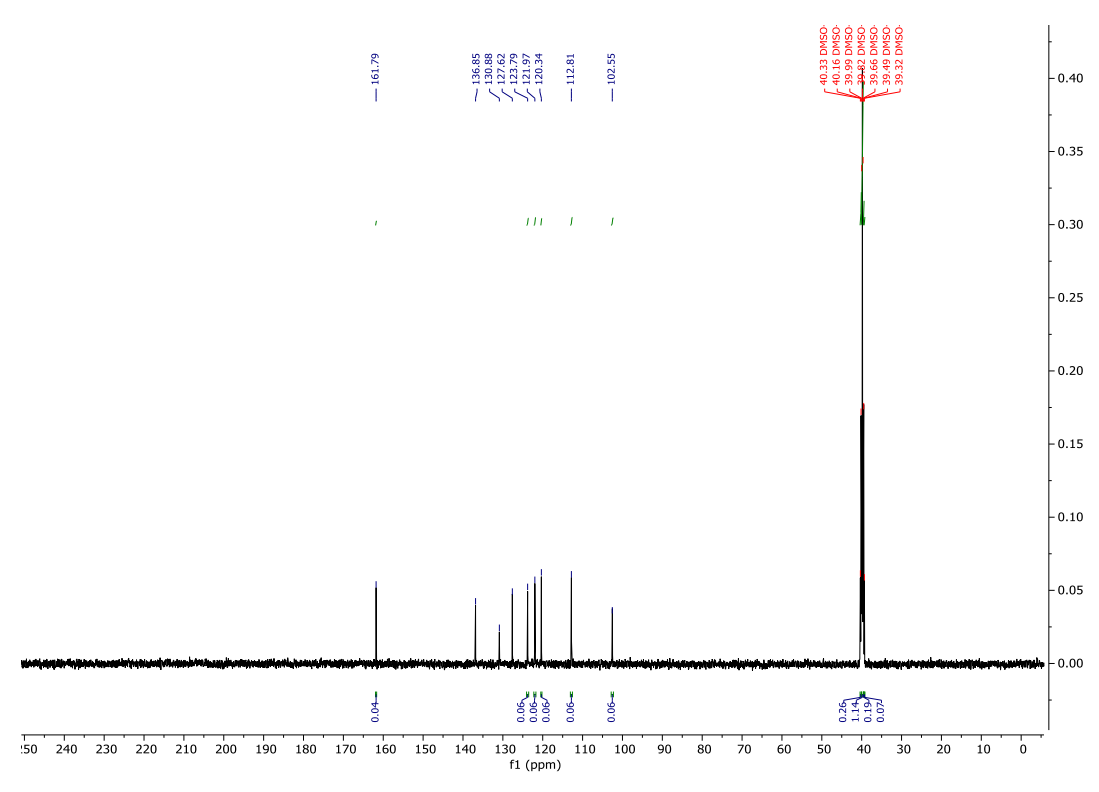

Figure S73: ${ }^{13} \mathrm{C}$ NMR of 2-Indolecarboxylic hydrazide

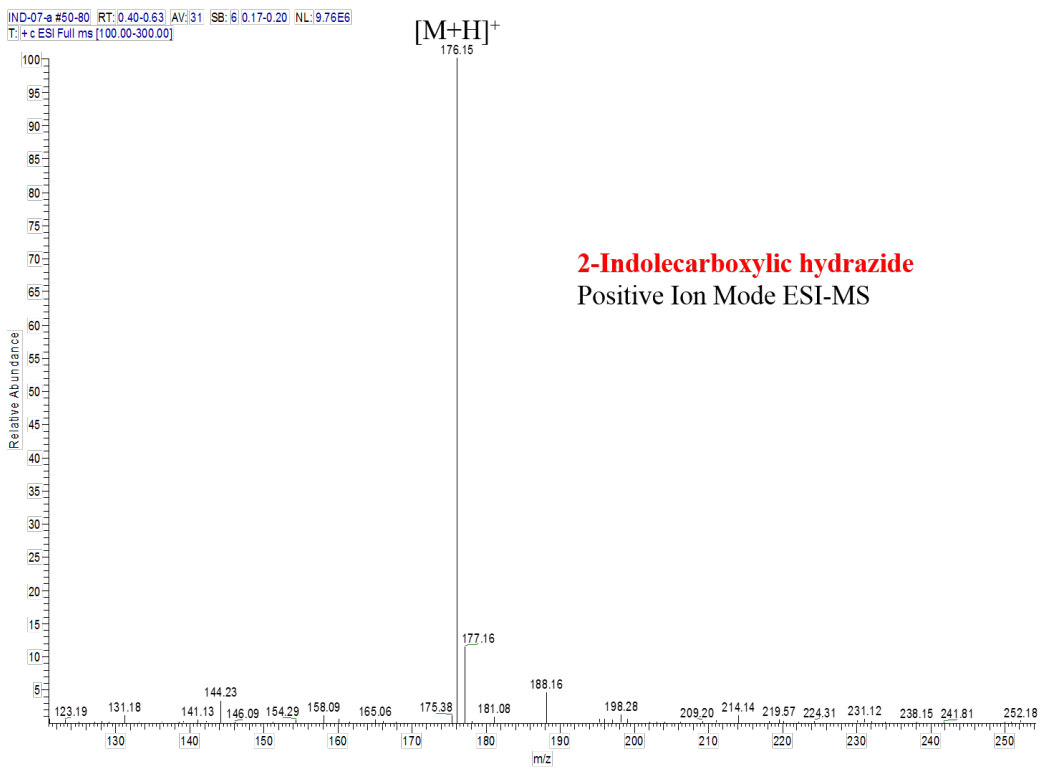

Figure S74: ESI MS of 2-Indolecarboxylic hydrazide 


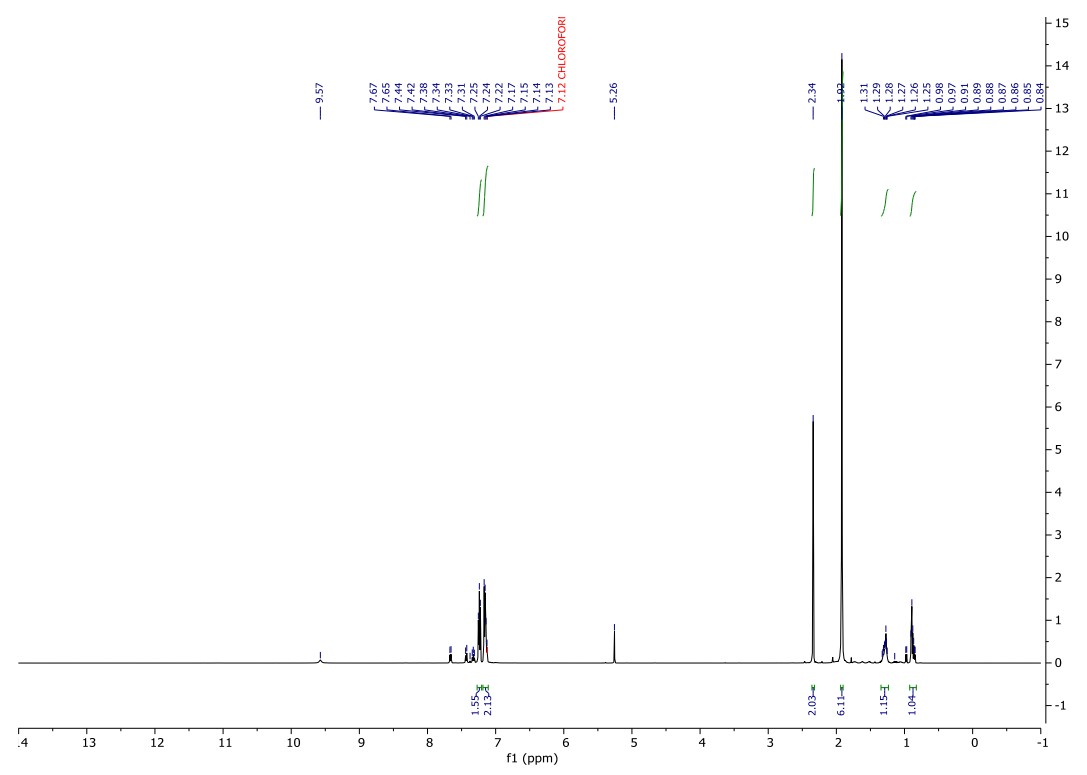

Figure S75: ${ }^{1} \mathrm{H}$ NMR of 2-Isocyanato -1H-indole

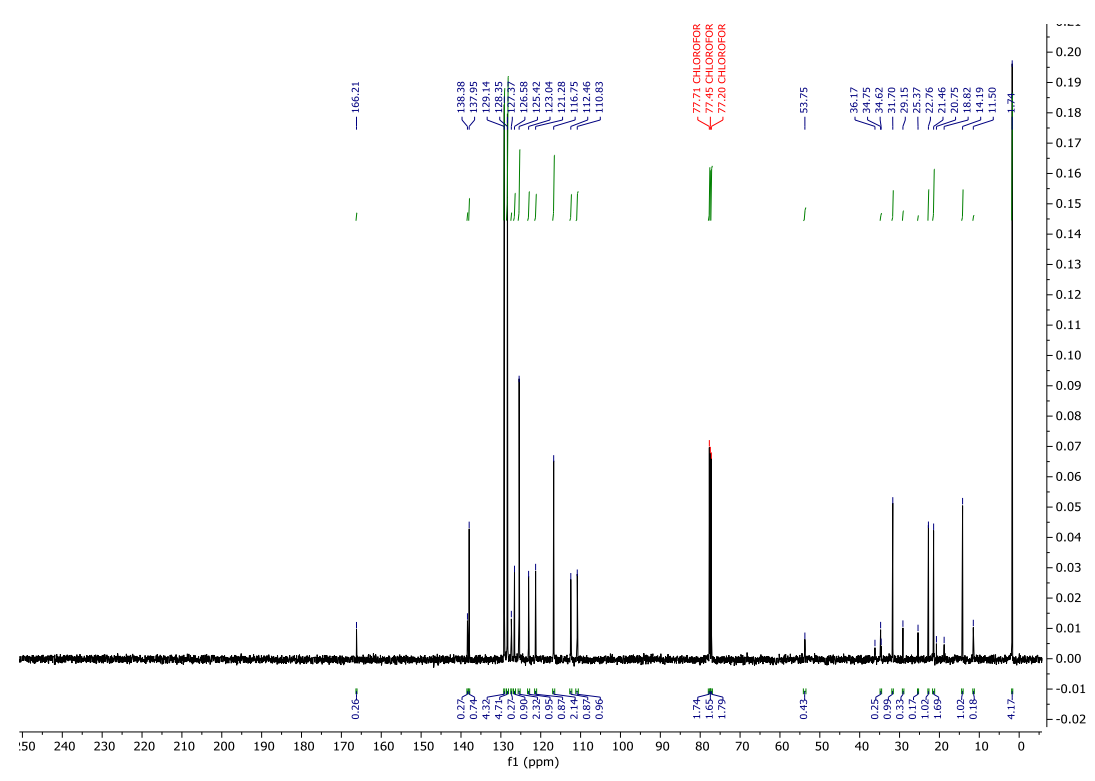

Figure S76: ${ }^{13} \mathrm{C}$ NMR of 2-Isocyanato $-1 \mathrm{H}$-indole 


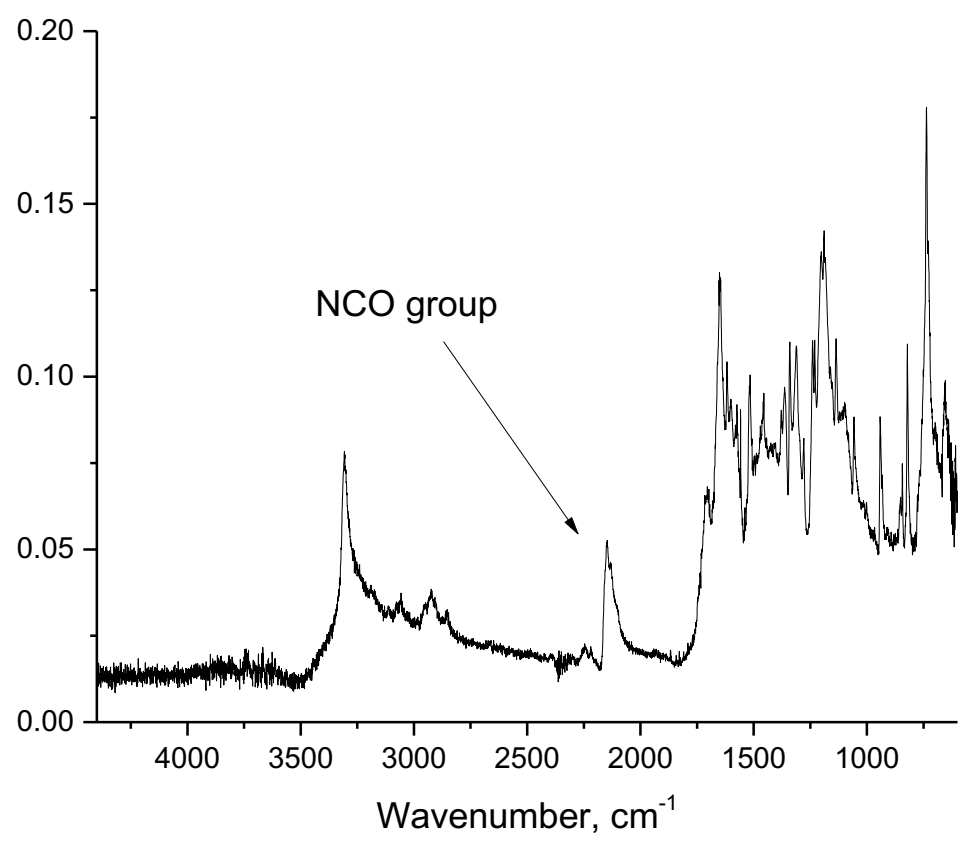

Figure S77: FT-IR of 2-Isocyanato -1H-indole

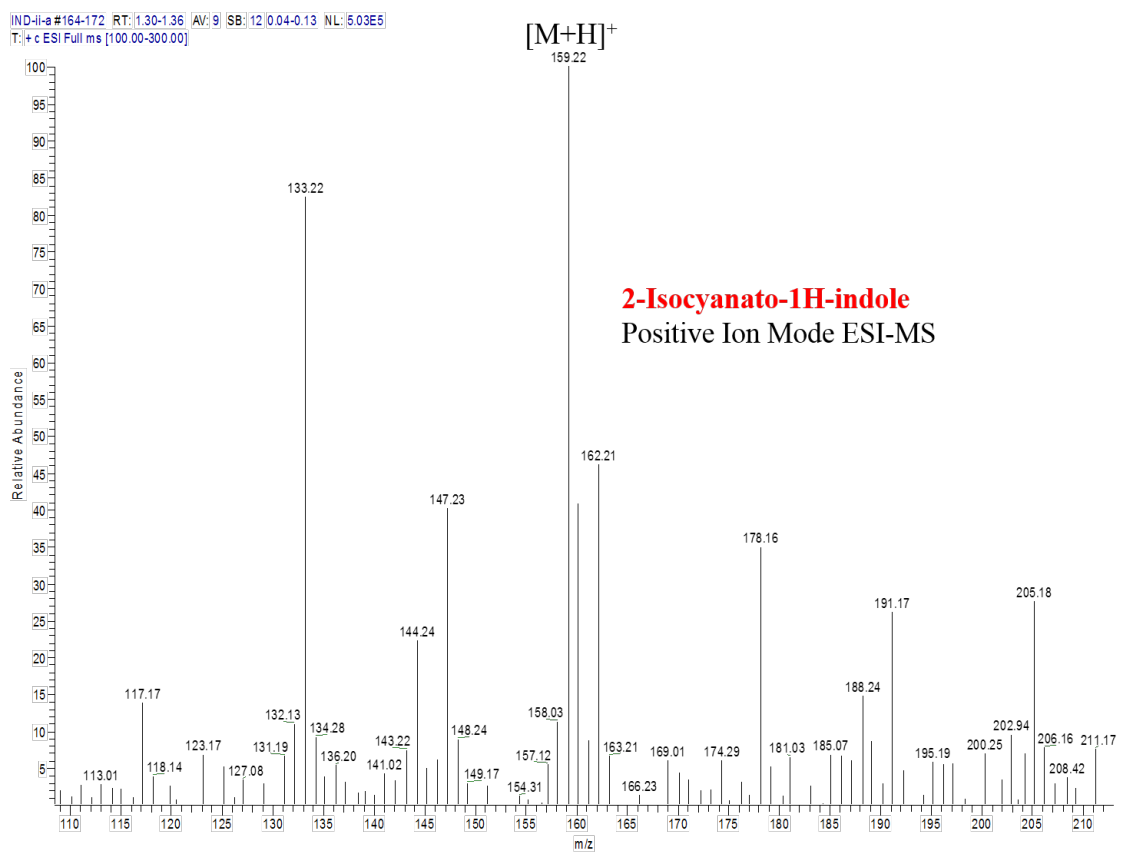

Figure S78: ESI MS of 2-Isocyanato -1H-indole 


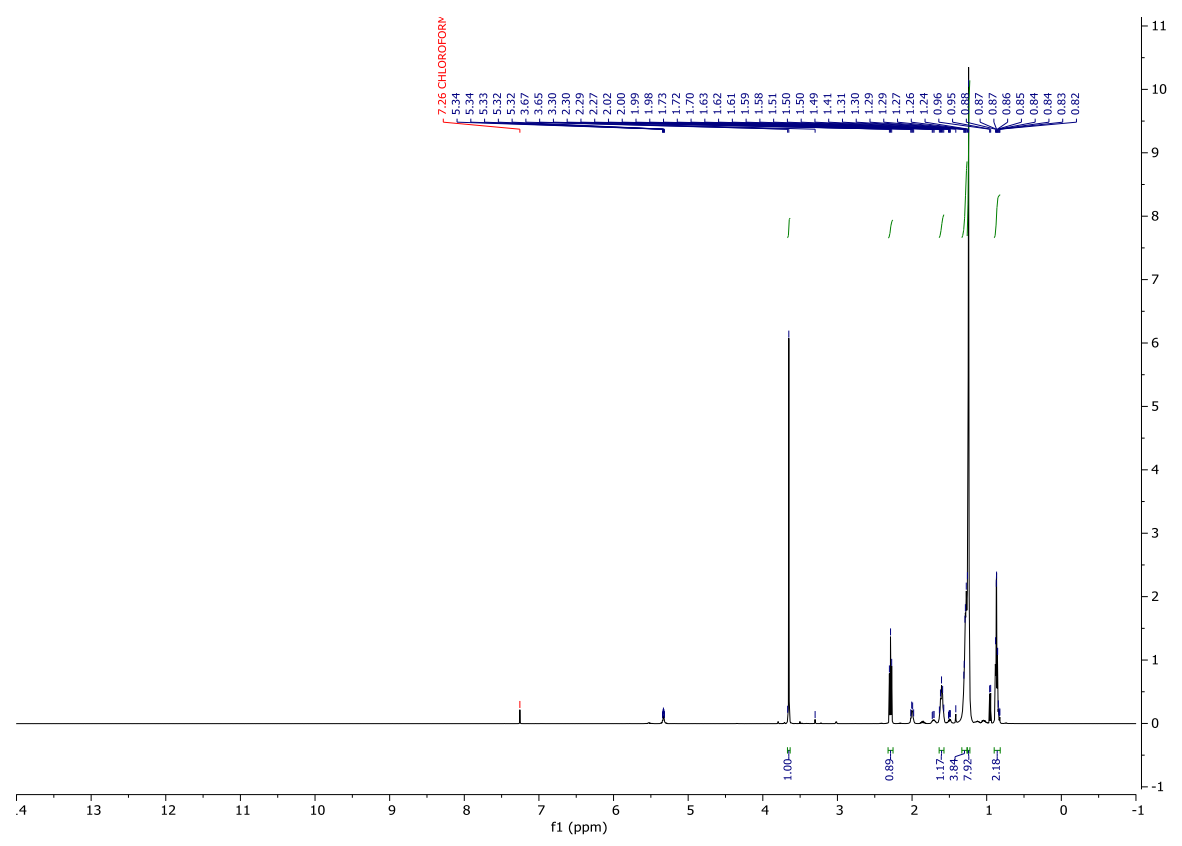

Figure S79: ${ }^{1} \mathrm{H}$ NMR of methyl palmitate

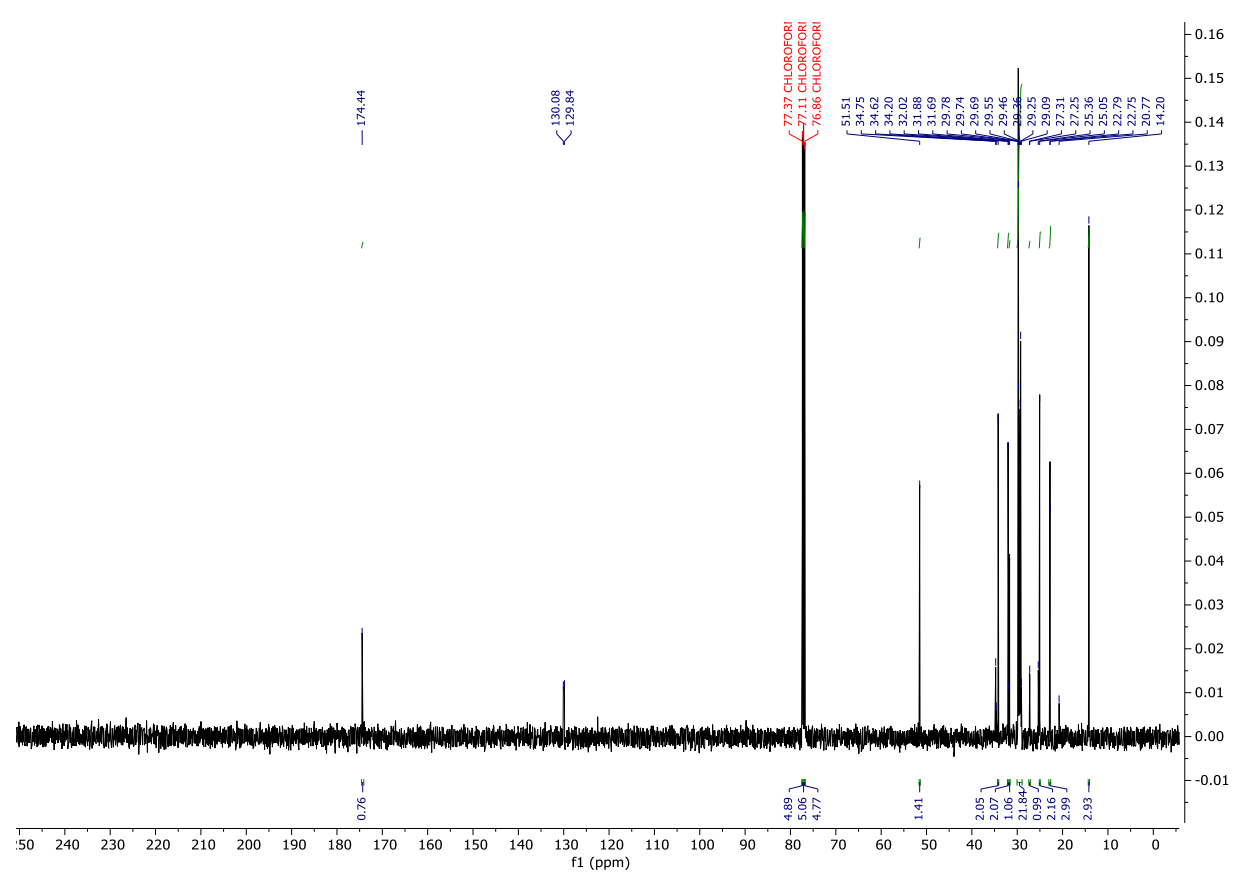

Figure S80: ${ }^{13} \mathrm{C}$ NMR of methyl palmitate 


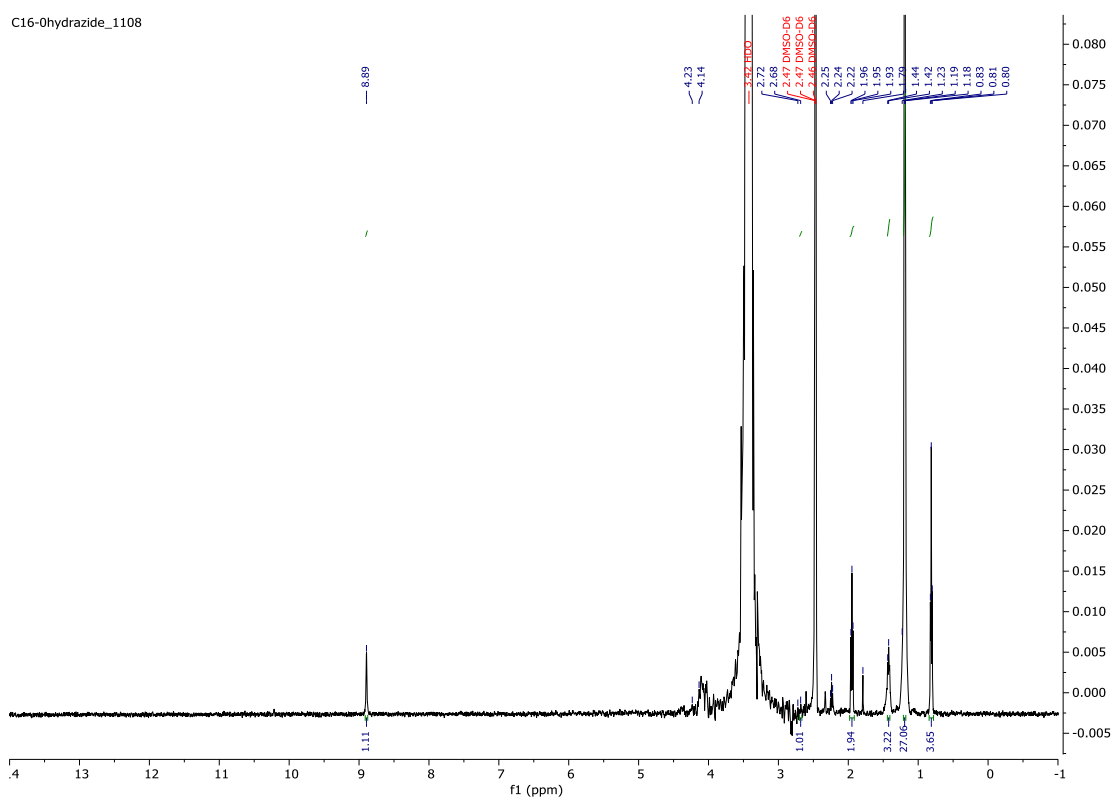

Figure S81: H NMR of palmitic hydrazide

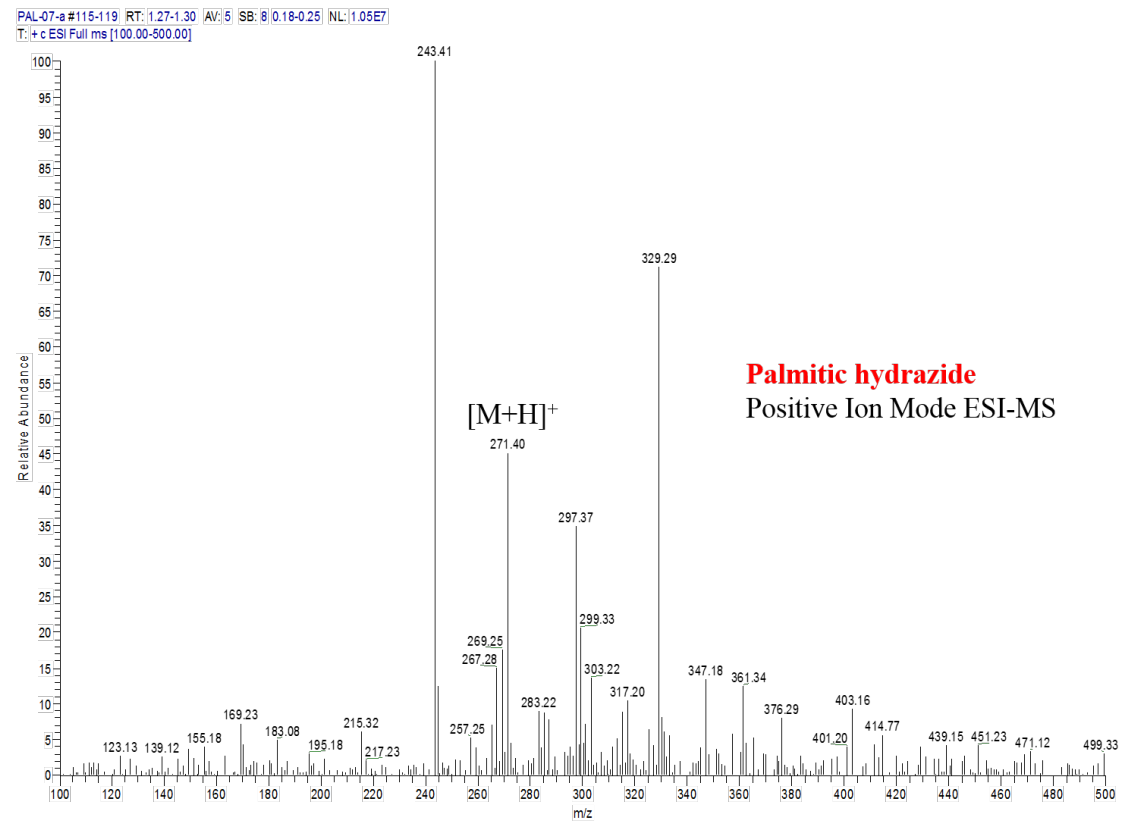

Figure S82: ESI MS of palmitic hydrazide 


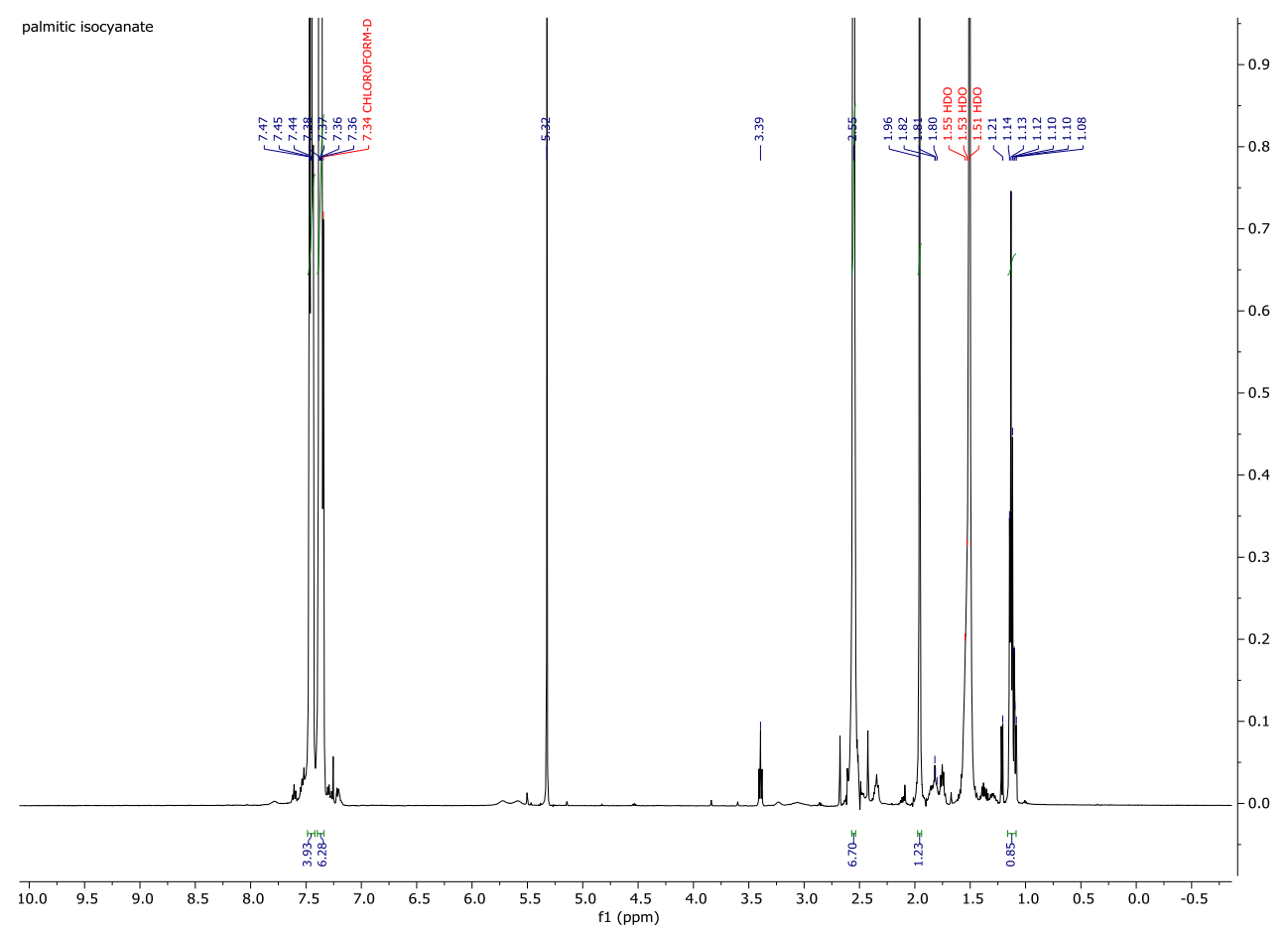

Figure S83: H NMR of hexadecyl isocyanate

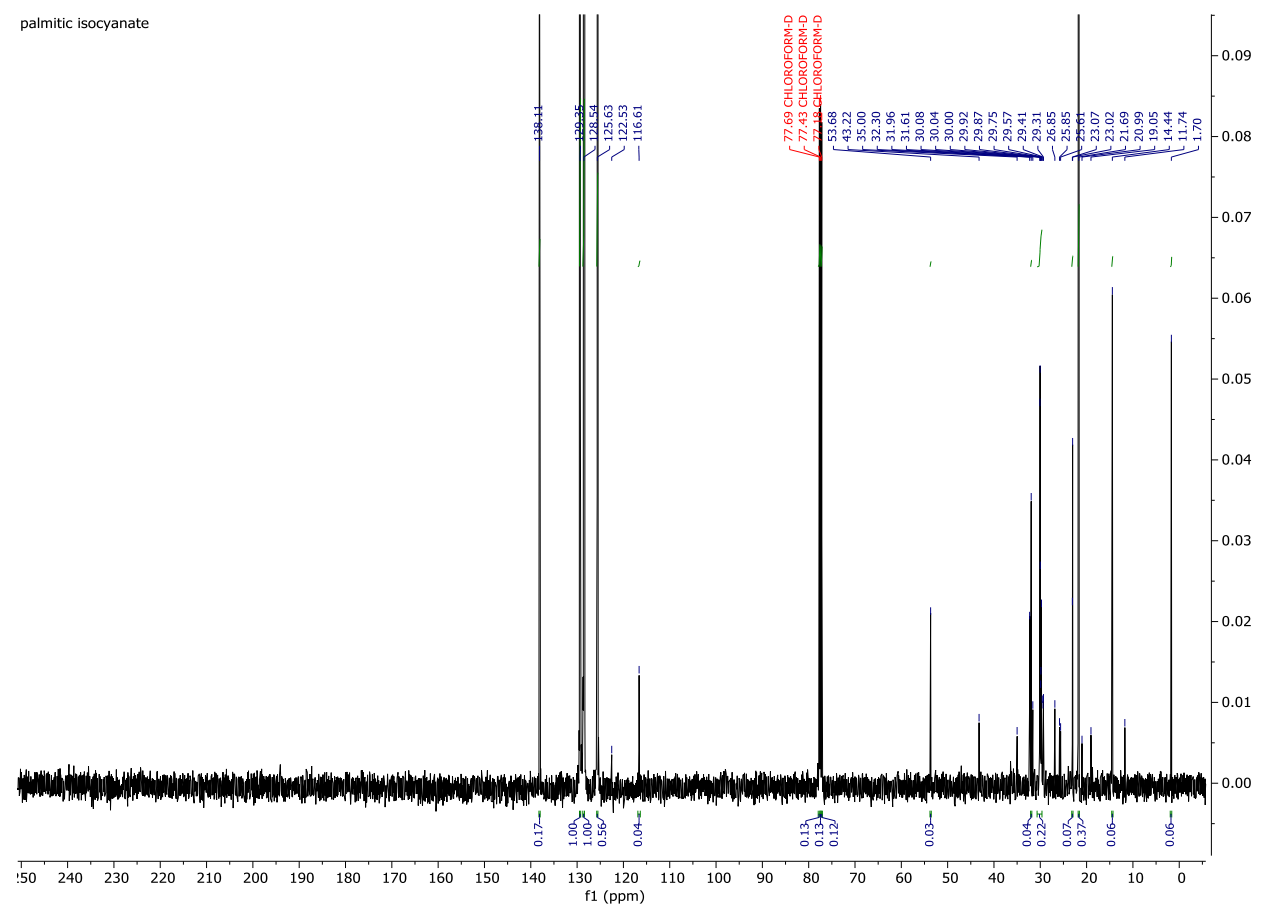

Figure S84: C NMR of hexadecyl isocyanate 


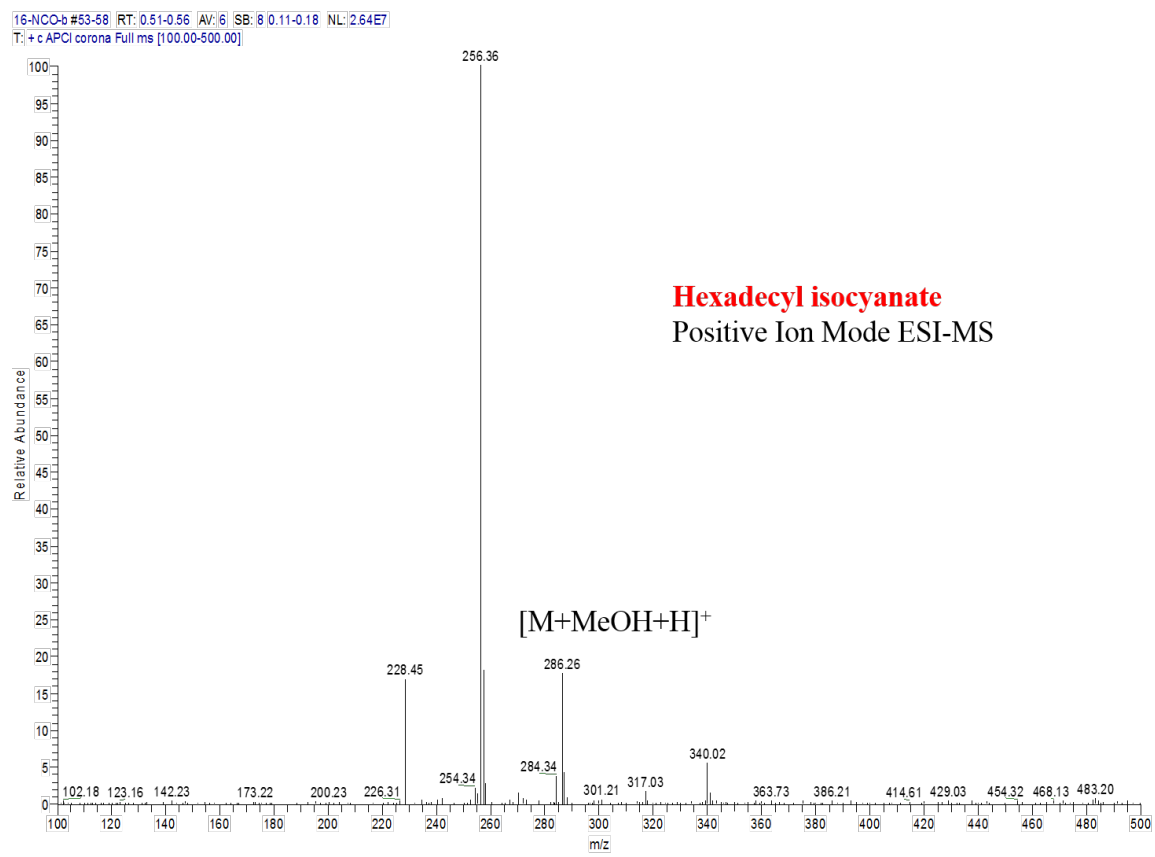

Figure S85: ESI MS of hexadecyl isocyanate

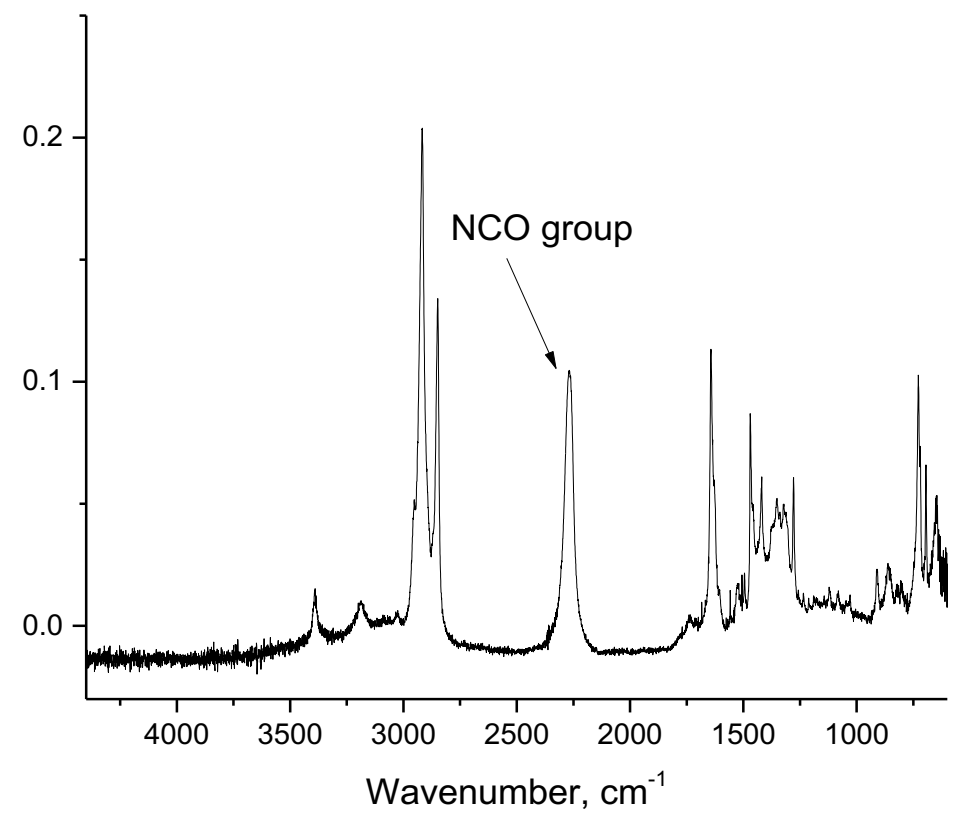

Figure S86: FT-IR of hexadecyl isocyanate 


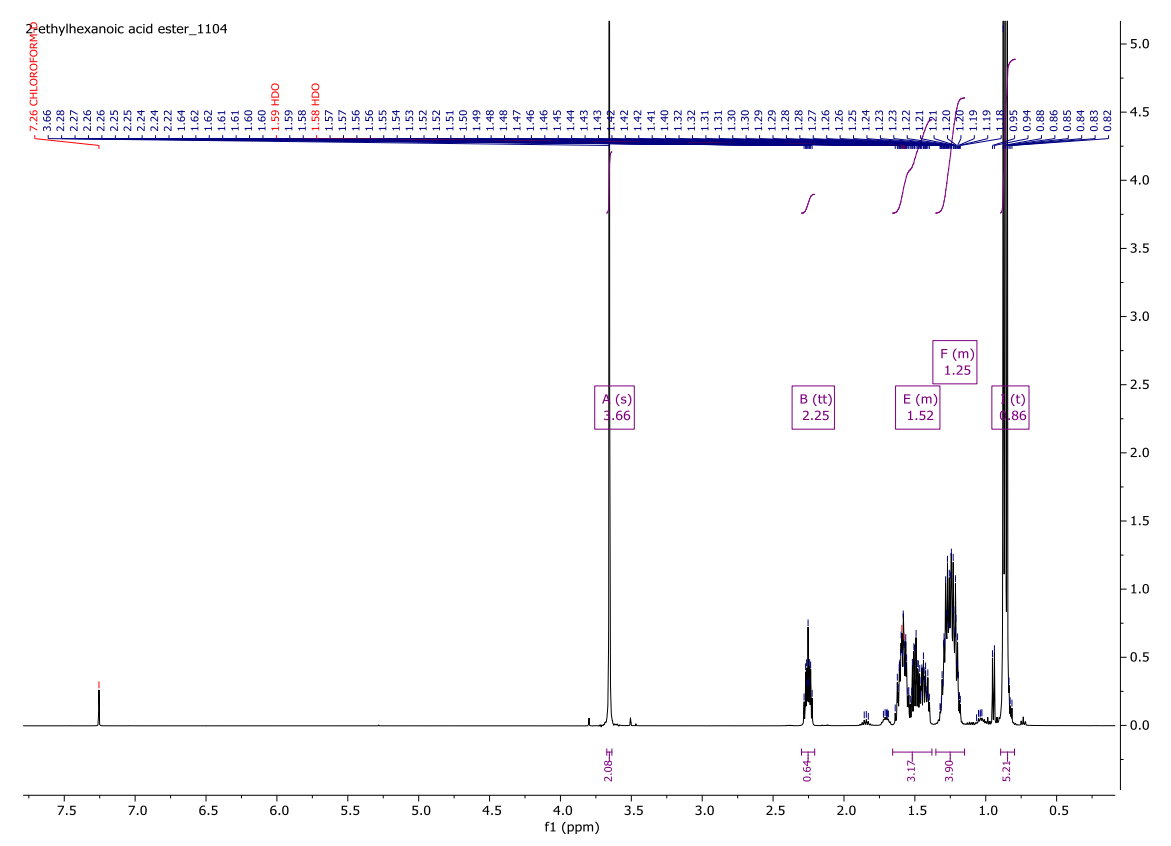

Figure S87. H NMR of 2-ethylhexanoic acid methyl ester

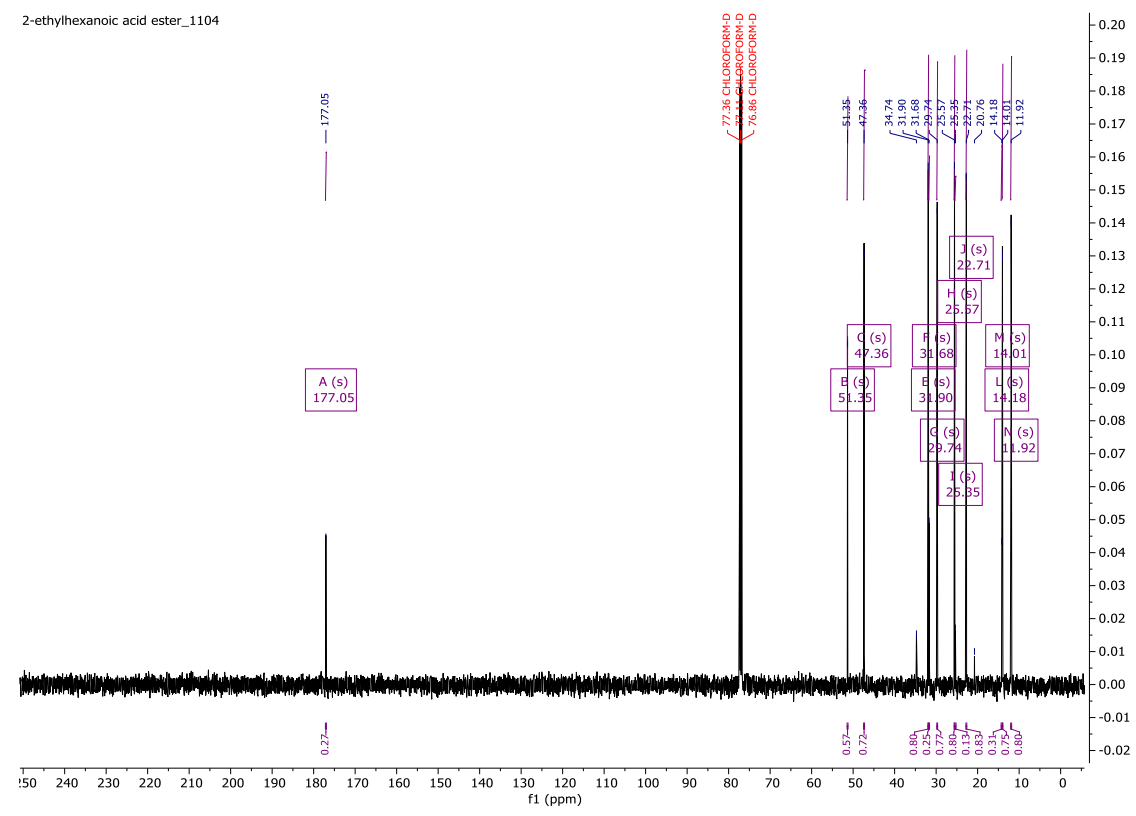

Figure S88. C NMR of 2-ethylhexanoic acid methyl ester 


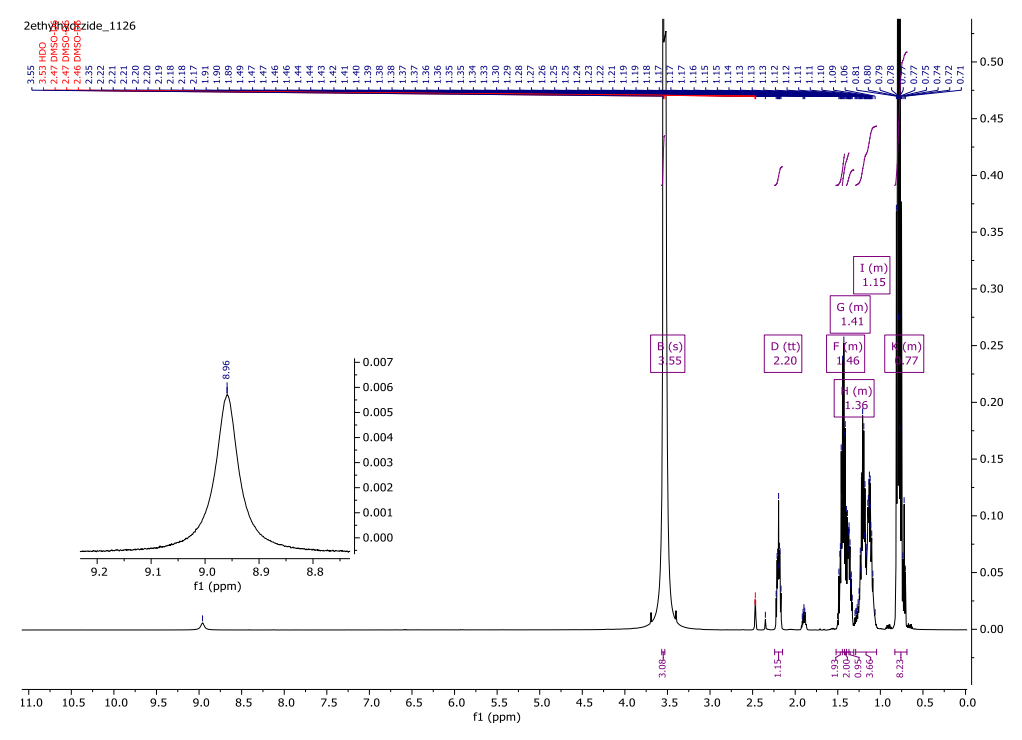

Figure S89: H NMR of 2-ethylhexanoic acid hydrazide

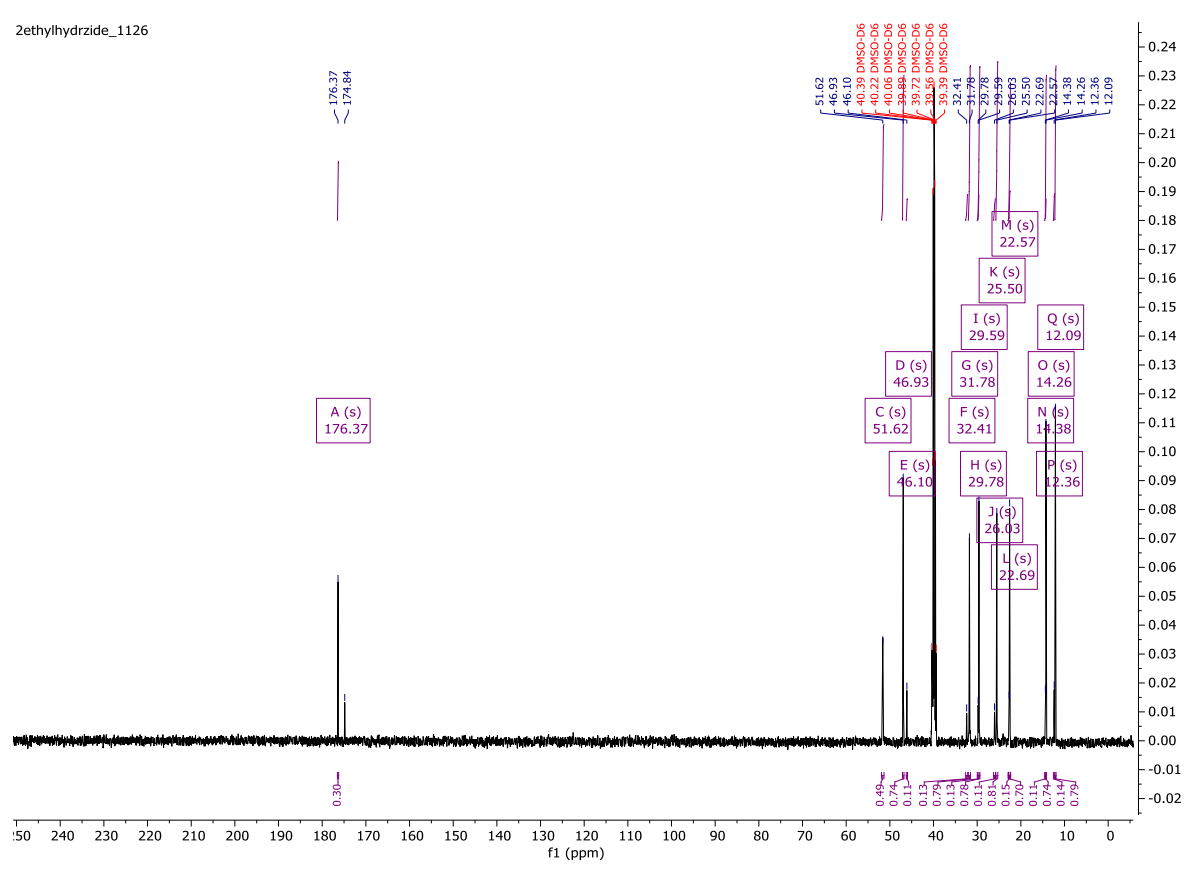

Figure S90: C NMR of 2-ethylhexanoic acid hydrazide 


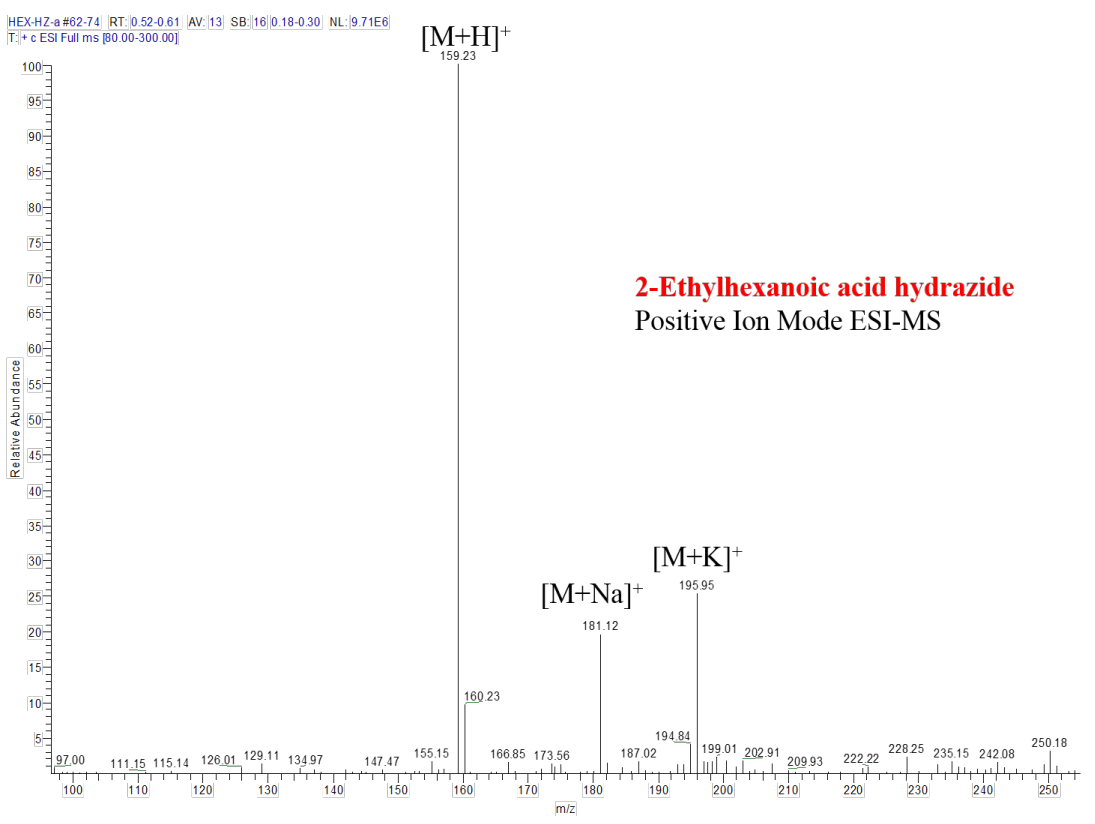

Figure S91: ESI MS of 2-ethylhexanoic acid hydrazide

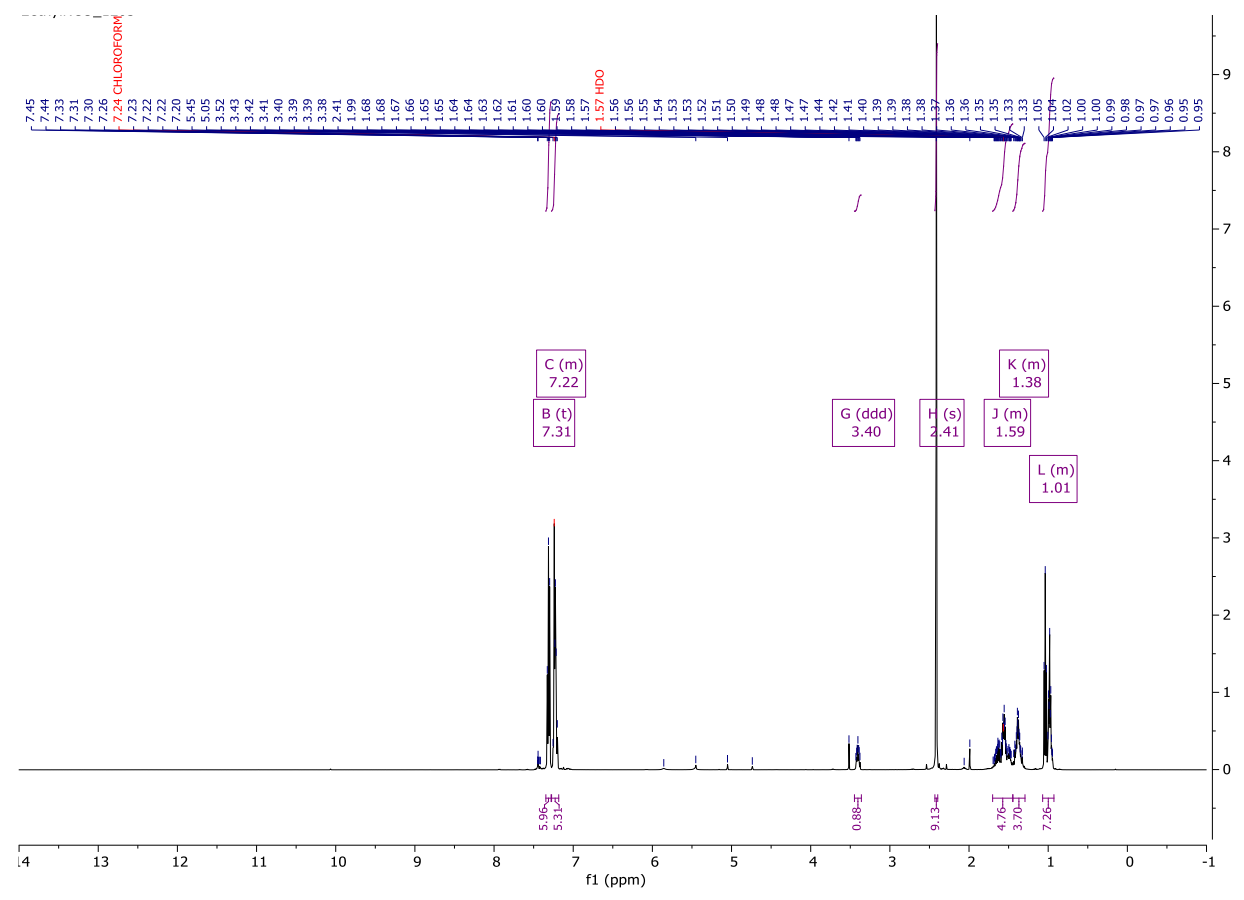

Figure S92: H NMR of 3-heptyl isocyanate 


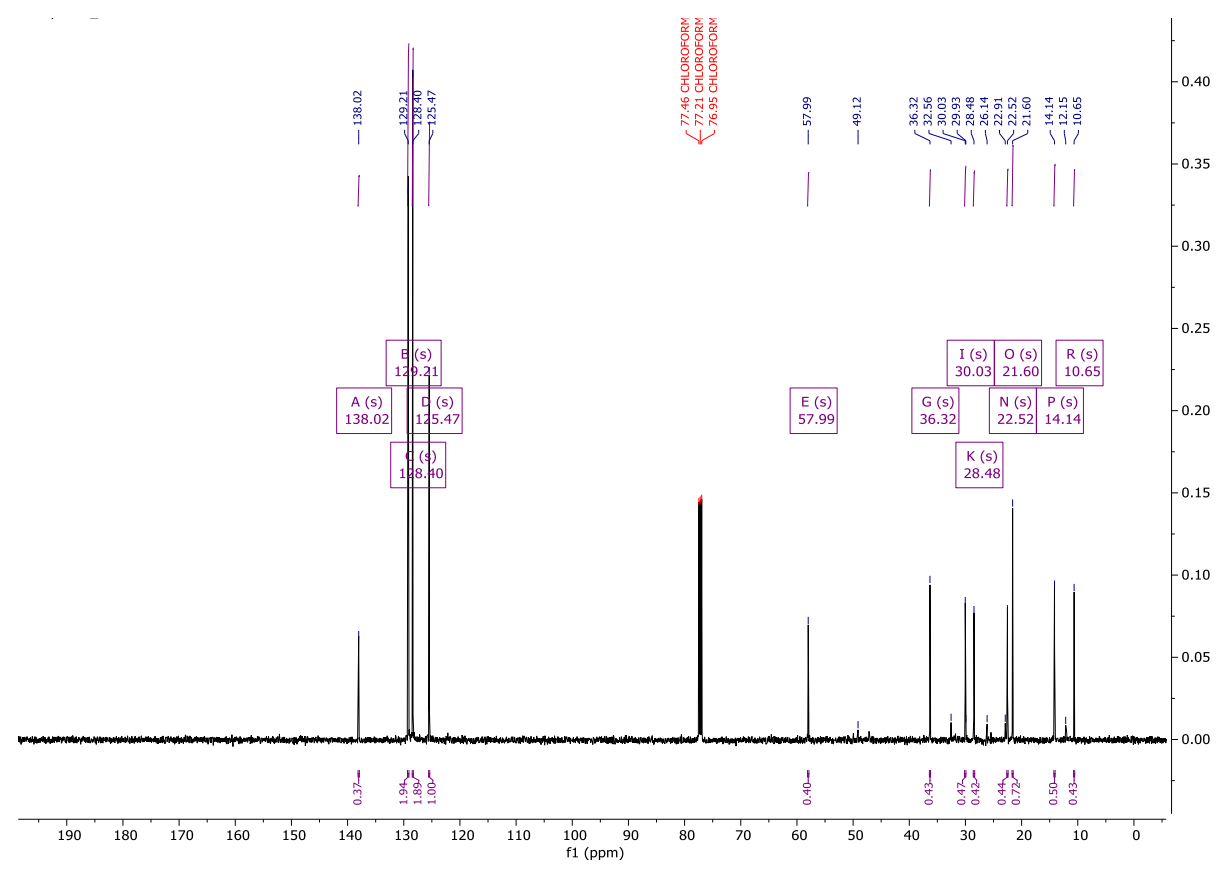

Figure S93: C NMR of 3-heptyl isocyanate

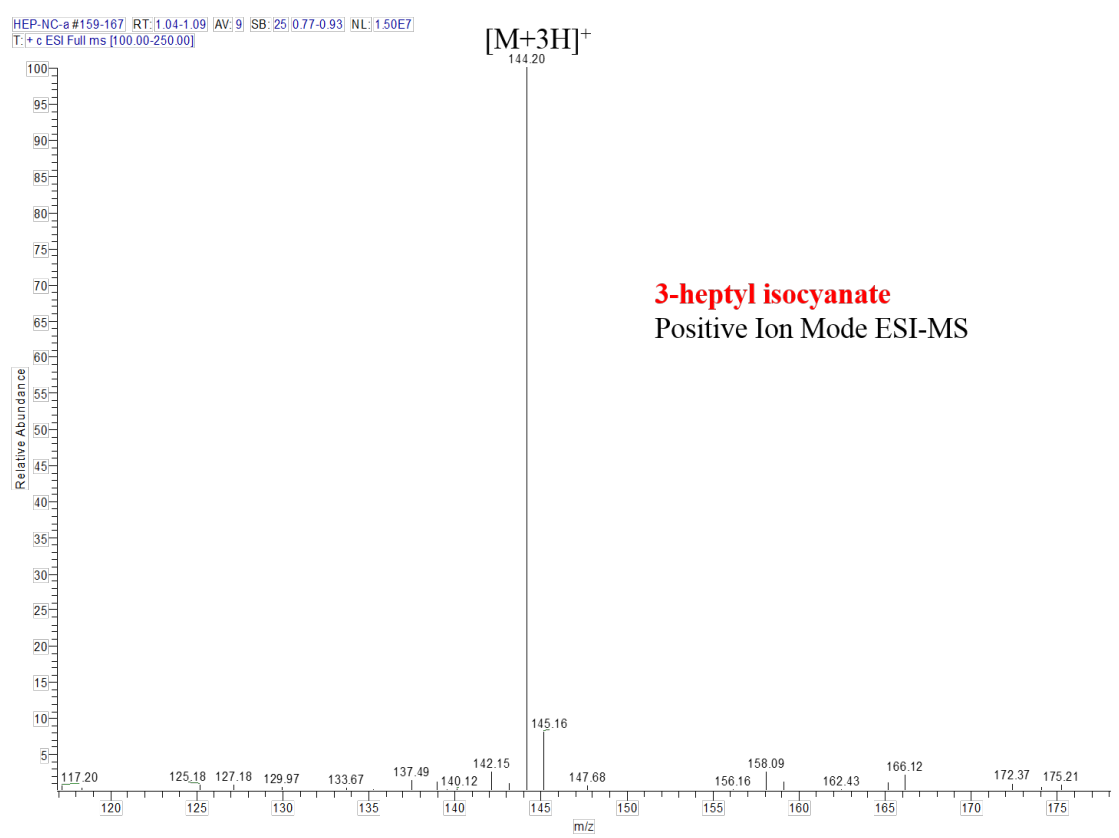

Figure S94: ESI MS of 3-heptyl isocyanate 


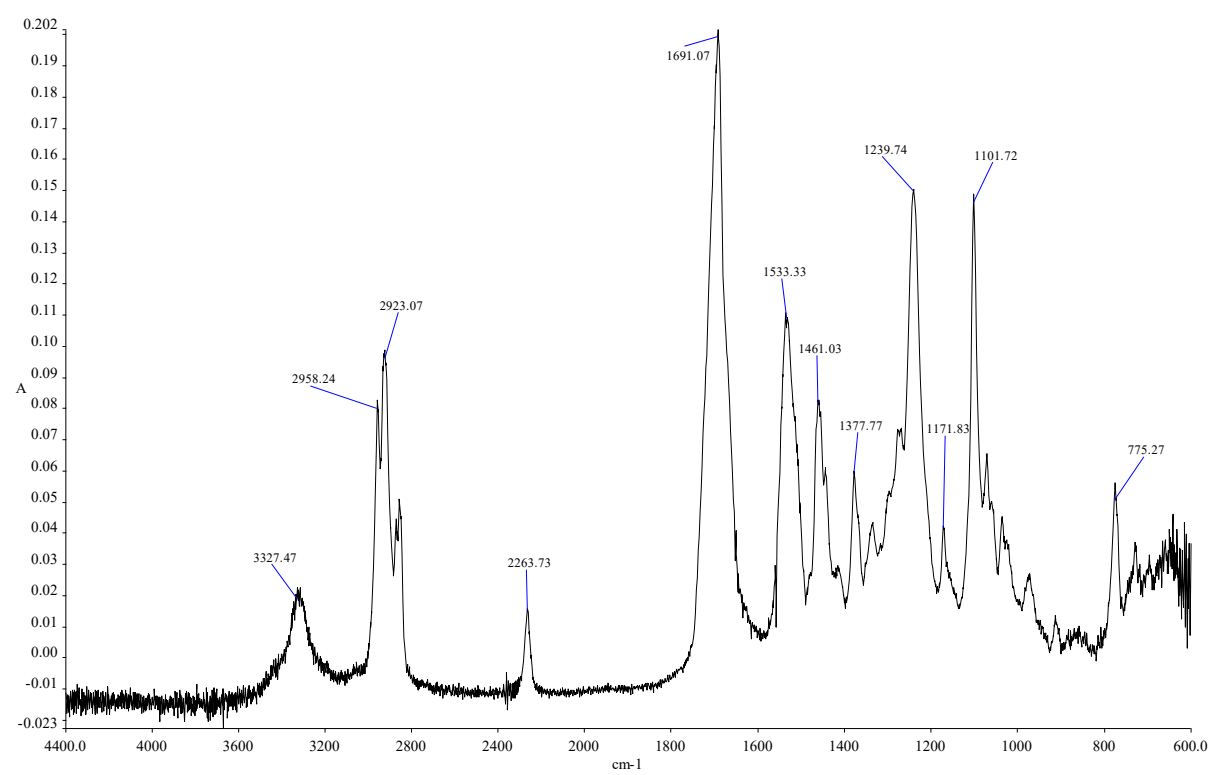

Figure S95: FT IR of 3-heptyl isocyanate

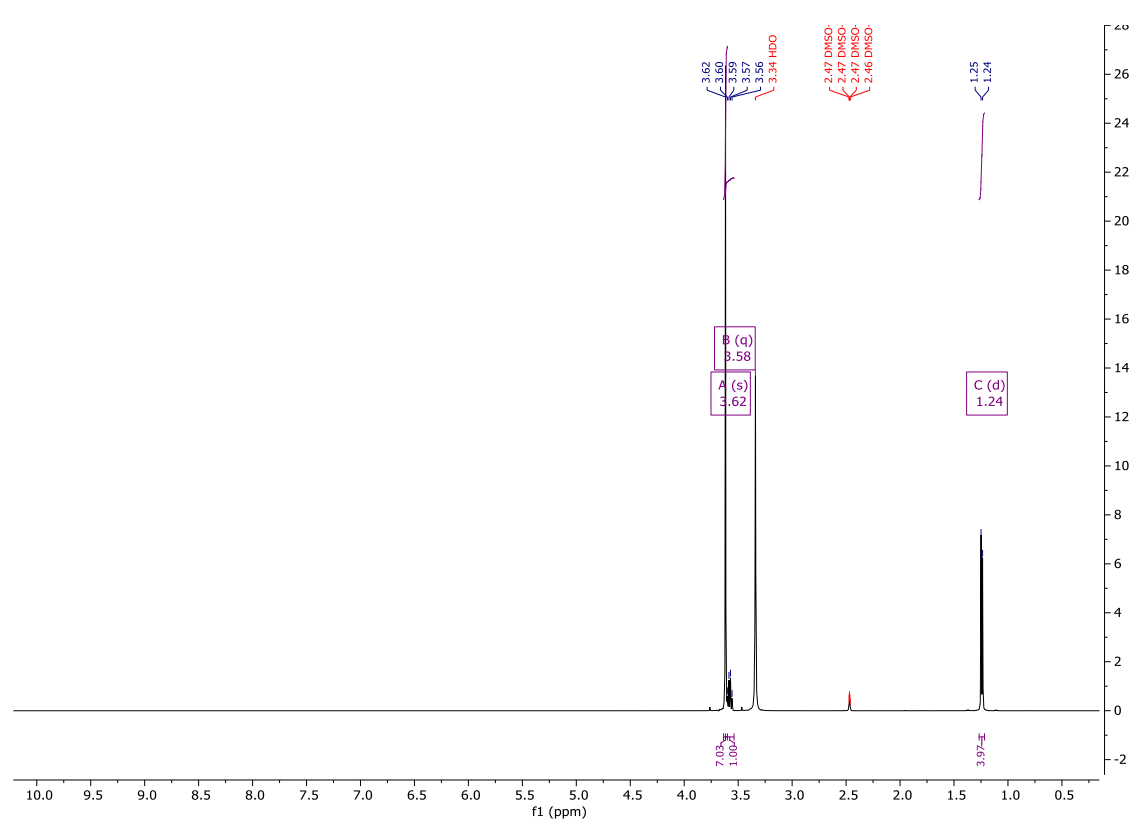

Figure S96: H NMR of dimethyl methylmalonate 


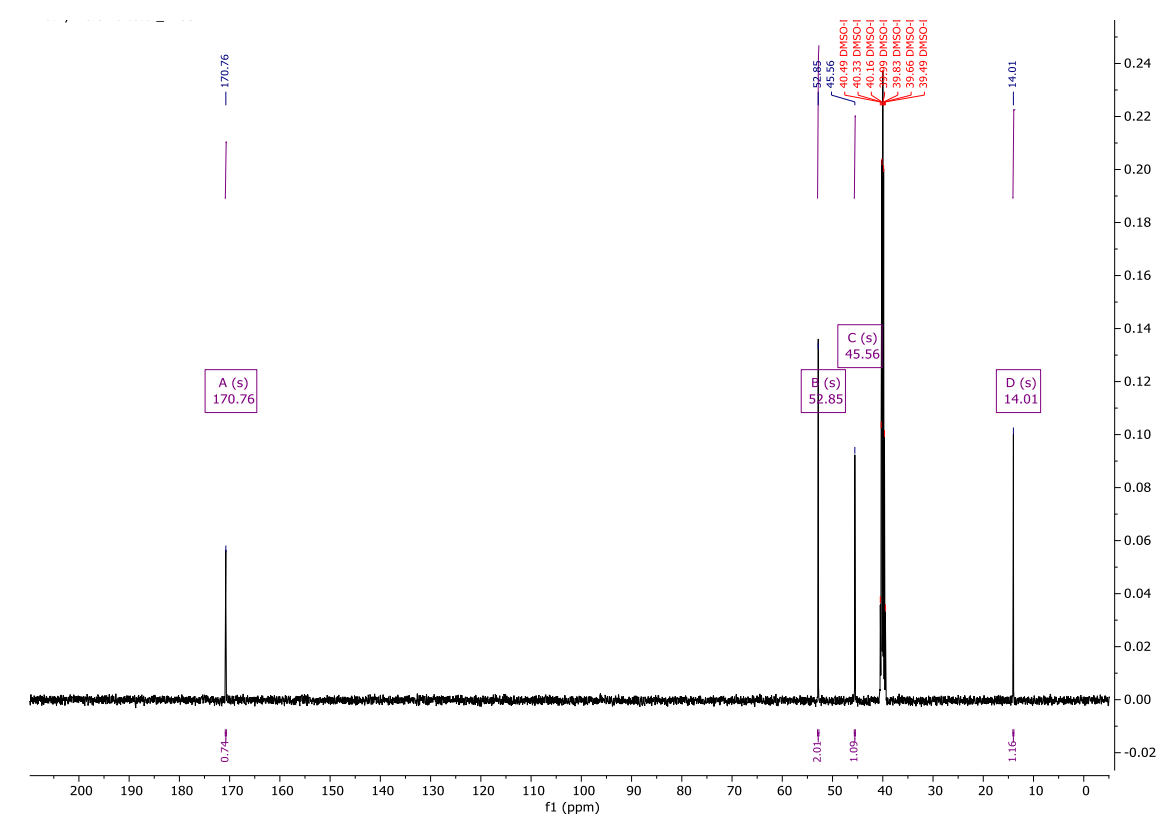

Figure S97: C NMR of dimethyl methylmalonate

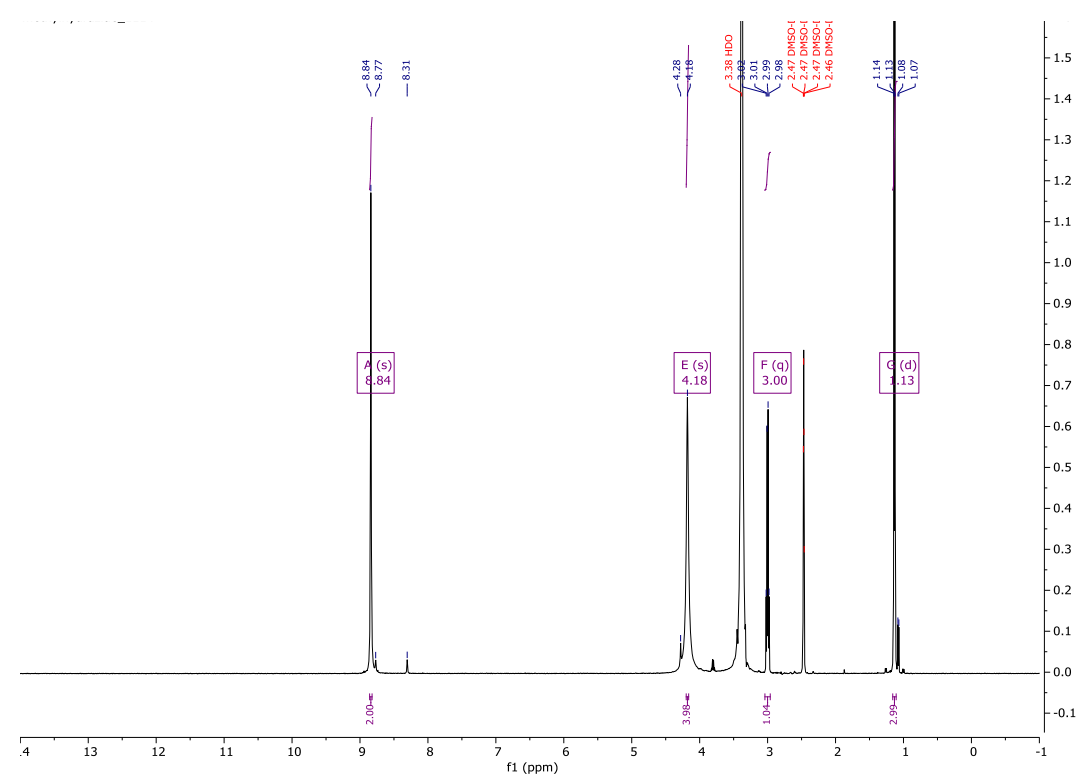

Figure S98. H NMR of malonic acid dihydrazide 


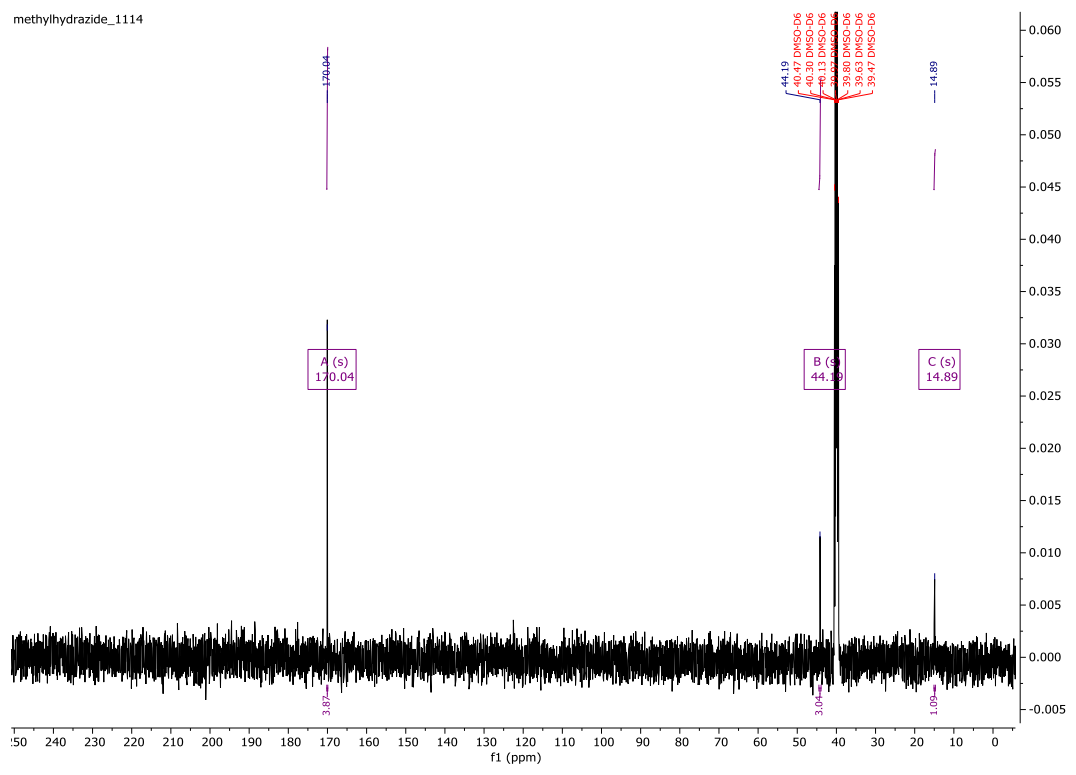

Figure S99: C NMR of malonic acid dihydrazide

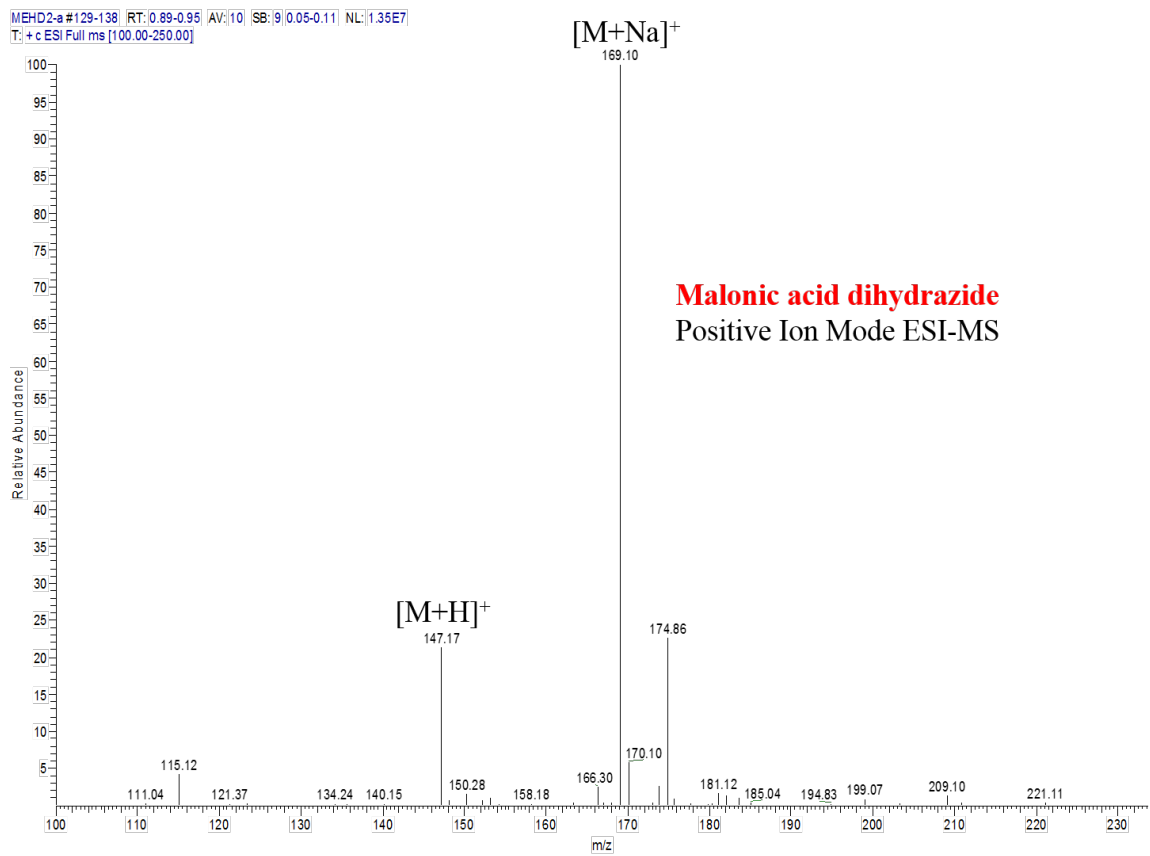

Figure S100: ESI MS of malonic acid hydrazide 


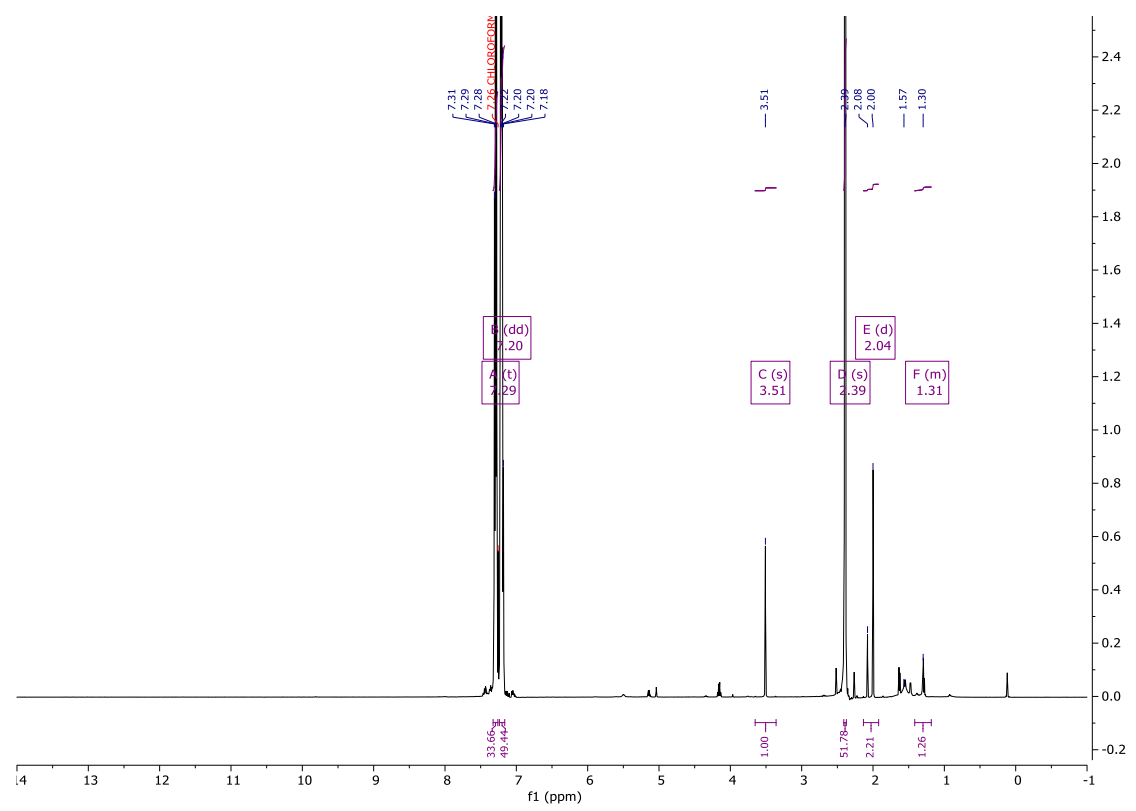

Figure S101: H NMR of ethylidene diisocyanate

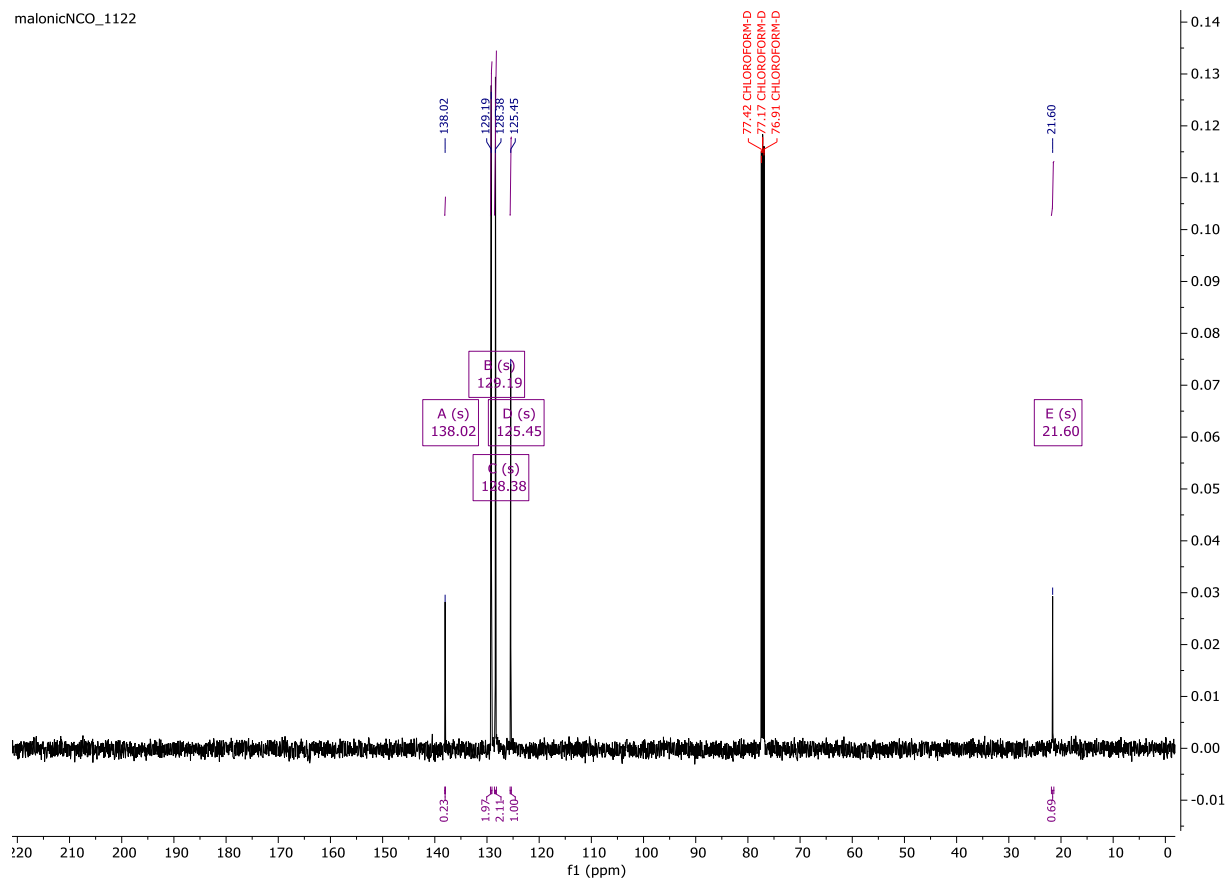

Figure S102: C NMR of ethylidene diisocyanate 


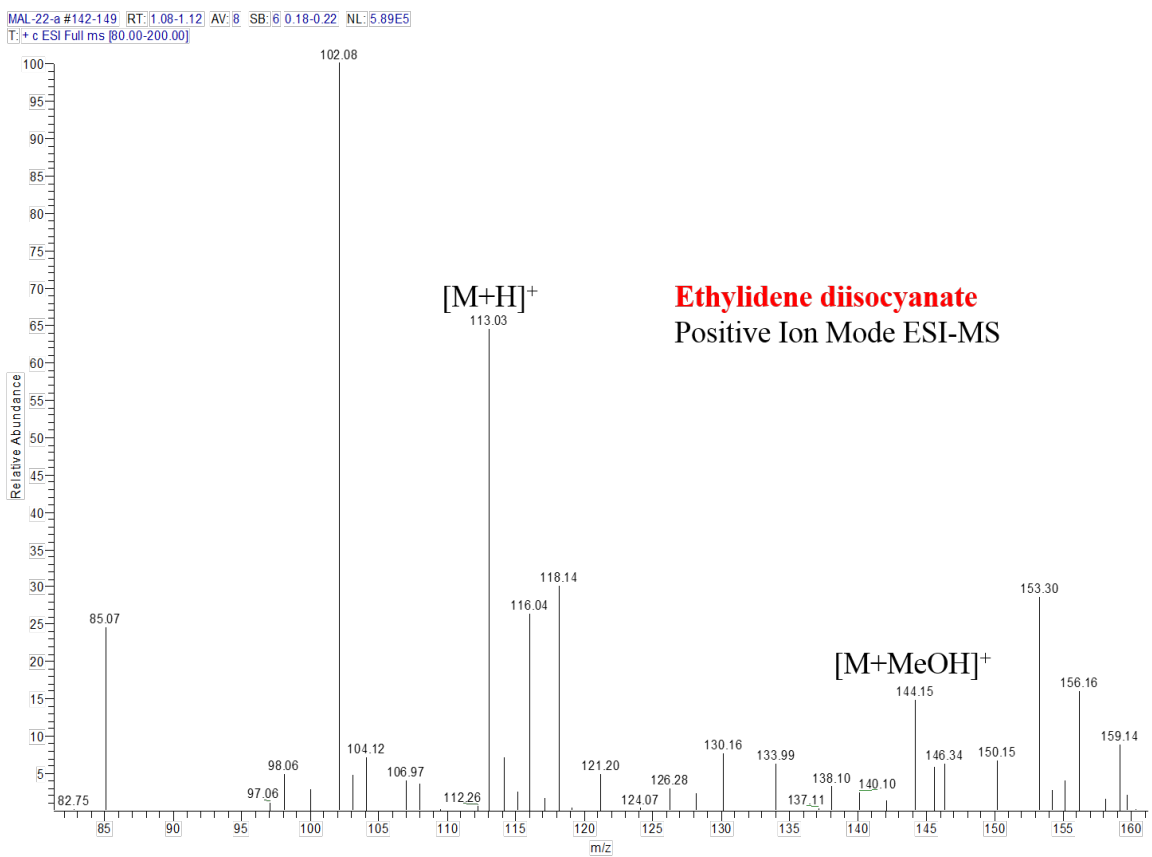

Figure S103: ESI MS of ethylidene diisocyanate

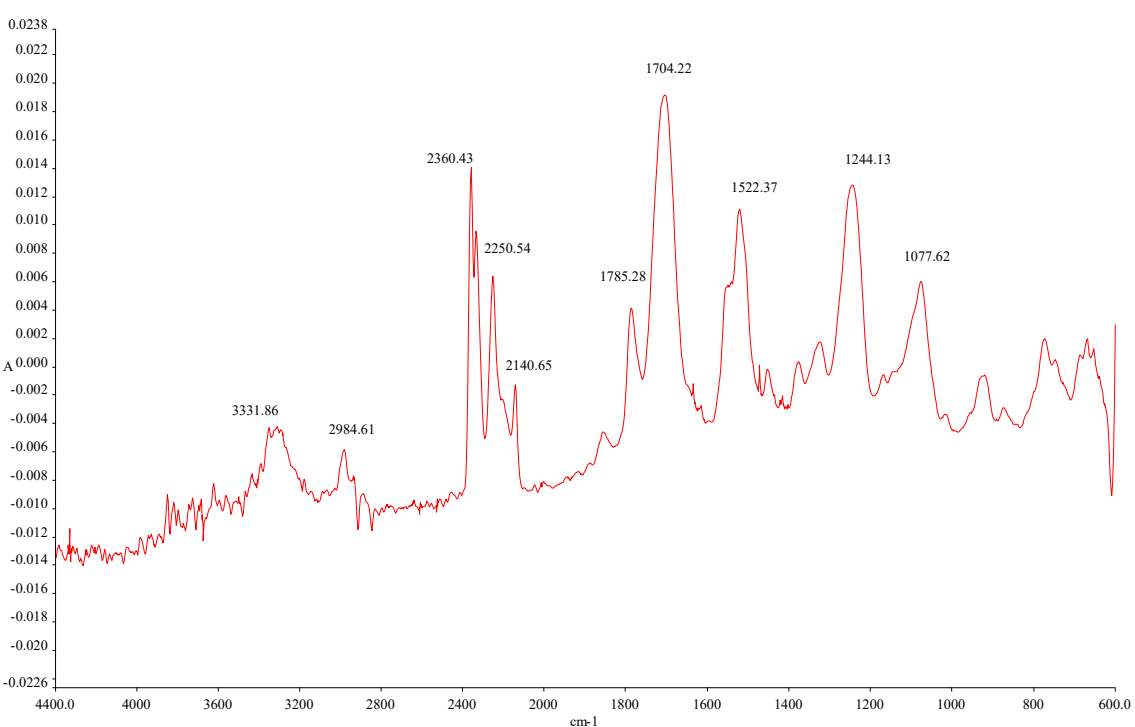

Figure S104: FT IR of ethylidene diisocyanate 


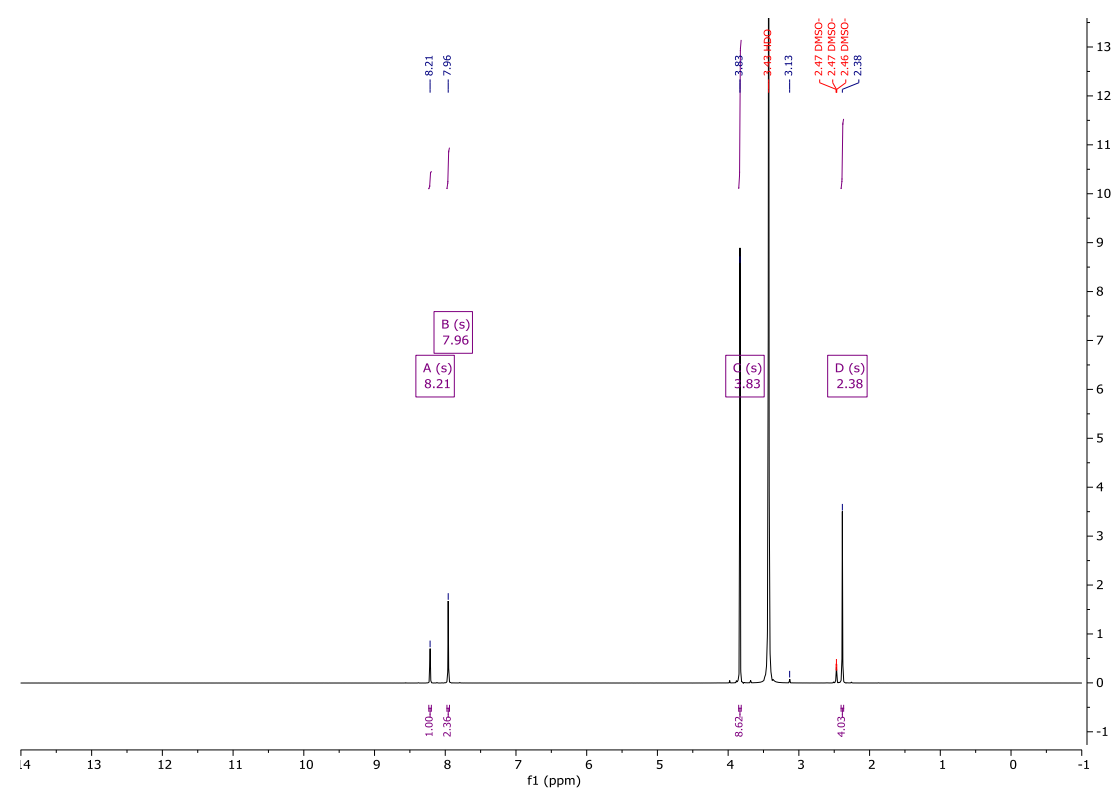

Figure S105: H NMR of 5-methylisophthalic acid dimethyl ester

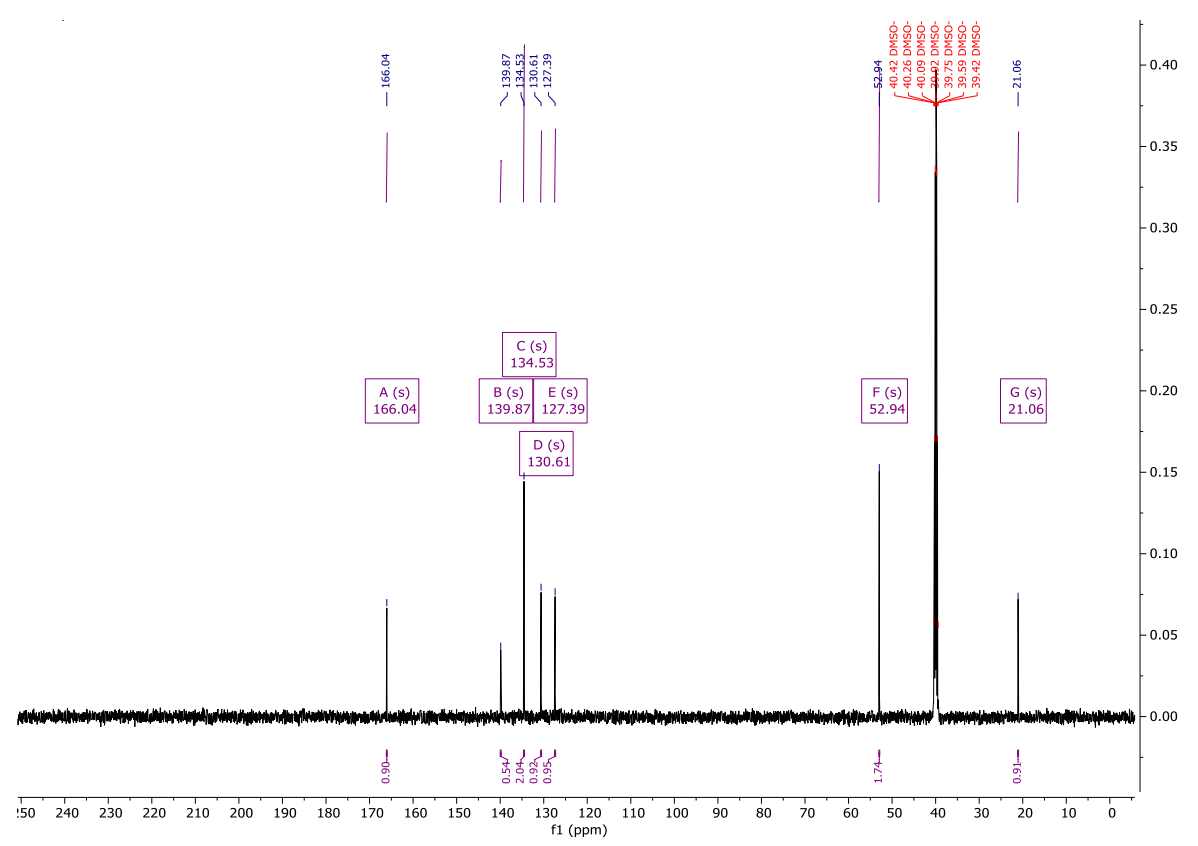

Figure S106: C NMR of 5-methylisophthalic acid dimethyl ester 


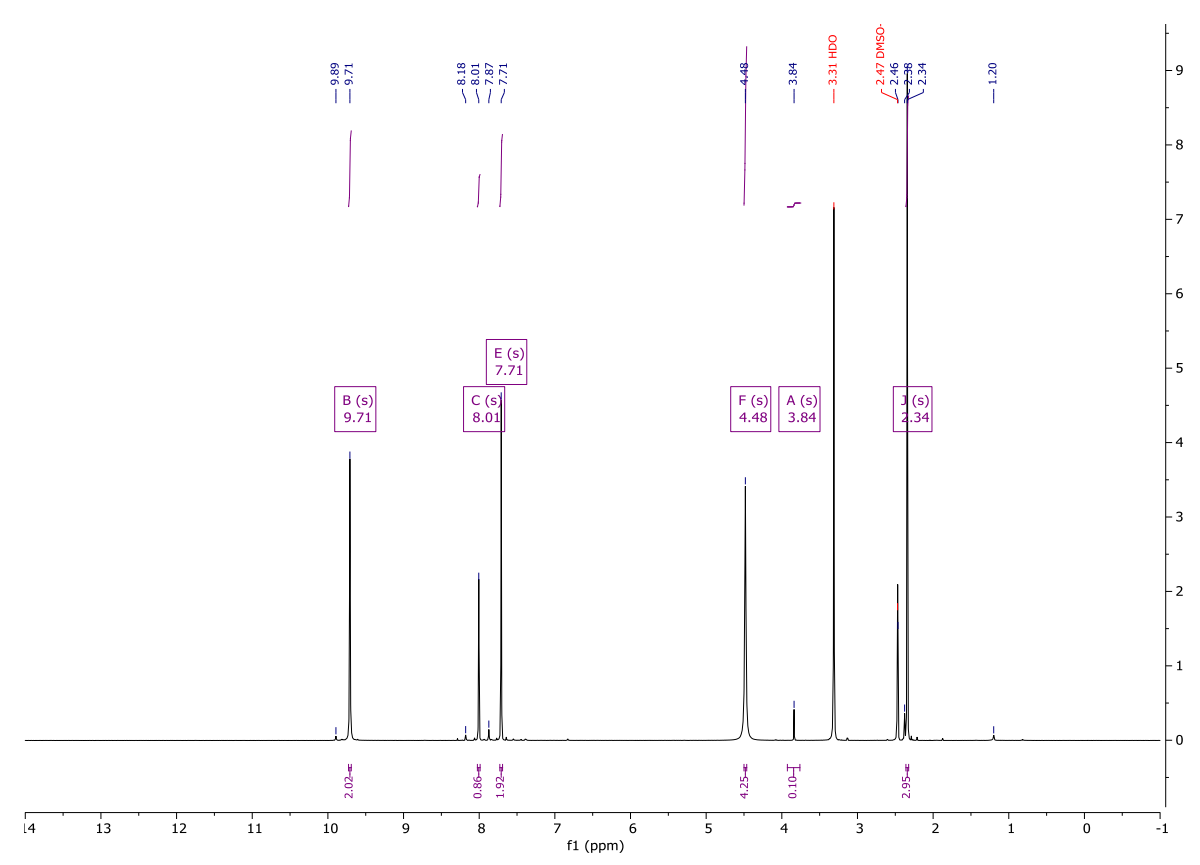

Figure S107: H NMR of 1,3-benzenedicarboxylic acid, 5-methyl-1,3, dihydrazide

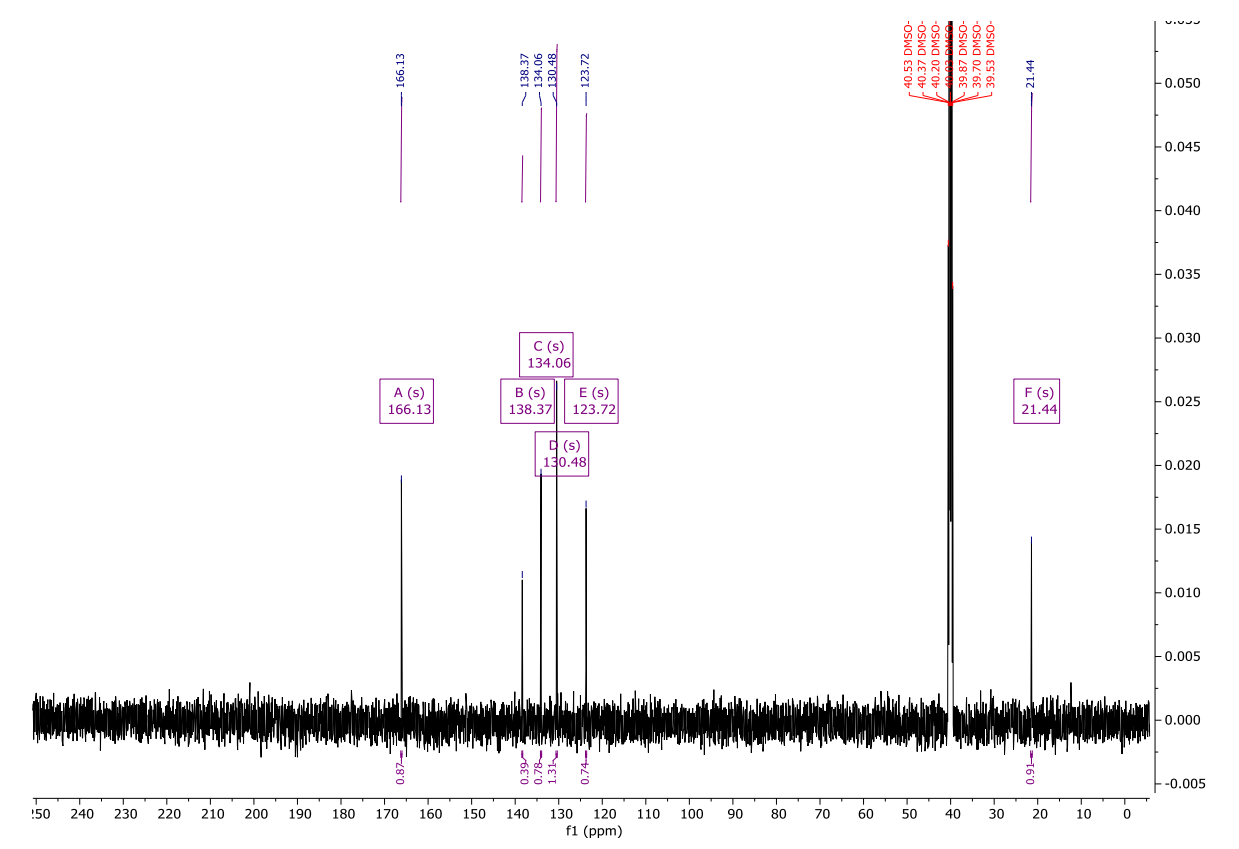

Figure S108: C NMR of 1,3-benzenedicarboxylic acid, 5-methyl-1,3, dihydrazide 


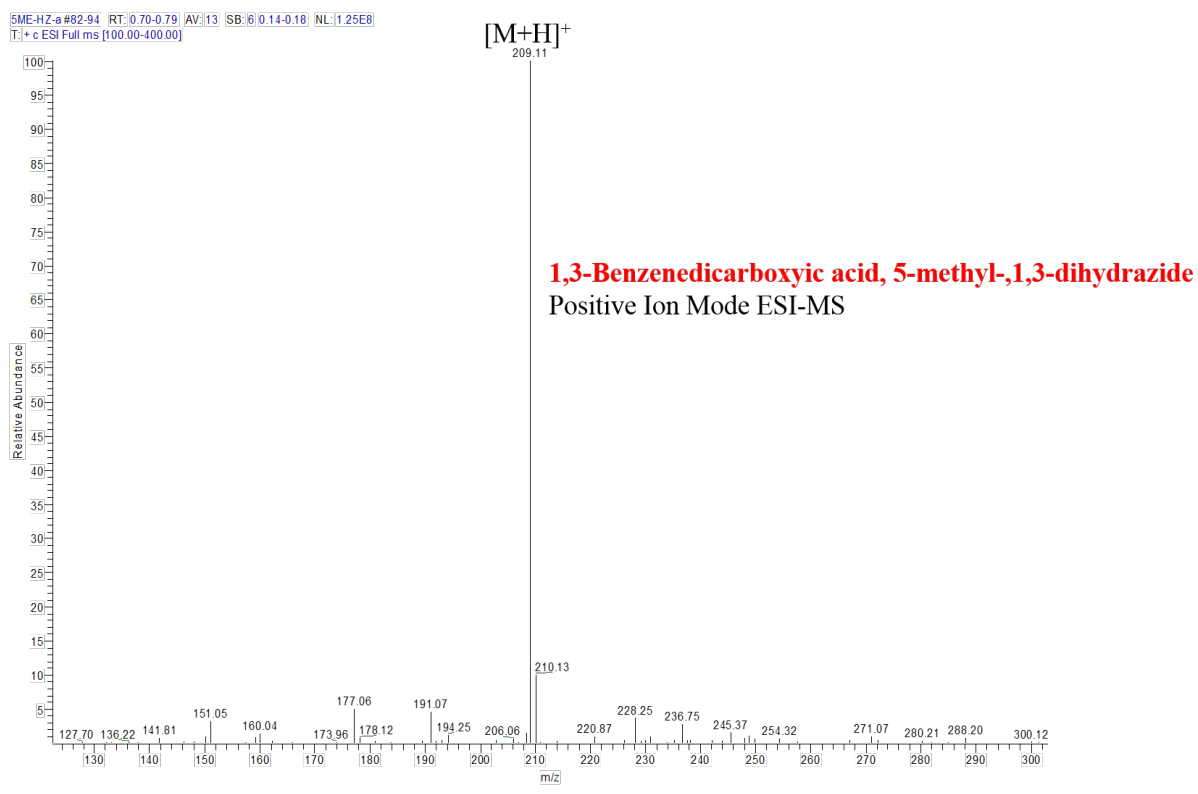

Figure S109: ESI MS of 1,3-benzenedicarboxylic acid, 5-methyl-1,3,dihydrazide

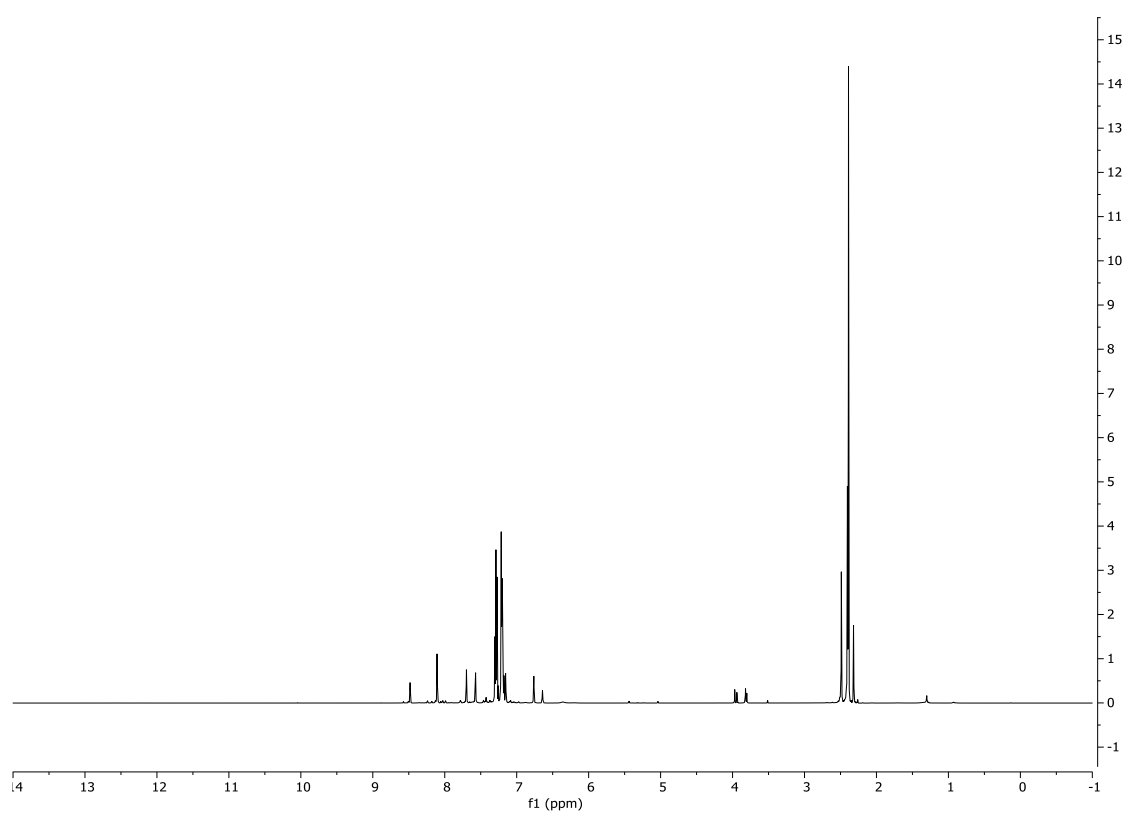

Figure S110: H NMR of 1,3-Diisocyanato-5-methylbenzene 


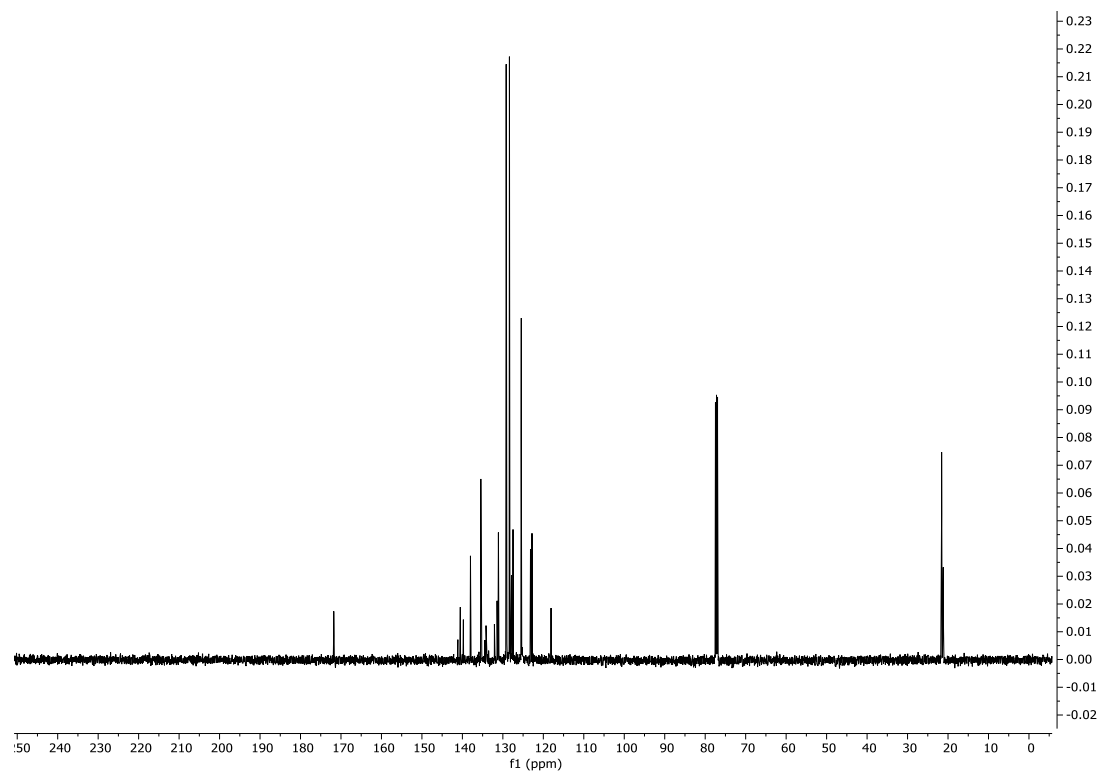

Figure S111: C NMR of 1,3-Diisocyanato-5-methylbenzene

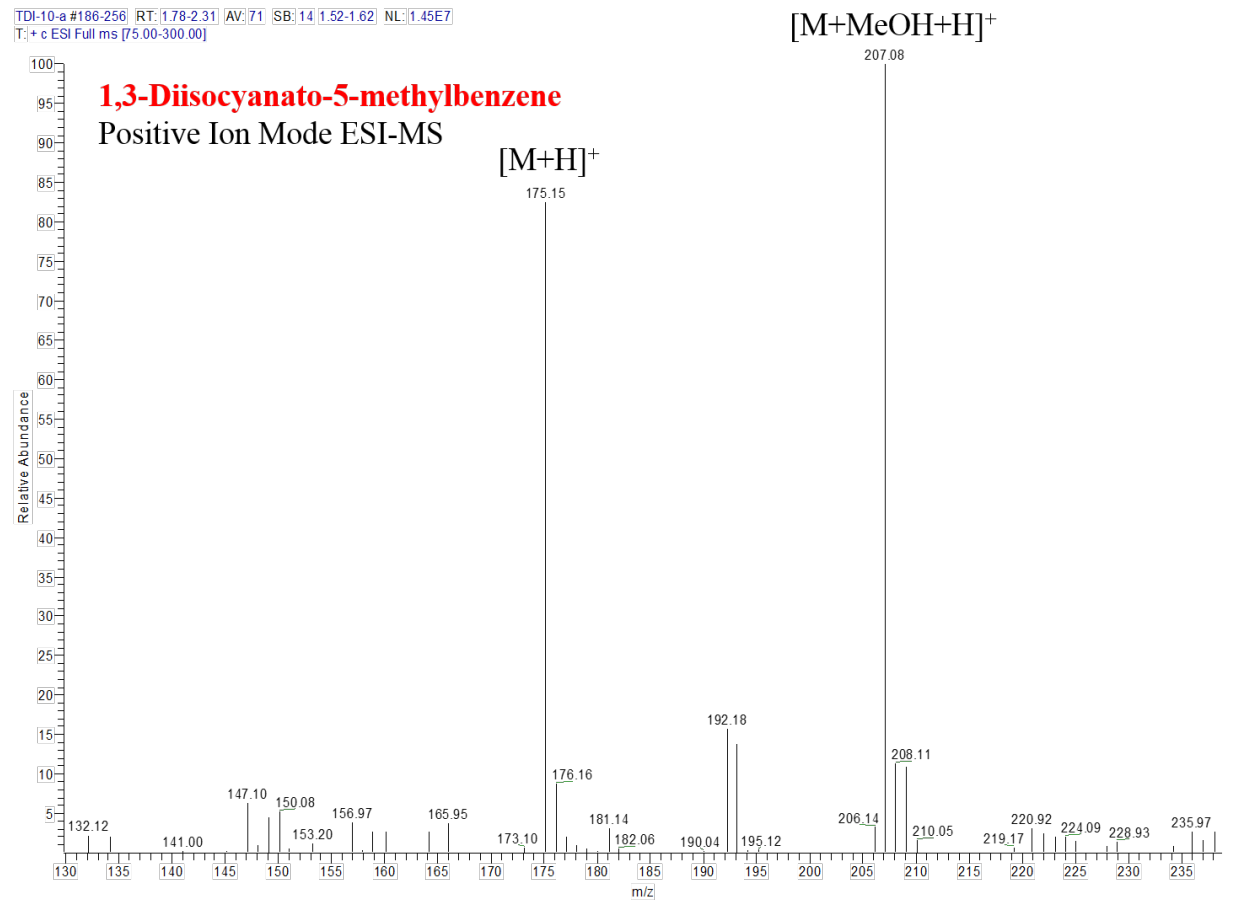

Figure S112: ESI MS of 1,3-diisocyanato-5-methylbenzene 


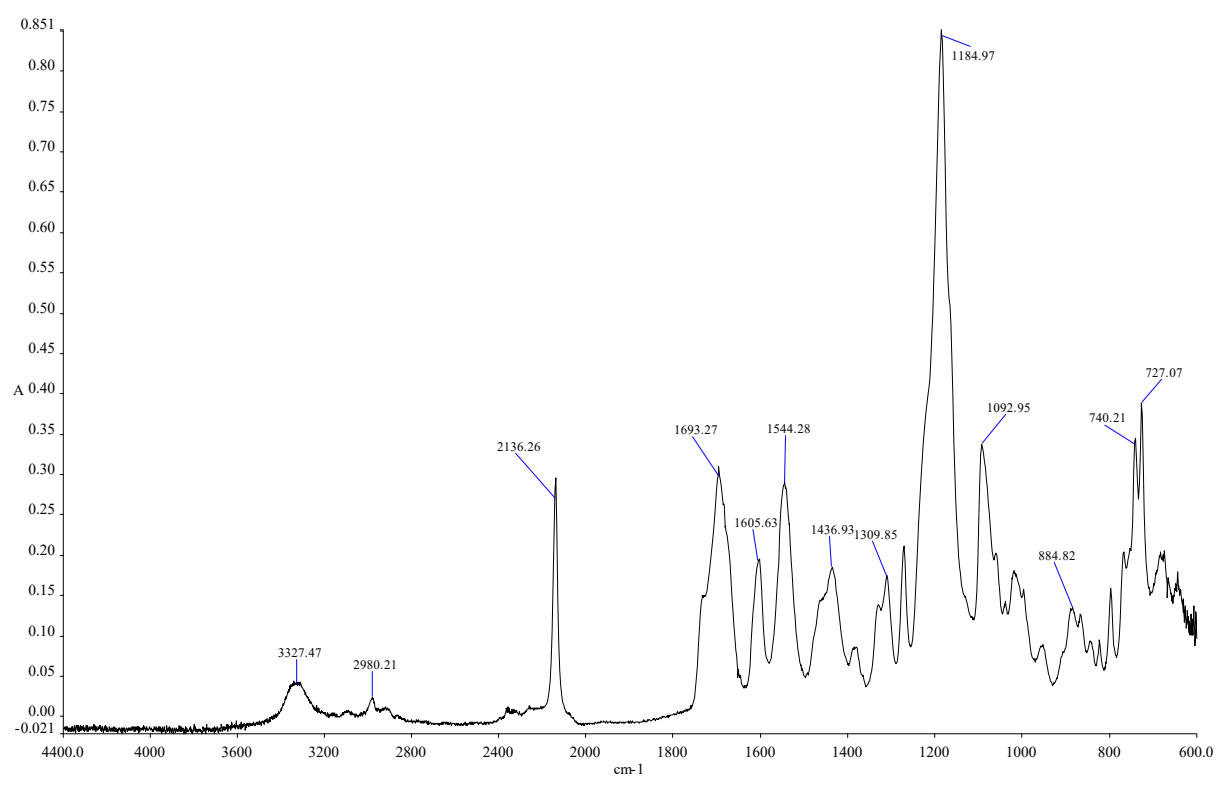

Figure S113: FT-IR of 1,3-diisocyanato-5-methylbenzene

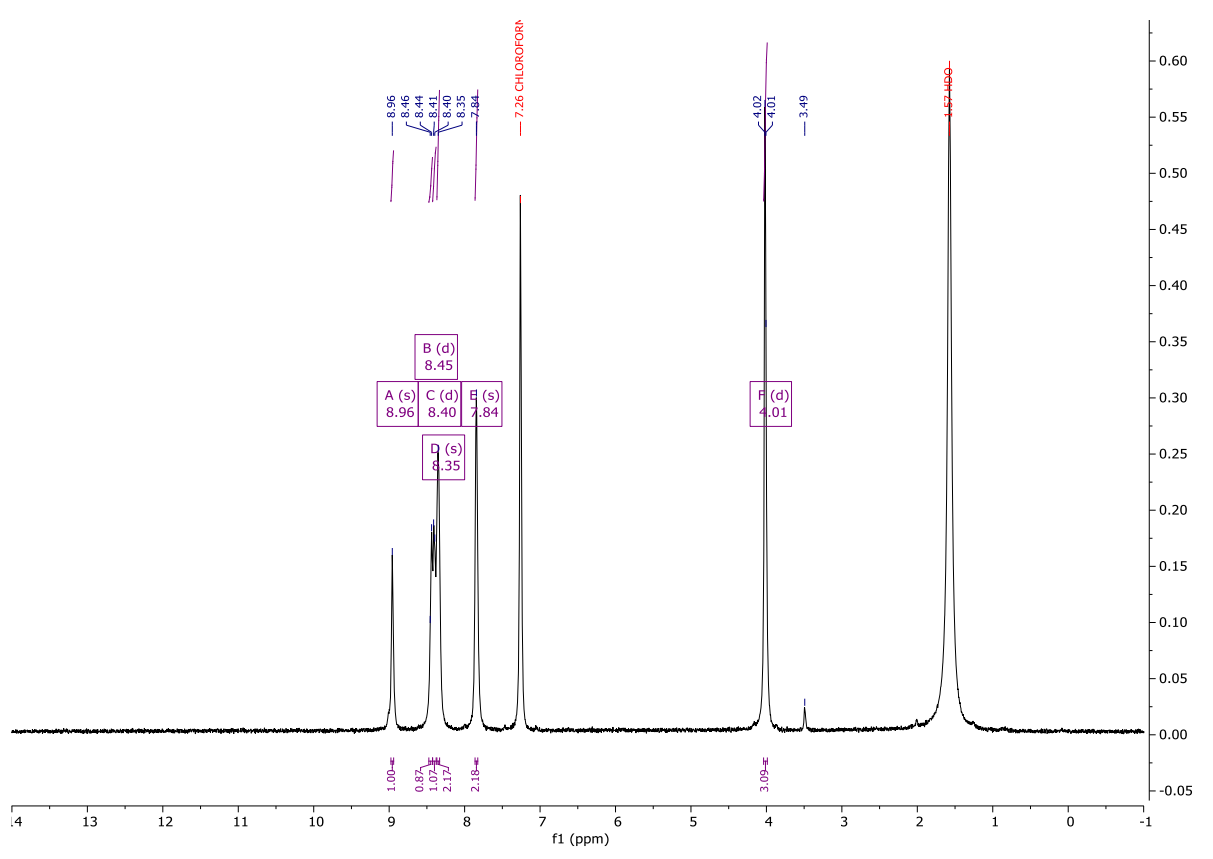

Figure S114: H NMR of 2-Methylcarboxyanthraquinone 


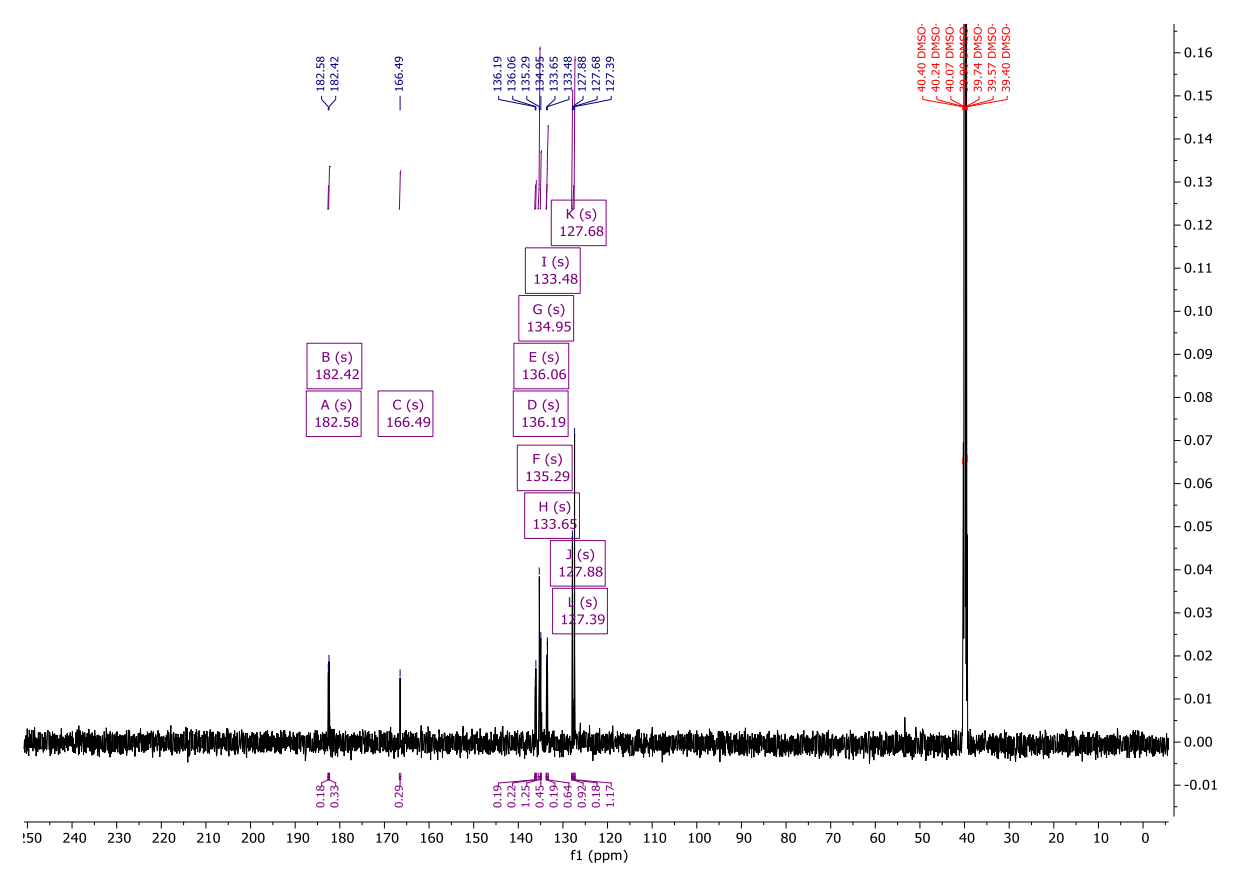

Figure S115: C NMR of 2-Methylcarboxyanthraquinone

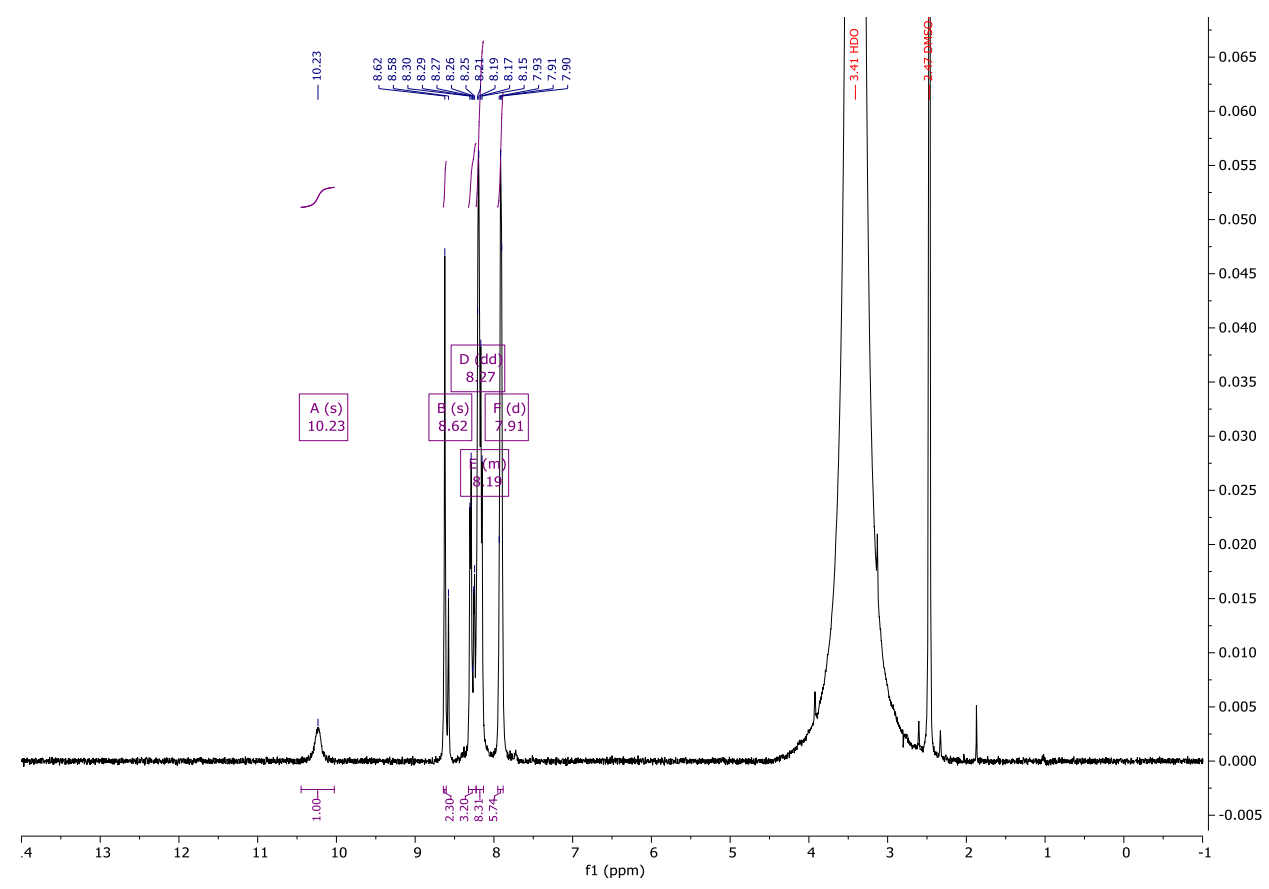

Figure S116: H NMR of 2-Anthraquinonecarboxylic acid hydrazide 


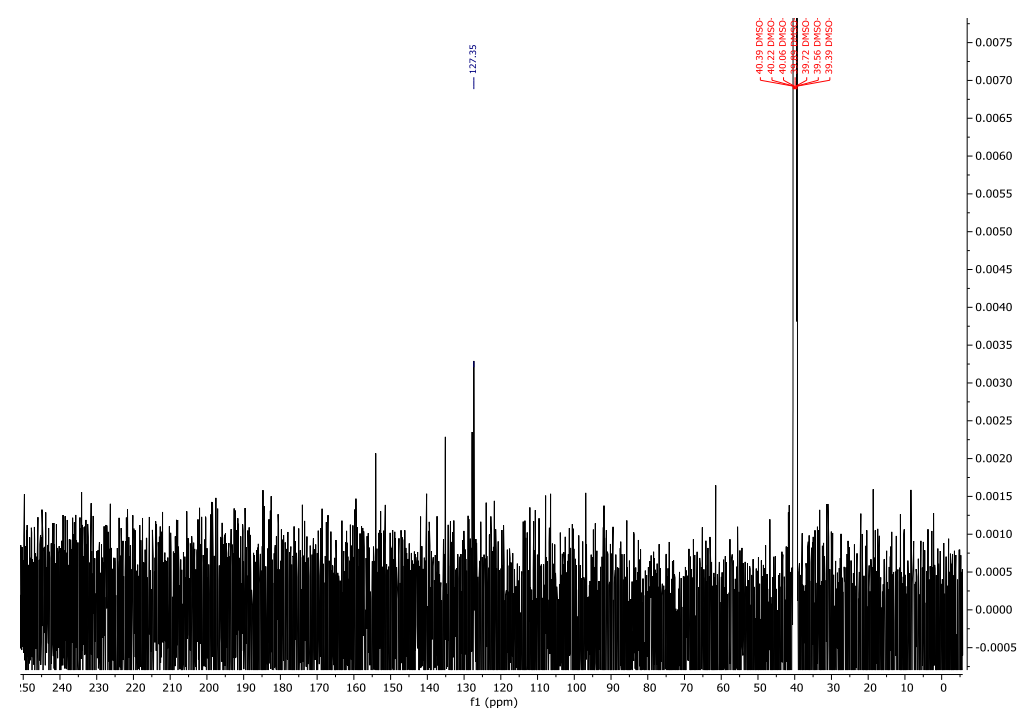

Figure S117: C NMR of 2-Anthraquinonecarboxylic acid hydrazide

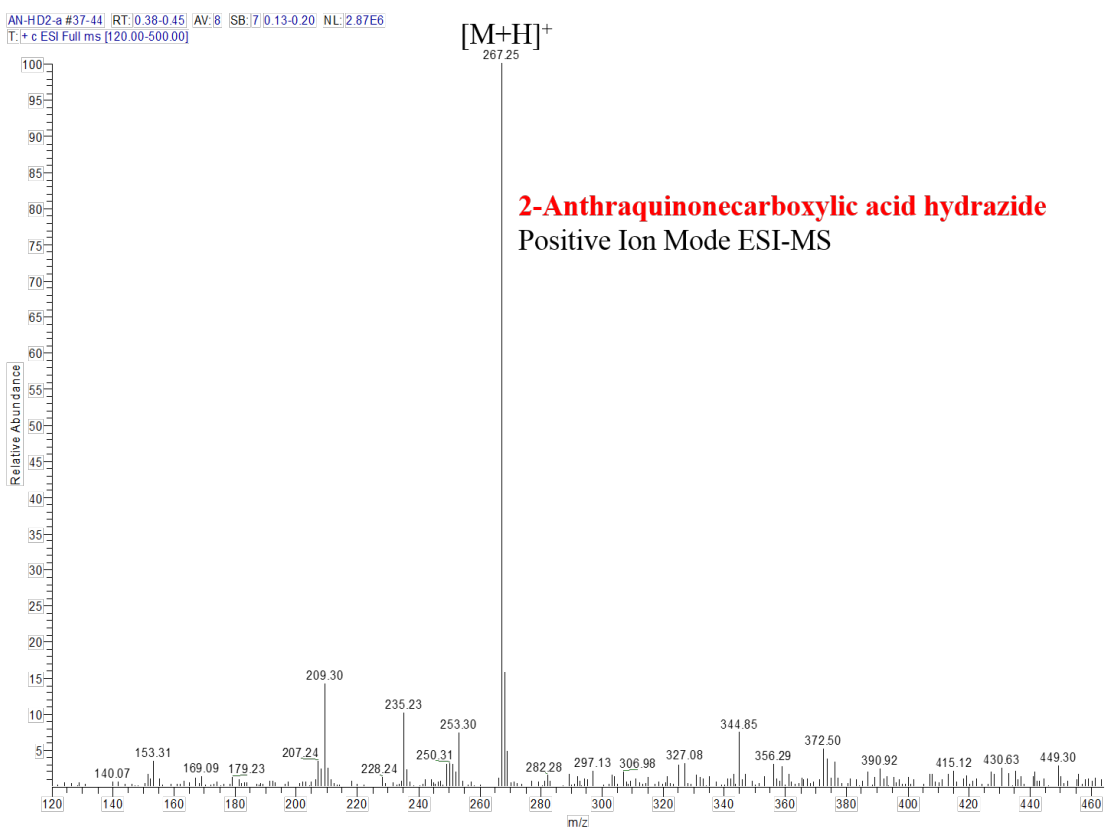

Figure S118: ESI MS of 2-Anthraquinonecarboxylic acid hydrazide 


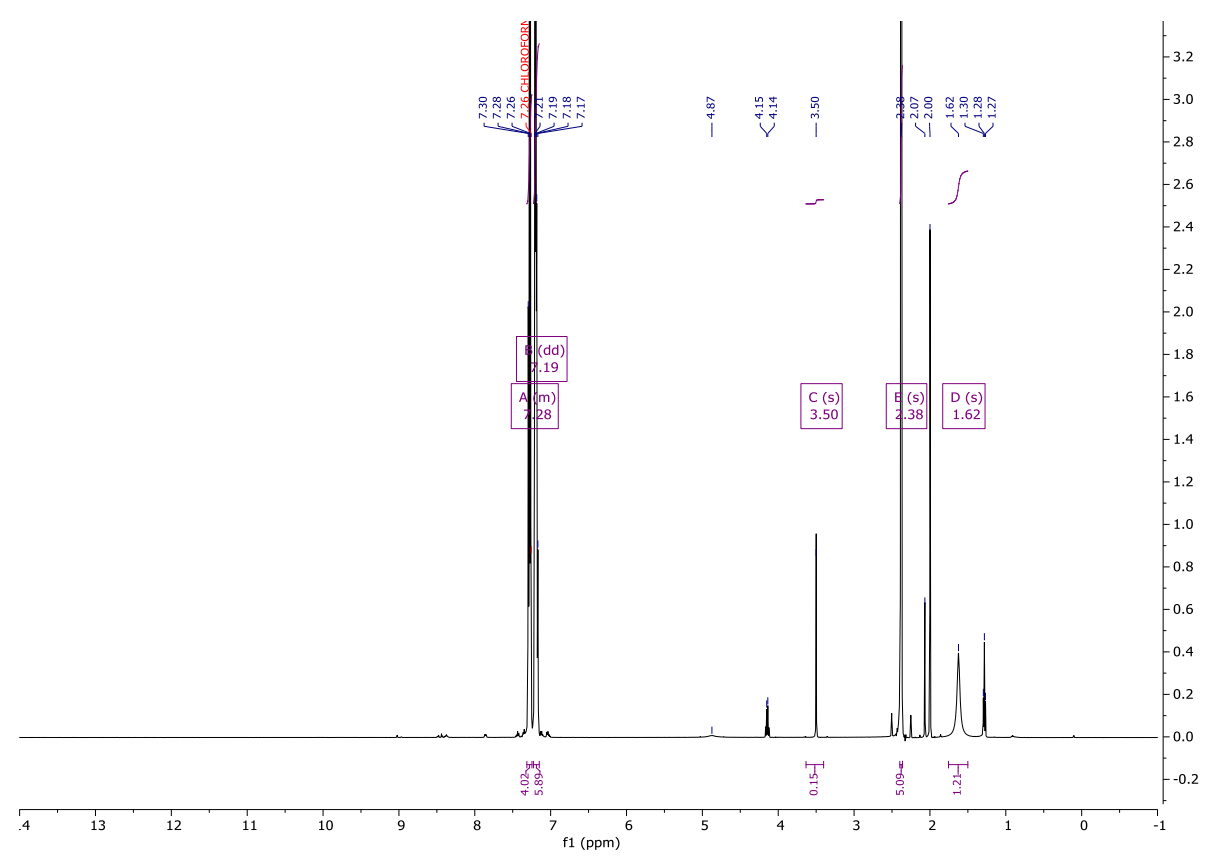

Figure S119: H NMR of 2-Isocyanato-9,10-anthracenedione

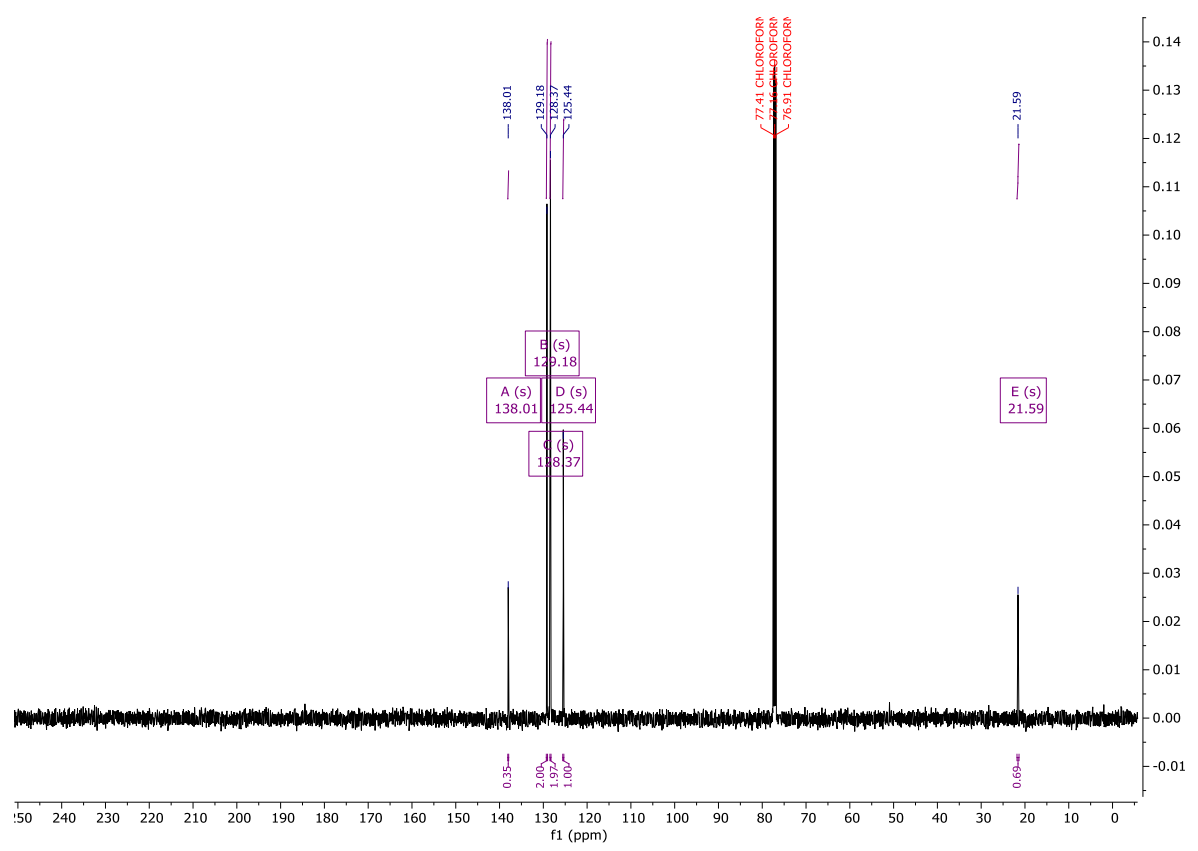

Figure S120: C NMR of 2-Isocyanato-9,10-anthracenedione 


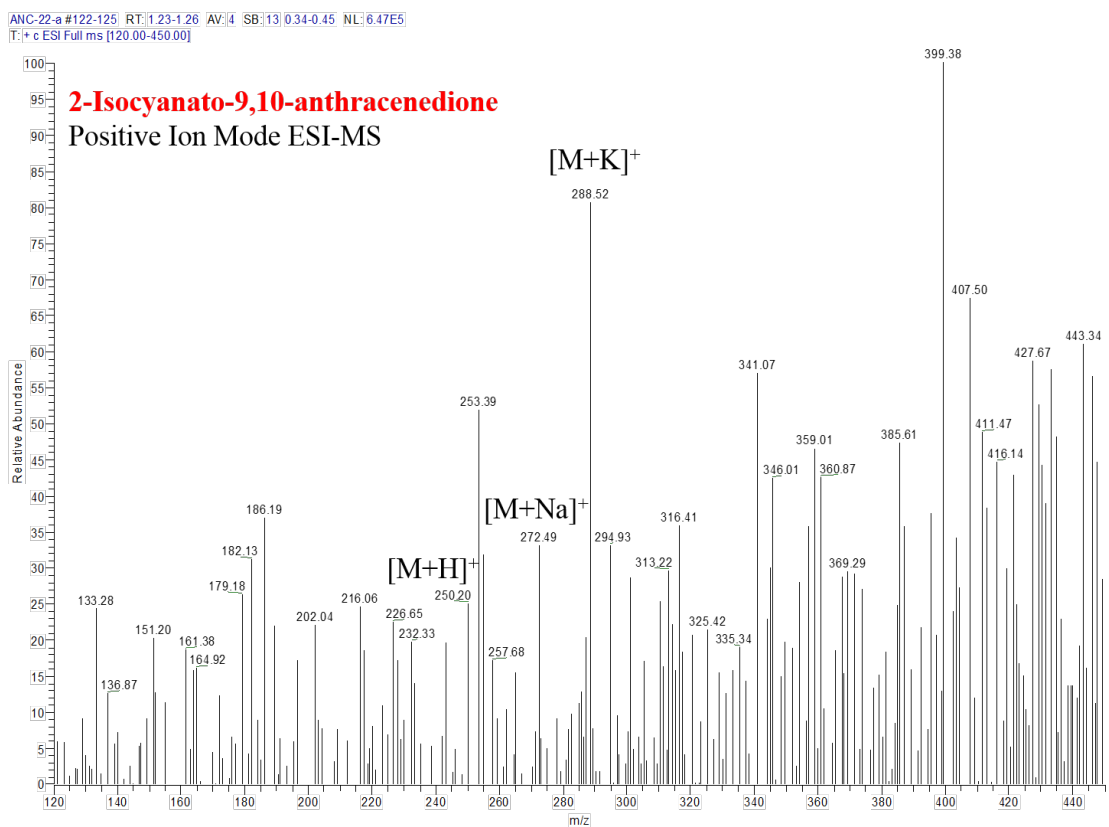

Figure S121: ESI MS of 2-Isocyanato-9,10-anthracenedione

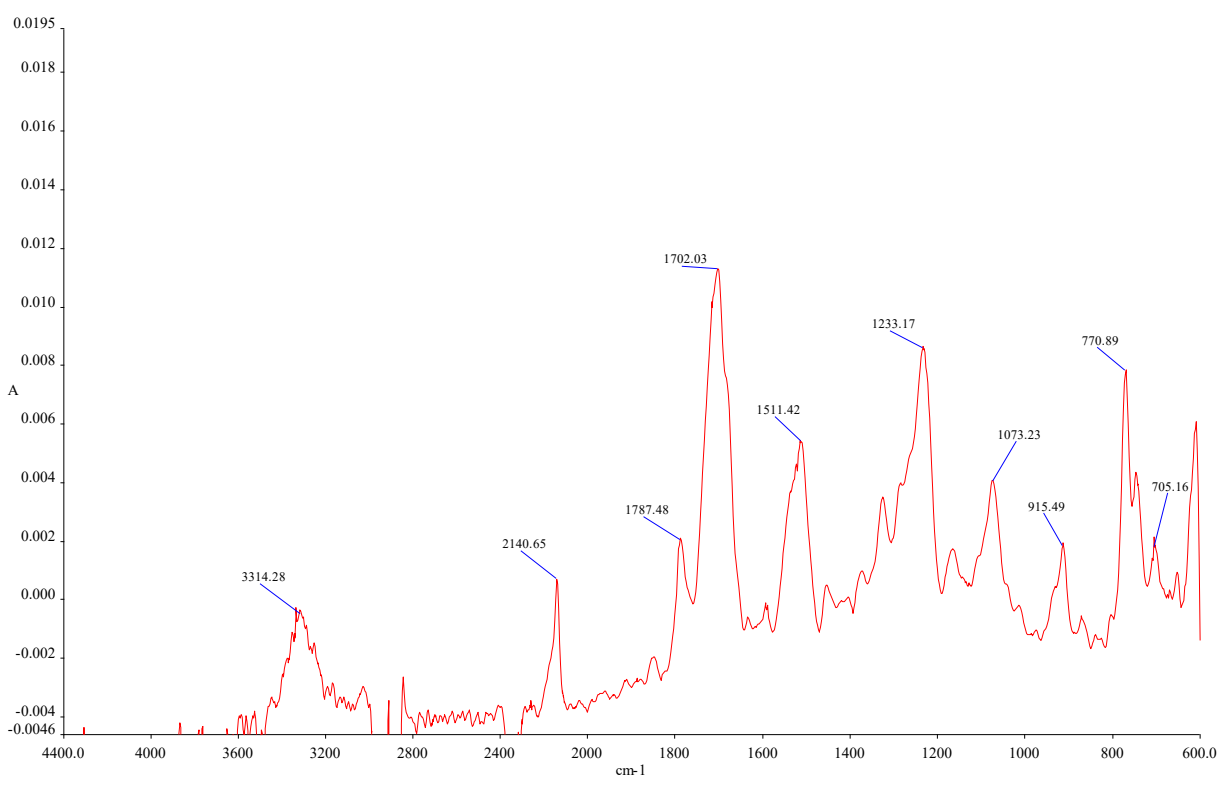

Figure S122: FT IR of 2-Isocyanato-9,10-anthracenedione 


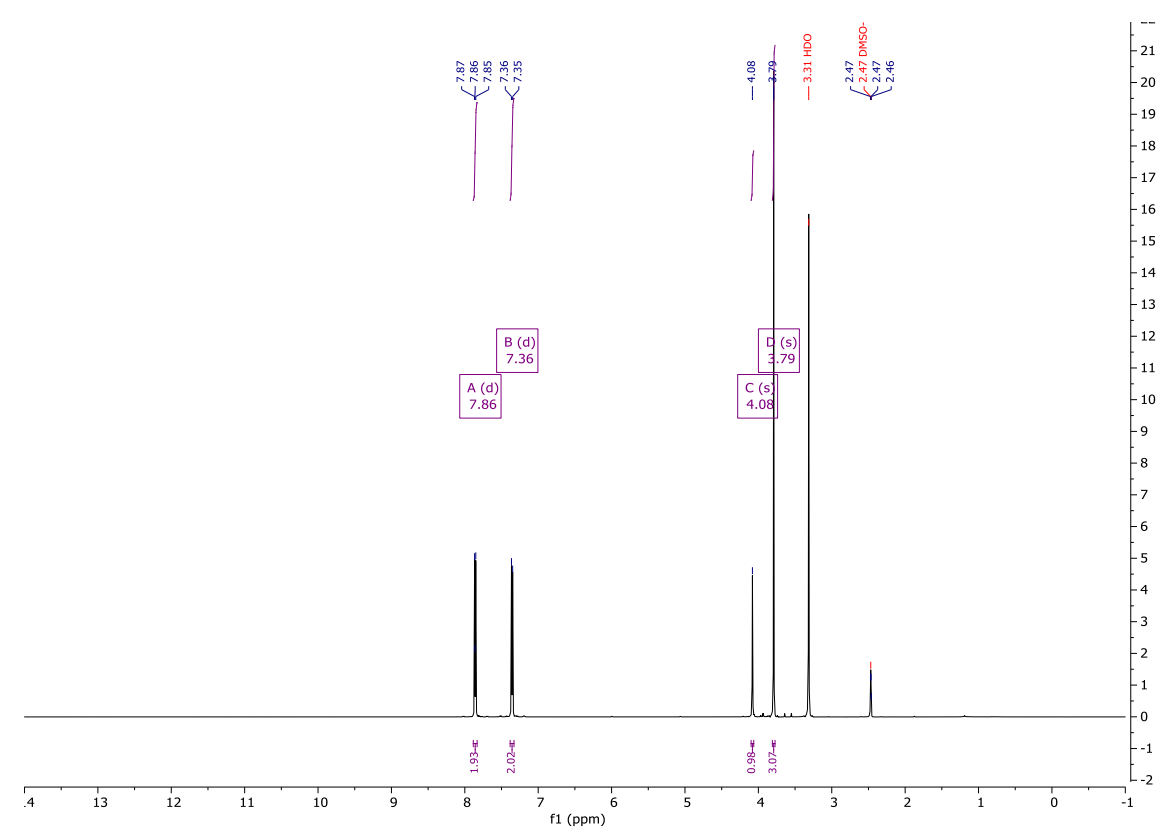

Figure S123: H NMR of Dimethyl 4,4'-methylenebis(benzoate)

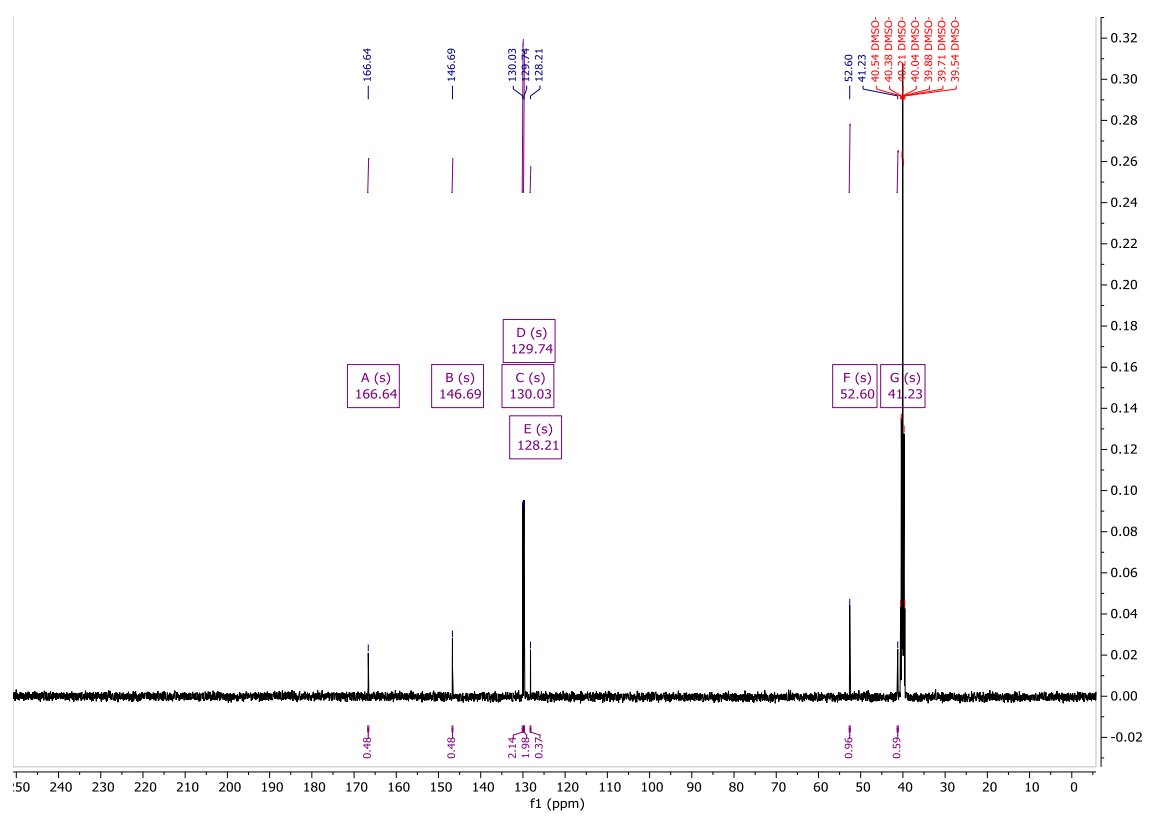

Figure S124: C NMR of Dimethyl 4,4'-methylenebis(benzoate) 


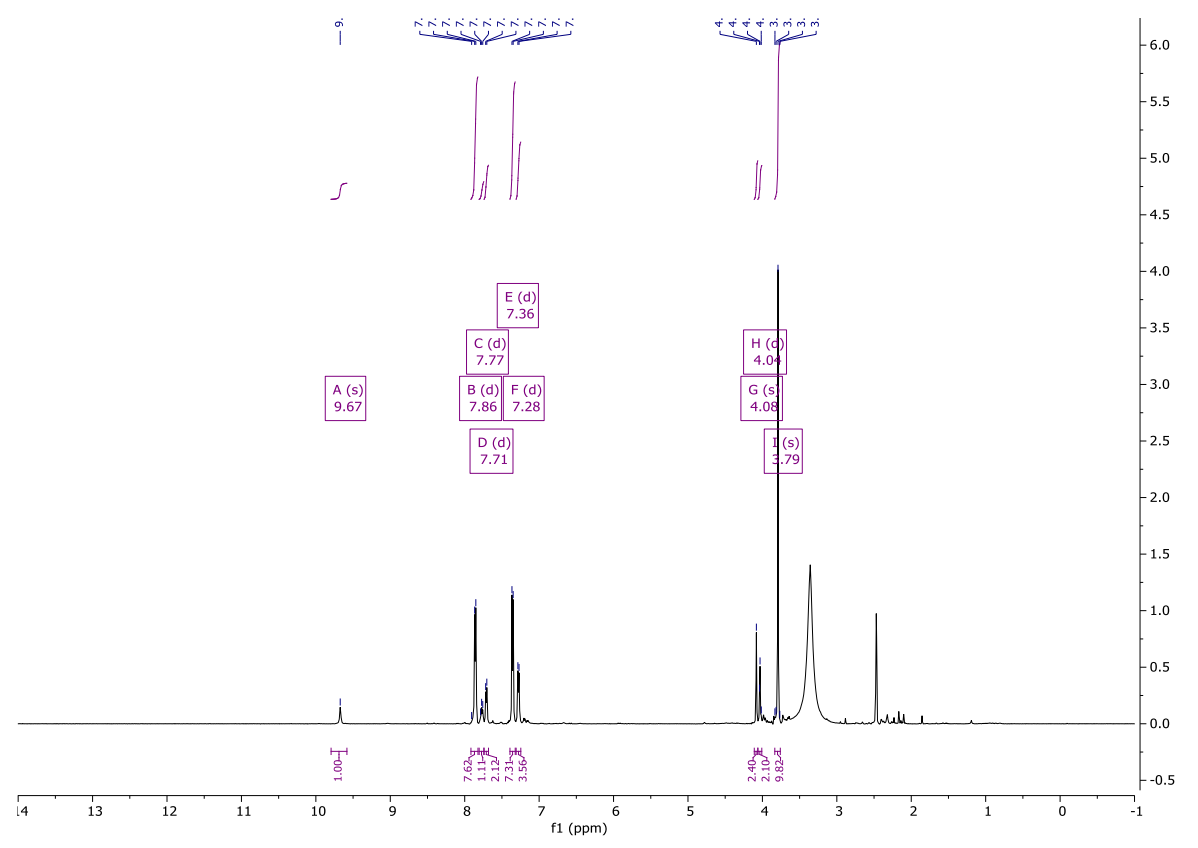

Figure S125: H NMR of Benzoic acid 4,4'-methylenedi-dihydrazide

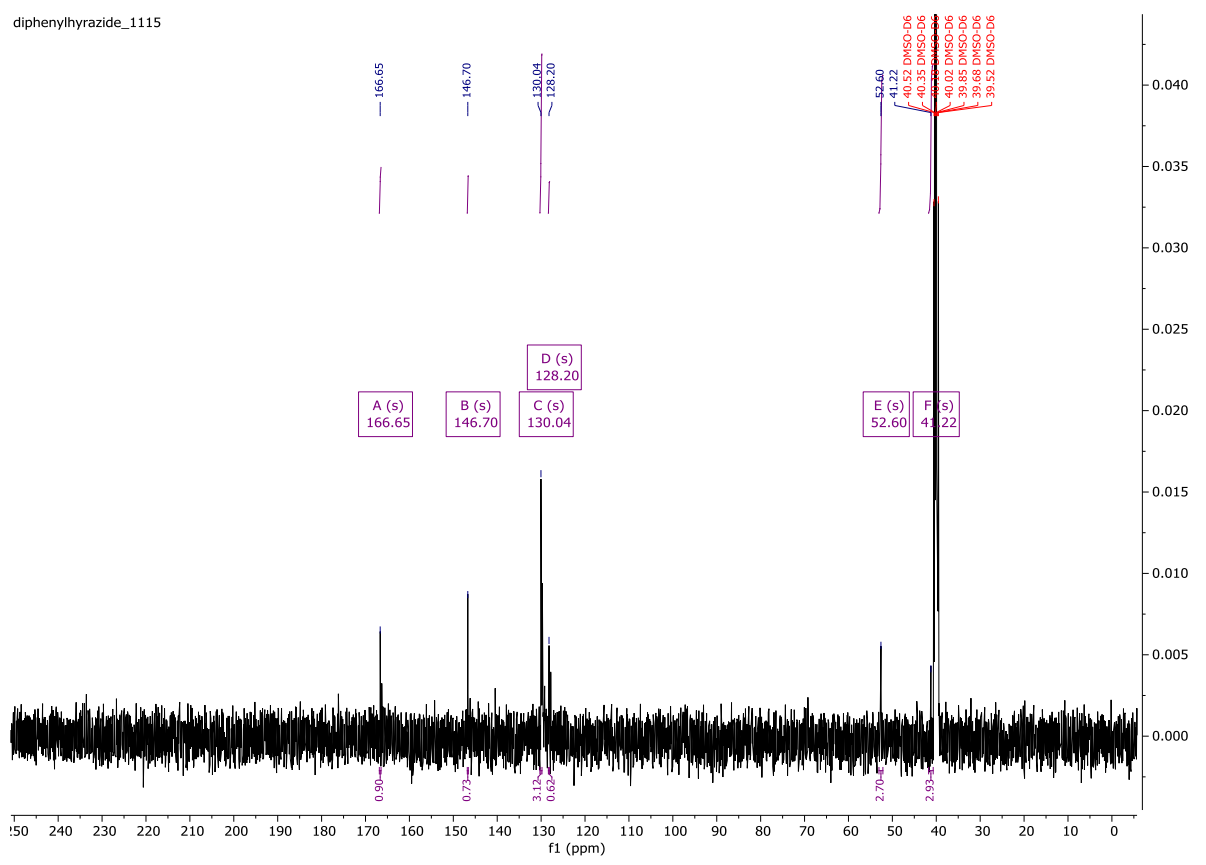

Figure S126: C NMR of Benzoic acid 4,4'-methylenedi-dihydrazide 


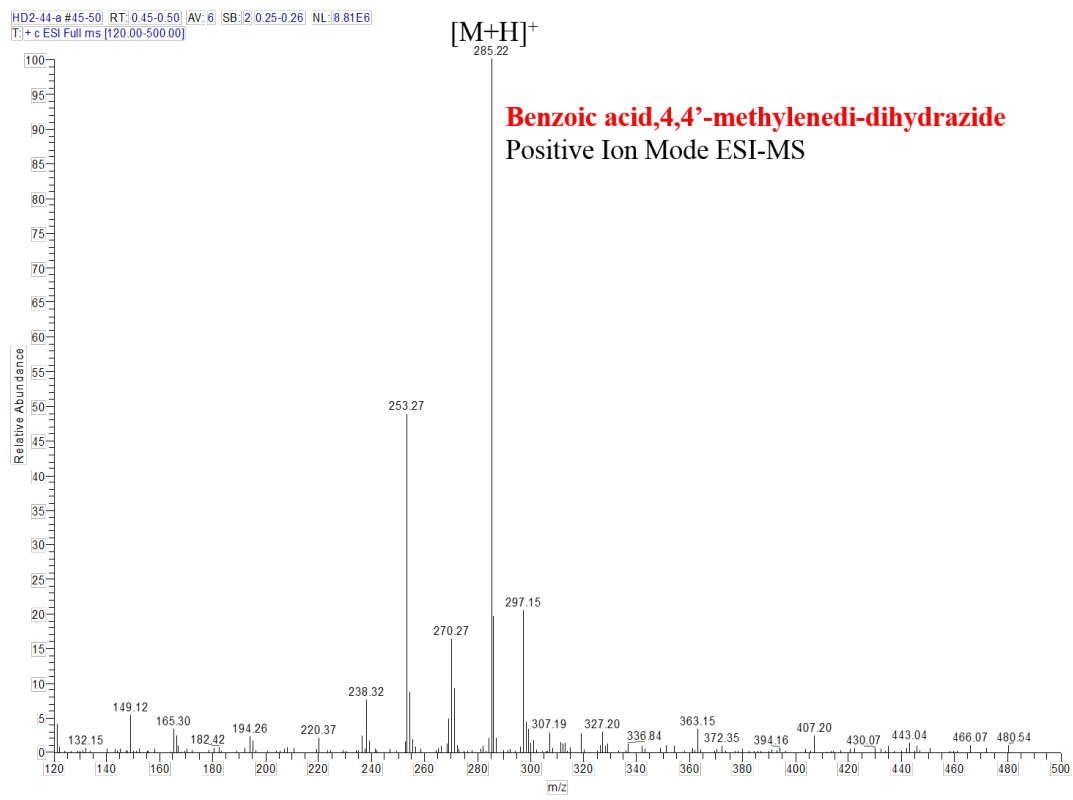

Figure S127: ESI MS of Benzoic acid 4,4'-methylenedi-dihydrazide

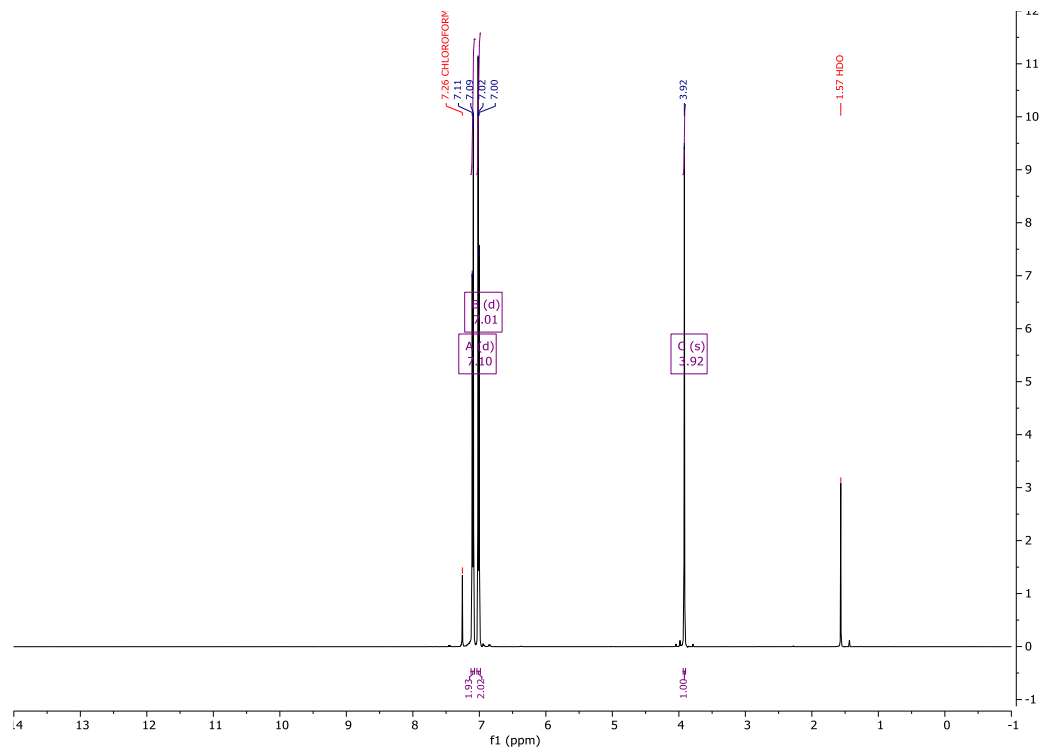

Figure S128: H NMR of 4,4'-methylene diphenyl diisocyanate 


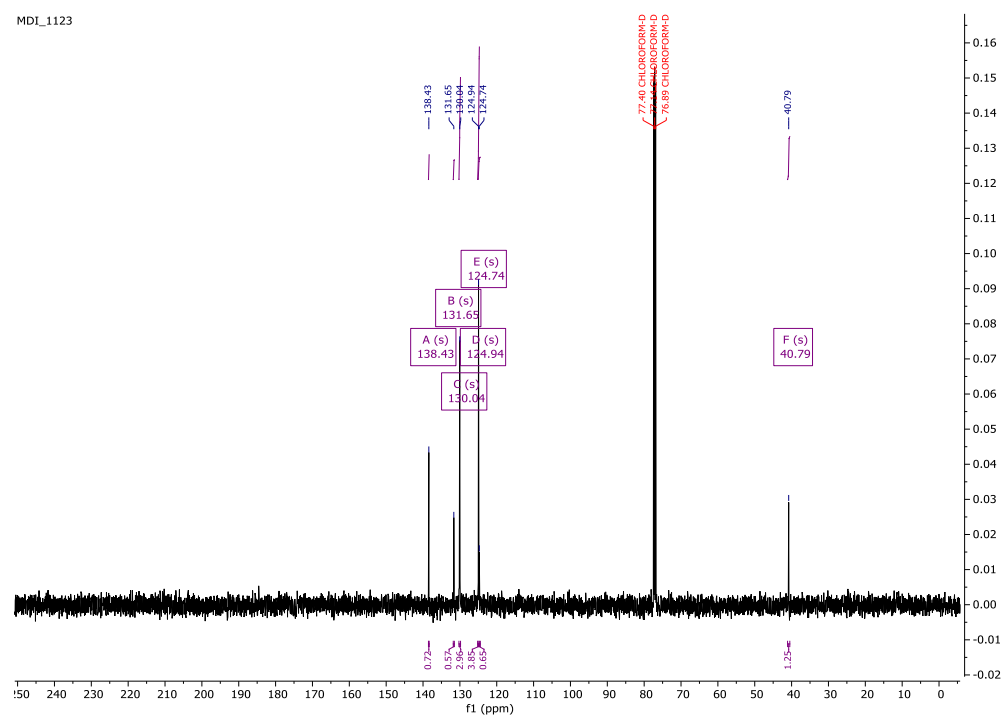

Figure S129: C NMR of 4,4'-methylene diphenyl diisocyanate

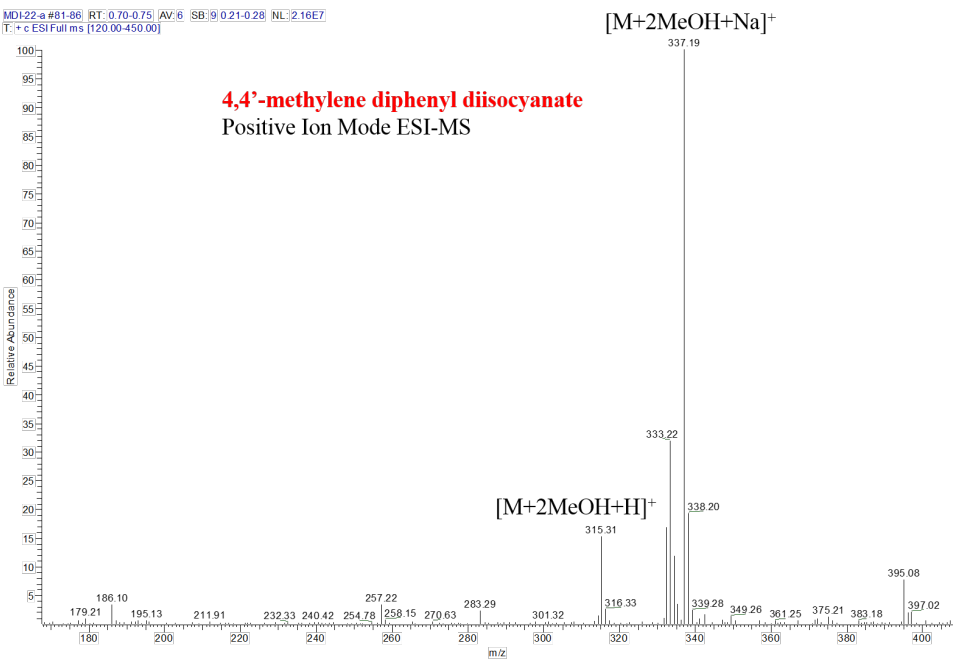

Figure S130: ESI MS of 4,4'-methylene diphenyl diisocyanate 


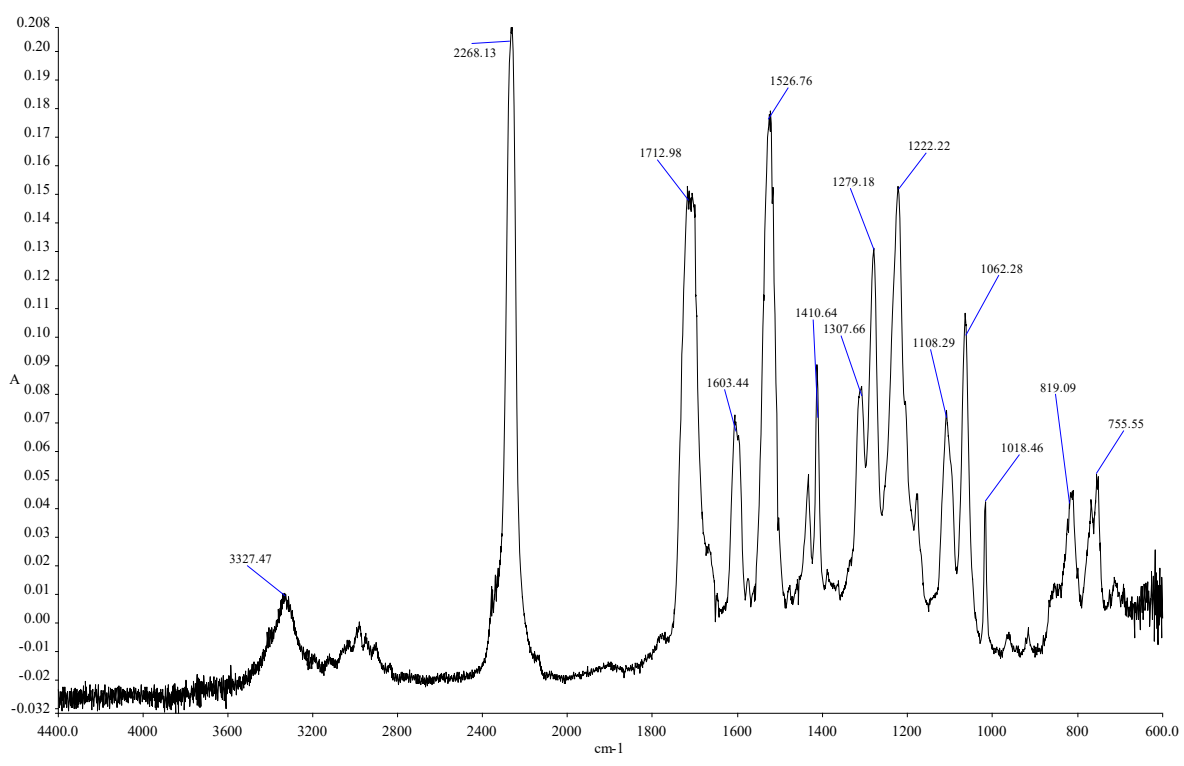

Figure S131: FT IR of 4,4'-methylene diphenyl diisocyanate

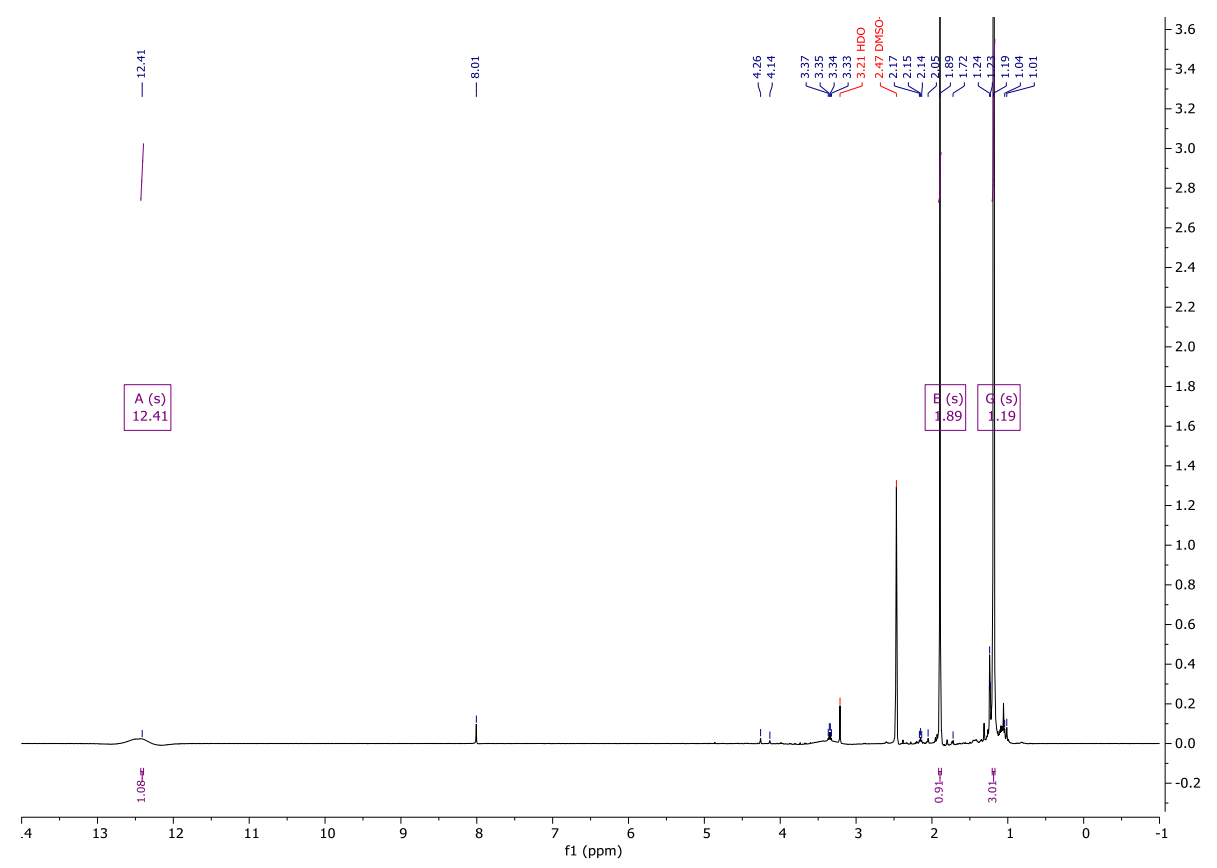

Figure S132. H NMR of 3,3-dimethyl-1,2-cyclopropanedicarboxylic acid 


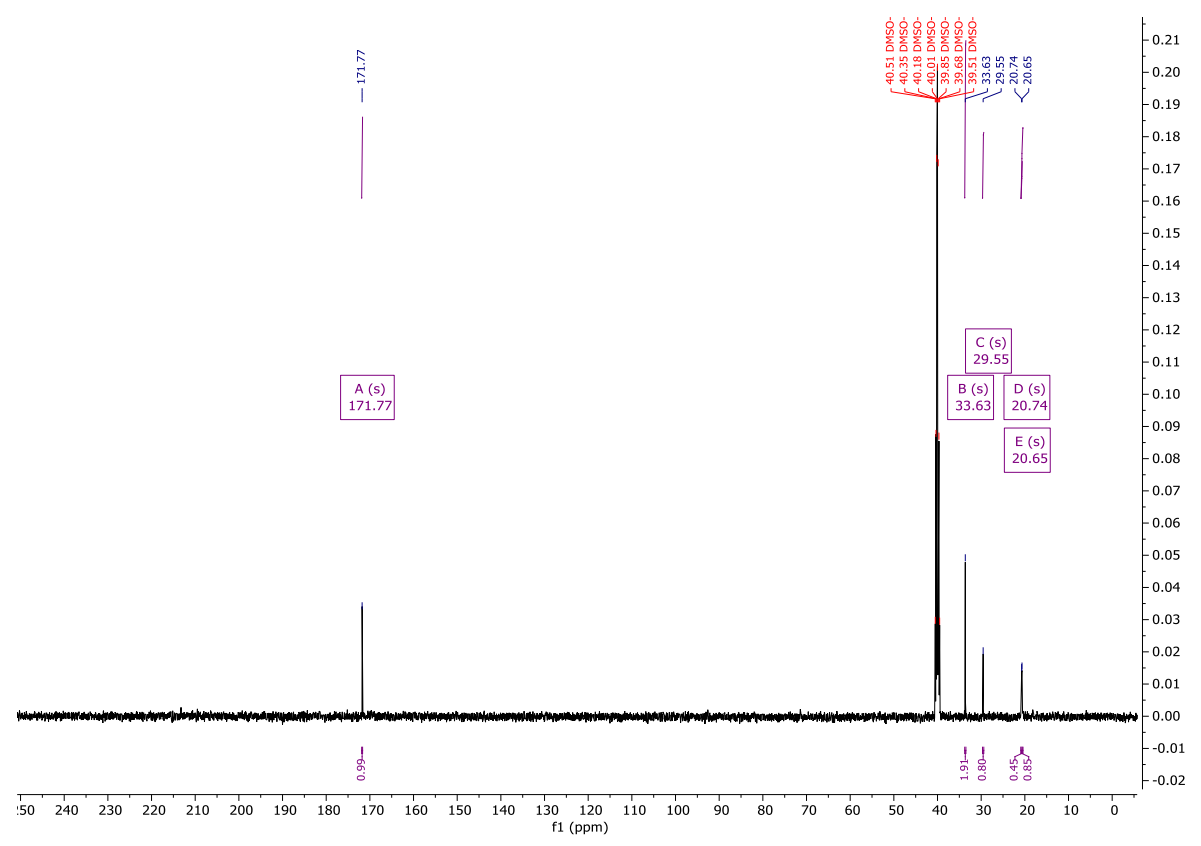

Figure S133. C NMR of 3,3-dimethyl-1,2-cyclopropanedicarboxylic acid

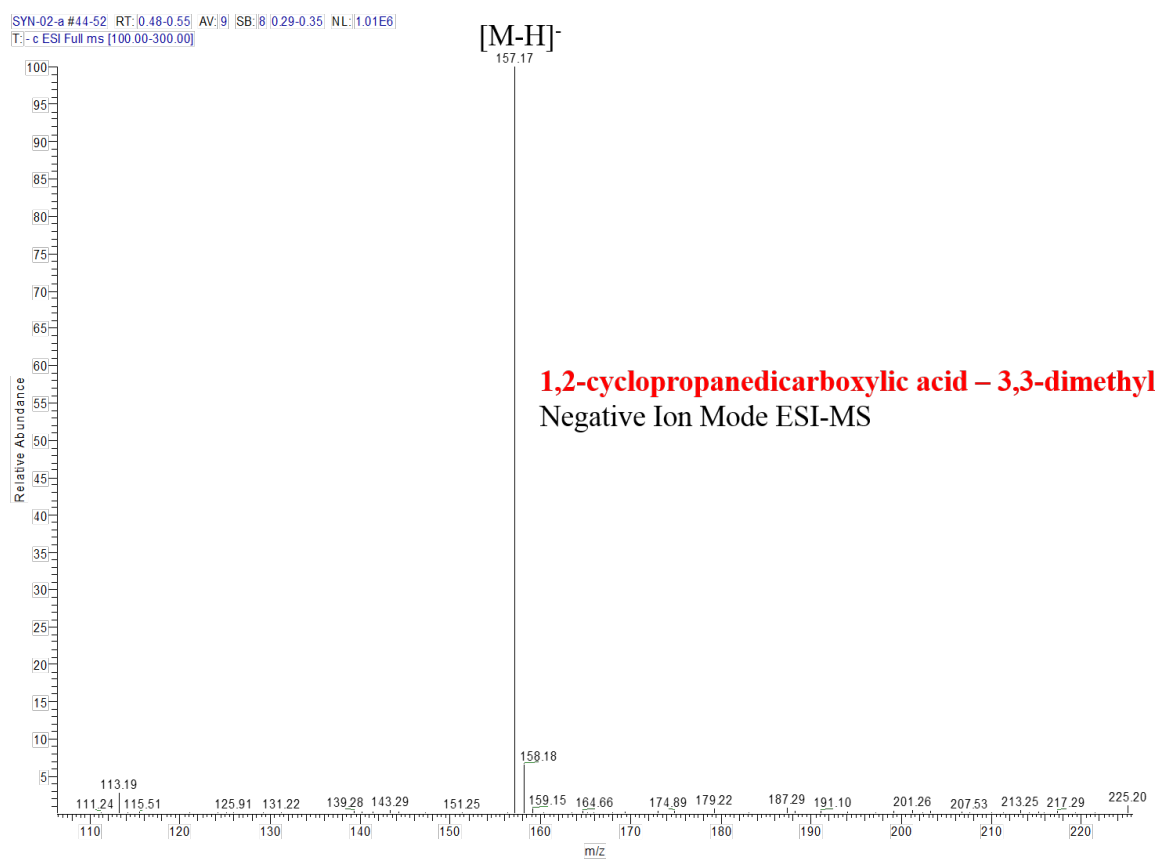

Figure S134. ESI MS of 3,3-dimethyl-1,2-cyclopropanedicarboxylic acid 


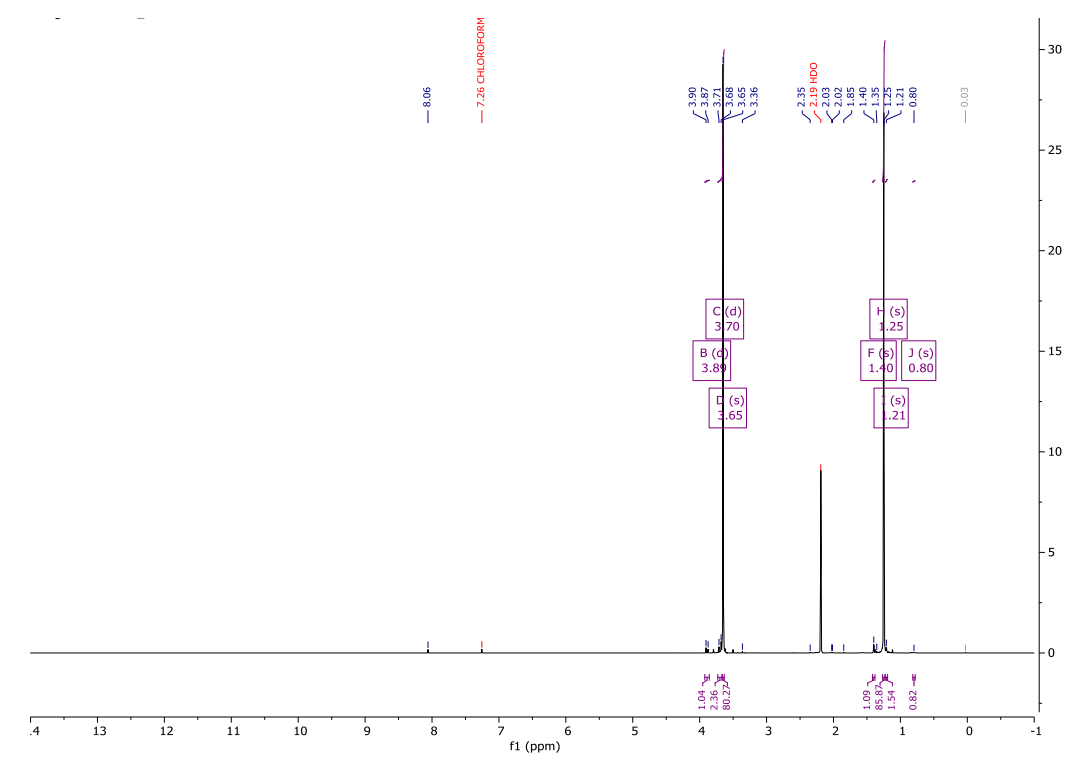

Figure S135: H NMR of 3,3-dimethyl-1,2-cyclopropanedicarboxylic acid-1,2-dimethyl ester

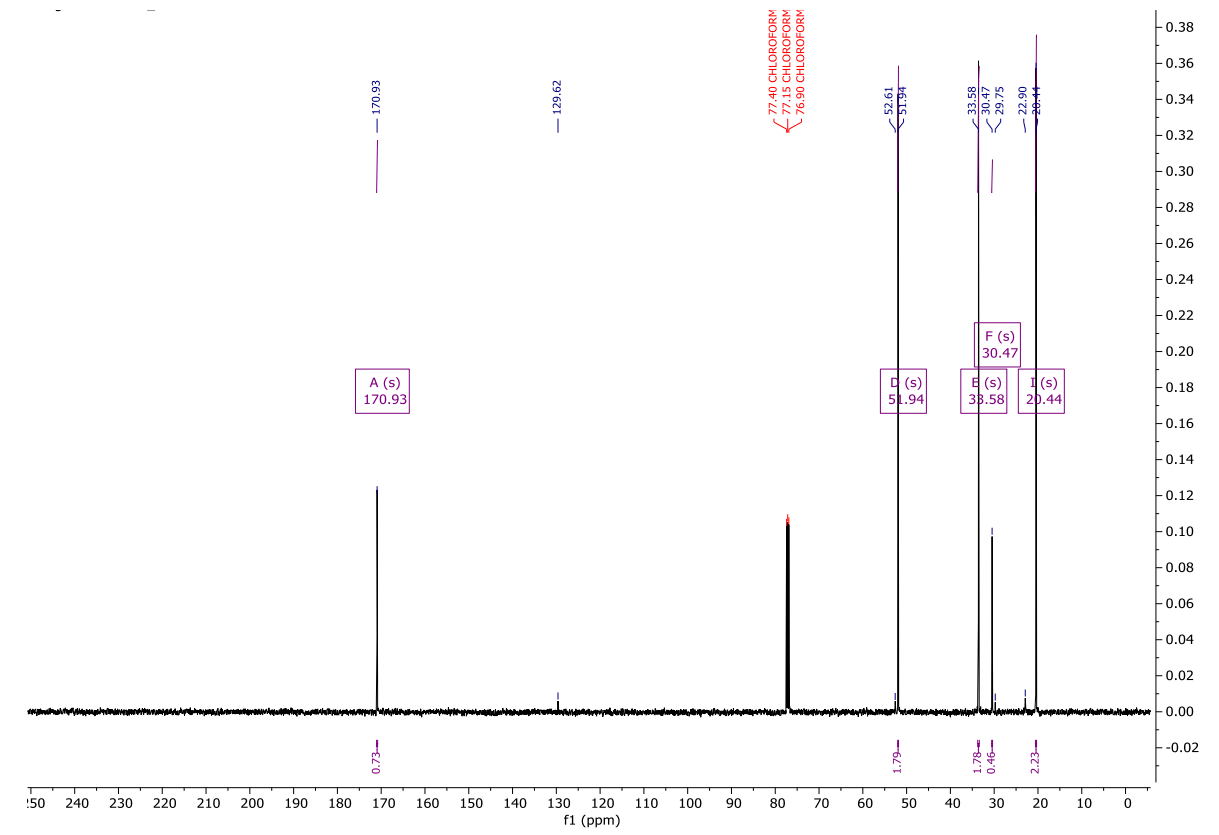

Figure S136: C NMR of 3,3-dimethyl-1,2-cyclopropanedicarboxylic acid-1,2-dimethyl ester 


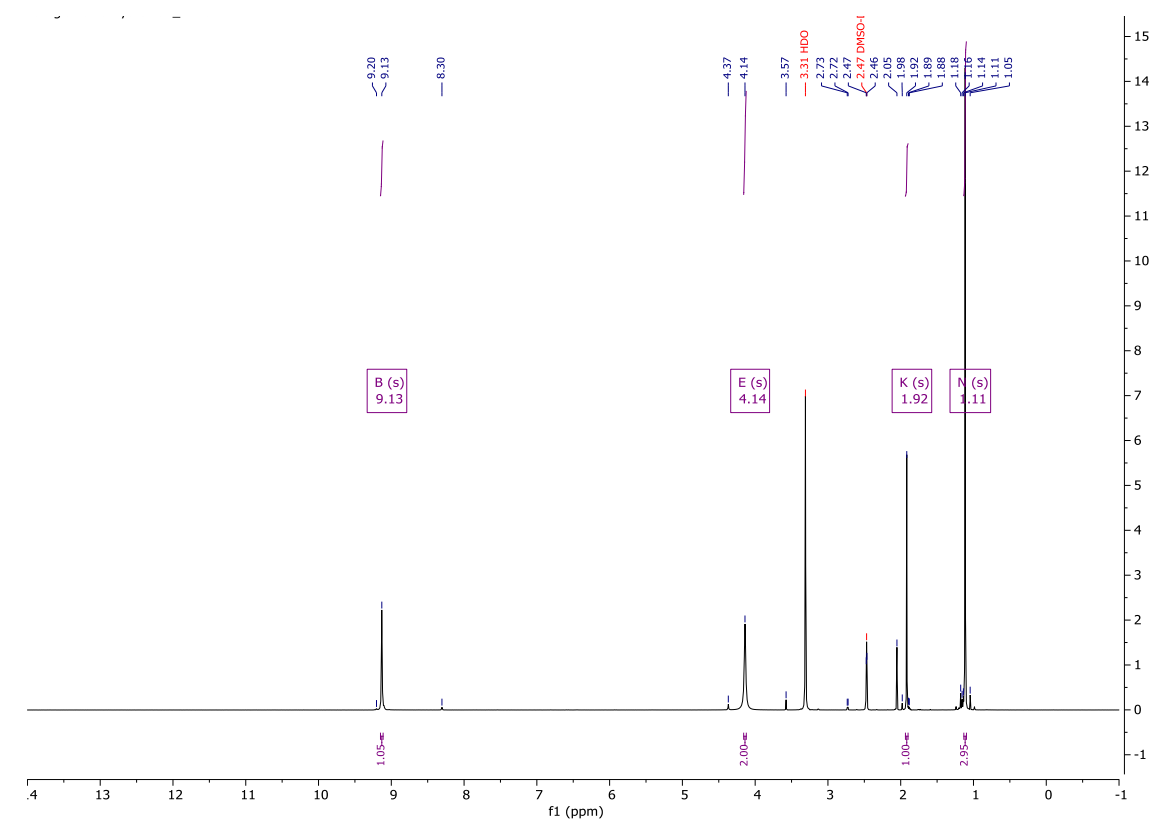

Figure S137: H NMR of 1,2-cyclopropanedicarboxylic acid-3,3-dimethyl-1,2-dihydrazide

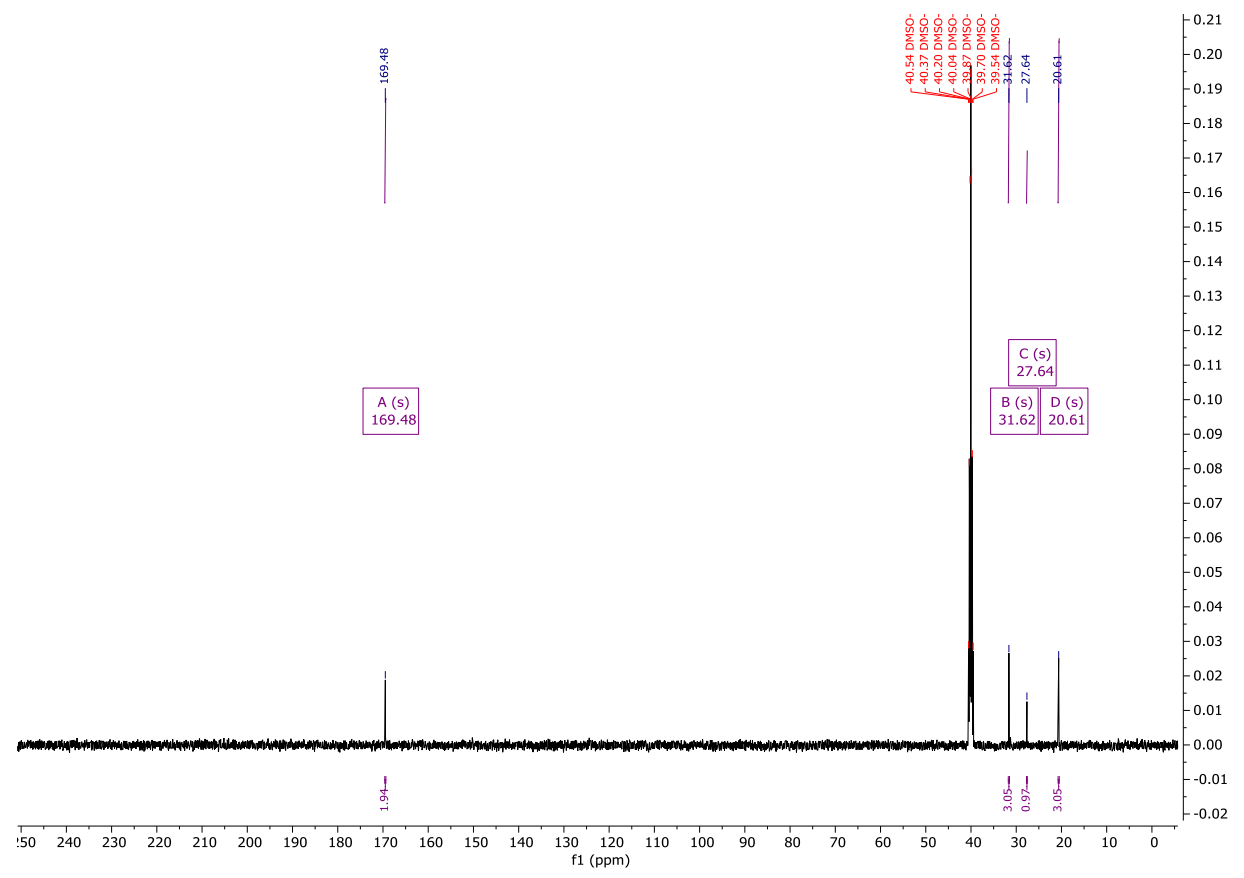

Figure S138: C NMR of 1,2-cyclopropanedicarboxylic acid-3,3-dimethyl-1,2-dihydrazide 


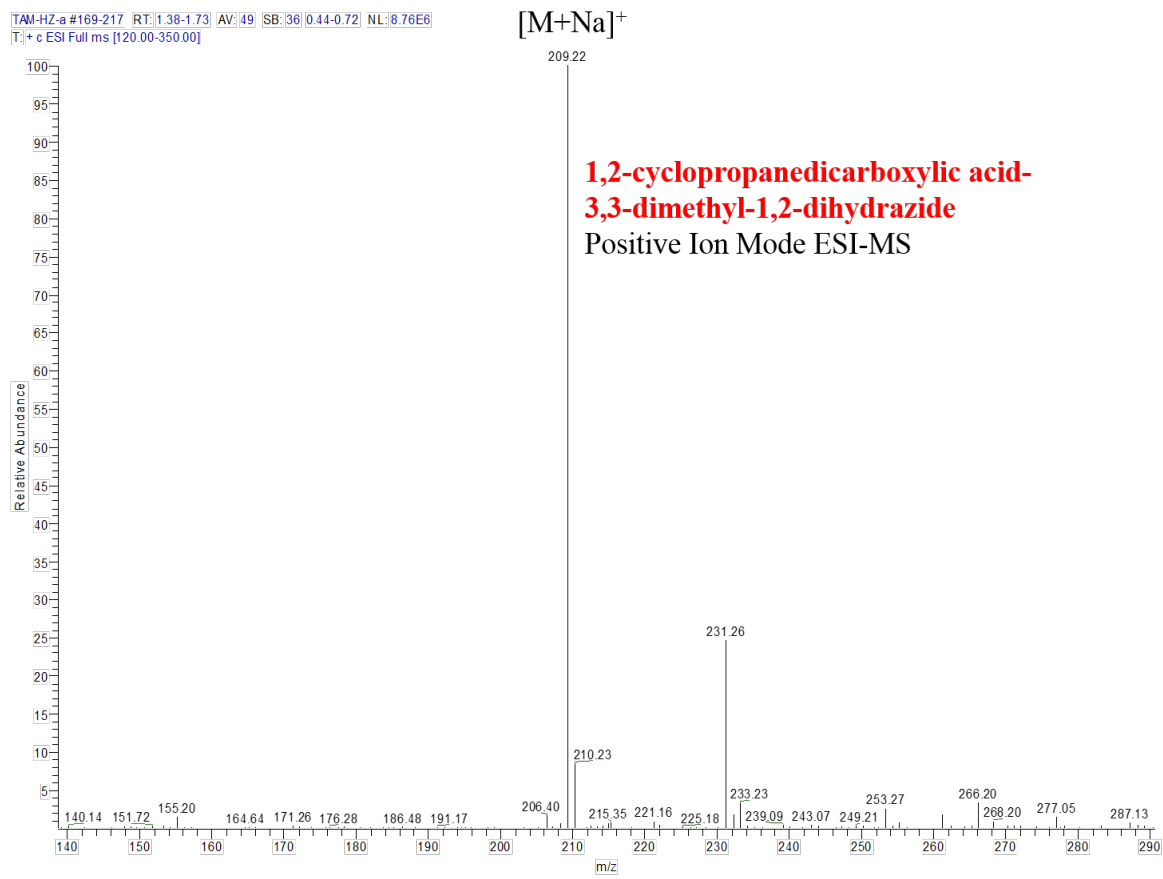

Figure S139: ESI MS of 1,2-cyclopropanedicarboxylic acid-3,3-dimethyl-1,2-dihydrazide

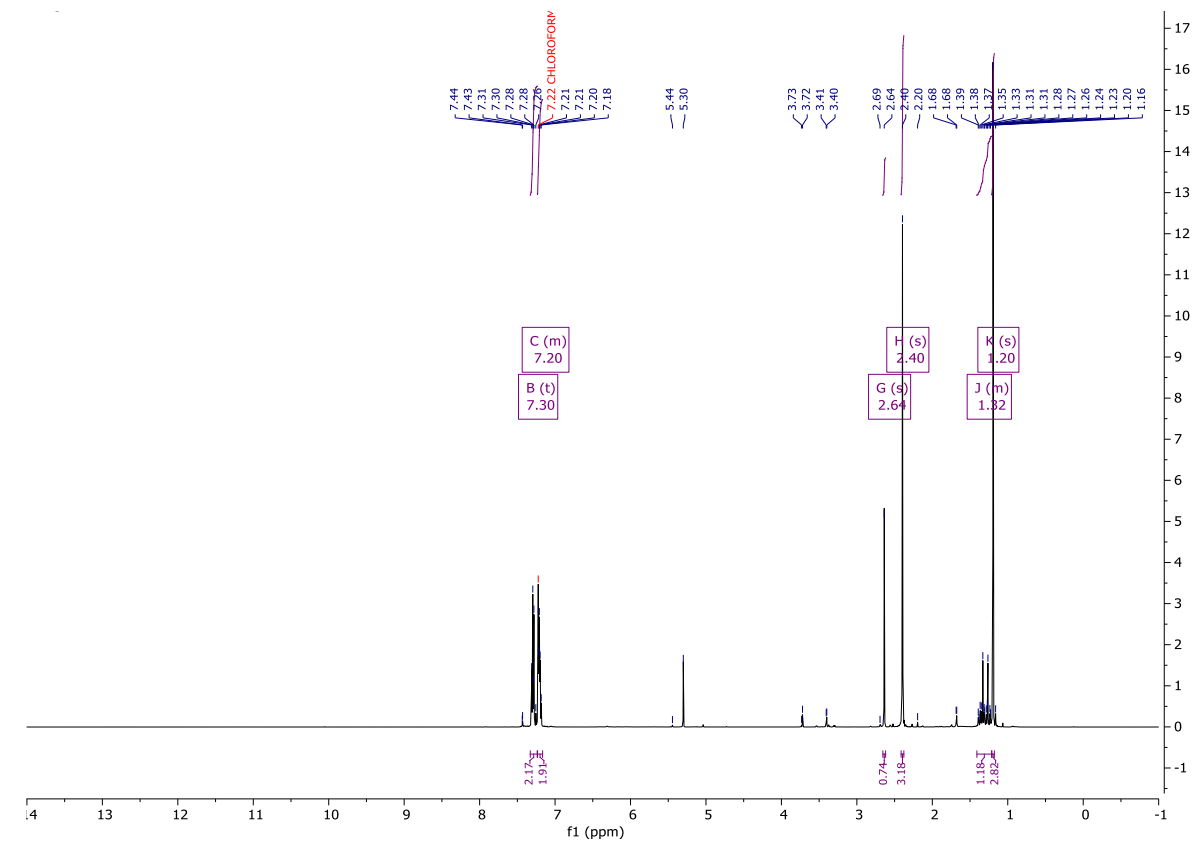

Figure S140: H NMR of cyclopropane-2,3-diisocyanato-1,1-dimethyl 


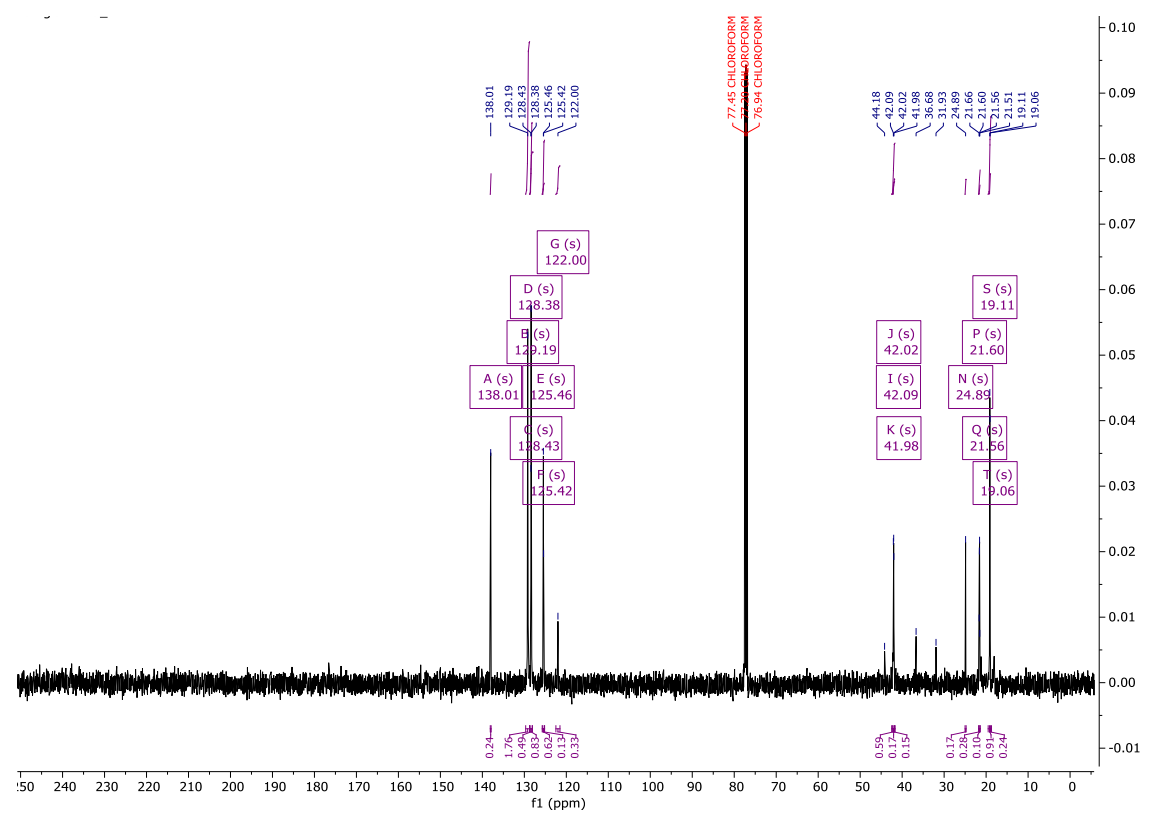

Figure S141: C NMR of cyclopropane-2,3-diisocyanato-1,1-dimethyl

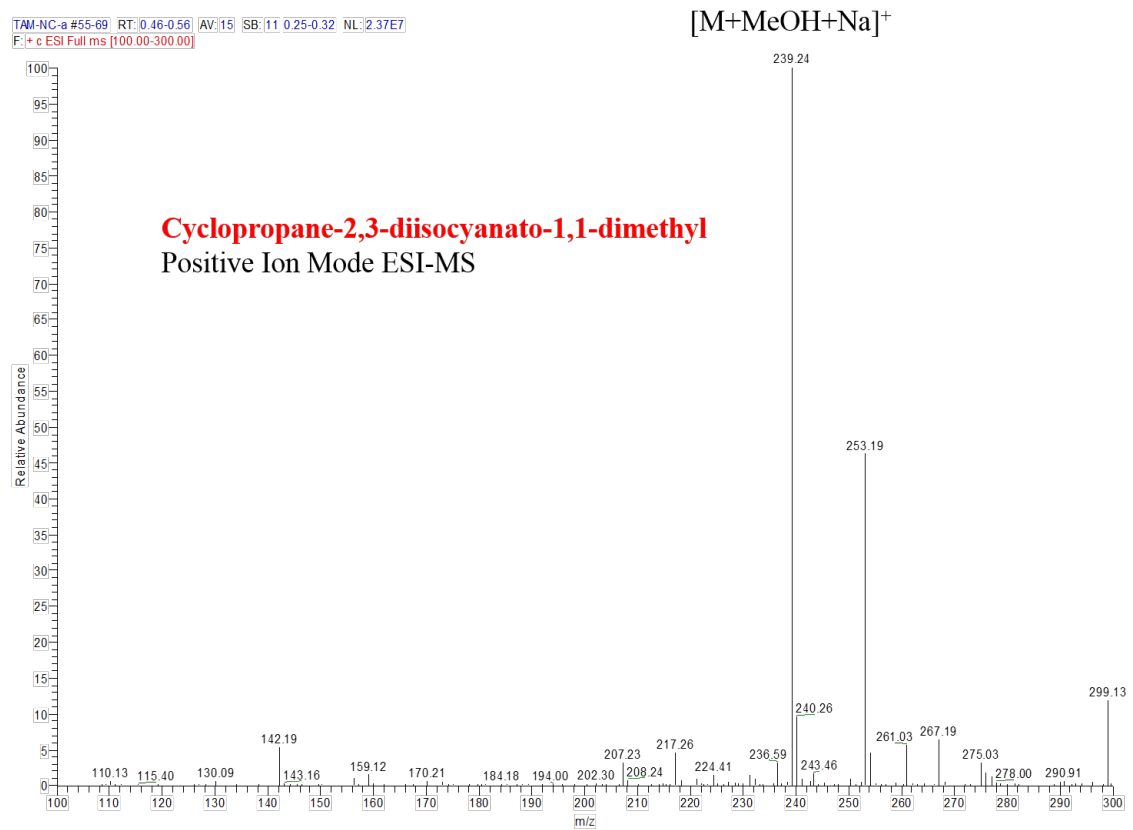

Figure S142: ESI MS of cyclopropane-2,3-diisocyanato-1,1-dimethyl 


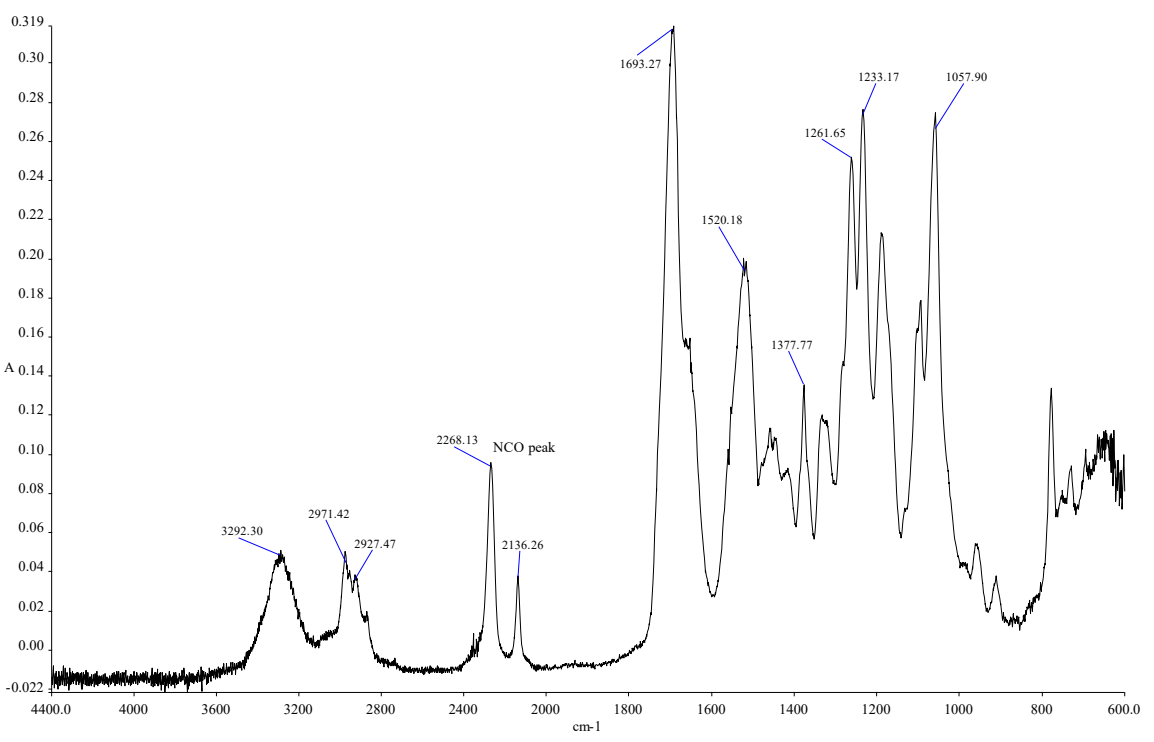

Figure S143: FT IR of cyclopropane-2,3-diisocyanato-1,1-dimethyl

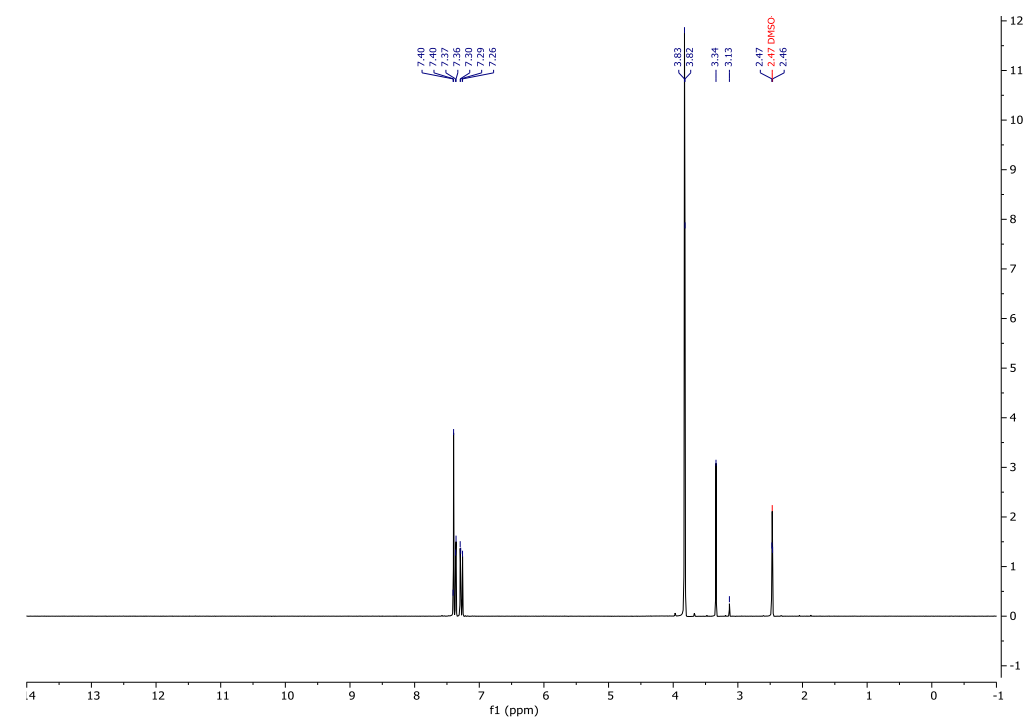

Figure S144: H NMR of 2,5-furandicarboxylic acid, 2,5-dimethyl ester 


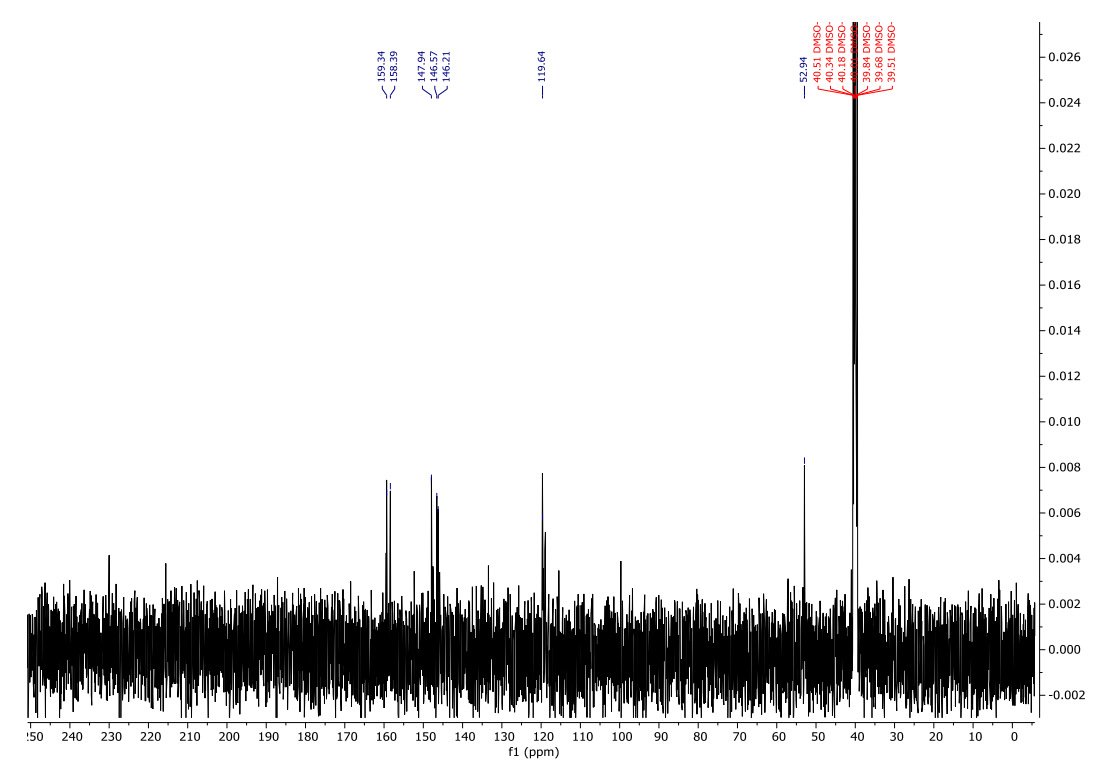

Figure S145: C NMR of 2,5-furandicarboxylic acid, 2,5-dimethyl ester

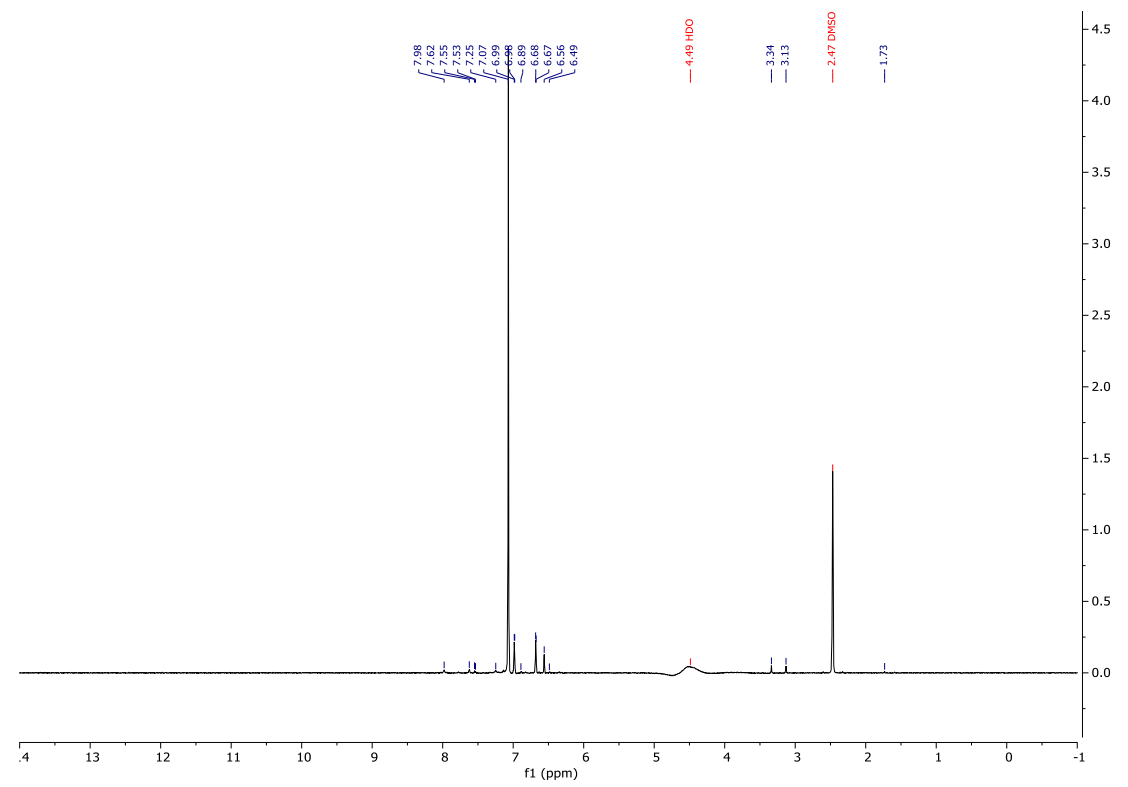

Figure S146. H NMR of 2,5-furandicarboxylic acid, 2,5-dihydrazide 


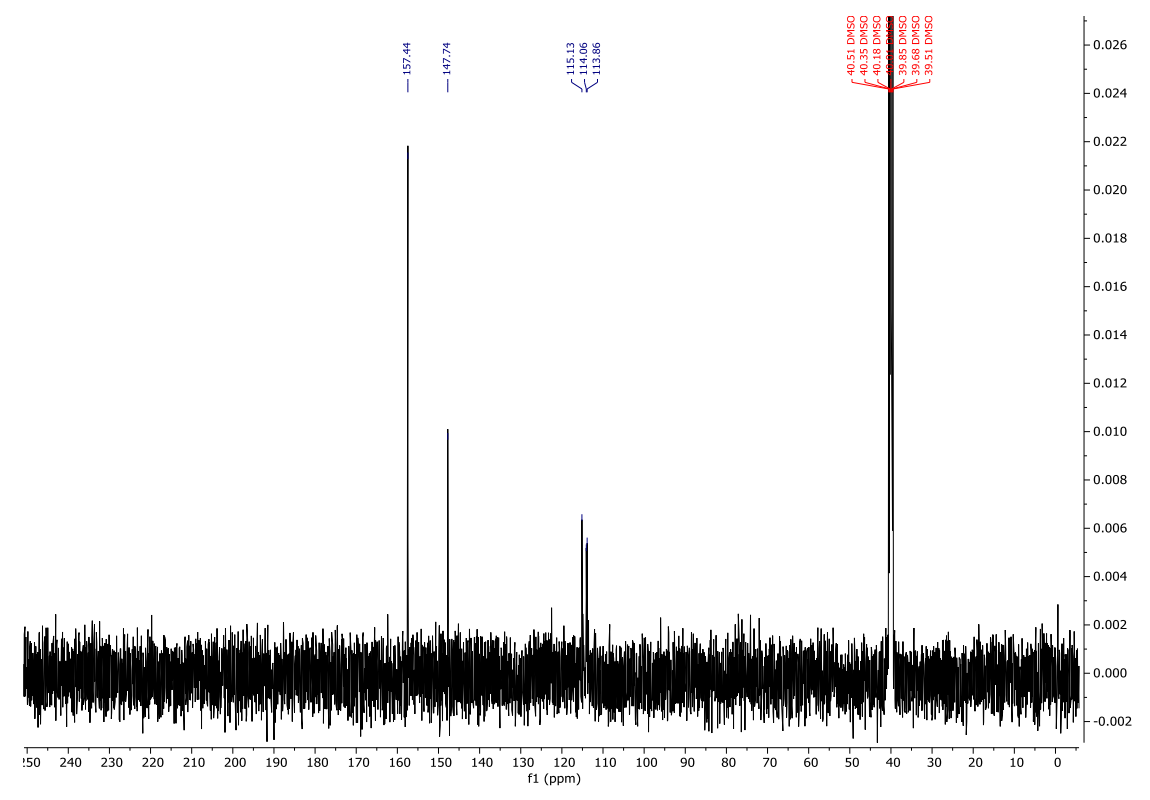

Figure S147. C NMR of 2,5-furandicarboxylic acid, 2,5-dihydrazide

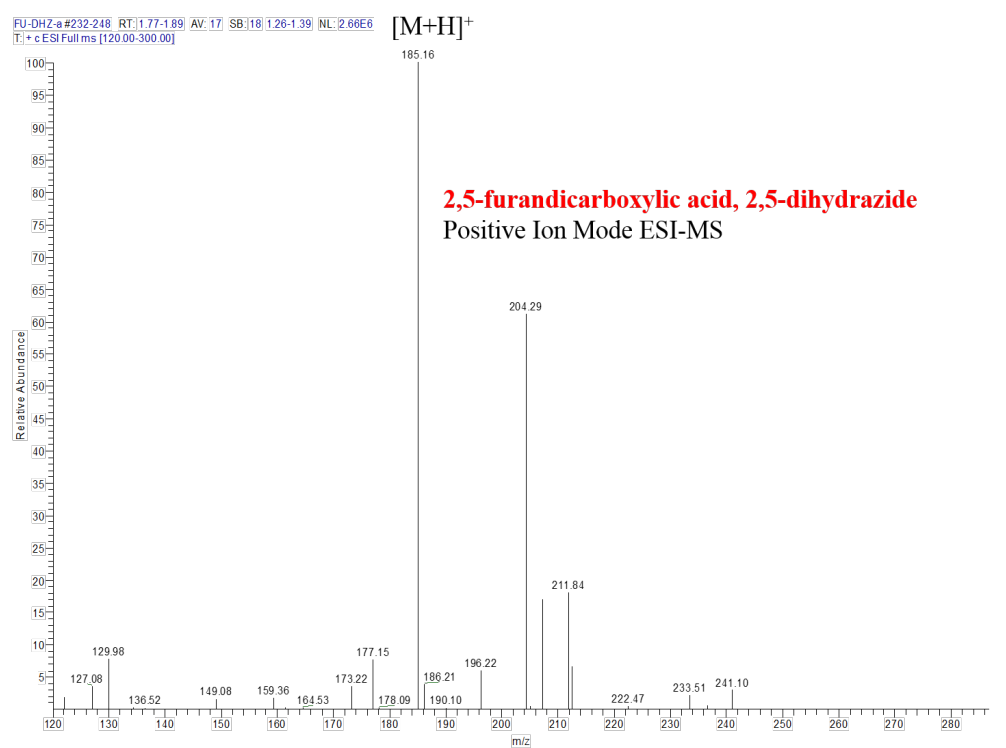

Figure S148. ESI MS of 2,5-furandicarboxylic acid, 2,5-dihydrazide 


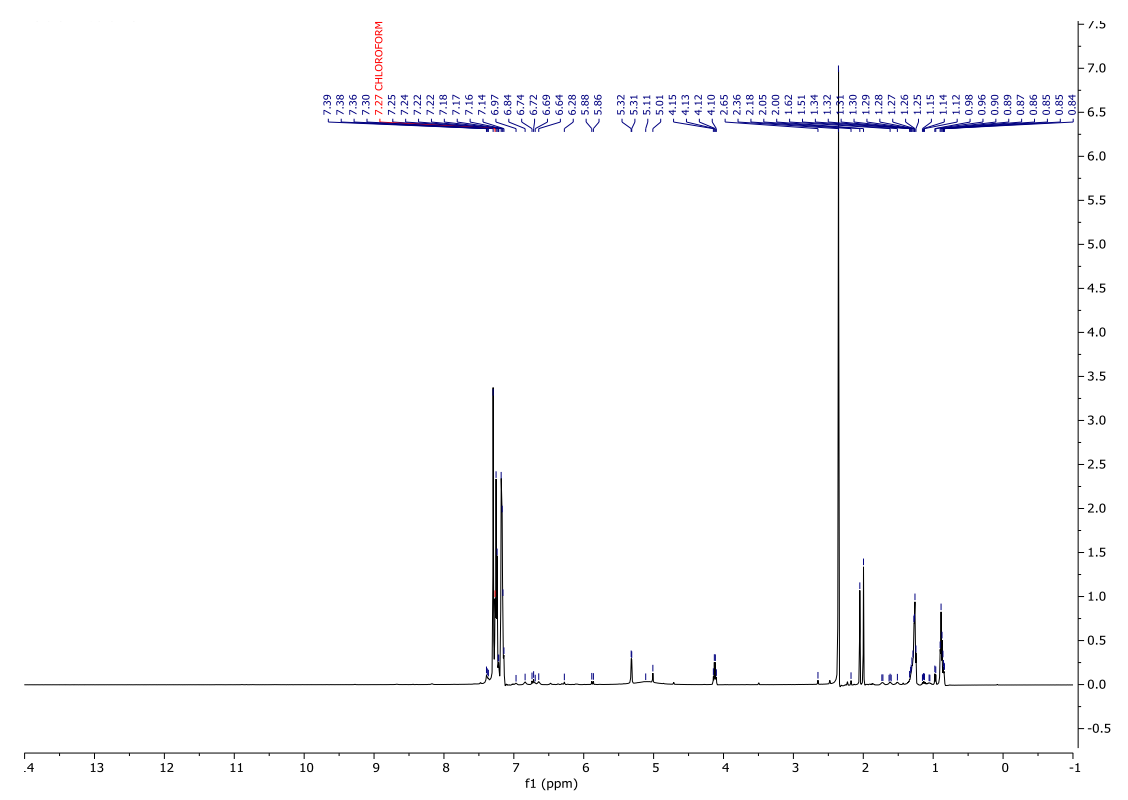

Figure S149: H NMR of 2,5-diisocyanato furan

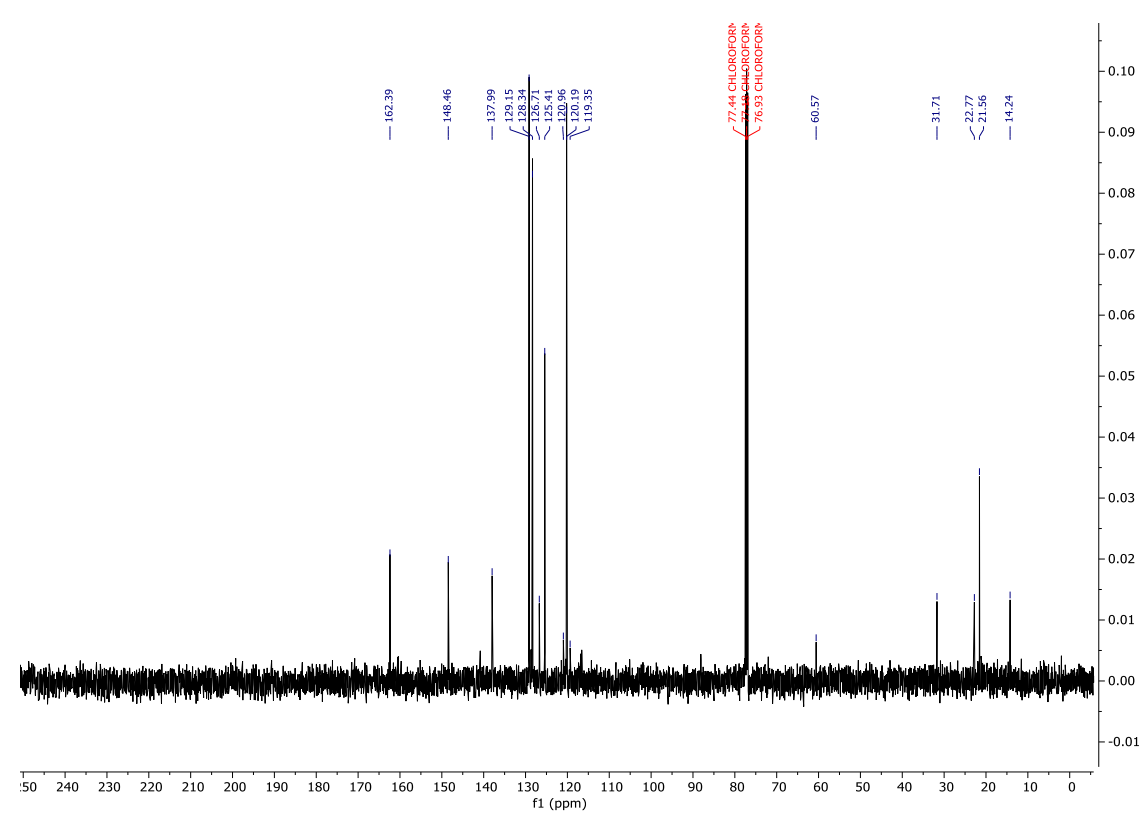

Figure S150. C NMR of 2,5-diisocyanato furan 


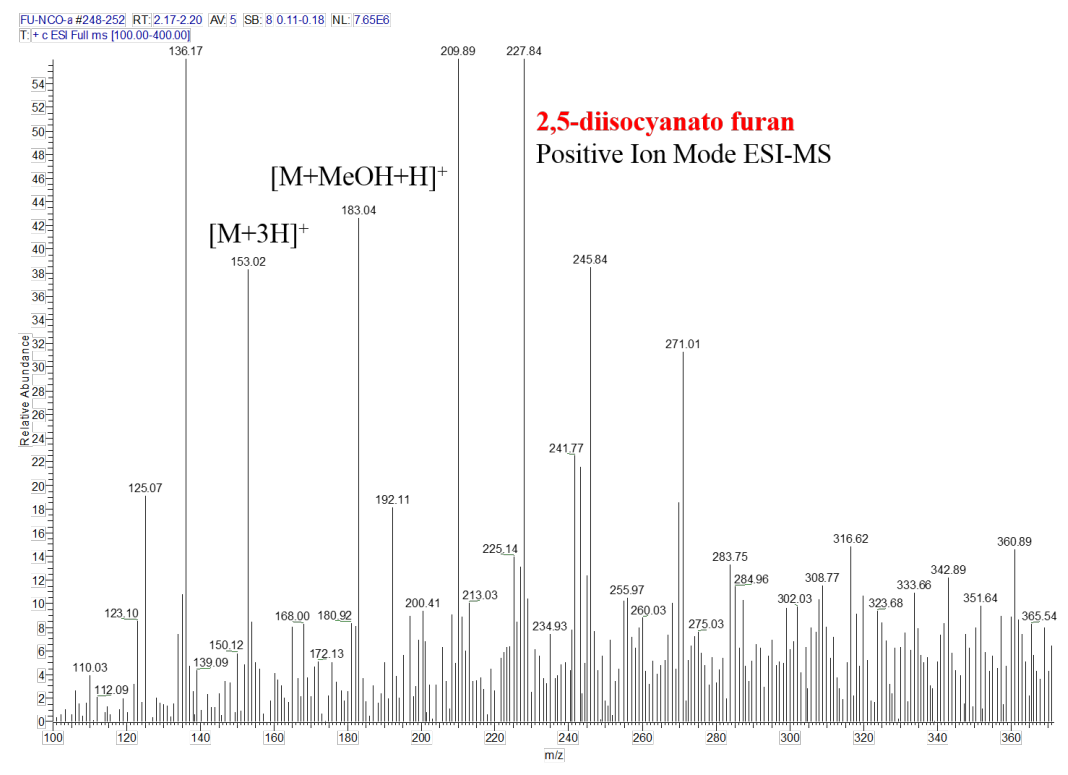

Figure S151: ESI MS of 2,5-diisocyanato furan

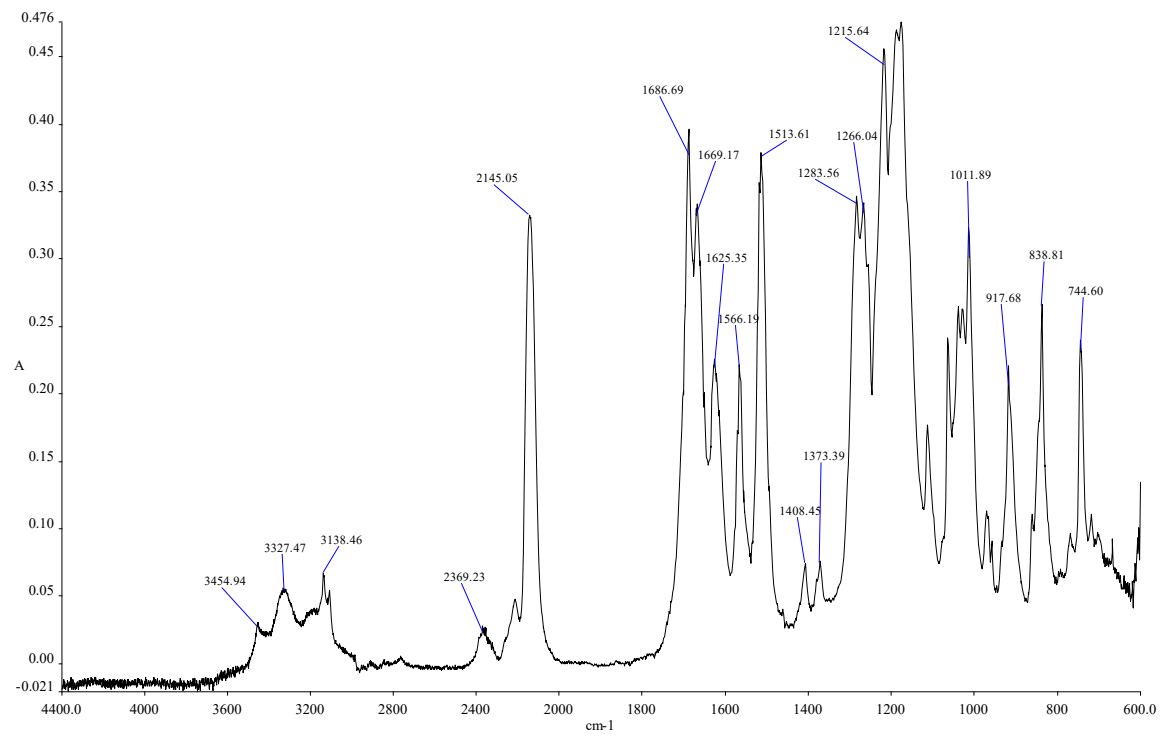

Figure S152: FT IR of 2,5-diisocyanato furan 


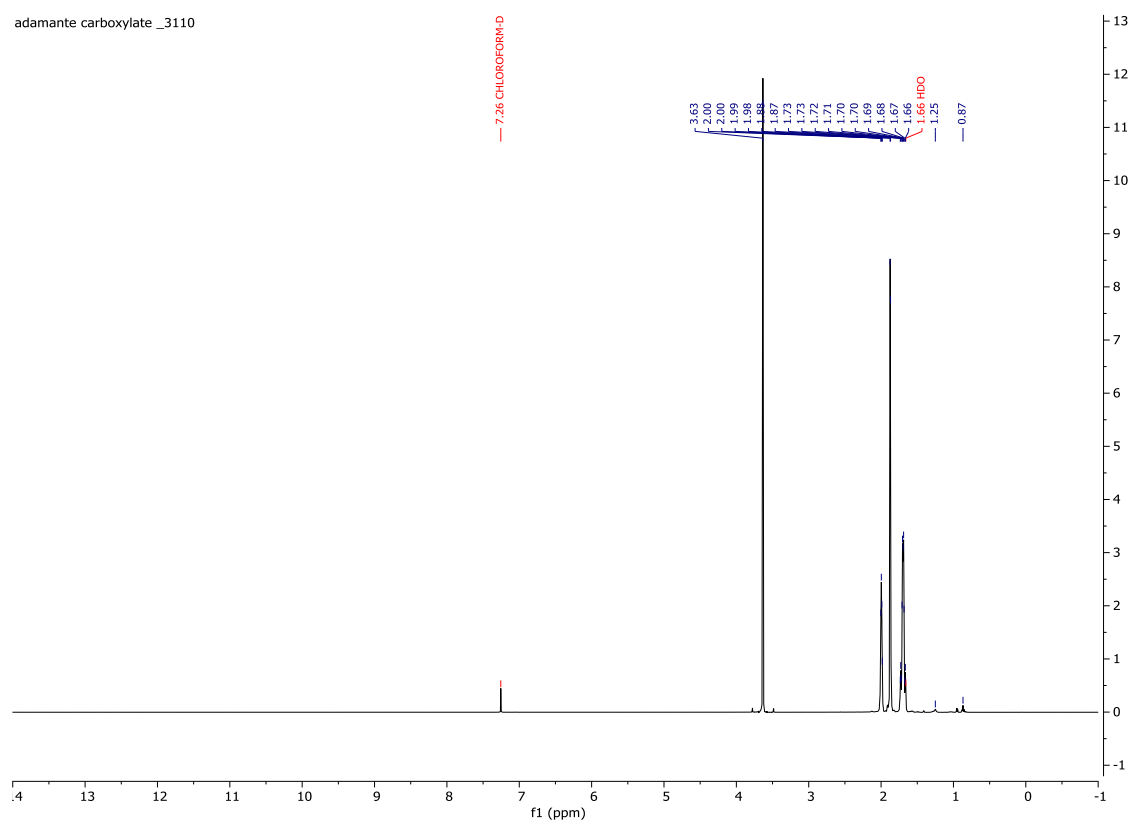

Figure S153: H NMR of Methyl adamantane-1-carboxylate

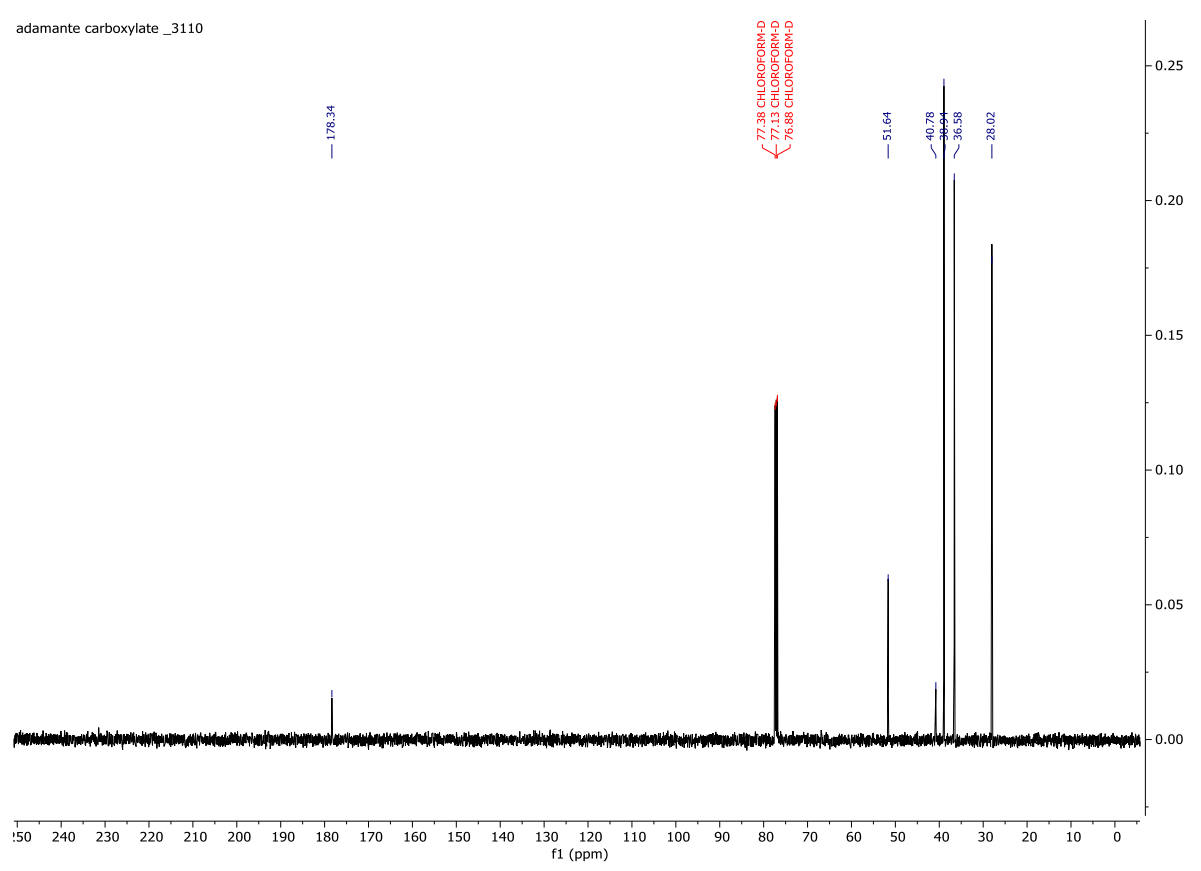

Figure S154: C NMR of Methyl adamantane-1-carboxylate 


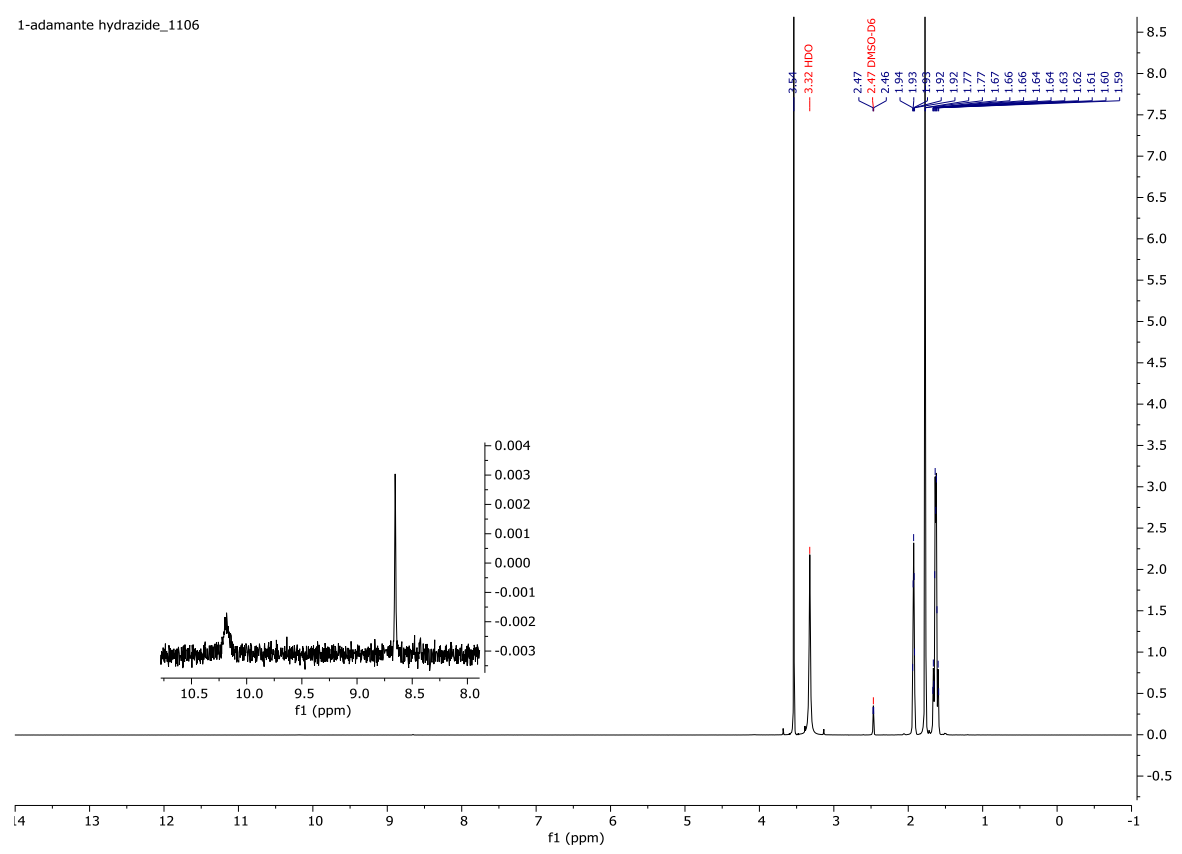

Figure S155: H NMR of Adamantane-1-carbohydrazide

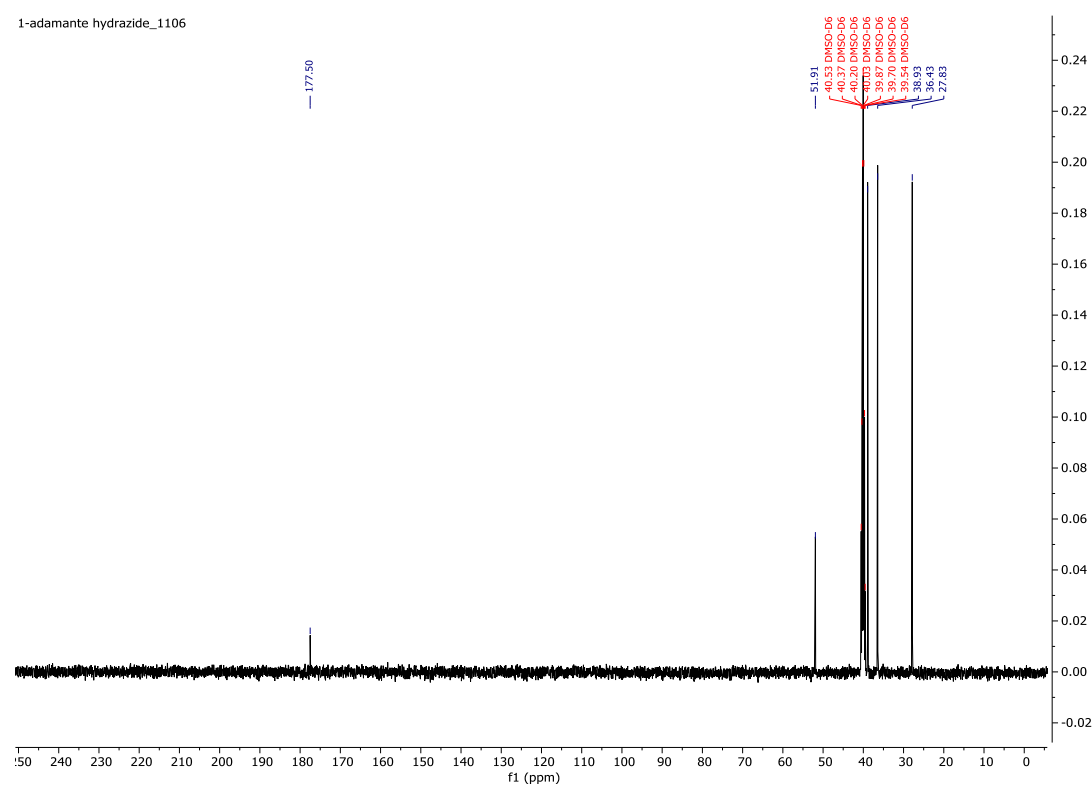

Figure S156: C NMR of Adamantane-1-carbohydrazide 


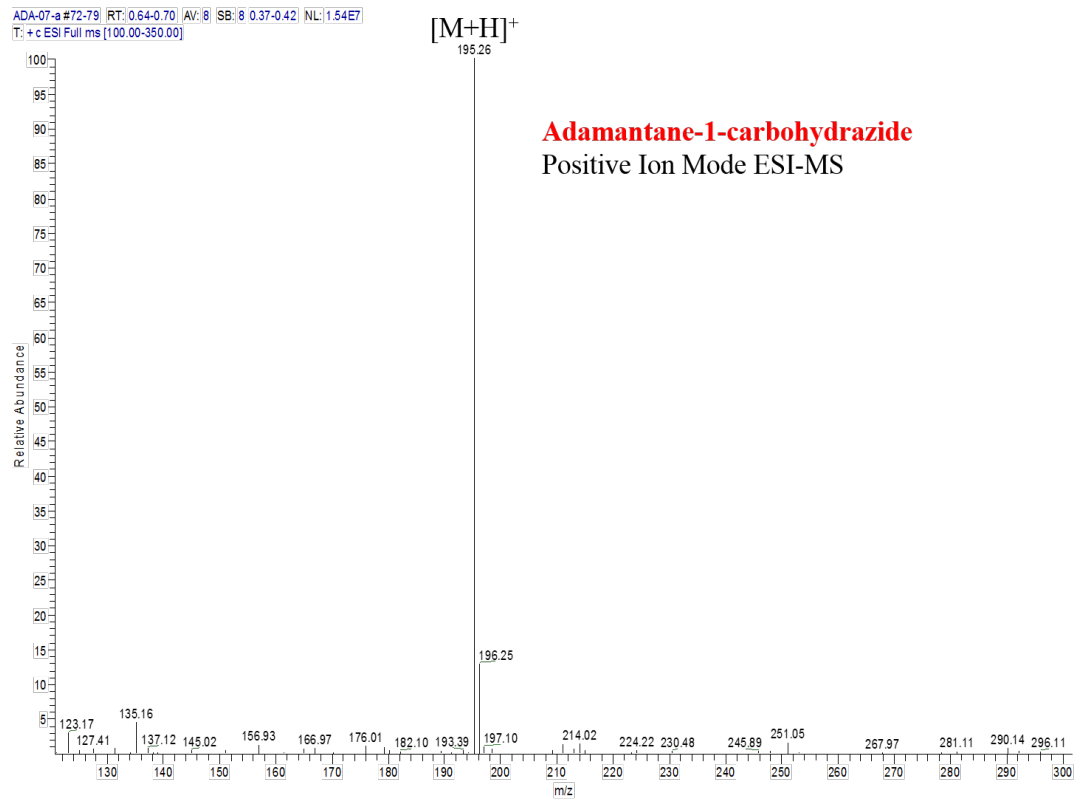

Figure S157: ESI MS of Adamantane-1-carbohydrazide

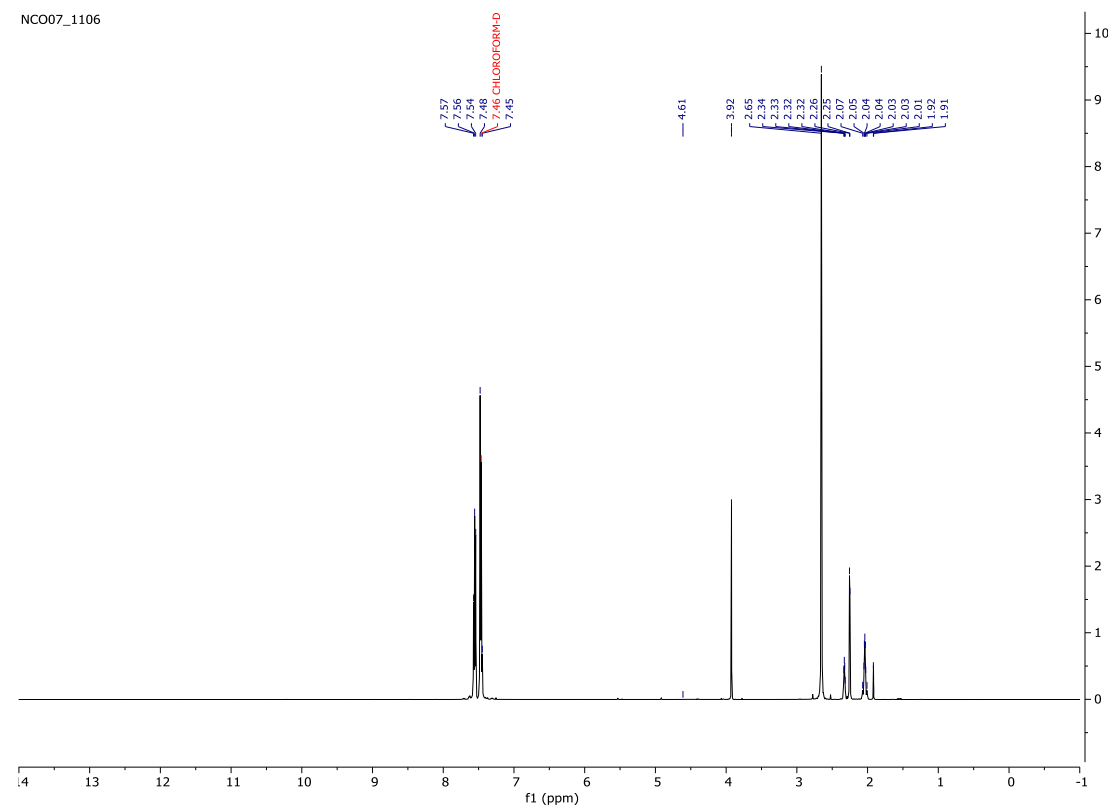

Figure S158: H NMR of 1-adamantane isocyanate 


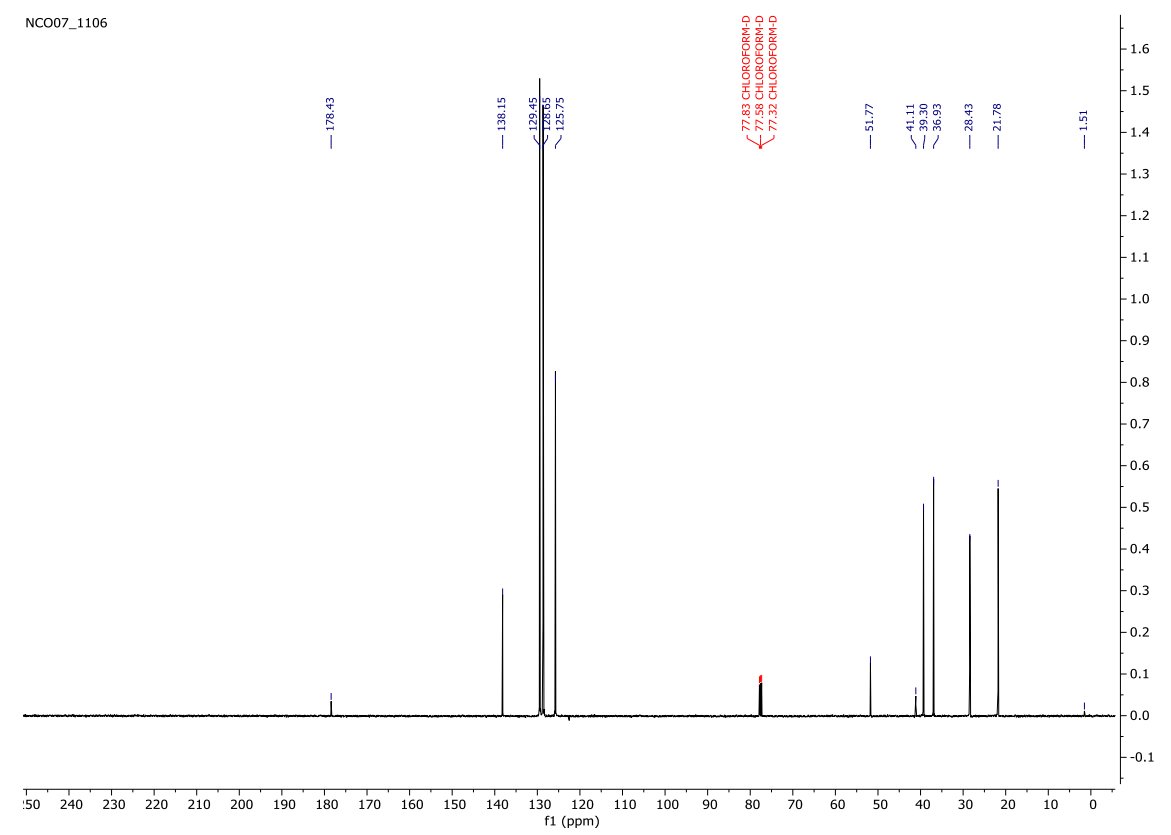

Figure S159: C NMR of 1-adamantane isocyanate

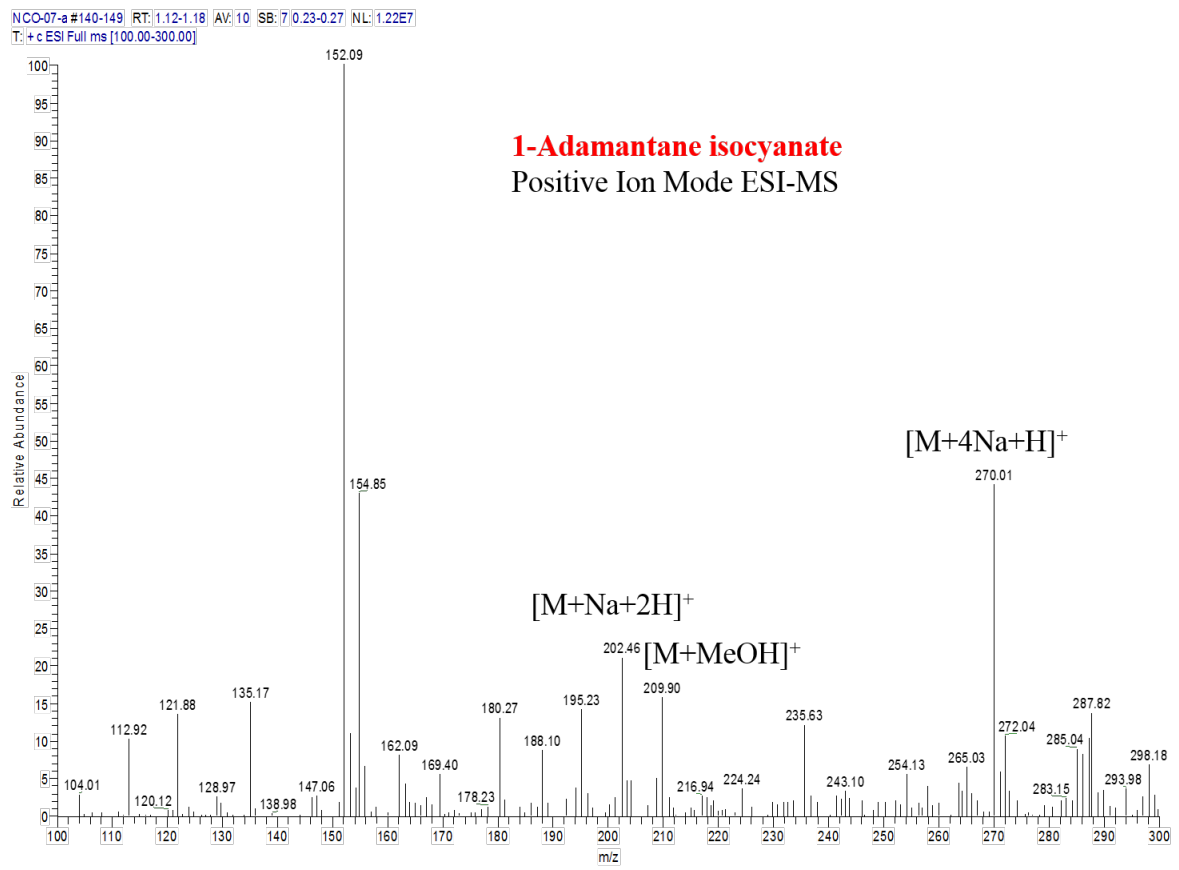

Figure S160: ESI MS of 1-adamantane isocyanate 


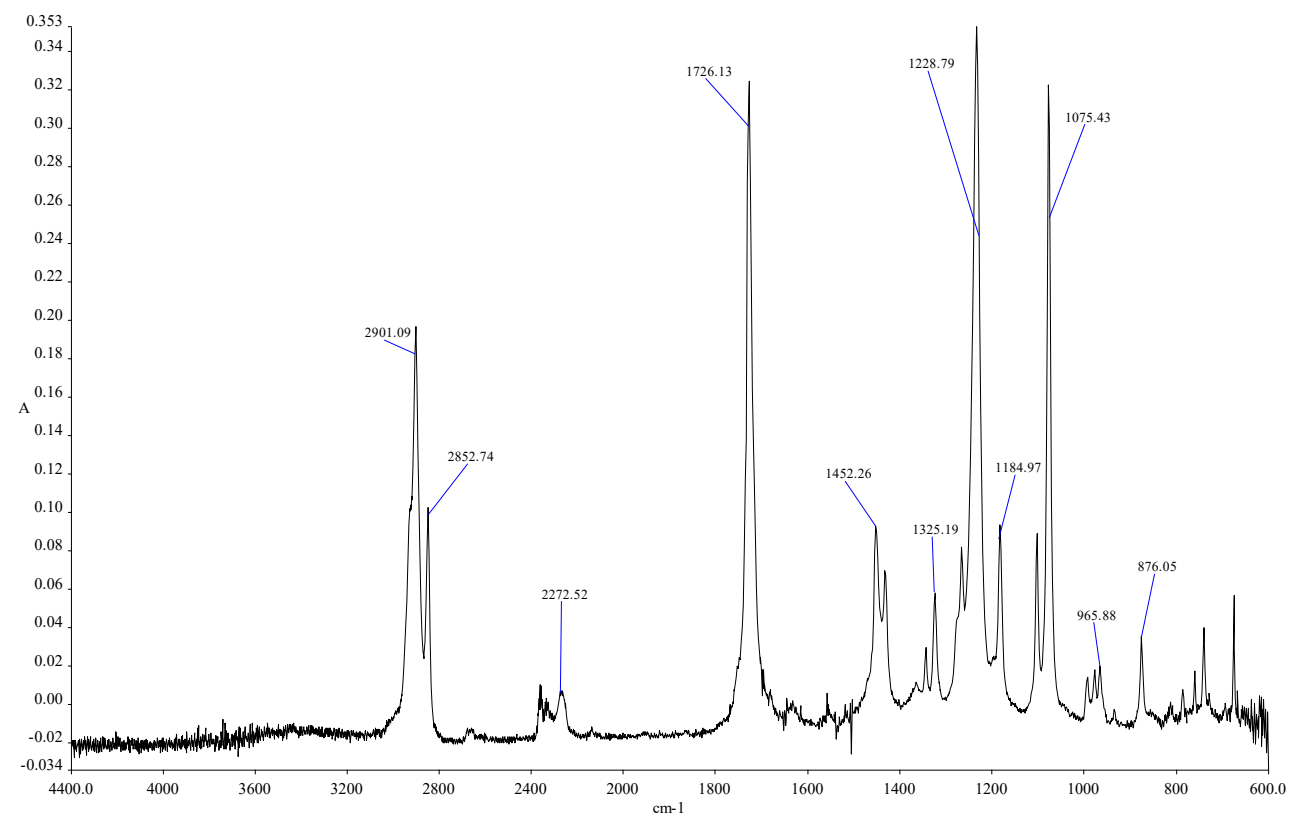

Figure S161: FT IR of 1-adamantane isocyanate

\section{References}

(1) Britton, J.; Jamison, T. F. The assembly and use of continuous flow systems for chemical synthesis. Nat. Protoc. 2017, 12, 2423-2447.

(2) Dhanya, R. P.; Herath, A.; Sheffler, D. J.; Cosford, N. D. P. A combination of flow and batch mode processes for the efficient preparation of $\mathrm{mGlu} 2 / 3$ receptor negative allosteric modulators (NAMs). Tetrahedron 2018, 74, 3165-3170.

(3) Herath, A.; Cosford, N. D. P. Continuous-flow synthesis of highly functionalized imidazooxadiazoles facilitated by microfluidic extraction. Beilstein J. Org. Chem. 2017, 13, 239-246.

(4) Hai, T. A. P.; Neelakantan, N.; Tessman, M.; Sherman, S. D.; Griffin, G.; Pomeroy, R.; Mayfield, S. P.; Burkart, M. D. Flexible polyurethanes, renewable fuels, and flavorings from a microalgae oil waste stream. Green Chem. 2020, 10.1039/d0gc00852d.

(5) Al-Amiery, A. A.; Kassim, F. A. B.; Kadhum, A. A. H.; Mohamad, A. B. Synthesis and characterization of a novel eco-friendly corrosion inhibition for mild steel in $1 \mathrm{M}$ hydrochloric acid. Scientific Reports 2016, 6, 19890.

(6) Poolman, J. M.; Maity, C.; Boekhoven, J.; Mee, L. v. d.; Sage, V. A. A. 1.; Groenewold, G. J. M.; Kasteren, S. I. v.; Versluis, F.; Esch, J. H. v.; Eelkema, R. A toolbox for controlling the properties and functionalisation of hydrazone-based supramolecular hydrogels. J. Mater. Chem. B 2016, 4, 852-859.

(7) Cougnon, F. B. L.; Caprice, K.; Pupier, M.; Bauzá, A.; Frontera, A. A Strategy to Synthesize Molecular Knots and Links Using the Hydrophobic Effect. J. Am. Chem. Soc. 2018, 140, 1244212450.

(8) Cochran, B. M. One-Pot Oxidative Cleavage of Olefins to Synthesize Carboxylic Acids by a Telescoped Ozonolysis-Oxidation Process. Synlett 2016, 27, 245-248.

(9) Datoussaida, Y.; Othmana, A. A.; Kirsch, G. Synthesis and Antibacterial Activity of some 5,5'-(1,4-phenylene)-bis-1,3,4-Oxadiazole and bis-1,2,4-Triazole Derivatives as Precursors of New SNucleosides. S. Afr. J. Chem. 2012, 65, 30-35. 